\begin{abstract}
UNIVERSIDADE DE SÃO PAULO
FACULDADE DE FILOSOFIA, LETRAS E CIÊNCIAS HUMANAS DEPARTAMENTO DE GEOGRAFIA

PROGRAMA DE PÓS-GRADUAÇÃO EM GEOGRAFIA HUMANA
\end{abstract}

\title{
A NOVA PROPOSTA CURRICULAR DO ENSINO DE GEOGRAFIA NA REDE ESTADUAL DE SÃO PAULO: UM ESTUDO
}

MURILO ROSSI 


\section{UNIVERSIDADE DE SÃO PAULO \\ FACULDADE DE FILOSOFIA, LETRAS E CIÊNCIAS HUMANAS DEPARTAMENTO DE GEOGRAFIA \\ PROGRAMA DE PÓS-GRADUAÇÃO EM GEOGRAFIA HUMANA}

\section{A NOVA PROPOSTA CURRICULAR DO ENSINO DE GEOGRAFIA NA REDE ESTADUAL DE SÃO PAULO: UM ESTUDO}

MURILO ROSSI

Dissertação de mestrado apresentada ao

Programa de Pós-Graduação da

Faculdade de Filosofia, Letras e Ciências Humanas da USP, na área de Geografia Humana, como requisito final para obtenção do título de Mestre em Geografia.

Orientador: Professor $\mathrm{Dr}^{\circ}$ Manoel Fernandes Sousa Neto 
UNIVERSIDADE DE SÃO PAULO FACULDADE DE FILOSOFIA, LETRAS E CIÊNCIAS HUMANAS DEPARTAMENTO DE GEOGRAFIA PROGRAMA DE PÓS GRADUAÇÃO EM GEOGRAFIA HUMANA

\author{
A NOVA PROPOSTA CURRICULAR DO ENSINO DE \\ GEOGRAFIA NA REDE ESTADUAL DE SÃO PAULO: UM \\ ESTUDO
}

\title{
MURILO ROSSI
}

Dissertação de mestrado apresentada ao Programa de Pós-Graduação da Faculdade de Filosofia, Letras e Ciências Humanas da USP, na área de Geografia Humana, como requisito final para obtenção do título de Mestre em Geografia.

BANCA EXAMINADORA:

Profo $^{\circ}$ Dr. Manoel Fernandes de Sousa Neto (orientador)

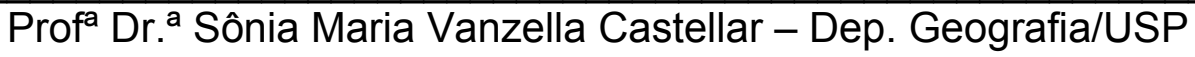

Prof ${ }^{\mathrm{D}}$ D. ${ }^{\circ}$ Charlles da França Antunes - Dep. Geografia/UERJ

São Paulo

2011 
AUTORIZO A REPRODUÇÃO E DIVULGAÇÃO TOTAL OU PARCIAL DESTE TRABALHO, POR QUALQUER MEIO CONVENCIONAL OU ELETRÔNICO, PARA FINS DE ESTUDO E PESQUISA, DESDE QUE CITADA A FONTE.

Catalogação da Publicação

Serviço de Documentação

Faculdade de Filosofia, Letras e Ciências Humanas da Universidade de São Paulo

Rossi, Murilo

A nova proposta curricular do ensino de Geografia na rede estadual de São Paulo: um estudo / Murilo Rossi; Orientador: Manoel Fernandes de Sousa Neto São Paulo, 2011.

$203 \mathrm{f}$.

Dissertação (Mestrado) - Programa de Pós-Graduação em Geografia Humana. Faculdade de Filosofia, Letras e Ciências Humanas.

1.Currículo. 2. Currículo de Geografia. 3. Ensino de Geografia.

4. Neoliberalismo. 5. Banco Mundial 


\section{AGRADECIMENTOS}

À Universidade de São Paulo e ao Departamento de Geografia - realmente a minha segunda casa.

A todos meus amigos e amigas que, direta ou indiretamente, contribuíram para esse trabalho (presencialmente ou virtualmente).

Ao meu orientador Manoel Fernandes que me deu essa oportunidade e, acima de tudo, acreditou em mim. Obrigado pela paciência, compreensão e carinho.

A querida e amiga professora Sônia Castellar. Sônia, você me acolheu e me deu oportunidade de acreditar num mundo mais justo e, acima de tudo, acreditar em minhas potencialidades. Muito obrigado.

A meu pai que, mesmo em situações adversas, sempre me incentivou aos estudos.

Ao sempre e guerreiro irmão Angelo Rossi, por seu companheirismo, apoio e por sua incessante busca pela felicidade.

As queridas Anna Flávia e Júlia Gomes. Sempre me incentivaram. Valeu mesmo!!!!

A minha querida e amada amiga Daniela Thozzi, que sempre esteve ao meu lado em todos os momentos. I love you!!!!!!

Aos meus amigos Marcio Lima, Eduardo Miyamoto e Sandro Fogaça. Eternamente amigos!!!!!

A todo pessoal do Laboratório de ensino de geografia da Faculdade de Educação. Vocês são dez!!!!!

Ao amigo Marcus Mastrandéa por corrigir o texto, mesmo sendo de última hora.

A Doutora Didimar Façanha. Tu és uma segunda mãe para mim. Obrigado por tudo.

E para minha querida companheira Teresa Salles. Só você sabe o que eu passei nesses 3 anos querida. Metade dos nossos 6 anos. Obrigado por tudo. Tê, eu consegui!!!!!!!!!!!!!!!!!!!

Mamãe Vera: onde estiver, tenho certeza que está feliz!!!!

E finalmente um agradecimento a seres que não vão entender, mas que foram fundamentais para mim: meus três gatos. Companheiros como vocês não existem em nenhum lugar. 
Escrevo fazendo um apelo para que se possa fazer qualquer coisa no sentido de melhorar a educação brasileira. Para isso, é urgente que se respeitem professores e professoras. E uma das condições de respeito é pagar bem, ou menos imoralmente. A outra condição é acreditar.

Paulo Freire 
ROSSI, M. A nova proposta curricular do ensino de geografia na rede estadual de São Paulo: um estudo. 2011. ? f. Dissertação (Mestrado) - Faculdade de Filosofia, Letras e Ciências Humanas. Departamento de Geografia, Universidade de São Paulo, São Paulo, 2011.

\section{RESUMO}

Este trabalho consiste numa análise do currículo de geografia vigente para o ensino fundamental II no estado de São Paulo, com o objetivo de refletir sobre a construção da geografia escolar inserida no documento da "Proposta Curricular do Estado de São Paulo". A pesquisa foi direcionada para uma investigação do currículo de geografia, contextualizado nas transformações na educação brasileira e paulista, dentro de uma perspectiva neoliberal. Com isso, foi feita uma análise das teorias curriculares, dentro de um debate que incluiu as diversas concepções de currículo, da geografia e seu ensino, objetivando compreender a perspectiva teórico-metodológica inserida no documento, além da compreensão de sua gênese e as implicações contidas no processo político-educativo em relação a esse novo currículo. A partir dessa proposta, observamos que o ensino de geografia é imposto as comunidades escolares, com concepções contraditórias, voltadas para uma educação orientada por organismos multilaterais como o Banco Mundial, trazendo um ensino e aprendizagem baseados no indivíduo, numa perspectiva empresarial de educação, ocultando e descaracterizando fundamentos essenciais para uma organização curricular que valorize ações que privilegiem realmente o papel do homem como sujeito histórico.

Palavras chaves: Currículo, Currículo de Geografia, Ensino de Geografia, Neoliberalismo, Banco Mundial. 
ROSSI, M. A nova proposta curricular do ensino de geografia na rede estadual de São Paulo: um estudo. 2011. ? f. Dissertação (Mestrado) - Faculdade de Filosofia, Letras e Ciências Humanas. Departamento de Geografia, Universidade de São Paulo, São Paulo, 2011.

\begin{abstract}
This work is an analysis of the current geography curriculum for Basic School in São Paulo state, in order to reflect on the construction of school geography included in the document "Proposta Curricular do Estado São Paulo." The research has directed towards an investigation of the geography curriculum, contextual changes in education in Brazil and Sao Paulo within a neoliberal perspective. With this, an analysis of curriculum theories, in a debate which included the various conceptions of curriculum, and teaching of geography in order to understand the theoretical-methodological inserted into the document, beyond the understanding of its genesis and implications contained political-educational process in relation to this new curriculum. On this basis, we've observed that the teaching of geography is imposed school communities, with contradictory views, facing an education guided by multilateral agencies like the World Bank, bringing a teaching and learning based on individual education from a business perspective, hiding and characterizing the essential foundations for a curriculum that values actions that actually favor the role of man as a historical subject.
\end{abstract}

Keywords: Curriculum, Curriculum Geography, Teaching Geography, Neoliberalism, World Bank. 


\section{LISTA DE SIGLAS}

AGB - Associação dos Geógrafos Brasileiros

CEE - Conselho Estadual de Educação

CENP - Coordenadoria de Estudos e Normas Pedagógicas

CENPEC - Centro de Estudos e Pesquisas em Educação, Cultura e Ação Comunitária

DCN - Diretrizes Curriculares Nacionais

DE - Diretoria de Ensino

DEM - Democratas

EJA - Educação de Jovens e Adultos

ENEM - Exame Nacional do Ensino Médio

ETEC - Escola Técnica Estadual Centro Paula Souza

FDE - Fundação para o Desenvolvimento da Educação

FHC - Fernando Henrique Cardoso

FIPE - Fundação Instituto de Pesquisas Econômicas

FMI - Fundo Monetário Internacional

FUNDEF - Fundo Nacional de Desenvolvimento da Educação Fundamental

INEP - Instituto Nacional de Estudos e Pesquisas Educacionais

LDB - Lei de Diretrizes e Bases da Educação

MEC - Ministério da Educação

ONG - Organização Não Governamental

PCN - Parâmetros Curriculares Nacionais

PCP - Professor Coordenador Pedagógico 
PNLD - Programa Nacional do Livro Didático

PSDB - Partido da Social Democracia Brasileira

SAEB - Sistema Nacional de Avaliação da Escola Básica

SARESP - Sistema de Avaliação de Rendimento Escolar do estado de São Paulo

SEE-SP - Secretaria de Estado da Educação de São Paulo

UNESCO - Organização das Nações Unidas para a Educação, a Ciência e a Cultura

UNESP - Universidade Estadual Paulista

UNICAMP - Universidade Estadual de Campinas

USP - Universidade de São Paulo 


\section{LISTA DE QUADROS}

Quadro 1 - Distribuição setorial dos empréstimos do Banco Mundial ao Brasil.....

Quadro 2 - Participação setorial dos empréstimos aprovados pelo Banco Mundial para o Brasil - 1987-1994. 35

Quadro 3 - As quatro maiores e as quatro menores redes estaduais de ensino público do Brasil (2010). 69

Quadro 4 - Matriz de referência para avaliação de rendimento do SARESP - $6^{\text {a }}$ série do ensino fundamental II (2009). 106

Quadro 5 - Proposta de níveis de compreensão dos alunos esperados pelos professores 128

Quadro 6 - Proposta de avaliação e dos objetivos atingidos com a execução das atividades pelos alunos 


\section{SUMÁRIO}

I - Introdução

15

\section{Capítulo 1}

1. Contextualizando o Plano de Dez Metas para a Educação da SEE-SP por dentro das reformas neoliberais

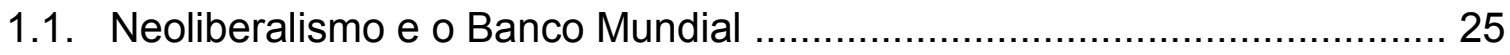

1.2. Neoliberalismo e as políticas do Banco Mundial para a educação 29

1.3. Neoliberalismo e a educação no Brasil e no estado de São Paulo 33

1.4. Contextualização do Plano de Dez Metas para a Educação do governo do estado de São Paulo

1.5. O Plano de Dez Metas para a Educação e a proposta curricular do estado de São Paulo

\section{Capítulo 2}

2. As Teorias Curriculares e os Currículos de Geografia

2.1. Uma introdução ao estudo do currículo

2.2. Teorias tradicionais e críticas sobre currículo 49

2.3. Currículos tradicionais e currículos críticos de Geografia 51 
2.3.1. As transformações nos currículos de Geografia 55

2.3.2. Os conteúdos e práticas curriculares de Geografia. 57

2.3.3. Relações na transformação da realidade do ensino público básico de Geografia 60

\section{Capítulo 3}

3. A organização da proposta curricular de ensino da rede estadual de São Paulo 66

3.1. Um panorama da rede estadual de ensino de São Paulo 68

3.2. Apresentando a proposta curricular da rede estadual de São Paulo 73

3.2.1. Reorientação curricular dos ensinos Fundamental e Médio - Grade Curricular 87

3.2.2. Concepções organizacionais de implementação do currículo .90

3.2.3. Matrizes de referência para avaliação - SARESP - documento básico 102

3.2.4. Materiais suplementares a implementação da proposta curricular 110

3.3. Uma análise da Geografia no currículo da rede estadual de ensino de São

Paulo 111

3.3.1. Os Parâmetros Curriculares Nacionais, a Geografia e a Proposta Curricular do Estado de São Paulo. 
3.3.2. Ensino e Aprendizagem em Geografia: conteúdos

3.3.3. Metodologia e Práticas em Geografia: as cartilhas

didáticas

3.3.3. O projeto político no currículo de Geografia: neoliberalismo e docência.

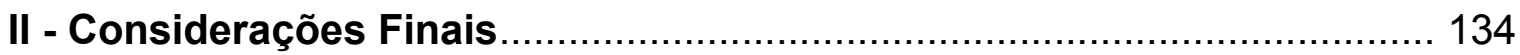

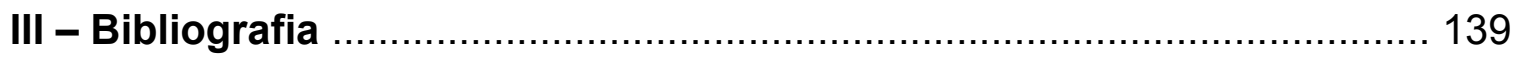

IV - Anexo A 


\section{I - INTRODUÇÃO}

Esse trabalho foi produzido em decorrência de questionamentos em relação à nova implementação curricular da rede estadual de ensino de São Paulo em 2007, durante o governo de José Serra (2006-2010). Esse currículo é parte de uma política pública para a educação em nosso estado, que gerou um debate no meio acadêmico, escolar e sindical.

Em decorrência disso, houve um estímulo pessoal em tecer análises sobre tais reformas, tentando expor seus reais objetivos, assim como os métodos e ações pertinentes ao desenvolvimento educacional da rede pública de nosso estado.

O início dessas reformas se dá por intermédio de uma política de avaliações externas, já desenvolvidas até então, mas otimizada a partir de 2007 para a implementação de um novo currículo na rede. Sendo denominado Sistema de Avaliação de Rendimento Escolar do estado de São Paulo (SARESP), essa avaliação do desempenho escolar de alunos se lançou com uma pretensão um tanto ousada. Como foco central de sua proposta, podemos destacar um subsidio a definição e as ações políticas para a melhoria da qualidade da educação, gerando um balanço do desempenho escolar dos alunos, apontando para as competências bem desenvolvidas e detectando aquelas que deveriam tornar-se objetos de ações pedagógicas específicas.

Com isso, o diagnóstico das escolas foi feito analisando prioritariamente as disciplinas matemática e língua portuguesa, pois, no atual currículo, é privilegiado o domínio da escrita e da leitura, assim como as operações matemáticas. Outras formas de avaliação externa são feitas na rede como o Sistema Nacional de Avaliação da Escola Básica (SAEB) e o Exame Nacional do Ensino Médio (ENEM), onde é esperada uma compatibilidade de diagnósticos em seus diferentes momentos de aplicação e avaliação dos resultados.

Tais avaliações, assim como o SARESP, privilegiam o ensino e aprendizagem baseados em competências e habilidades. Portanto, temos um quadro de ações diagnósticas que se sustentam em construção e interpretação de dados e tabelas. $E$ 
isso é uma política que, passo a passo, vem se afastando das realidades das escolas. As políticas que serão discutidas mais amiúde são implementadas nas escolas à revelia dos professores e estão distantes da realidade.

Os resultados se transformam em metas e o corpo administrativo da escola se torna demasiadamente central, no que condiz a implementação de tais políticas. $O$ professor se torna mero agente de reprodução de ordens e conhecimentos.

Com isso, é aberto um caminho para a implementação do novo currículo através de diagnósticos quantitativos e qualitativos sobre a educação no estado, refletido numa série de decretos e documentos que institucionalizam tais práticas curriculares.

Historicamente, essa política vem se arrastando ao longo da década de 1990 com duas gestões do governo Fernando Henrique Cardoso e de seu partido no governo do estado de São Paulo.

Nesse período, a educação brasileira e paulista passavam por transformações que pautavam em reformas curriculares e novas avaliações para os níveis de ensino fundamental, médio e superior. Ferreira (2009) afirma que tais reformas foram intensas e significativas nesse período e provocaram mudanças no campo institucional e na legislação, com destaque para criação da Lei de Diretrizes e Bases da Educação (LDB/9.394/96), dos Parâmetros Curriculares Nacionais (PCNs) para o ensino fundamental (1997 - primeiro e segundo ciclos, 1998 - terceiro ciclo e médio) e orientações curriculares de 2004 e 2006 para o ensino médio.

A criação da nova LDB/96 trouxe uma transformação estrutural da educação básica como um todo, onde, ainda nesse período, não só o Brasil, mas toda América Latina estava atrelada a determinações de órgãos representativos dos países centrais como o Banco Mundial. Essas determinações ocorrem não somente na esfera da educação, mas também nas esferas econômica e política.

Essa política "nova" na educação brasileira criou um estigma onde a escola brasileira era tida como fracassada e ineficiente. E que esse "novo" seria o ideal para tal momento histórico. A justificativa para tais iniciativas eram sempre o discurso da necessidade de tais reformas, já que vivíamos novos tempos. Estabeleceu-se assim a relação onde o velho era atrasado e o novo moderno, mas sem uma avaliação ou 
mesmo participação das várias vertentes da sociedade na aceitação ou não de tais prerrogativas.

Com as reformas curriculares, um objetivo central seria definir novos parâmetros para a educação brasileira. Uma educação que fosse menos fragmentada e disciplinar e mais integrada e interdisciplinar. A construção dos PCNs teve como norte contribuir com a centralidade das reformas educacionais, pois seria através deles que os sistemas de avaliação, como o SAEB e mesmo o SARESP juntamente com os programas de avaliação de livros didáticos se desenvolveriam.

É neste contexto de transformações do mundo da educação, que no Brasil ocorrem às reformas curriculares e a implantação dos sistemas de avaliação. No estado de São Paulo com a implementação do novo currículo, simultaneamente às transformações impostas pelo neoliberalismo na economia brasileira, no ano de 2007 a SEE-SP (Secretaria de Estado da Educação do estado de São Paulo) apresentou a todas as escolas da rede, assim como para a imprensa, os procedimentos legais para a implantação desse currículo.

No documento, intitulado "Proposta Curricular do estado de São Paulo", a autonomia da escola está sendo colocada com premissas como o "aprender a aprender", "aprender a fazer e conviver", além de construção de identidade, pertencimento, responsabilidade, o que universaliza a escola e a relevância da aprendizagem. Sendo assim, elencados os quatro pilares da educação, o currículo deverá ser articulado com a escola como espaço de cultura, utilizando como eixo às competências de aprendizagem voltadas para a leitura e a escrita, além da contextualização para o mundo do trabalho.

Com isso, algumas questões são de fundamental compreensão: $\mathrm{E}$ a autonomia de ensinar com condições dignas de trabalho? Autonomia é simplesmente "jogar" a responsabilidade no indivíduo, excluindo o estado de suas atribuições? Quais as intencionalidades propostas em tal currículo? Os objetivos de aprendizagem são realmente voltados para o mundo do trabalho? Não existem outros caminhos? 
Como objetivo central dessa proposta, temos a melhoria da qualidade do ensino e aprendizagem dos alunos ${ }^{1}$. Mas como seriam essas ações? Segundo a proposta curricular, seriam mobilizados principalmente os corpos administrativos e pedagógicos das escolas, como os diretores, vice-diretores e professores coordenadores.

Com isso, há a percepção de uma relação de implementação curricular participação democrática não real, desqualificando o trabalho docente e a construção coletiva de uma estrutura curricular viável e acordado entre os atores educacionais de uma dada escola.

Os administradores escolares teriam toda a formação e apresentação contextualizada das ações esperadas para implementação, centralizados exclusivamente neles, e os professores e outros funcionários, portanto, deveriam obedecer e cumprir, eximindo o Estado de toda sua responsabilidade na formação docente.

Sendo assim, os professores continuariam a exercer suas profissões como meros reprodutores de conteúdos, utilizando material didático próprio da rede, obtendo aperfeiçoamentos esporádicos com os administradores escolares e seguindo a premissa do "aprender a aprender" expressa no currículo.

Essas são algumas situações que demonstram a complexidade de uma nova organização curricular, numa rede que concentra mais de 4500 escolas, com mais de 5 milhões de alunos.

Nosso objetivo então é fazer uma análise do documento intitulado Proposta Curricular do estado de São Paulo, a luz das transformações neoliberais na educação no Brasil, refletindo o ensino de geografia inserida neste documento.

Esse é o princípio norteador de análise da pesquisa, com um estudo sobre tal proposta curricular, como um componente central de ordem institucional, que faz parte de um projeto político que visa mudanças na rede estadual de ensino de São Paulo. Como estrutura de pesquisa, devemos analisar também até que ponto esse currículo possui ligação com o conjunto de transformações sofridas na educação brasileira.

\footnotetext{
1 São Paulo. Proposta curricular para o ensino de Geografia. Ensino fundamental e médio.
} Secretaria Estadual de Educação. CENP. São Paulo, 2007 (pp 08) 
Não se trata de afirmar que o estado não deva construir políticas públicas, principalmente para a educação, ou no caso do currículo, que o mesmo não deva construir uma política curricular. Mas sim como essa proposta curricular foi construída sem participação efetiva dos professores, de forma centralizada e vertical. E mais do que isso: trata-se de saber quais as finalidades políticas dessas proposições, já que o currículo é território em disputa.

Também não se trata de um democratismo, mas de entender que um processo de construção coletiva acerca do tema, também é um espaço de formação dos profissionais envolvidos no processo educacional e que a conseqüência disto é a melhoria da qualidade da educação pública.

O ensino de geografia é um outro ponto relevante para a pesquisa, onde essas reformas curriculares trazem questionamentos significativos para um debate mais amplo: o que devemos ensinar aos alunos? Por que devemos ensinar tais conteúdos geográficos e outros não? Há intencionalidades na seleção de conteúdos geográficos?

Com isso, lançamos das ideias pertinentes de Ferreira (2009:18):

A Geografia brasileira, no percurso de sua trajetória desde o seu processo de institucionalização, passando pelo processo de renovação nos anos de 1980 até os dias atuais passou por transformações significativas, mudanças de caráter teórico-metodológico debatidos na academia e que chegaram à escola por intermédio de novos textos, programas curriculares e livros didáticos. Nesse sentido, cabe responder a outras indagações nesta pesquisa: Quais são as marcas da seara geográfica que este currículo carrega? Qual(is) concepção(ões) teórico-metodológica(s) estão presentes e reificada(s) neste documento?

É nesse caminho que construímos a análise do documento da Proposta Curricular. A opção pela análise documental e bibliográfica seria por entender que seja pertinente existirem meios para definir, resolver, não somente problemas conhecidos, como também explorar novas áreas e enfoques, onde os problemas ainda não se cristalizaram suficientemente segundo Lakatos \& Marconi (1983)

Em Ludke \& André (1986), é colocado à importância e as vantagens de se pesquisar com o uso de documentos na pesquisa educacional. Os documentos são considerados uma fonte estável e rica de pesquisa, pois persistem ao longo do tempo, 
podendo ser consultados quantas vezes for necessário para a obtenção de dados e que dão mais estabilidade aos resultados obtidos na investigação.

É importante considerar o documento da Proposta Curricular como uma fonte primária de informação, onde, para uma melhor compreensão acerca do tema, deverá estar associado a outros documentos - como o SARESP e os Cadernos didáticos dos alunos e professores.

Sabendo das escolhas metodológicas de pesquisa, juntamente com seu objetivo central de análise, o presente trabalho se dividirá em três capítulos.

No primeiro delimitamos o tema reformas neoliberais para a educação e o Plano de dez metas para a educação da SEE-SP. Dessa forma, nesse capítulo analisaremos o contexto da implementação de políticas educacionais no mundo e no Brasil, a partir da década de 1990, compreendendo seu corte neoliberal.

Como objetivo mais específico, há a necessidade de correlacionar tais planos as reformas neoliberais para a educação, sempre com o enfoque na proposta curricular e seus desdobramentos em relação à geografia. Esse novo currículo de São Paulo não se encontra isolado de um novo contexto sócio-espacial e de concepção de mundo. Então é inerente uma análise de suas intencionalidades e seus pontos de convergência para a realidade das escolas.

No segundo capítulo, há uma necessidade de se analisar as teorias curriculares e o currículo de geografia. É nesse momento que buscamos a compreensão do contexto da implementação dessas políticas neoliberais no estado de São Paulo, que levou a cabo a deterioração da escola pública, do trabalho docente e da formação dos estudantes, ao impor uma autonomia, um currículo e processos avaliativos, a partir da lógica do mercado.

Nosso objetivo neste capítulo é contextualizar a geografia impressa no documento de Implementação Curricular da SEE-SP na trajetória que constroem os currículos da geografia na escola.

O terceiro capítulo visa o estudo do documento curricular em si, retornando e dialogando com os capítulos anteriores. 
Com isso, torna-se necessário contextualizar o currículo de geografia que impõe um viés epistemológico eclético e pós-moderno, muitas vezes vulgarizando substantivamente um autor e que está de mãos dadas com uma perspectiva neoliberal.

O risco de se fazer uma análise tão complexa das reformas na educação no Brasil e no estado de São Paulo, assim como sua política curricular do ensino de geografia, é muito grande. Risco esse de cair na generalização dos fatos, principalmente pelo método escolhido.

Mas sem dúvida a riqueza dos fatos, concentrada na realidade empírica e teórica do estudo dos currículos, começa realmente por uma análise bibliográfica e documental. Passo a passo, dentro do movimento da pesquisa, há de se ter uma contribuição para uma ampliação dos conhecimentos sobre o assunto, proporcionando uma sistematização epistemológica bastante interessante para o estudo do tema tratado.

Analisar a geografia dentro da Implementação Curricular da SEE-SP é nossa proposta. O currículo tem de ser visto muito além de uma grade curricular, com seus conteúdos e disciplinas a serem ministrados nas aulas.

Este é nosso propósito dissertativo. Esse é nosso caminho. 


\section{CAPÍTULO 1}

\section{Contextualizando o Plano de Dez Metas para a Educação da SEE-SP por dentro das reformas neoliberais}

A proposta de Implementação Curricular do governo do estado de São Paulo para as escolas públicas é fruto de um processo histórico, que consiste em reformas no plano federal e estadual. Toda proposta de reforma não se faz sem objetivos claros e definidos. Diz também que toda proposta de reforma educacional se faz com o objetivo de mudar a escola; e essa escola não está desconectada das mudanças que o mundo sofre.

A escola, de fato, está longe de ser o que poderia, de dar o contributo social de formar para o mundo, mas isso não implica em formar para o mundo na lógica de reprodução ampliada do capital.

Gonçalves (1999) afirma que identificar a concepção do mundo adjacente às propostas de reforma no mundo da educação, que vem nos sendo (im)postas nos dias que correm, é essencial e, mais do que isso, mostrar em que terrenos elas emergem para que tentemos identificar os sujeitos que através delas vêm tentando (im)por o seu mundo.

As transformações no mundo da educação, assim como no mundo do trabalho, estão conectadas com as transformações que o capitalismo sofre historicamente. Tais transformações, no caso do Brasil e toda América Latina, são de caráter neoliberal. Pautados numa nova forma dos Estados intervirem nos processos políticos e econômicos, as reformas educacionais acontecem de uma forma imposta pelos governos, fruto de orientações fechadas em acordos internacionais com instituições e organismos multilaterais.

Há com isso uma crescente subordinação dos Estados Nacionais às exigências de organismos internacionais como a UNESCO (Organização das Nações Unidas para 
a Educação, a Ciência e a Cultura), o Banco Mundial e o BID (Banco Interamericano de Desenvolvimento).

Com isso, as políticas curriculares propostas nesse novo momento (a partir da década de 1990) estão inter-relacionadas com tais diretrizes, onde o Banco Mundial ${ }^{2}$ passa a financiar inúmeros projetos de reforma educativa no mundo todo, como afirma Leher (1998). O debate fica em torno do que ensinar, para quê ensinar, alinhadas a seleção de conteúdos e disciplinas. Embora elas sejam impostas por tais diretrizes, são intencionalizadas com a aquiescência dos dirigentes em nível nacional e, logo, há um tanto de subordinação por parte das frações da burguesia nacional.

Segundo Ferreira (2009), todas essas reformas educacionais apresentam dois pilares que irão orientar os novos rumos da educação brasileira: novos currículos, diretrizes curriculares e novas formas de avaliação. Indaga ainda que o único propósito disso é implantar um novo modelo de educação com vista a uma nova forma de organização e gestão do mundo do trabalho, influenciadas pelos modelos de produção flexível.

Gentili (1995) afirma que dois motivos são fundamentais para o interesse neoliberal na educação: um deles é que a cartilha neoliberal é uma demonstração bastante didática do discurso liberal, que atribui a intervenção do estado e à esfera pública todos os males sociais e econômicos de nossa atual situação; e à livre iniciativa todas as virtudes que podem conduzir à regeneração e recuperação da democracia, da economia e da sociedade.

Em segundo lugar, ainda em Gentili (1995), está o caráter da cartilha do Instituto Liberal $^{3}$, que demonstra o papel estratégico da educação nos projetos Neoliberais, com vistas a servir os propósitos empresariais e industriais, com duas dimensões principais:

\footnotetext{
${ }^{2}$ Antes da mudança estratégica de diretrizes do Banco Mundial, iniciado com o começo da gestão McNamara (19681981), e realmente implementado nos ditos países subdesenvolvidos após as aberturas democráticas, Soares (2007:20,21) afirma: "Nos anos 80, a eclosão da crise de endividamento abriu espaço para uma ampla transformação do papel até então desempenhado pelo Banco Mundial e pelo conjunto de organismos multilaterais de financiamento. Estes passaram a figurar como agentes centrais do gerenciamento das precárias relações de crédito internacional, e o Banco Mundial ganhou importância estratégica na reestruturação econômica dos países em desenvolvimento por meio dos programas de ajuste estrutural. De um banco de desenvolvimento, indutor de investimentos, o Banco Mundial tornou-se o guardião dos interesses dos grandes credores internacionais, responsável por assegurar o pagamento da dívida externa e por empreender a reestruturação e abertura dessas economias, adequando-as aos novos requisitos do capital globalizado".
}

${ }^{3}$ Ver Gentilli (1995) 
de um lado, como foco central, a reestruturação buscada pelos ideólogos neoliberais, atrelados à educação institucionalizada, com objetivos estreitos de preparação para o local de trabalho.

De outro lado, acreditam que utilizar a educação como veículo de transmissão das ideias que proclamam as excelências do livre mercado e da livre iniciativa é uma boa estratégia.

A partir dessas ideias neoliberalizantes, as reformas promovidas pelo governo federal nos últimos anos, e especialmente do governo estadual de São Paulo, proporcionaram uma maior flexibilidade curricular, com maior integração das disciplinas, capazes de formar habilidades e competências às necessidades dos novos processos produtivos.

Notadamente referido as reformas estaduais, o Plano de dez metas para a educação na rede estadual de ensino de São Paulo foi lançado em 2007 pelo até então governador José Serra, com a justificativa que a grande maioria dos estudantes já estão inseridos na rede pública, o objetivo, segundo a SEE-SP (Secretaria de Estado da Educação), é melhorar a qualidade de educação. O Estado planejou investimentos de $R \$ 1,7$ bilhão que devem ser divididos entre as 5.300 escolas estaduais. A média é de $R \$ 320$ mil por unidade ao longo dos três anos.

"A prioridade é a qualidade do ensino. Para isso, além de mudanças de abordagem e de incentivos, é preciso uma rede estruturada, modernizada. A escola precisa ser a segunda casa do aluno", afirma, com uma certa demagogia, a secretária de Estado da Educação na época, Maria Helena Guimarães de Castro. O problema está no que se considera qualidade. A qualidade é, uma vez mais, a medida do mercado. Expressa na lógica da produtividade, da quantidade de alunos que é promovida sem avaliação, onde esta serve aos fins definidos pelo Banco Mundial.

Além de afirmar que são metas, reproduzindo um termo que tem mais afinidade com o mundo do mercado, José Serra lança tal política que refletirá nas mudanças curriculares propostas nesse estudo, através da análise do documento de Implementação da Nova proposta Curricular. 
Com isso é de extrema necessidade, a partir de agora, analisar como o neoliberalismo direciona as reformas na educação brasileira, fazendo um contraponto com o documento de Implementação curricular do estado de São Paulo.

\subsection{Neoliberalismo e o Banco Mundial}

O neoliberalismo, enquanto doutrina político-econômica nasceu na Europa e América do Norte, após a Grande Guerra e foi uma reação teórica e política contra o Estado intervencionista do bem estar social. Essa doutrina foi fundada por um grupo de economistas, historiadores e filósofos acadêmicos para solucionar as mazelas do capitalismo, surgindo em 1947 com a fundação do Mont Pelerin Society, que leva o nome de um spa Suíço em que se reuniram pela primeira vez nomes notáveis como Ludwig Von Mises, Milton Friedman, Karl Popper e Friderich Von Hayek.

Para Perry Anderson (1995) as ideias neoliberais surgem como um ataque contra qualquer limitação dos mecanismos de mercado por parte do Estado, denunciadas como uma ameaça à liberdade econômica e política dos indivíduos. São políticas econômicas que propõe que o bem estar humano pode ser melhor promovido, liberando-se as liberdades e capacidades empreendedoras individuais no âmbito de uma estrutura institucional caracterizada por sólidos direitos a propriedade privada, livres mercados e livre comércio, como afirma Harvey (2008).

O neoliberalismo prima por um combate ao keynesianismo com objetivo de preparar as bases de um outro tipo de capitalismo, livre de regras estatizantes, cujo princípio é o livre mercado. Num primeiro momento, a base neoliberal será apenas teórica, pois "as bases que o sustentariam não haviam sido construídas" (Ferreira,2009:63)

Anderson (1995) e Harvey (2008) apontam que é com a chegada da crise de acumulação capitalista fordista em 1973, do keynesianismo à acumulação flexível (Escola de Regulação), fomentada pela crise do petróleo, que o neoliberalismo ganha 
um grande terreno para sua efetivação, com o fim dos trinta anos de ouro do capitalismo, que se estendem do fim da segunda guerra à década de 1970.

A crise em realidade se inicia em 1968 e tem pelo menos quatro pilares: 1) Recuperação da Alemanha e Japão, que se tornam concorrentes diretos da economia norte-americana; 2) Queda tendencial da taxa média de lucros em função da queda no consumo, o que leva às saídas que buscam propor não mais produção em larga escala, mas produção flexível, por demanda, e alteram o gerenciamento científico do trabalho com o ingresso do toyotismo; 3) Aumento da inflação e recessão, o que leva o Estado a realizar cortes de benefícios e a privatizar setores da economia antes estatizados, com vistas a bancar a remuneração do capital diante da baixa tendencial dos lucros; 4) Crise ambiental, em função do significativo aumento dos custos de produção derivados do uso de recursos "naturais" e, ainda, não esqueçamos, a revolução no campo da microeletrônica, química fina e física quântica, que alteram as dimensões do mundo e as formas de pensá-lo.

Nessa época, os países centrais do capitalismo entraram numa grande recessão que, pela primeira vez combinaram baixas taxas de crescimento com altas taxas de inflação e elevados índices de desemprego. A insatisfação foi geral, desde as classes mais abastadas como as mais privilegiadas;mas, como não poderia ser diferente, a classe trabalhadora foi a que mais sofreu as conseqüências desse processo.

Para os teóricos neoliberais, a causa dessa crise estava focada no aumento dos gastos sociais do Estado, nos sindicatos e no movimento operário, inviabilizando sua base de acumulação capitalista.

A alternativa neoliberal a essa crise foi exposta por Anderson:

Manter um estado forte, sim, em sua capacidade de romper com o poder dos sindicatos e no controle do dinheiro, mas parco em todos os gastos sociais e nas intervenções econômicas. A estabilidade monetária deveria ser a meta suprema de qualquer governo. Para isso seria necessária uma disciplina orçamentária, com a contenção dos gastos com o bem estar, e a restauração da taxa natural de desemprego, ou seja, a criação de um exército de reserva de trabalhadores para quebrar os sindicatos. Ademais, reformas fiscais eram imprescindíveis, para incentivar os agentes econômicos. Em outras palavras, isso significa redução de impostos sobre os rendimentos mais altos e sobre as rendas. (Anderson,1995:11) 
Finalmente esse ideário neoliberal chega a América Latina bem mais sedimentado e experimentado, através de reajustes macroeconômicos derivados do Consenso de Washington. Essa política consistia na substituição do modelo econômico de substituição de importações (que promoveu o desenvolvimento da industria nacional) pela concessão de subsídios e da criação de barreiras tarifárias. Soares (1996), Leher (1998) e Harvey (2005)

$\mathrm{Na}$ década de 1990 essa política chega efetivamente ao Brasil,com o governo de Fernando Collor de Melo, eleito com o objetivo de implantar o neoliberalismo, juntamente com a cartilha do Consenso de Washington. Nesse momento, começa a instalação de uma política de privatização de estatais e estabelecimento de um Estado mínimo com diversas reformas administrativas, que sempre desfavorecia o trabalhador e a população em geral.

Segundo Harvey (2005), a neoliberalização aparece como um projeto utópico de realização de um plano teórico de reorganização do capitalismo internacional; e como um projeto político de restabelecimento das condições da acumulação do capital e de restauração do poder das [elites] econômicas.

Para Gentili (1995), um projeto alternativo que possa servir de contraposição à ofensiva neoliberal não terá nenhum sucesso se não compreender primeiro como funciona essa nova economia do afeto e do sentimento, na qual a apropriada utilização da mídia adquire um papel central. E Collor representou a manifestação mais refinada dessa habilidade, mas, contrariamente à interpretação corrente, essa nova definição de pedagogia dos sentimentos populares não se extinguiu com ele.

Para Harvey (2005), nenhum modo de pensamento se torna dominante sem propor um aparato conceitual que mobilize nossas sensações e nossos instintos, nossos valores e nossos desejos. Se bem sucedido, esse aparato conceitual se incorpora a tal ponto ao senso comum que passa a ser tido por certo e livre de questionamento. Uma espécie de consenso.

Nos dizeres de Leher (1998), após a era de ouro do Keynesianismo, um novo consenso estaria configurando a era do mercado globalizado. Nos termos dos formuladores do Consenso de Washington, após o fracasso das políticas keynesianas - 
que, após a Grande Guerra, caracterizaram o estado providência do Norte e a estratégia de desenvolvimento do Sul - os países em desenvolvimento estariam de acordo que a única via segura para o crescimento e o desenvolvimento seria redimensionar todas as atividades econômico-sociais para o mercado. E um dos principais artífices desta formulação é o Banco Mundial.

Segundo Leher (1998), os acordos de Bretton Woods (1944) originaram o Banco Mundial e o FMI (Fundo Monetário Internacional), ambos em 1945. Estes acordos marcam a supremacia político-econômica dos EUA, em detrimento da hegemonia e do padrão "Libra-Ouro" inglesa.

Leher afirma ainda:

\begin{abstract}
Em um sentido lato, o Banco Mundial tem a atribuição de um grande intelectual orgânico dos interesses representados pelo G-7, atuando como um 'organizador' das políticas dos países em desenvolvimento. Hoje não resta dúvida de que o debate a propósito da governabilidade e das reformas estruturais está sob a direção ideológica dessa instituição. Por meio de seus projetos e programas, ela exerce mais influência sobre a educação do que a UNESCO, sobre a saúde do que a OMS, sobre as condições dos trabalhadores do que a OIT, sobre a agricultura do que a FAO, etc. de fato, o Banco representa uma estrutura material da ideologia da globalização com a função mediadora de organizar e difundir a 'concepção de mundo' que os 'Senhores do Mundo' querem consolidar e reproduzir, neste contexto de crise estrutural." (LEHER, 1998:9-10)
\end{abstract}

Ao final da segunda grande guerra, os EUA saíram fortalecidos econômica e militarmente, mas que, para manter sua supremacia, seria necessário fortalecer os seus principais parceiros. Daí a proposta de um banco voltado para a reconstrução da Europa e do Japão. Nessa perspectiva, o Banco e o Fundo seriam interdependentes: portanto a reconstrução financeira e a reconstrução do comércio seriam processos complementares.

Harvey (2005) afirma que uma variedade de Estados socialdemocratas, democrata-cristãos e dirigistas emergiu na Europa pós Segunda Grande Guerra. Esse processo no Brasil demorou um pouco mais, ocorrendo na chamada Abertura Democrática Brasileira um direcionamento para o pluripartidarismo no país. E 
finalmente na década de 1990, os sociais democratas chegam ao poder. Mas segundo Fernando Henrique Cardoso, eles chegaram a se denominar sócio-liberais, aplicando o socioliberalismo.

Com o Consenso de Washington, que consistiu num amplo conjunto de reformas estruturais, temos as premissas das transformações que ocorreram principalmente na América Latina, dividida em dois momentos: o primeiro no final dos anos 1980 e o segundo já em meados dos anos 1990. O que nos interessará será esse segundo momento, que focaliza as reformas no sistema educacional.

A estratégia dessa reforma educacional será exposta nas páginas subseqüentes desse estudo.

\subsection{Neoliberalismo e as políticas do Banco Mundial para a educação}

O interesse do Banco Mundial pela educação data do final da década de 1970, quando esta área foi destacada como uma das políticas setoriais da instituição.

Deste modo, como afirma Leher (1998), a educação, conferida como assunto dos "homens de negócios", teve o Banco Mundial como um dos principais artífices. A UNESCO foi esvaziada - e a saída dos EUA deste organismo assume o valor de ícone - e suas prerrogativas foram deslocadas para o Banco. Ungido pelo departamento de Estado dos EUA, o Banco pode encaminhar a maior reforma educacional da história, abrangendo simultaneamente a América Latina, a África e parte da Ásia. Com isso, é instaurado um apartheid educacional planetário, correspondente à "exclusão forçada" que cinde a economia mundial.

Do ponto de vista da perspectiva neoliberal, os sistemas educacionais públicos, apresentam uma crise que reflete uma completa ausência de eficiência, eficácia e produtividade.

Ferreira (2009) afirma que o desenvolvimento dos sistemas educacionais públicos, principalmente nos países em desenvolvimento, carecem de eficiência nos 
serviços prestados. A crise é reflexo da ausência de "qualidade" fruto da improdutividade que caracteriza as práticas pedagógicas e a gestão administrativa na maioria das escolas públicas.

Outra questão seria a importância relativa da Educação nas formulações ideológicas dominantes na América Latina - em particular na do Banco Mundial.

Leher (1998) afirma que tal importância foi crescente no período que compreende as décadas de 1960 a 1990, onde todos os documentos recentes atribuem à Educação importância decisiva tanto para o crescimento econômico, quanto, e sobretudo, para o aliviamento da pobreza dos países em desenvolvimento.

$E$ isso é comprovado pelos documentos aprovados pela Conferência Mundial sobre Educação para Todos, que ocorreu entre os dias 5 a 9 de março de 1990, em Jomtien, na Tailândia. Patrocinada pelo Banco Mundial, tal conferência legitima as necessidades de mudanças na educação, no começo de uma década de amadurecimento neoliberal e de transformações no mundo capitalista. Neste momento, o planejamento das políticas educacionais nos países pobres são postas a prova, abrindo um caminho para a legitimação de intervenções estrangeiras, mediadas pelo capital, em tais países.

Com um discurso falso sobre qualidade e combate a pobreza, acesso universal a educação básica, assim como utilização de termos do mundo empresarial como metas, flexibilidade e resultados, tal conferência vem para institucionalizar e legitimar a influência de organismos multilaterais como o próprio Banco Mundial na soberania dos países pobres.

Portanto há um discurso de satisfação de necessidades de aprendizagem, com uma abertura, falsamente qualificada como democrática, para a construção e difusão de parâmetros mundiais, ditos educacionais, mas que visam fundamentalmente formar trabalhadores polifuncionais, adaptáveis às diversas mudanças do mercado, ideologicamente subordinado a perspectiva da resolução individual de seus problemas e adaptados a esfera da reprodução ampliada do capital.

Com isso, Gentili (1996) afirma que para os neoliberais os sistemas educacionais não enfrentam uma crise de democratização, mas uma crise de gerência 
que provoca certos mecanismos de "iniquidade" escolar, como evasão, repetência, analfabetismo funcional, etc. Segundo ele, essa crise se explica pelo caráter estruturalmente ineficiente do estado para gerenciar políticas públicas e, que somente uma reforma no sistema escolar promova mecanismos que regulem a eficiência, a produtividade e a eficácia, trazendo a "qualidade" aos sistemas educacionais. E isso é o mote principal da Conferência de Jomtien.

Essas três justificativas apresentadas dão uma certa legitimidade, na visão dos teóricos neoliberais, para tais ações reformistas em toda a América Latina. Nesse sentido a educação deixa de ser um direito de cidadania para se tornar uma mercadoria, onde os educandos passam a ser consumidores.

Com isso, a estratégia neoliberal consiste em transferir a educação da esfera da política para a esfera do mercado, transformando-a em condição de propriedade, questionando o seu caráter de direito.

Existe ainda um discurso de qualidade nestas políticas neoliberais para a educação. Para Gentili (1996), a ausência de um verdadeiro mercado educacional em contraposição a escola estatizada permite entender a "crise" de qualidade que assola os sistemas educacionais.

Enguita (1994) afirma que a cada período da história da escolarização há sempre uma busca por uma melhor "qualidade" educacional. Nos EUA, no início do século XX, a qualidade foi vista dentro de princípios da "igualdade", pois a padronização da produção e a chegada de inúmeros imigrantes possibilitou construírem escolas, que tinham como objetivo massificar a força de trabalho e a cultura.

Já a idéia de qualidade nos sistemas educacionais do estado do Bem Estar estava associada a ideia de que mais recursos materiais e humanos por usuário era igual a maior qualidade, como afirma Ferreira (2009). Ele vai além afirmando ainda que, a partir dos anos de 1980, nos países centrais, o conceito de qualidade se deslocou dos recursos para eficácia do processo, onde a lógica já não era mais dos serviços públicos, mas de produção empresarial.

Há, portanto, o aparecimento de uma espécie de ideário onde qualquer proposição relativa a conservar, melhorar ou mudar isto e aquilo, não importando o que 
seja, deve explicar-se em termos de qualidade, como indaga Gentili (1994) E na educação não foi diferente.

No que se refere à relação entre a qualidade da educação e a problemática do acesso, Vieira (2008) afirma que considerando as peculiariedades históricas e culturais de cada país que buscou o caminho da democracia burguesa e da democratização da educação pública, o deslocamento da pauta de acesso à educação - por mais vagas e mais espaços e materiais - para o da qualidade ocorre quando a pauta do acesso fica esvaziada pelo cumprimento da promessa da construção da vaga para todos.

Vai além dizendo que em tese, depois de se conquistar o acesso, passa-se a brigar pela qualidade (claro que isso não é uma norma, mas uma recorrência histórica).

Para Gentili (1994), no mundo do ensino, no que tange a igualdade, a busca da qualidade se refere à passagem das melhorias quantitativas às qualitativas. Não apenas mais, mas melhores professores, materiais e equipamentos escolares, ou horas de aula, por exemplo. Mas a palavra de ordem da qualidade encerra também um segundo significado: não o melhor (em vez do mesmo ou de menos) para todos mas para uns poucos e igual ou pior para os demais.

Complementando essa idéia de qualidade, Enguita (1994) afirma que a reivindicação da qualidade na educação torna-se justa e legítima, sendo preciso reconhecê-la, mas não sem antes desvelar os sentidos políticos de quem está reivindicando, pois - tendo em vista os interesses políticos e econômicos, bem como os principais campos de disputa onde os conflitos se expressam e acontecem - há uma tendência eminente do discurso da qualidade colocar em segundo plano o da igualdade.

Com isso, a igualdade de oportunidades pode ficar de fora do discurso sobre a qualidade.

Portanto, Ferreira (2009) afirma que essa visão de qualidade no ensino, pelo entendimento neoliberal, deixa transparecer que a "qualidade" é uma questão meramente técnica, baseada em "produto" do resultado educacional. Afirma também que a qualidade é passível de "mediação" de "padrões" que se tornam indicadores, de repetência, de evasão, de aproveitamento na aprendizagem e outros tantos mais. 
A neoliberalização da educação no Brasil e no estado de São Paulo veremos no capítulo seguinte.

\subsection{Neoliberalismo e a educação no Brasil e no estado de São Paulo}

Até a década de 1960, a educação era uma questão decididamente secundária para o Banco Mundial. Segundo Leher (1998), o antigo vice-presidente do Banco, Robert Gardner disse que não poderia emprestar para a educação e saúde, pois eram um banco. Essa situação começou a mudar durante a gestão Macnamara (a partir de 1968) , quando a ênfase no problema da pobreza fez a educação sobressair entre as prioridades do Banco.

Na década de 1970, o Banco começa a enfatizar a lógica interna dos projetos, como custos e realização física, em detrimento das considerações educativas. Para se ter uma ideia, a educação, no período compreendido entre 1947-1983, foi o menor dos investimentos das prioridades elencadas para o Brasil, como mostra o quadro abaixo:

\section{Quadro 1}

\section{Distribuição setorial dos empréstimos do Banco Mundial ao Brasil}

\begin{tabular}{|l|c|c|c|}
\hline \multicolumn{1}{|r|}{ Períodos } & $\mathbf{1 9 4 7 -}$ & $\mathbf{1 9 6 6 -}$ & $\mathbf{1 9 7 6 - 1 9 8 3}$ \\
Setor & $\mathbf{1 9 6 5}$ & $\mathbf{1 9 7 5}$ & \\
\hline agricultura & - & $9,2 \%$ & $22,1 \%$ \\
\hline energia & $92,5 \%$ & $32,6 \%$ & $18,7 \%$ \\
\hline transportes & $7,5 \%$ & $33,0 \%$ & $12,6 \%$ \\
\hline indústria & - & $19,7 \%$ & $13,0 \%$ \\
\hline desenvol. urbano & - & - & $9,0 \%$ \\
\hline água e esgoto & - & $3,0 \%$ & $13,1 \%$ \\
\hline educação & - & $1,6 \%$ & $1,6 \%$ \\
\hline outros & - & $0,8 \%$ & $9,8 \%$ \\
\hline
\end{tabular}


Fonte: Araújo (1991) apud Soares (1996)

$\mathrm{Na}$ virada neoliberal da década de 1980, a orientação educacional do Banco sofre uma inflexão em direção ao ensino elementar. A orientação anterior é então duramente atacada como voluntarista e dispendiosa conforme Leher (1998).

$\mathrm{Na}$ década de 1990, a inflexão da década anterior permanece válida, porém a reforma, além de estrutural como nos anos 1980, assume uma feição mais marcadamente ideológica, centrada nas conexões pobreza-segurança-domínio/direção.

No caso brasileiro, as condições estruturais da política educacional objetivam situá-la como uma política que nada tem de autóctone, pois, a despeito da situação concreta de cada país de América Latina, o Plano está inscrito e determinado no contexto de reformas econômicas, como por exemplo o Consenso de Washington, monitoradas pelo FMI e o Banco Mundial.

Segundo Ferreira (2009), as estratégias destas instituições para o sistema educacional brasileiro são pensadas dentro de tais preceitos neoliberais. O seu diagnóstico ressalta a baixa qualidade do sistema que reflete nos altos índices de repetência e evasão escolar, gerando para os governos elevados custos e desperdício de força de trabalho.

De acordo com Soares (1996), no Brasil, a partir do final da década de 1980, os empréstimos do Banco Mundial para o setor educacional têm aumentado consideravelmente. Enquanto nos anos 1987-1990 constituíram somente 2\% dos empréstimos, nos anos 1991-1994 chegaram a representar 29\% do total, como mostra o quadro abaixo:

\section{Quadro 2}

\section{Participação setorial dos empréstimos aprovados pelo Banco Mundial para o Brasil - 1987-1994}




\begin{tabular}{|l|c|r|c|c|}
\hline & $\begin{array}{c}\mathbf{1 9 8 7 - 1 9 9 0} \\
\text { (U\$ milhões) }\end{array}$ & $\mathbf{\%}$ & $\begin{array}{c}\mathbf{1 9 9 1 - 1 9 9 4} \\
\text { (U\$ milhões) }\end{array}$ & \% \\
& & & & \\
\hline agricultura & 2.279 & 47 & 372 & 10 \\
\hline energia & 479 & 10 & 260 & 7 \\
\hline transportes & 604 & 12 & 308 & 8 \\
\hline finanças & 0 & 0 & 350 & 9 \\
\hline desenvol. urbano & 575 & 12 & 404 & 11 \\
\hline água e esgoto & 410 & 8 & 794 & 21 \\
\hline pop., saúde e nut. & 475 & 10 & 160 & 4 \\
\hline educação & 74 & 2 & 1.059 & 29 \\
\hline Total Brasil & 4.896 & 10 & 3.707 & 100 \\
& & 0 & & \\
\hline
\end{tabular}

Fonte: Relatórios do Banco Mundial (vários anos) apud Soares (1996)

Especialmente no Brasil, as prioridades elencadas no quadro 1 são substituídas por um financiamento crescente na educação, principalmente nesse intervalo de seis anos. O total de financiamento do Banco Mundial ao Brasil diminui nesse período, mas o da educação aumenta consideravelmente.

Como justificativa disso, Tommasi (1998) aponta que, para o Banco Mundial, os fatores que mais contribuem para a baixa qualidade e ineficiência da educação pública no Brasil são: 1) A falta de livros didáticos e outros materiais pedagógicos; 2) A prática pedagógica inapropriada, que estimula os professores a reprovar; 3) A baixa qualidade da gestão dos sistemas educacionais.

Como resposta a isso, e com foco na contribuição para que os estudantes alcancem uma melhor aprendizagem e com redução de repetência, o Banco Mundial estabelece como prioritárias, no Brasil, as seguintes medidas: 1) Providenciar livros didáticos e outros materiais de ensino; 2) Melhorar as habilidades dos professores, buscando uma capacitação em serviço; 3) Elevar a capacidade de gerenciamento, buscando uma integração entre as diversas esferas de poder (federal, estadual e municipal). 
Para efeito do estudo, e percorrendo os objetivos centrais desse trabalho, vamos nos ater ao ensino básico como aponta Tommasi (1998:197) apud BANCO MUNDIAL ${ }^{4}$ : "Como em outras partes do mundo, a pesquisa no Brasil mostra que o retorno social do investimento em educação primária $(36 \%)$ é consideravelmente maior que o investimento quer na educação secundária (5\%) quer na superior $(21 \%)$ ".

O ensino básico, ao invés de ser concebido como uma modalidade que abrange o ensino fundamental e médio, é reduzido ao nível "fundamental", sobretudo ao primeiro segmento. Leher (1998) afirma que esta redução torna-se evidente na "Conferência Mundial de Educação para Todos", realizada em Jomtiem, 1990, sob a liderança do Banco Mundial, na qual a escola elementar é tida como uma instituição centrada mais nos valores e nas atitudes (flexibilidade, atitude favorável ao mercado, etc.) do que nos fundamentos do conhecimento científico, artístico e cultural (daí o esvaziamento da formação do professor).

O nível elementar é tido como o mais importante pois, diferente do ensino superior e tecnológico, apresenta, na avaliação dos organismos internacionais, a mais alta taxa de retorno do capital no tempo, como exposto anteriormente. E no caso brasileiro, tal nível de ensino está sob a responsabilidade dos estados da federação.

No estado de São Paulo, as intervenções do Banco Mundial e sua política neoliberal são plenas. O início das negociações começou já em 1987, com preparação do projeto entre 1988-1989. Com a aprovação do projeto em 1991, o depósito do empréstimo foi feito depois, já no ano de 1992. A duração do projeto foi de 5 anos, com uma abrangência para a pré-escola e o ciclo básico como afirma Tommasi (1998)

Para se ter uma ideia, nesse período, foram investidos 600 milhões de dólares, divididos nas seguintes ações: melhoria da rede física, capacitação, livros didáticos e pedagógicos, merenda escolar, educação pré-escolar, desenvolvimento institucional, saúde escolar, avaliação e disseminação do projeto e gerenciamento do projeto, como afirma Tommasi (1998)

Nesse tempo, ocorreram várias mudanças de governo, cada um dos quais reformulando o projeto segundo suas prioridades. Os novos governantes, às vezes, não

\footnotetext{
${ }^{4}$ Banco Mundial (1995 a:11)
} 
se sentem comprometidos com empréstimos contraídos pelo governo anterior, o que provoca atrasos nos gastos e pagamentos de juros. E mesmo tendo vários governos que pertencem a um mesmo partido, disseminando esse ideário neoliberal em São Paulo, acontecem tais fatos.

Segundo Tommasi (1998), o projeto de São Paulo, na sua formulação original, segue "ao pé da letra" as orientações estabelecidas pelo Banco na época, incluindo os componentes de merenda, educação pré-escolar e saúde escolar. Sendo considerado modelo para o Banco Mundial, o projeto para São Paulo prevê a realização de uma série de estudos e a divulgação dos resultados através de conferências anuais. Como afirma Tommasi (1998:204) apud BANCO MUNDIAL ${ }^{5}$ :

O projeto São Paulo, assim como foi o projeto EDURURAL ${ }^{6}$,
inclui um componente importante de pesquisa e avaliação
que contribuirá para a compreensão de que tipos de
investimentos educacionais representam uma maior relação
custo-benefício para a melhoria do rendimento escolar de
crianças de baixa renda

Portanto, tais políticas neoliberais foram iniciadas no primeiro governo de Mário Covas (1994/1998), sob a direção da então secretária da Educação, Rose Neubauer. Neste momento, o presidente da república era da mesma tendência e mesmo partido de Covas, Fernando Henrique Cardoso. Nesta década de 1990, as reformas educacionais não autóctones estavam em implantação nesse estado, visto que, nessa mesma época, era discutida e implementada, a partir de 1996, a nova Lei de Diretrizes e Bases da Educação (LDB), assim como os Parâmetros Curriculares Nacionais (PCNs). O mesmo projeto estava em São Paulo e no Brasil, sendo que boa parte das políticas que foram assumidas neste período não eram de governos, mas políticas de Estado; logo, muito mais perenes, longevas e comprometedoras de uma sociedade inteira, por gerações.

Essa política teve continuidade com o governador Geraldo Alckmin, tendo à frente da Secretaria da Educação Gabriel Chalita. A partir de 2006, é eleito José Serra

\footnotetext{
${ }^{5}$ Banco Mundial (1995 a:59)

${ }^{6}$ Ver Tommasi (1998)
} 
para governador, sendo ali colocada essa nova proposta de currículo para a educação paulista.

No ano de 2007 a resolução de $n^{\circ} 92$ de 19/12/07 estabelece as diretrizes curriculares do ensino fundamental e médio da rede paulista, indicando um caminho tortuoso, antidemocrático e sem consulta ao Conselho Estadual de Educação (CEE) e as diversas comunidades escolares. Esse órgão (CEE), que segundo a LDB vigente, deveria ser deliberativo e majoritário nas decisões educacionais do estado, assim como a classe do magistério e sua comunidade escolar.

Ao longo dos anos seguintes, várias resoluções foram baixadas, mostrando uma política de "remendos" que não condizem com as reais necessidades dentro das práticas escolares, as mais interessadas nessas mudanças. O secretário da educação é um dos responsáveis pela política educacional do governo PSDB/DEM (Partido da Social Democracia Brasileira/Democratas) no governo FHC, mostrando claramente a opção de politização, às vésperas da eleição para presidência da república até então, das pastas governamentais do governador José Serra.

Segundo Lopes (2008), no caso brasileiro, as relações com agência de fomento, como o BID e o Banco Mundial, desenvolveram-se de forma bastante estreita na vigência dos dois mandatos presidenciais de Fernando Henrique Cardoso - em virtude, também, de lideranças dessas reformas no MEC (Ministério da Educação) terem atuado diretamente em tais agências.

Paulo Renato Souza, ex-ministro da educação, e Guiomar Namo de Mello ${ }^{7}$, membro do Conselho Nacional de Educação (MEC) e relatora do parecer sobre as Diretrizes Curriculares da Educação, foram consultores do Banco Mundial. Cláudio de Moura Castro, assessor do MEC nas reformas do Ensino Médio e da Educação Profissional, é sênior education advisor na unidade de educação do Departamento de Desenvolvimento Sustentável do BID e possui várias publicações nesta agência sobre as políticas do Ensino Médio.

Tanto na proposta geral dos currículos, como na proposta para o ensino de geografia, temos quase uma reprodução das recomendações (obrigações) dos PCNs e

\footnotetext{
${ }^{7}$ E não por coincidência, Guiomar Namo de Mello é uma das idealizadoras da nova proposta curricular do estado de
} São Paulo, juntamente com até então Secretário da Educação do estado Paulo Renato de Souza. 
da LDB (Lei 9394/1996), baseadas nas premissas neoliberais do Banco Mundial, além das metodologias e objetivos das avaliações de desempenho como o SAEB e o ENEM, através do chamado SARESP

Com o modelo da lei no 9.395/96 (LDB), nesta fase tivemos: a municipalização do ensino (que continua até hoje, concentrada no interior, mas não com tanto rigor como antes, pelo menos na cidade de São Paulo), a criação dos ciclos (apenas como forma de agilizar o processo educacional), a política de bônus e da meritocracia para o funcionalismo público (que não representa uma política salarial consistente e com critérios muitas vezes escusos), além da progressão continuada que, mal implementada, gerou, depois de 10 anos, a péssima qualidade da educação, com alunos do ensino médio tendo dificuldades em simplesmente ler e escrever.

Com essas medidas sendo implementadas há pelo menos duas décadas, dando estrutura para a concepção de uma política educacional muito mal executada, a nova proposta curricular da rede estadual de ensino, assim como sua política pública central (O Plano de Dez metas para a Educação Paulista), num engajamento com uma escola pública que não seja regulada pela lógica do mercado, mas que tenha sua qualidade fincada no princípio de que só o trabalho cria riqueza, precisa ser estudada, discutida, criticada.

Uma escola pública, acessível a todos os trabalhadores, lócus em que se gestam transformações integrais dessa sociedade, embora em seu interior. justificando a construção desse trabalho.

\subsection{Contextualização do Plano de Dez metas para a Educação do governo do estado de São Paulo}


Pouco é falado, publicado ou discutido sobre a política pública para a educação do estado de São Paulo denominado Plano de Dez Metas para a Educação. Mas, para iniciar tal discussão, vamos nos ater aos significados e sentidos de alguns termos.

Primeiramente, se tratando de uma política pública para a educação, o termo "meta" se aproxima bastante de um pensamento voltado para a gestão empresarial. Segundo PLACONÁ (2008), a principal razão de se escrever as metas do negócio é procurar adequar e orientar o caminho a ser seguido para que a empresa esteja cumprindo sua missão em direção à sua visão. Ressalta também que a "meta" é uma segmentação do objetivo, em que o aspecto quantitativo tem uma importância maior, ou seja, é mais preciso em valor e data, pois é mais próximo que o objetivo.

O importante a salientar é que essa política, assim que anunciada em 20/08/2007, abre o espaço para a consolidação do novo currículo do estado de São Paulo. Assim sendo, o currículo é pensado dentro de uma relação estabelecida nessa política de metas. O cumprimento dessa é previsto para 2010, ainda no governo de José Serra.

Tais metas foram expostas da seguinte forma ${ }^{8}$ :

1 - Todos os alunos de 8 anos plenamente alfabetizados;

2 - Redução de $50 \%$ das taxas de reprovação da $8^{\mathrm{a}}$ série;

3 - Redução de $50 \%$ das taxas de reprovação do Ensino Médio;

4 - Implantação de programas de recuperação de aprendizagem nas séries finais de todos ciclos $\left(2^{\mathrm{a}}, 4^{\mathrm{a}}\right.$ e $8^{\mathrm{a}}$ séries do Ensino Fundamental e $3^{\mathrm{a}}$ série do Ensino Médio);

5 - Aumento de $10 \%$ nos índices de desempenho dos ensinos fundamental e médio nas avaliações nacionais e estaduais;

6 - Atendimento de $100 \%$ da demanda de jovens e adultos de Ensino Médio com oferta diversificada de currículo profissionalizante;

7 - Implantação do Ensino Fundamental de 9 anos, em colaboração com os municípios, com prioridade à municipalização das séries iniciais $\left(1^{\mathrm{a}}\right.$ a $4^{\mathrm{a}}$ séries);

\footnotetext{
${ }^{8}$ http://www.saopaulo.sp.gov.br/spnoticias/lenoticia.php?id=87027: acessado em 20/04/2011.
} 
8 - Utilização da estrutura de tecnologia da informação e Rede do Saber para programas de formação continuada de professores integrados em todas as 5.300 escolas com foco nos resultados das avaliações; estrutura de apoio à formação e ao trabalho de coordenadores pedagógicos e supervisores para reforçar o monitoramento das escolas e apoiar o trabalho do professor em sala de aula, em todas as Des (Diretorias de Ensino); programa de capacitação dos dirigentes de ensino e diretores de escolas com foco na eficiência da gestão administrativa e pedagógica do sistema;

9 - Descentralização e/ou municipalização do programa de alimentação escolar nos 30 municípios ainda centralizados;

10 - Programa de obras e infraestrutura física das escolas:

Garantia de condições de acessibilidade em $50 \%$ das escolas, para atender a demanda dos alunos com deficiência; construção de 74 novas unidades, reforma e ampliação de 77escolas (417 salas de aula); extinção das salas com padrão Nakamura; recuperação e cobertura de quadras de esportes; implantação de circuito interno de TV para melhorar a segurança em escolas da Grande São Paulo; 100 \% das escolas com laboratórios de informática e de ciência; 100 \% das salas dos professores com computadores, impressoras e ambiente de multimídia; atualização e informatização do acervo de todas as bibliotecas das 5.300 escolas.

Exposto essas metas, percebe-se que as ações propostas realmente se ajustam as condições neoliberais e dos ajustes coordenados pelo Banco Mundial. Há uma intenção qualitativa nas ações, mas traduzidas em números, caracterizando-a como um sistema verdadeiramente empresarial para a educação.

Todas as intenções são quantificadas, dando especial atenção ao ensino básico (Ensinos Fundamental I e II), focado essencialmente no aumento dos índices de aprovação e ações que privilegiem métodos que facilitem a não reprovação dos estudantes, como implantação dos programas de recuperação de aprendizagens, retorno dos adultos às escolas e ensino profissionalizante. 
Porém há de se considerar que tais ações são efetuadas e significadas pelas avaliações externas dos governos federal e estadual, legitimando ainda mais as orientações dos organismos estrangeiros.

Outra premissa do Banco Mundial está alocada na reestruturação física das escolas, onde tais políticas foram pensadas no Projeto São Paulo elencadas anteriormente por Tommasi (1998). A municipalização das escolas também é encarada como uma meta, levando a uma descentralização e divisão de atribuições entre estado e município. Por fim é estabelecida uma política de formação para os professores e administradores escolares.

Com esse Plano de Dez Metas para a Educação no estado de São Paulo, é estabelecido um "norte" para a implementação da proposta curricular na rede onde, tais propostas de ações estarão ligadas diretamente com as políticas neoliberais, levadas a cabo pelo Banco Mundial, quantificando, superficializando e simplificando o destino de milhões de estudantes da rede pública paulista.

\subsection{O Plano de Dez Metas para a Educação do estado de São Paulo e a proposta curricular}

Além dos princípios e fundamentos do novo currículo da rede pública estadual de São Paulo, baseado na pedagogia das Competências e Habilidades, referenciadas pelas avaliações externas e utilização de material próprio para a utilização de administradores escolares, professores e alunos, há um sentido mais político da concepção curricular.

Com o plano de dez metas anunciado, o currículo toma para si essas ideias e ações, especificando suas concepções estruturalizantes e pedagógicas. Para uma melhor instrumentalização curricular, tais metas são tornadas mais específicas, tornando sua implementação teoricamente viável. 
Várias reorientações curriculares foram formuladas no estado de São Paulo e em outros estados da Federação. Segundo Souza (2006), no início da década de 1980, embora ainda estivessem em vigor as diretrizes gerais para o currículo estabelecidas pela Lei n. 5.692/71, começaram a surgir iniciativas governamentais de revisão e reformas curriculares em vários estados brasileiros.

Souza (2006) vai além afirmando que esse movimento de reformulação curricular é representativo do jogo de determinações e iniciativas que envolvem os agentes educativos na concretização do currículo. Nesse caso, as iniciativas estaduais foram antecipatórias em relação à ação do poder público federal e reafirmaram a potencialidade criativa dos sistemas estaduais de ensino.

Não obstante, na década de 1990, observamos o movimento contrário. Nos últimos anos acentuou-se, visivelmente, a atuação do governo federal no âmbito das prescrições curriculares em todos os níveis de ensino que passou a assumir, inclusive, competências que vinham sendo historicamente exercidas no âmbito dos governos estaduais, tais como a produção de materiais de orientação curricular para o ensino fundamental e médio.

Dado que a política curricular constitui um aspecto específico da política educacional, sua investigação significa, de certa maneira, uma avaliação dos condicionantes da possibilidade que tem o Estado de provocar/influenciar mudanças na prática educativa e, como decorrência, promover a qualidade da escola pública.

De fato, aquilo que se define como legítimo para ser transmitido, ensinado e aprendido nas escolas, não é questão menor, mas se coloca no centro mesmo da definição de uma política cultural de repercussões a longo prazo. Por isso, a atuação do Estado em relação ao currículo não se limita a prescrever a seleção cultural mediante dispositivos legais.

A política curricular envolve também a elaboração de meios - material de orientação e controle -, que visam apresentar aos sistemas de ensino e aos professores o currículo prescrito, indicando com um pouco mais de especificações, as finalidades, os conteúdos e o modo de ensinar (metodologia e avaliação). 
Esses materiais direcionam a produção de livros didáticos que servem efetivamente como orientadores do desenvolvimento do currículo; eles também exercem um papel relevante na formação inicial e continuada de professores, constituindo referência para a avaliação e controle do conhecimento nos sistemas educativos que intervêem na prática educativa, como afirma Gimeno (1998). E isso é posicionado perante a política pública para a educação de metas do estado de São Paulo.

A partir dessas metas, formuladas entre 2007-2008, o governo do estado de São Paulo realmente lança um desafio bastante ambicioso para a melhoria da qualidade da educação.

De difícil estudo e comprovação dessa metas, devido à complexidade da rede como um todo, além de seu enorme tamanho e a atualidade de suas propostas, com uma escassez bibliográfica sobre o tema, a ideia é que com a análise dos documentos e artigos disponíveis contextualizem as influências neoliberais e a ressignificação da escola como empresa.

Com uma crítica a estratégia da melhora estrutural, material e física, em detrimento aos fatores humanos, numa implementação antidemocrática, pode-se apontar um contrassenso nas expectativas elencadas pela própria SEE, que, teoricamente soam como uma corporação capitalista, traduzida nas expectativas gerais da SEE, que abaixo elencam-se:

monitoramento permanente das ações; integração da equipe e articulação interna; foco nos resultados e eficiência do processo de gestão; antecipação de problemas e racionalização das soluções; comunicação interna e externa. ${ }^{9}$

Através dessas expectativas, a SEE espera que o desenvolvimento curricular se torne participativo, com uma gestão informacional eficiente, e uma conseqüente integração das equipes.

\footnotetext{
${ }^{9}$ http://www.saopaulo.sp.gov.br/spnoticias/lenoticia.php?id=87027: acessado em 20/04/2011.
} 
Como meio de se avaliar isso, o processo seria a implementação mais integrada do SARESP ao currículo, avaliando diretamente os alunos, de uma forma quantitativa, por amostragem e de uma forma bastante superficial. Queremos com essa pesquisa indicar que existe uma limitação avaliativa do processo curricular apenas com esse instrumento, não mostrando as reais facetas da organização dessa nova proposta curricular nas escolas.

O Plano de Dez Metas para a Educação do estado de São Paulo, assim como seu currículo, são facetas da mesma moeda neoliberal. A educação tomada como empresa desconsidera princípios básicos dos valores humanos e transmissão dos valores culturais presentes em nossa sociedade.

Vieira (2008) afirma que temos que ter prioridade à defesa incondicional da educação pública, gratuita, laica, para todos e com qualidade social. Educação esta concebida como um poderoso instrumento, essencial e privilegiado, para que todos os cidadãos do país tenham acesso aos saberes e valores essenciais para a tomada de consciência de seus papéis históricos na e com a humanidade e, sobretudo, para a construção de uma atitude sólida e responsável diante dos desafios de nossos tempos.

No capítulo seguinte, essa indagação é fonte de análise no universo das teorias curriculares que, de certa forma, orientam e organizam as concepções educacionais e seus objetivos perante nossa sociedade. O que dizem as teorias curriculares sobre essa mercantilização da educação brasileira e paulista? Será mesmo esse caminho a trilhar?

\section{CAPÍTULO 2}

\section{As Teorias de Currículo e os Currículos de Geografia}


As ideias e concepções curriculares são essenciais para o estudo e análise dos significados e a representação da estrutura de funcionamento de uma rede de ensino. Com isso, alguns autores são fundamentais na construção dessa concepção, tais como Antônio Flávio Moreira, Gimeno Sacristán, Michael Apple e Tomaz Tadeu da Silva entre outros. Com a contribuição de tais autores, há possibilidade de traçar um paralelo com as transformações que a geografia enquanto disciplina escolar e acadêmica sofre.

Toda essa abordagem acerca do campo do currículo torna-se necessário para contextualizar o documento de Implementação Curricular à luz das teorias do currículo.

\subsection{Uma introdução ao estudo dos currículos}

Adequada a seu público e a seus meios, uma concepção geral de currículo deve apresentar o interesse pelo local e global, com uma dinâmica de acordo com as necessidades da escola e os interesses da rede de ensino. O currículo é visto como um processo de racionalização de resultados educacionais, cuidadosa e rigorosamente especificados e medidos, ou seja, uma especificação precisa de objetivos, procedimentos e métodos.

Segundo Sacramento (2007), os currículos têm por objetivo orientar a construção

do conhecimento escolar. É por meio deles que são regidas a teoria e a prática de todo o processo no ambiente e a dinâmica do tipo de ensino que a escola oferece.

Não são simplesmente as grades curriculares, mas são as transformações de todo um contexto: para que e para quem se ensina, do que se ensina e qual a intenção política e social que irá contemplar. A forma como se produz o currículo está relacionado ao tipo de estudante que está se formando, com o objetivo da formação docente e com o ideal da escola. 
Candau \& Moreira (2006), afirmam que a palavra currículo possui várias definições no campo pedagógico, que carregam consigo distintas concepções, derivadas dos diversos modos como à educação é concebida historicamente, bem como das influências teóricas que afetam e se fazem hegemônicas em um dado momento.

Ainda em Sacramento (2007), o currículo surge, efetivamente, a partir do momento em que a escola se organizou para ser uma instituição formal de ensino, no fim do século XVIII, com o objetivo explícito de sistematizar o conhecimento transmitido à população.

Desde então, o estudo do currículo e o interesse pela sua organização são ferramentas importantes para o Estado e para o sistema econômico em formar futuros profissionais para o mercado de trabalho, porque se direcionam os objetivos e os conteúdos necessários para a compreensão da realidade e a orientação de técnicas, normas e formas que permitam o ingresso ao mercado de trabalho, para o vestibular e para a vida social.

Sendo assim, Ferreira (2009) afirma que currículo inicialmente pode ser entendido como um arranjo sistemático de matérias, ou um elenco de disciplinas e de conteúdos. Ele prossegue dizendo que currículo é entendido também como um conjunto de estratégias para preparar o jovem para a vida adulta, ou como um conjunto de experiências trabalhadas pela escola, ou mesmo conjunto de atividades e dos meios para alcançarem os fins da educação.

Nessas perspectivas, o currículo envolve a definição de objetivo e seleção, organização e avaliação dos conteúdos escolares. Silva (2007) diz que de certa forma, todas as teorias pedagógicas e educacionais são também teorias sobre o currículo.

Para Moreira (1995), uma das classificações coerentes para se entender o campo curricular é baseada no americano James Macdonald. Essa classificação é uma aplicação da teoria dos interesses de Habermas, só que alocada ao campo do currículo.

Ela é justificada da seguinte forma: a) o conhecimento curricular é parte do conhecimento humano; e b) o objeto do conhecimento curricular é o conhecimento 
escolar - sua seleção, organização e transmissão. Os três interesses básicos de Habermas - ainda em Moreira (1995) - é o interesse em controle técnico, interesse em compreensão (ou interesse em consenso ou interesse prático), e interesse em emancipação (ou interesse crítico), são considerados por Macdonald como as fontes das diferenças na teoria e na prática escolar.

Já Candau \& Moreira (2006) afirmam que diferentes fatores sócio-econômicos, políticos e culturais contribuem para que o currículo seja entendido de diversas formas. Nessa perspectiva, o currículo escolar é um espaço conflitivo de interesses sociais e culturais diversos.

O currículo é uma maneira de organizar uma série de práticas educativas e como construção cultural, refletindo uma compreensão institucionalizada e de funções sociais da escola num dado tempo histórico.

Porém, se procurarmos compreender o currículo como um espaço conflitivo, de interesses sociais e culturais, perceberemos que os currículos transcendem a todos esses princípios. Quanto a isso, Silva (1999) e Moreira (1995) lançam acertadamente quatro hipóteses para essa premissa:

Primeira hipótese: os currículos escolares transcendem os guias curriculares porque todo documento formulado - o currículo prescrito $^{10}$ - por uma secretaria de educação ou uma instituição escolar que apresenta determinados conteúdos e conhecimentos no seu processo de elaboração, quando posto em prática, nas aulas, sofre uma intervenção de forma direta e indireta por parte dos professores e alunos. Ou seja, no dia-a-dia curricular acontecem muitas manifestações não prescritas no currículo formal que junto com as ações de docentes e discentes formam o currículo vivido ou currículo em ação. ${ }^{11}$

Segunda hipótese: o currículo não é apenas um conjunto de objetivos, conteúdos, experiências de aprendizagem e avaliação. Com isso, esses elementos não são apenas de ordem e natureza técnicas, mas também, de ordem política e cultural, estabelecendo as formas como concebemos a sociedade, a escola e o conhecimento.

\footnotetext{
${ }^{10}$ Ver SACRISTÁN (1998)

${ }^{11}$ Ibidem.
} 
Terceira hipótese: o currículo escolar não lida apenas com o conhecimento escolar, mas com diferentes aspectos da cultura, pois o conhecimento é apenas uma das facetas da cultura construída e reconstruída no ambiente escolar.

Quarta hipótese: a seleção de conteúdos e procedimentos que compõe o currículo é um processo acima de tudo político, pois no ato de selecionar e organizar os conteúdos escolares, os parâmetros científicos utilizados como critério não são neutros ou desinteressados. Há certamente neles relações de poder.

Essas são teorias formuladas a partir de autores que trabalham com currículo, indicando a complexidade da temática curricular, principalmente a que nos remete nas próximas páginas ao currículo da geografia e da Implementação da proposta curricular do estado de São Paulo.

Ferreira (2009) afirma que é possível definir o currículo escolar como processo social constituído de lutas e conflitos, nos quais diferentes concepções, ideologias e tradições entram em cena, considerando e selecionando, em determinado contexto histórico, alguns conhecimentos como socialmente válidos e, conseqüentemente, desconsiderando outros conhecimentos por não entendê-los como válidos.

Os próximos passos desse estudo esperam concordar ou não com tais premissas.

\subsection{Teorias tradicionais e críticas sobre o currículo}

A existência de teorias sobre o currículo está identificada com a emergência do campo do currículo como um campo profissional, especializado, de estudos e pesquisa sobre currículo. Silva (1999)

Especialmente na década de 1960, devido aos movimentos de contestação de caráter social, cultural e político distribuídos pelo mundo, surgem novas teorizações no campo da educação. 
Portanto, essas teorizações procuram questionar o pensamento e as estruturas educacionais tradicionais. Nos EUA essas novas teorizações ocorrem no chamado "Movimento de Reconceptualização" e na Inglaterra a "Nova Sociologia da Educação".

O Movimento de reconceptualização exprimia uma insatisfação de pessoas do campo do currículo com os parâmetros tecnocráticos estabelecidos pelos modelos tradicionais de currículo. Este movimento, na Europa, começava a perceber que a compreensão do currículo como uma atividade meramente técnica e administrativa não se enquadrava nas novas teorias sociais que ganhavam força em vários campos do conhecimento e também da pedagogia.

Já na Inglaterra, a crítica feita aos modelos curriculares tradicionais ocorreu a partir do campo da sociologia. A "antiga" sociologia da educação inglesa avaliava o fracasso das crianças mais pobres com dados puramente estatísticos, com variáveis de saída (sucesso ou fracasso escolar) e de entrada (classe social, renda, situação familiar). Analisava-se o desempenho dos alunos de forma quantitativa e não qualitativa.

Com as teorias de contestação aos currículos tradicionais, temos as críticas teorizadas que questionam o conhecimento corporificado no currículo. Nesse sentido, os conteúdos são associados às relações de poder e a produção de saberes que sustentam a ordenação dos mesmos.

Ferreira (2009) destaca que para essas teorias críticas esse conhecimento não é neutro, puro ou epistemologicamente "correto". Ele não é uma questão meramente técnica, e sim um conjunto de conteúdos e objetivos a serem ensinados.

Como afirma Silva (1999:30):

Ao tomar o status quo como referência desejável, as teorias tradicionais se concentravam, pois, nas formas de organização e elaboração do currículo. Os modelos tradicionais de currículo restringiam-se à atividade técnica de como fazer o currículo. As teorias críticas sobre o currículo, em contraste, começam por colocar em questão precisamente os pressupostos dos presentes arranjos sociais e educacionais. As teorias críticas desconfiam do status quo, responsabilizando-o pelas desigualdades e injustiças sociais.. As teorias tradicionais eram teorias de aceitação, ajuste e adaptação. As teorias críticas são teorias de desconfiança, questionamento e transformação radical. Para as teorias críticas o importante não é desenvolver técnicas de 
como fazer o currículo, mas desenvolver conceitos que nos permitam compreender o que o currículo faz.

Com isso, se definem e se diferenciam duas teorias curriculares com concepções opostas que, com o desenvolvimento da pesquisa, nos ajudará bastante, principalmente ao que nos concerne sobre a Implementação do currículo no estado de São Paulo, especificamente na geografia.

\subsection{Currículos tradicionais e currículos críticos em geografia}

A geografia universitária e escolar, ao longo dos últimos 40 anos, passou por profundas transformações de caráter teórico-metodológico-epistemológico, no Brasil e em vários outros países, principalmente na Inglaterra, França e Estados Unidos.

Segundo Pontuschka, Paganelli \& Cacete (2007), enquanto na universidade, na década de 1970, os debates se acirravam em decorrência da busca de novos paradigmas teóricos no âmbito do conhecimento em geografia, a escola pública de primeiro e segundo graus, hoje ensino fundamental e médio, enfrentava um problema ocasionado pela Lei 5.692/71: a criação de Estudos Sociais com eliminação gradativa da História e da Geografia da grade curricular.

As medidas legais foram tomadas pelo Conselho Federal de Educação e pelos demais órgãos superiores, em plena ditadura militar, quando a discussão dos problemas da vida do País estava praticamente ausente a pequenos círculos fechados

Elas afirmam ainda que a legislação, imposta de forma autoritária, tinha mesmo a intenção de transformar a Geografia e a História em disciplinas inexpressivas no interior do currículo e, ao mesmo tempo, fragmentar mais ainda os respectivos conhecimentos.

A geografia, neste momento, sendo considerada em sua concepção tradicional, não podia fazer mais, com essas medidas previstas em lei, um movimento de contestação baseado numa proposta mais crítica. Não poderia haver um movimento epistemológico se a disciplina nem se quer existia mais nas redes de ensino. 
A geografia crítica no Brasil surge contestando a geografia tradicional positivista e a geografia nova de fundamentação teórica neopositivista.

Os métodos e as teorias da Geografia Tradicional tornaram-se insuficientes para apreender a complexidade do espaço. A simples descrição tornou-se insuficiente como método. Era preciso realizar estudos voltados para a análise das ideologias políticas, econômicas e sociais. A parti dos anos de 1960, sob a influência das teorias marxistas, surge uma tendência crítica a Geografia Tradicional, cujo centro de preocupações passa a ser as relações entre a sociedade, o trabalho e a natureza na produção e apropriação dos lugares e territórios.

Ou seja, os geógrafos procuram estudar a sociedade mediante as relações de trabalho da apropriação humana da natureza para produzir e distribuir os bens necessários às condições materiais que a garantem. Criticou-se a Geografia Tradicional que naturalizava a ação do Estado e das classes sociais dominantes, propondo uma Geografia das denúncias e lutas sociais.

Em comum - teorização crítica do currículo e geografia crítica - apresentam uma contestação de cunho social, ambas sendo reflexos dos movimentos sociais de caráter classista, de liberdade e emancipação, que vão emergir nos anos de 1960 pela Europa e Estados Unidos. No Brasil isso aconteceu nos anos de 1970, junto com o movimento de redemocratização do país e pelo fim da ditadura militar.

O movimento de renovação da geografia terá teóricos e suas obras de referência tais como Yves Lacoste(1977), com a obra "A geografia - isso serve em primeiro lugar para fazer a Guerra", Massimo Quaini (1974) com a obra "Marxismo e Geografia" e Milton Santos (1978) com a obra "Por uma geografia nova: da crítica da geografia a uma geografia crítica". São obras com tendências voltadas para o campo da ideologia, da epistemologia e do marxismo, até então novos nesta ciência.

Segundo Vesentini (1996), o movimento de renovação da geografia está atrelado às mudanças estruturais no mundo capitalista. O sistema escolar público e obrigatório para as massas populares é em grande parte fruto da primeira revolução industrial, que se iniciou na Inglaterra em meados do século XVIII e prosseguiu até o final do século XIX. Nesse momento é priorizado o alfabetizar das massas, que incluía 
não só o aprender a ler e escrever o básico, mas também ter o mínimo de informações em matemática, história e geografia.

Já na segunda revolução industrial, que começou no final do século XIX, dois traços foram marcantes: o taylorismo e o fordismo. Um pregava o aumento da produtividade dos trabalhadores e o outro a produção e o consumo em massa. Neste momento, o sistema escolar significou, além do prosseguimento da alfabetização (o ensino público e obrigatório), uma extensão desse ensino até o nível médio e a criação das escolas técnicas. Foi uma época da valorização dos diplomas, da especialização da mão-de-obra e de cursos técnicos $\mathrm{A}$ ideia predominante era a de que se aprendia a trabalhar, ou se aprendia uma profissão na escola.

$\mathrm{Na}$ terceira revolução industrial, que são os tempos atuais, acontece uma modificação da linha de produção e gestão das indústrias. O tecnicismo abre espaço para um ideal voltado para o científico, as ideias, a criatividade nas formas de produção. A indústria de transformação cede a cada dia seu papel motor para os serviços modernos. Podemos mencionar a informática e a robótica, a biotecnologia, a microeletrônica, a química fina, as telecomunicações e as industrias de novos materiais. O ensino universitário se torna preponderante para isso.

Vesentini (1996) afirma que tais setores o fundamental são as ideias, as pesquisas, o trabalho cerebral e criativo, ficando a mão-de-obra barata e mesmo a especializada em segundo plano. É uma época em que os valores e comportamentos básicos da sociedade moderna são modificados.

Ainda em Vesentini (1996), ele afirma que o ensino da geografia atravessou de forma capenga a segunda revolução industrial, especialmente em seu apogeu, onde tal ensino foi gerado pela primeira revolução industrial, na época dos Estados-nações, juntamente com a necessidade de desenvolver o patriotismo exacerbado. Com o avanço do fordismo e em especial da internacionalização da economia, notadamente após a Segunda Guerra Mundial, essa disciplina escolar nacionalista e voltada para a memorização sofreu muito e quase não sobrevive.

Mas a terceira revolução industrial veio mudar esse quadro. Vesentini (1996) elenca dois motivos: o primeiro é que há uma revalorização das humanidades em geral 
na escola da revolução técnico-científica. Isso se dá pois já não basta mais somente os cursos ou disciplinas técnicas, como na época do fordismo e taylorismo; mas aulas teóricas e práticas que ensinem a pensar, que ajudem a desenvolver o senso crítico e o raciocínio dos educandos, auxiliando-os a aprender a pesquisar, a buscar as informações e novas abordagens.

Por outro lado, no caso específico da geografia, existe a globalização, a crescente interdependência entre todos os povos e economias, que obriga as pessoas integradas nesse processo a conhecer bem mais o mundo, os mercados externos e as diversas regiões do globo.

Mas é importante ter ressalvas nesse processo todo. Sousa Neto (1999) é enfático em afirmar que, a função do professor de geografia, e mesmo do geógrafo, não é condicionar o pensamento geográfico às regras conjunturais e históricas da terceira revolução industrial, da globalização e do neoliberalismo. E não cabe a geografia, agora adaptada às novas circunstâncias, justificar a perversidade da globalização e convencer a todos de sua inevitabilidade histórica, social e econômica.

Esse é o caminho trilhado nas concepções curriculares tradicionais (com o desaparecimento da geografia e surgimento dos Estudos Sociais em pleno período militar) e nos currículos ditos críticos (com a participação fundamental de uma universidade pública - a USP), historicamente pontuado na epistemologia da geografia e seu ensino. E que a história dos modos de produção capitalista, no mundo como um todo, juntamente com o desenvolvimento da sociedade, moldou e forjou o que entendemos hoje por geografia e seu ensino.

A seguir especificaremos as mudanças curriculares na geografia.

\subsubsection{As transformações nos currículos de Geografia}


Com as intervenções neoliberais na educação brasileira, principalmente nas décadas de 1980 e 1990, houve um movimento de renovação na geografia e, consequentemente, de seu currículo.

A AGB (Associação dos Geógrafos Brasileiros), juntamente com licenciados egressos, participavam de diversos debates entre os representantes das diferentes tendências da geografia nas universidades brasileiras. Isso, direta ou indiretamente, influíam no ensino fundamental e médio das escolas brasileiras. Nesse período, variada produção sobre o ensino da disciplina foi posta à disposição dos professores e dos responsáveis pela formação docente no país, como afirmam Pontuschka, Paganelli \& Cacete (2007)

Pinheiro (2003) faz um trabalho minucioso das pesquisas acadêmicas sobre o ensino de geografia no Brasil, entre os anos de 1972 e 2000. Ele trás uma gama de informações e reflexões sobre a geografia como disciplina escolar no Brasil, sua introdução nos currículos escolares, assim como as tendências teórico-metodológicas nas pesquisas sobre o ensino de geografia. Isso reflete um avanço na disponibilização de materiais acadêmicos para pesquisadores, professores e para o desenvolvimento geral e reflexivo da área.

Apesar desse avanço, havia uma preocupação constante quanto à mudança em sala de aula que não se efetivava. A distância entre a geografia acadêmica e a dita escolar ainda era grande. Segundo os próprios profissionais, de acordo com Pontuschka, Paganelli \& Cacete (2007), a impossibilidade de mudanças foi atribuída às precárias condições de trabalho oferecido pelas escolas, ao número elevado de horas que se viam obrigados a cumprir, ao elevado número de alunos por sala de aula e aos baixos salários.

Especialmente na década de 1980 , a produção acadêmica condizente a geografia se torna mais vasta e de qualidade, assim como os livros didáticos. Essas produções tinham como objetivo a tentativa de descobrir meios para minimizar a compartimentalização dos conteúdos escolares e a distância entre o ensino da geografia e a realidade social, política e econômica do País, ambos discutidos no âmbito da universidade. Idem (2007) 
Há de se destacar também, especialmente na década de 1990, que o debate acadêmico foi reacendido também pela implementação dos Parâmetros Curriculares Nacionais, centralizado no Governo Federal, além das Orientações Curriculares para o Ensino Médio (2002, 2004 e 2006). Cavalcanti (2002)

Com isso, como afirma Ferreira (2009), vários autores e propostas curriculares procuraram trazer para dentro da geografia escolar o papel dos conteúdos desta ciência no processo de ensino-aprendizagem.

Cavalcanti (2002) percebe que as reformas curriculares desse período apresentam convergências de caráter teórico-metodológico, distribuídas entre os diversos grupos que pensam de forma diferenciadas sobre a concepção de uma proposta oficial de ensino para a Geografia. E afirma que tais convergências são positivas na consolidação e avanço dessa disciplina na escola. Ferreira (2009) Para tal autora, Cavalcanti (2002), as características teórico-metodológicas através das quais se desenvolvem as novas propostas curriculares para o ensino de geografia são:

-O construtivismo como atitude básica do trabalho com a geografia escolar;

-A "Geografia do aluno" como referência do conhecimento geográfico construído em sala de aula;

-A seleção de conceitos geográficos básicos para estruturar os conteúdos de ensino;

-A definição de conteúdos procedimentais e valorativos para a orientação das ações, atitudes e comportamentos sócio-espaciais. (Cavalcanti, 2002:30)

Com essas convergências em pauta, o caminho curricular da geografia começa a se orientar para propostas que não só valorizem o professor como detentor de conhecimento; mas um professor como mediador desse conhecimento, valorizando o papel do aluno como sujeito do processo de ensino e aprendizagem, como afirma ainda Cavalcanti (2005:67):

Uma das características fundamentais da produção acadêmica da geografia dos últimos tempos foi o surgimento de abordagens que consideram as dimensões subjetivas e, portanto, singulares dos homens em sociedade, rompendo, assim, tanto com o positivismo como com o marxismo ortodoxo. Buscam-se explicações mais plurais, que promovam a intersecção da geografia com outros campos do saber, como a antropologia, a sociologia, a biologia, as ciências políticas, por exemplo. Uma geografia que não seja apenas centrada na descrição empírica das paisagens, tampouco pautada exclusivamente pela 
explicação política e econômica do mundo; que trabalhe tanto as relações socioculturais da paisagem como os elementos físicos e biológicos que dela fazem parte, investigando as múltiplas interações entre eles estabelecidas na constituição dos lugares e territórios. Enfim, buscar explicar para compreender. Essa tendência conceitual é a que se procurou assinalar ao definir o corpo de conteúdos que a geografia deve abordar no ensino fundamental.

Assim sendo, a renovação da geografia e seu ensino, juntamente com as diversas propostas curriculares que ocorreram no Brasil e no estado de São Paulo, valorizam as questões relativas aos conteúdos rumo a uma discussão mais pedagogizada.

É isso que veremos no capítulo a seguir.

\subsubsection{Os conteúdos e práticas curriculares de Geografia}

Delimitado a importância dos conteúdos no debate acadêmico na geografia, é relevante analisá-los em sua complexidade perante a educação escolar.

Segundo Cavalcanti (2002), os conteúdos são instrumentos para formar conceitos geográficos; e esses conceitos servem para formar um raciocínio espacial. $\mathrm{O}$ professor, como mediador e detentor de tais conteúdos, requer um desenvolvimento de uma competência crítico-reflexiva que Ihes forneça meios para um pensamento autônomo, que permita a articulação teoria e prática do ensino.

Com isso, e levando em conta que a escola é um lugar para o encontro da diversidade cultural, os conteúdos curriculares são entendidos como um conjunto de conhecimentos, saberes, procedimentos, valores que são construídos e reconstruídos no espaço da sala de aula e da escola em geral; ainda em Cavalcanti (2002). Isso numa visão socioconstrutivista.

Portanto, como indica Ferreira (2009), os conteúdos tornam-se meios para atingir determinados objetivos e não o fim em si mesmo. A preocupação está focalizada na construção de métodos que levem o aluno a pensar e ler o espaço geográfico. 
Os conteúdos da geografia escolar têm como base os resultados da ciência de referência e sua composição é constante. Segundo Cavalcanti (2005), atualmente, além de conteúdos tradicionais ainda considerados válidos, há uma infinidade de temas destacados pela geografia cujo estudo é relevante para a formação básica das pessoas, como: os processos e as formas da natureza e sua dinâmica; os impactos ambientais globais e locais; os impactos da globalização na produção de lugares diferentes e desiguais; os conflitos socioespaciais na suas diferentes escalas, como a violência urbana de diferentes naturezas e proporções, conflitos como que ocorre entre Palestina e Israel, entre o Movimento dos Sem Terra e proprietários rurais no Brasil, etc.

Há de se estar atento a isso, pois, de certa forma, esta perspectiva que parece crítica, em realidade pode reproduzir certas ideologias pós-modernas próprias da apropriação construtivista centrada nos indivíduos e não em suas relações sociais e condições de classe.

Dito isso, Cavalcanti (2010) ressalva que o objetivo da construção desses conceitos, por estarem associadas a uma determinada atitude no ensino, não podem ser vistos isoladamente; ao contrário, todas as ações docentes concretas devem ser realizadas de modo inter-relacionado e interdependente entre si e coerentes com aquela atitude. Elas fazem parte, por assim dizer, de uma atitude global e devem ser tomadas no ensino no momento que se julgar adequado, dependendo dos propósitos e das condições concretas de sua realização.

E vai além afirmando que o construtivismo piagetiano não pode ser interpretado como uma promoção da construção individual do aprendizado, na crença de que os alunos constroem esse conhecimento apenas pela exploração e pesquisa e na ênfase excludente nos seus processos construtivos espontâneos.

Os temas mesmo com grande relevância precisam ser refletidos, na figura do professor, como mediador do processo, avançando além dos fatos. E isso é somente parte do processo de aprendizagem.

E Cavalcanti (2007) apresenta, de uma forma oposta à tradicional, a necessidade de o ensino da geografia contribuir para o desenvolvimento do aluno 
dentro de um modo geográfico de pensar sobre o mundo e a realidade que nos cerca. Para tanto, não basta apresentar os conteúdos geográficos para que os alunos o assimilem, mas sim trabalhar e desenvolver esses conteúdos, realizando o trabalho didático, para que se transformem em ferramentas simbólicas do pensamento.

Os conteúdos não são apenas pretextos para o desenvolvimento que se pretende e não podem ser assim encarados, pois são fatos, acontecimentos, fenômenos geográficos importantes em si mesmos.

Assim sendo, o papel do professor e sua formação contínua é essencial para o tratamento dessas práticas de aula. O planejamento, o registro e a avaliação das aulas precisam ser constantes e bem pensadas, articulando a forma, o conteúdo e a dinâmica escolar.

Com isso, é de extrema urgência um debate sobre a real necessidade de autonomia do professor e de todo processo de ensino e aprendizagem nas escolas.

Como a sala de aula ainda é o espaço privilegiado do trabalho do professor, assim como sua prática docente e a transposição de conteúdos e temas, a seleção de conteúdos é encarada como fundamental para se alcançar um resultado baseado na significação do conhecimento junto aos alunos.

Paganelli (2002) afirma que a seleção e organização de conteúdos e dos conceitos constituem um item de todo e qualquer Planejamento Curricular de Ensino.

Continua dizendo que uma seleção tem, como pressuposto, o domínio pelo professor de geografia dos conhecimentos da ciência geográfica, associada à compreensão das principais correntes do pensamento geográfico, enfoques, categorias, conceitos básicos e a evolução da própria disciplina escolar; conhecimentos que permitem que se situe, em sua prática pedagógica, numa opção metodológica mais coerente.

Um professor, sujeito desse conhecimento, e não simplesmente transmissor, é capaz de enfrentar, com êxito, a seleção de conteúdos e sua organização em um planejamento escolar, facilitando a apropriação do conhecimento e do pensar geográfico. 
Ao longo dos últimos vinte anos, há uma nova forma de tratar os elementos geográficos e seu ensino. Com um debate constante e contínuo, tanto nas universidades quanto nos órgãos representativos da área, tem levado a profissionais ligados a educação repensarem novas práticas pedagógicas.

Entender o vivido, a produção do espaço, o lugar, o território, entre outros, além de uma proposta meramente conceitual, através de uma prática sistematizada de ensino e aprendizagem é recorrente e necessário.

Muitos professores ainda desconhecem essas novas propostas metodológicas, e que muitas propostas curriculares são bem embasadas, porém, na prática, adotam um ensino tradicional.

A partir disso, há de se ter uma reflexão sobre as transformações do ensino básico em geografia. E é isso que veremos adiante.

\subsubsection{Relações na transformação da realidade do ensino público básico de Geografia}

Uma das questões centrais, a que nos interessa nesse momento, seria as mudanças na realidade do ensino público no Brasil, especialmente no estado de São Paulo. Num outro momento, relacionaremos com a realidade do ensino de geografia, proposta central desse trabalho.

Segundo Pontuschka, Paganelli \& Cacete (2007), mudanças significativas ocorreram no universo educacional brasileiro como fruto das discussões para a promulgação da LDB/96, e, na década de 1990, as propostas curriculares dos estados foram debatidas com a finalidade de gerar nova proposta, agora com o nome de Parâmetros Curriculares Nacionais.

Num período de implantação neoliberal e consolidação do poder de sociais democratas (governos FHC e Mário Covas), a política educacional brasileira e paulista vai se redefinindo em iniciativas tais como a criação dos PCNs e de um sistema 
nacional de avaliação, colocada em prática através do ENEM (Exame Nacional do Ensino Médio) e do conhecido Provão (Ensino Superior), juntamente com o Programa Nacional dos Livros Didáticos (PNLDs).

Como consequência social e educacional, enquanto que maximizava o econômico, há uma clara manutenção do capital como prioridade.

Segundo Rocha (2001), neste período saiu um projeto que, de um lado, atribuía ao Estado e à esfera pública a culpa por todos os males sócio-econômicoculturais apresentados no atual momento histórico e, por outro, considerava a iniciativa privada como sendo a panacéia, capaz de reverter todas as agruras do mundo contemporâneo.

Vai além afirmando que o que saiu vencedor não foi um projeto brasileiro, mas sim um projeto para o Brasil, produzido fora do País e integrante de um processo que só pode ser compreendido quando inserido no interior de um conjunto de ações de caráter global, como afirmamos no primeiro capítulo.

Em fevereiro de 1995, quando do lançamento do programa Acorda Brasil está na hora da escola, as cinco prioridades anunciadas no governo do então candidato Fernando Henrique Cardoso eram transformadas nas metas educacionais do novo gestor.

Segundo Rocha (2001), o documento anunciava que as atenções governamentais estariam voltadas para a implementação das seguintes políticas:

- Distribuição das verbas federais diretamente para as escolas, sem intermediação dos governos estaduais e das prefeituras;

- criação do sistema Nacional de Educação a Distância para treinamento de professores e complementação das aulas, através de TVs e vídeos em todas as escolas;

- melhoria da qualidade dos 58 milhões de livros didáticos, distribuídos todo ano pelo Governo e fim dos atrasos na distribuição, a partir do segundo ano do governo;

- avaliação das escolas, por meio de testes aplicados aos alunos, com premiação daqueles que apresentarem melhor desempenho; 
- reformado currículo para melhorar o conteúdo do ensino, com o estabelecimento das matérias obrigatórias para todo o país.

Estas propostas mostram claramente os ideários neoliberais, num governo que, desde seu início, tinha intenções claras em relação aos destinos de nosso país.

Seguindo na mesma direção, no estado de São Paulo é instituído o SARESP (Sistema de Avaliação de rendimento Escolar do Estado de São Paulo).

Pontuschka, Paganelli \& Cacete (2007) define esse conjunto de propostas, medidas e ações como um pacote com o objetivo de se observar que há, por parte do governo federal, uma clara intenção de implantar um novo perfil à educação brasileira.

As autoras afirmam também que a mudança é necessária, mas da forma como foi conduzida fez com que algumas das propostas, medidas e ações estejam ou estiveram sendo encaminhadas com uma urgência que conduz e limita o debate, impedindo, muitas vezes, o estabelecimento de uma reflexão mais consistente. $E$ mais do que isso: uma avaliação que impõe o currículo.

Considerando os PCNs norteadores das ações curriculares em dado sistema de ensino, ou mesmo em dada escola, daremos um certo destaque a esses parâmetros.

Elaborado pelo governo federal, atrelado a discussão e consolidação da LDBN/96, os PCNs, juntamente com as DCNs (Diretrizes Curriculares Nacionais) têm por objetivo propiciar subsídios à elaboração e reelaboração do currículo, tendo em vista um projeto pedagógico que se pretende em função da cidadania do aluno e uma escola em que se aprende mais e melhor.

As premissas centrais de tais parâmetros são criar tais subsídios para apresentar ideias do "que se quer ensinar", "como se quer ensinar" e "para que se quer ensinar". Assim são definidas também as capacidades e habilidades esperadas dos alunos, assim como os conteúdos a serem trabalhados em cada disciplina escolar.

Mas por que centralizar uma política que poderia ser descentralizada, irradiando as responsabilidades aos estados e municípios?

Segundo Spósito (1999), esse debate é necessário pois a tendência nesse momento, até respaldado pela Constituição, é de um processo que conduz ao aumento 
das responsabilidades dos estados e municípios na implantação e gerenciamento dessa política educacional.

Revela-se, assim, de forma clara uma contradição, onde há uma política de descentralização, cuja condução está se dando de forma muito centralizada. Algo que, talvez, como indica Spósito (1999), possamos denominar de descentralização centralizada.

Em princípio, isso pode ser justificado, na medida em que a descentralização, quanto mais intensa ela for, exigiria diretrizes gerais básicas, de forma a garantir o mínimo de qualidade e equivalência nacional no ensino que se pratica em todo o país ou, em outras palavras, uma política de centralização das decisões e parâmetros gerais que conduziriam à descentralização.

Vale ressaltar também que tais mudanças e propostas ocorrem num período em que o governo propunha, em seu discurso, a participação mínima do Estado na condução da economia e do país, como denota a política de privatizações iniciada por Fernando Collor de Melo e acelerada por Fernando Henrique Cardoso.

Mas, como consequência disso, sucintamente indagando, Spósito (1999) coloca que as disparidades no interior da sociedade colocam em questão a política de descentralização centralizada, pois são notáveis as enormes diferenças entre as grandes regiões, os estados e municípios brasileiros.

Isso indica a dificuldade de referenciais nacionais para a redefinição de política educacional, quer no que se refere às formas como se deve conduzir o processo de ensino-aprendizagem e escolher os conteúdos a serem trabalhados, quer no que diz respeito à disponibilidade de recursos humanos qualificados para tal.

Os PCNs de geografia são analisados assim por Pontuschka, Paganelli \& Cacete (2007:75):

Os Parâmetros Curriculares Nacionais ( $\mathrm{PCNs}$ ) de geografia para o ensino fundamental propõem um trabalho pedagógico que visa ampliar as capacidades dos alunos de observar, conhecer, explicar, comparar e representar as características do lugar em que vivem e de diferentes paisagens e espaços geográficos. Inicialmente, dão a conhecer, segundo visão de seus autores, a trajetória da disciplina em pauta, a geografia, como ciência e como disciplina escolar. Nas orientações para o trabalho pedagógico, são apresentados os objetivos, os eixos temáticos, 
os conteúdos e os critérios de avaliação. Ao final, o documento traz indicações sobre a organização do trabalho escolar, referindo-se aos processos metodológicos.

Tais PCNs aparecem num momento em que, na década de 1980, os estados da federação, incluindo São Paulo, elaboravam suas próprias propostas curriculares. De modo geral, tais propostas ditavam os conteúdos que deveriam estar presentes nas aulas e nos planos de aula dos professores, incluindo os de geografia. Na prática, funcionaram não essencialmente como parâmetros, mas sim como currículos manifestos que, por estarem dentro da institucionalização da avaliação, obrigavam ao invés de recomendar.

Os autores de livros didáticos, segundo Pontuschka, Paganelli \& Cacete (2007), pautavam-se pela organização dos conteúdos apresentados pelas Secretarias de Educação e dos municípios para elaborar seus textos.

Nessa mesma época, em São Paulo, a Coordenadoria de Estudos e Normas Pedagógicas (CENP) constituiu uma equipe de autores para a realização de propostas curriculares para todo o estado. Não se propunham somente elaborar um rol de conteúdos, mas sobretudo efetuar uma revisão metodológica com amadurecimento dos princípios fundadores da disciplina, iniciativa conhecida, na época, como geografia crítica.

A discussão da proposta, embora não tenha atingido a todos, promoveu uma ruptura no ensino tradicional da disciplina, apontando caminhos diferentes de um ensino apenas transmitido pelo professor, descolado dos movimentos sociais e da realidade social do país, como apontam Pontuschka, Paganelli \& Cacete (2007)

Isso é avaliado como avanço. Mas não teve como evitar o estranhamento dos professores do estado de São Paulo quanto ao aparecimento dos PCNs e dos novos métodos recomendados.

Sem dúvida, a realidade das escolas brasileiras têm tido muitas orientações e poucas ações que as consolidem. No estado de São Paulo, berço dos governos direitistas que, por coincidência ou não, estiveram atrelados ao governo federal, a realidade regional tornou-se um referencial e um modelo de implementação de diversas propostas curriculares. 
Até então descentralizadas, as políticas estaduais para a educação tinham seu caminho próprio; seja em processos que realmente atingiram seus objetivos e aqueles que não. Agora existe uma centralização que, de certa forma, recomenda obrigando os estados a seguirem tais normas formuladas pelo governo federal. Ou mesmo propostas construídas regionalmente, mas que são influenciadas por diretrizes e normas que regulamentam um caminho a seguir dentro de um currículo.

Especificaremos a seguir o caso do estado de São Paulo, foco desse estudo.

\section{CAPÍTULO 3}

\section{A organização da proposta curricular de ensino da rede estadual paulista}

A partir de 2007, sob o comando do governador José Serra e da Secretaria de Educação Maria Helena Castro, implementa-se uma nova proposta curricular para o Estado de São Paulo. 
O presente capítulo visa analisar essa nova proposta em sua totalidade, buscando compreender os motivos pelos quais a mesma se impõe dentro de um quadro mais amplo de inserção de uma política neoliberal para a educação em São Paulo, de modo singular, e como a parte referente à geografia se encaixa epistemologicamente nessa proposição.

Com isso, reforçar a construção de uma leitura do mundo, mais ideologicamente comprometida com a lógica de reprodução ampliada do capital no contexto de sua crise estrutural.

Entre 1997 e 2002, o método pautado para implementação e regulamentação desse currículo está baseado em experiência realizada no âmbito da esfera federal, no governo do até então presidente Fernando Henrique Cardoso, como afirma Freitas (2009:60):

Ao lermos a proposta para a educação do estado de São Paulo formulada pelo governo José Serra é surpreendente que nada tenha mudado desde que, pela primeira vez, este mesmo grupo a formulou para o governo federal na década neoliberal, nos anos 90, sob a administração de Fernando Henrique Cardoso, tendo Paulo Renato Costa Souza como Ministro da Educação.

Ao não conseguir fazer o sucessor de Fernando Henrique Cardoso no governo federal, boa parte dos ministros foram Secretários de Estado de São Paulo, a exemplo de Paulo Renato Costa Souza ${ }^{12}$ que, em 15 de abril de 2009, dando continuidade a essa política educacional ${ }^{13}$ na pasta.

Com a construção e eventual implementação do novo currículo, muitos documentos foram formulados pelo Estado, através da SEE-SP, para uma

\footnotetext{
${ }^{12}$ Sanfelice;Minto \& Lombardi (2009:52): “À frente do MEC, Paulo Renato sempre demonstrou seguir à risca as orientações do Banco Mundial, numa tradução das políticas neoliberais para a educação. Com relação à educação básica, dois grandes projetos foram levados a cabo neste processo: a municipalização forçada do ensino fundamental com a nova forma de distribuição dos recursos da educação (FUNDEF), e que, segundo Paulo Renato, visava estimular uma 'competição' entre Estados e municípios pelos recursos; e a introdução de uma polítca que tomava como único parâmetro de qualidade a melhoria das estatísticas educacionais". A partir de 1996, ano de "aprovação" da LDB, é perceptível um processo de "descentralização centralizada" do sistema educacional no Brasil.

${ }^{13}$ Para Saviani (2009) política educacional consiste na direção da sociedade quanto aos aspectos da educação, em geral, e da educação escolar especificamente. Implica a definição, a execução e o controle do cumprimento de leis, normas, objetivos, metas para a educação. Relaciona-se, necessariamente, à política mais geral da sociedade. E, como ela, define-se e realiza-se em meio a processos de disputas e negociações, que refletem os diversos interesses em jogo. Na mesma lógica, as políticas curriculares dizem respeito às relações que se estabelecem na tomada de decisões sobre o currículo escolar: as normas, diretrizes, orientações para elaboração, execução, controle, avaliação.
} 
institucionalização curricular mais abrangente, abrindo portas para a implementação de tal projeto curricular.

O que aparece como documento central de nossa análise é a proposta curricular do estado de São Paulo no ensino de geografia, norteador inicial das ações no ensino e aprendizagem como um todo, bem como de modo particular da disciplina geografia.

A observação e discussão sobre o que são esses documentos, quais suas propostas reais, pedagógicas, de viabilização na rede e da avaliação de seus resultados teóricos e práticos são uma condição prioritária para se entender tal reforma educacional.

O estudo desses documentos, com uma explicitação do atual panorama da rede de ensino, adentrando nas possibilidades de um modelo curricular já praticado no Brasil é o que buscaremos realizar nesse capítulo.

Saviani (2009) afirma que as políticas curriculares podem ser feitas mediante o exame de diversos materiais, com destaque para: a legislação e os documentos oficiais correspondentes; as peças de interpretação da legislação (jurídicas ou teóricas, em caráter técnico ou político, provindas de especialistas, ativistas e da opinião pública em geral, expressas inclusive, em matérias jornalísticas); o rol de matérias escolares, sua distribuição pelos níveis de ensino, carga horária, programas (quadro curricular/plano de curso); os regimentos comuns e específicos; a documentação da vida estudantil (histórico escolar); as determinações legais quanto às funções e características do corpo docente; os programas de formação (inicial e continuada) de professores e especialistas; os livros, manuais e outros recursos didáticos.

Com isso, analisaremos, em parte, as condições e debates em torno dessa proposta curricular, adentrando mais especificamente no estudo do ensino de geografia.

\subsection{Um panorama da rede estadual de ensino de São Paulo}


A rede estadual de ensino do estado de São Paulo é a maior do Brasil, que, segundo dados do Censo Escolar do INEP ${ }^{14}$ (Instituto Nacional de Estudos e Pesquisas Educacionais), conta com 5.495 escolas, num universo de 390.337 professores, incluídos nestes 100.190 não efetivados por concurso. Quanto aos funcionários, a estrutura da SEE, incluindo as escolas, é composto de 50.000 pessoas, divididos em cargos administrativos, técnicos e de apoio escolar. ${ }^{15}$ As escolas estão distribuídas pelo estado todo, onde os professores estão lotados em diferentes níveis e modalidades de ensino, da creche ao ensino técnico ${ }^{16}$.

\section{Quadro 3}

\section{As quatro maiores e as quatro menores redes estaduais de ensino público do Brasil (2010)}

\begin{tabular}{|l|l|l|}
\hline Estados & $\mathbf{N}^{\mathbf{0}}$ de alunos & $\mathbf{N}^{\mathbf{0}}$ de Professores \\
\hline São Paulo & 4.152 .685 & 390.337 \\
\hline Minas Gerais & 2.116 .691 & 215.928 \\
\hline Bahia & 908.817 & 152.648 \\
\hline Rio de Janeiro & 894.765 & 143.029 \\
\hline Tocantins & 137.312 & 17.583 \\
\hline Acre & 135.843 & 10.576 \\
\hline Amapá & 125.952 & 9.566 \\
\hline Roraima & 75.034 & 6.207 \\
\hline Brasil & 17.218 .673 & 1.977 .978 \\
\hline
\end{tabular}

Fonte: INEP - CENSO ESCOLAR (2010)

A quantidade de escolas da rede vem diminuindo substantivamente durante os anos, com a extinção de unidades de ensino (com a alegação, na maioria das vezes, da falta de demanda) e a municipalização do ensino fundamental I.

\footnotetext{
${ }^{14}$ Fonte: http//www.inep.gov.br. acessado em 20/01/2011

${ }^{15}$ Fonte: http//www.educacao.sp.gov.br. acessado em 21/01/2011

${ }^{16}$ Ainda segundo o INEP, esses professores estaduais estão distribuídos da seguinte forma: cerca de 55.000 como Professor de Educação Básica I (PEB I) e 163.000 como Professor de Educação Básica II (PEB II), nas diversas modalidades de ensino que compreendem a educação infantil (creche e pré-escola), o ensino fundamental I e II, o ensino médio (com o EJA, o normal e o técnico), além da educação especial (alunos de escolas especiais, classes especiais e alunos incluídos).
} 
Com a criação do FUNDEF (Fundo Nacional de Desenvolvimento da Educação Fundamental) em 1996, as prefeituras tiveram um volume maior de recursos e conseqüente aumento no número de matrículas. Esse montante de egressos da rede municipal são direcionados para as escolas estaduais (principalmente no Ensino Médio), indo na contramão da falta de expansão da rede estadual (aumento da demanda) e repasse de responsabilidades dos ensinos fundamental I e II para as prefeituras.

Existe uma política que evidencia o déficit/ausência de professores, onde, a rede, através da exploração, precarização e desmonte do trabalho docente, não efetiva grande parte dos professores, levando a uma busca desenfreada por aulas, ano a ano, não garantindo assim o emprego de muitos ao final do ano letivo.

As contratações de professores na rede estadual paulista são feitas da seguinte forma: através de concursos (metade do total de professores), os estáveis garantidos pela Constituição de 1988 , os estáveis celetistas e as contratações temporárias, regidas pela Lei $500 / 74$ ( $40 \%$ do total de professores), que agora foram divididos em categorias como $\mathrm{F}, \mathrm{O}$ e L. Os Fs são semi-estáveis, tendo garantia de no mínimo 10 aulas, e mesmo não tendo as aulas disponíveis, são designados para trabalhos burocráticos. As categorias $\mathrm{O}$ e L (pasmem) podem dar aula se elas estiverem disponíveis por 200 dias letivos, tendo um pedágio de 200 dias sem poder dar aula. Todos os temporários têm obrigação de fazer uma prova classificatória todo ano, excluindo a $F$ que não tem essa obrigatoriedade. A atribuição segue essa ordem classificatória, sendo os efetivos e estáveis primeiros, depois os das categorias $F, L$ e $O$ (que passaram na prova) e $F$, L e O (que não passaram na prova).

Essas formas de contratação explicitam não só a precarização do trabalho docente, mas o estímulo à desunião da categoria e a quebra da profissão. Isso está produzindo um profundo estranhamento entre os trabalhadores, que não reconhecem a si como defensores de uma condição que os qualifique, desqualificando-os como sujeitos realizadores de uma ação social ativa e histórica.

Com isso e além disso, há uma substantiva escassez de professores em algumas áreas (como física, química e sociologia) e a processos burocratizantes de 
atribuição de aulas, onde os professores temporários, não sendo fixos nas escolas que trabalham, ficam condicionados a incertezas quanto a sua contratação.

Ainda numa outra perspectiva, professores formados em certas disciplinas são obrigados a lecionar àquelas onde não há professores, e para as quais não foram formados, não tendo um preparo intelectual específico da disciplina.

Mesmo com o número grande de temporários, algumas regiões não alcançam o número suficiente de profissionais por sala de aula, gerando um déficit no aprendizado dos alunos.

Assim, com todos esses dados já conhecidos pela SEE, tal órgão estabelece uma prova eliminatória para a classificação e permanência ou não dos profissionais na rede.

Isso dificultou cada vez mais a questão da falta de professores e da atratibilidade profissional docente, onde, grande parte deles, há anos prestando serviços para o Estado, convivem com péssimas condições de trabalho, salário e formação profissional.

Com isso, há um envelhecimento do quadro de professores, sem perspectiva de renovação. Isso gera uma situação insustentável na formação educacional paulista com uma baixa procura pelo jovem formado pelas universidades.

Com uma rede desse tamanho, e com os seguidos equívocos na formação dos professores $^{17}$, a SEE tem um desafio enorme na melhoria de qualidade da educação, mesmo porque não consegue nem sequer ter um quadro fixo de trabalhadores, ou seja, nem o fator quantitativo é contemplado no processo educativo.

A questão salarial também é um assunto inerente a isso. Os salários são muito defasados em relação a outros cargos de nível superior, mostrando o descaso do atual governo em relação à importância estratégica, para um país, de profissionais dessa ordem.

Há uma política de bônus e de meritocracia embutida na questão salarial onde, com as avaliações externas, são medidos os desempenhos do trabalhador e da escola,

\footnotetext{
${ }^{17}$ Sarno; Cancilliero (2009:12): "Em 2000, a Secretaria do estado da Educação de São Paulo (SEE/SP), adotou uma proposta de formação de professores por meio de atividades preferencialmente à distância, minimizando a importância da relação professor-estudante e do diálogo presencial, ou seja, dificultando a construção de processos de ensino e aprendizagem que possibilitam ao professor a aquisição de autonomia para formular leituras de mundo e atuar enquanto sujeito histórico, fortalecendo seu compromisso com a profissão." E esta proposta continua até os dias de hoje.
} 
através de índices que supostamente quantificam e qualificam os aprendizados dos alunos. Um plano de carreira consistente, aberto a reflexões e debates democráticos com a categoria praticamente inexiste.

Com isso, há uma destruição da carreira docente em evidência, chegando até a abolição de direitos adquiridos, como as condições previdenciárias, o não cumprimento por parte do governo das datas base, com a consequente falta de reajuste no salário, mascaradas por políticas de bonificação ligadas ao mérito, não reposição dos índices inflacionários anuais, assim como uma não vinculação dos ganhos em relação ao salário mínimo, diminuindo ano a ano o poder de compra da categoria.

$\mathrm{Na}$ questão administrativa ${ }^{18}$ existe a mesma precariedade. Muitos diretores são temporários, não permanecendo sequer numa mesma unidade escolar. Quanto aos vice-diretores, indicados pelo diretor, gera a mesma instabilidade e incerteza

Não existe uma carreira pedagógica na administração escolar. Assim como o vice-diretor, não existe um cargo para o coordenador pedagógico, sendo limitado a designação de um professor ${ }^{19}$, num processo que envolve uma entrevista e um projeto pedagógico que muitas vezes não é posto em prática na escola. Isso pode gerar relações muito clientelistas no interior da escola.

É apenas uma função onde, por diversas vezes, o professor não sabe executar, independente das precárias formações de gestão escolar nas diretorias de ensino.

Quanto aos funcionários administrativos e de apoio escolar a realidade é de uma precariedade, refletido num déficit de funcionários. Os chamados inspetores de alunos e técnicos administrativos são bastante raros. Aqueles que existem são contratados de forma precária, através de cooperativas ${ }^{20}$, processos seletivos com contratos prédefinidos, com baixíssimos salários, ou terceirizados (na grande maioria na área de limpeza e merenda).

\footnotetext{
${ }^{18}$ Gestão no sentido da organização estrutural, pedagógica e de recursos humanos dentro de uma dada unidade escolar, diferenciando da gestão utilizada muito no mercado financeiro, assim como em organizações capitalistas que visam lucros. Neste caso, equipe gestora é composta de diretores, vice-diretores e professores coordenadores pedagógicos (PCP)

${ }^{19}$ Único pré-requisito para um professor se tornar coordenador é o tempo de serviço. Não existe a obrigatoriedade de ser pedagogo.

${ }^{20}$ Esse tipo de contratação foi cancelada devido a irregularidades apontadas pelos órgãos competentes. Não houve substituição suficiente de funcionários nessa área. Os poucos concursos realizados são temporários, com salários extremamente defasados e sem perspectiva nenhuma de consolidação dos funcionários em tal função.
} 
A infra-estrutura das escolas deixa a desejar, onde, dependendo do lugar, há um investimento, mas não um acompanhamento, assessoramento e formação para a utilização de novos espaços de aprendizagem, de novas tecnologias para a educação.

É com uma realidade dessas que a rede estadual de ensino do estado de São Paulo caminha. Há um desmonte da escola pública, com a precarização do trabalho e a conseqüente desqualificação do ensino-aprendizagem em todos os níveis de ensino.

\subsection{Apresentando a proposta curricular da rede estadual de São Paulo o documento}

A Proposta Curricular do Estado de São Paulo foi elaborada sob o discurso de melhorar a qualidade de ensino do estado em questão por meio de um currículo único e com material delimitado e determinado para o professor, para o administrador escolar e o aluno, mas estruturalmente segue os ideários neoliberais desenvolvidas pelo Banco Mundial como já caracterizado.

Concebido pelos especialistas da educação ligados a SEE, com sua estrutura pedagógica (CENP, FDE - Fundo de Desenvolvimento da Educação, ONGs Organizações não governamentais e parcerias) ${ }^{21}$, muitos desses escritores de livros didáticos estão distantes a muito tempo da sala de aula ${ }^{22}$.

Como análise central dessa proposta, está o documento intitulado "Proposta Curricular do Estado de São Paulo - Geografia: Ensino Fundamental - Ciclo II e Ensino Médio".

A execução desse material teve como coordenadora geral Maria Inês Finni e a concepção ficou a cargo de Guiomar Namo de Mello, Lino de Macedo, Luís Carlos de Menezes e Ruy Berger, além da própria Finni. A produção foi responsabilidade da Fundação Carlos Alberto Vanzollini, juntamente com a CENP e a FDE.

\footnotetext{
${ }^{21}$ CENP (Coordenadoria de Estudos e Normas Pedagógicas do estado de São Paulo); FDE (Fundação para o Desenvolvimento da Educação); ONG (Organizações não governamentais).

${ }^{22}$ Ibidem (2009:12) "Nesse período (2000-2009, junto a SEE-SP), adotou-se a prática de iniciar projetos elaborados por técnicos de gabinete e abandoná-los sem qualquer avaliação dos educadores que trabalham na rede estadual pública e de ensino. Essa postura, adotada pelos sucessivos governos, permanece até hoje.”
} 
O interessante a salientar é que Maria Inês Finni, professora aposentada da Faculdade de Educação da Unicamp, é da mesma instituição onde a ex-secretária da educação do estado de São Paulo Maria Helena Guimarães estudou e fez carreira acadêmica.

Guimarães foi coordenadora geral e presidenta do INEP na gestão FHC; e tendo como ministro da educação Paulo Renato Souza. Com a saída de Renato do ministério, ao fim da era FHC, é fundada a PRS Consultores, empresa de consultoria de Paulo Renato especializada na "Indústria do Conhecimento".

Segundo Sanfelice;Minto;Lombardi (2009) figuras emblemáticas da política educacional paulista compõem o quadro de "consultores" que trabalham para a PRS, com grande influência em setores do Banco Mundial como a antiga Secretária Maria Helena Guimarães Castro e Maria Inês Finni.

É importante apresentar uma conclusão que mesmo antes de ser Secretário da Educação de São Paulo, Paulo Renato de Souza já tinha amplos poderes junto a essa pasta, com suas seguidoras oriundas de sua universidade de origem, a UNICAMP (Universidade de Campinas), e dos anos neoliberais de $\mathrm{FHC}$, sempre junto à estrutura do MEC.

Os outros autores aparentam algumas características mais técnicas, como Lino de Macedo, professor da Faculdade de Educação da USP (Universidade de São Paulo) e Luís Carlos de Menezes, professor do Instituto de Física da USP. Contudo sempre sendo encontrados nas entranhas do poder, principalmente aos governos ligados ao PSDB, onde Lino sempre assessorou a SEE e Menezes é articulista da revista Nova Escola, ligada ao grupo Abril. Coincidentemente, tal grupo editorial mantém parceria de assinaturas com a SEE.

Já Guiomar Namo de Mello é empresária da educação, professora da PUC-SP, sendo uma das fundadoras do PSDB e ex-secretaria da educação na gestão Mário Covas na cidade de São Paulo.

Em 1990 e 1991 foi consultora da preparação de projetos do Banco Mundial de investimento em educação na região Nordeste e no estado de Minas Gerais. Trabalha essencialmente com bases teóricas oriundas de concepções educacionais voltadas 
para o ensino básico, tais como os Parâmetros Curriculares Nacionais, educação para a cidadania, mudanças estruturais na escola e na sociedade, formação de professores e educação à distância e as novas tecnologias.

O professor Ruy Berger foi Secretário de Educação Média e Tecnológica do MEC, também no governo FHC.

Percebe-se então, a partir dessa breve apresentação dos autores, a estratégia de um grupo, que há décadas está implementando políticas públicas para a educação, sempre ligados a universidades públicas e aos governos vigentes, num tempo histórico onde as políticas invasivas de órgãos multilaterais estavam em plena implementação em nosso país. Todos os autores em questão são ligados direta ou indiretamente ao conservadorismo pregado por uma ideologia de direita representada pelo PSDB.

A insistência em contextualizar tais intelectuais colonizados desse documento e da proposta curricular como um todo é de demonstrar, de uma forma sucinta, mas reveladora, que as condições técnicas desses especialistas são mero pretextos para levar a política pública para a educação de uma forma bastante politizada, voltada para os ideais neoliberais.

Existe um discurso de educação voltado para a cidadania, para a qualidade da educação, para a flexibilidade curricular, mascarados pela acumulação do capital e pela implementação do neoliberalismo na educação brasileira. Termos que ostentam melhorias, mas que, na verdade, ocultam a verdade dos fatos e são voltados para o capital.

Contextualizado seus autores, o documento trás, logo de início, uma carta voltada para os gestores e professores, apresentando e justificando o novo currículo. A Proposta Curricular do Estado de São Paulo ${ }^{23}$ (2008) afirma que a criação da Lei de Diretrizes e Bases (LDB), que deu autonomia às escolas para que definissem seus próprios projetos pedagógicos foi um passo importante, mas ao longo do tempo, porém, esta tática centralizada-descentralizada mostrou-se ineficiente.

Vejo nesta afirmação uma pura divergência política Estado-União, em momentos de discussões eleitorais para a presidência, onde a LDB é criticada no ponto

\footnotetext{
${ }^{23}$ A partir desse momento, em todas as citações referentes à Proposta Curricular do estado de São Paulo vamos usar
} a nomenclatura PROPOSTA. 
de vista da operacionalidade curricular, mas os conteúdos ainda são inspirados por essa mesma LDB e os PCNs.

Outra afirmação nesta carta é considerar que o currículo ter sido discutido em toda rede e que está em constante evolução e aperfeiçoamento. Isso é uma falsa afirmação como encontrado em Sarno;Cancelliero (2009:13):

O fato de o Estado de São Paulo não ter ainda um Plano estadual de Educação reforça o argumento de que os diferentes governos do período estudado optaram por um projeto de educação que não privilegia objetivos, diretrizes, metas, aplicação de recursos transparentes e de acesso a todos. E, também, uma das razões indicativas de que o projeto do atual governo (2007-2010) não considera a educação como um instrumento de formação ampla, de luta pelos direitos da cidadania e da emancipação social, condições essenciais para o preparo de cidadãos responsáveis por construir, coletivamente, um projeto de educação inclusiva e de qualidade social para todos.

Vemos aqui, logo de início, uma tentativa de ludibriar os agentes escolares com fatos que não condizem com a verdade como afirma Sarno;Cancilliero (2009:15):

Ao se analisar a forma como foi implantado a Proposta Curricular de estado de São Paulo para o Ensino Fundamental e Médio, por meio da consulta ao professor via Internet e treinamento por vídeoconferências, pode-se afirmar que ela traz no seu bojo uma concepção de profissional distante. O entendimento equivocado a respeito do papel do professor e do gestor (diretor de escola e professor coordenador) e do supervisor de ensino, desde sua elaboração, implantação e avaliação, desvenda a concepção de currículo contida na Proposta Curricular, muito distante daquela que vê o currículo como necessariamente resultante da construção coletiva, fundamentado na análise crítica da realidade social e com mecanismos de constante atualização, inclusive, por meio da incorporação das práticas escolares, das ações individuais e coletivas necessárias à solução dos problemas vivenciados.

Partindo do princípio exposto por Bezerra Neto, Bezerra e Jacomelli (2009), que a escola é uma instituição que está presente em todas as sociedades modernas e, como tal, tem uma relevância muito grande na formação das novas gerações, temos que pensar se queremos manter o status quo desta sociedade ou se estamos dispostos a lutar para transformá-la. 
Em decorrência disto, o Governo do estado de São Paulo nos apresenta esse currículo.

O currículo deve ser sempre situado no tempo e no espaço e responde aos interesses da classe ou dos grupos que controlam o Estado, dado que ele não é metafísico, fora de uma realidade social concreta. Sabendo disto e aparentando dar o currículo à importância que ele deve ter, o Governo estadual resolveu apresentá-lo.

$\mathrm{Na}$ apresentação do currículo à sociedade, o Governo do estado de São Paulo parte do reconhecimento dos princípios amplamente difundidos de que neste momento, em que a economia e a comunicação estão globalizadas, a nossa sociedade atingiu o seu ideal, sendo esta única realidade imaginável a qual devemos nos adequar, nos preparando para nela viver da melhor maneira possível. Como afirma Bezerra Neto;Bezerra;Jacomelli (2009:38):

Ao assumir esta concepção deveras conformista e determinista, os detentores do poder entendem que já atingimos o melhor da sociedade e não precisamos transformá-la, restando-nos apenas a condição de nela conviver adaptandonos, em outras palavras, aprendendo a conviver com as desigualdades, neste caso, entendidas como diferenças.

Mas, incrivelmente, essa proposta não é pautada no professor, e sim na chamada equipe gestora, composta por diretores, vice-diretores e professores coordenadores. O documento chega a afirmar que a função do professor coordenador é animar os professores para a implementação da proposta, assim como "responsabilidade da equipe gestora como formadora de professores e a responsabilidade dos docentes, entre si e com o grupo gestor, na problematização e na significação dos conhecimentos sobre sua prática" (Proposta 2008:12) E isso faz parte de um processo de esvaziamento da autonomia docente.

Como afirmam Bezerra Neto;Bezerra;Jacomelli (2009:39):

Ao contrário das propostas anteriores, que direcionava as ações para a atuação do professor, quando enfatizava ora métodos de ensino, ora as práticas pedagógicas, ora a organização da sala de aula, as formas de avaliação e outras coisas relacionadas ao fazer pedagógico, a atual proposta centra-se na figura do gestor escolar, a quem foi delegado a responsabilidade pela educação, não só por ele ter que administrar a burocracia da escola e 
responder por todos os índices positivos ou negativos do ensino, mas ampliando o seu campo de atuação Ihe atribuindo o papel de formador do formador, ou seja, cabe ao gestor formar o professor que formará o aluno.

Portanto, há uma clareza que o processo de ensino-aprendizagem fica submetido aos números exigidos pelo Banco Mundial e a lógica do mercado.

A Proposta vai além, afirmando que os administradores escolares, como agentes formadores, devem aplicar com os professores tudo aquilo que recomendam a eles e apliquem com os alunos.

Sem dúvida nenhuma uma imposição de ideias que quebra, profundamente, a autonomia do professor como produtor do conhecimento, de um saber novo e de sua autonomia para o desenvolvimento disso, descumprindo o Estatuto do Magistério. E Bezerra Neto;Bezerra;Jacomelli (2009:39) vão além:

Poderíamos supor que ao gestor está sendo dada, finalmente, uma função educativa e pedagógica, distante das visões da administração gerencial tecnocrática e racional, tão comum em nosso cotidiano, mas estamos convictos de que a busca da racionalidade administrativa se amplia cada vez mais com esta proposta fazendo com que o diretor em cada escola, seja visto como um preposto do Estado que vai fiscalizar o trabalho do professor, controlar o uso do material determinado pela Secretaria, controlar a freqüência, ou seja, ele vai gerenciar o trabalho pedagógico da escola no sentido de cobrar a eficiência no uso do recurso didático enviado às escolas, visando atingir fins determinados. Nesse sentido, o gestor, como uma espécie de Fiscal do Governo, passa a controlar o trabalho do professor, e estes passam a controlar seus colegas, estimulados por uma política de gratificações que faz com que o professor se torne responsável pelo trabalho do outro na medida em que a freqüência e o rendimento de uns interferem no salário/bônus dos outros.

\begin{abstract}
Assim o novo currículo é apresentado como uma visão difundida pelo Banco Mundial, através do relatório elaborado por Jacques Delors ${ }^{24}$ em seu texto Educação um tesouro a descobrir, publicado com o apoio da UNESCO, cujos princípios fundamentais desenhados para a educação do século XXI são o de aprender a conhecer, aprender a fazer, aprender a conviver com os outros a aprender a ser.
\end{abstract}

\footnotetext{
${ }^{24}$ Apud Neto; Bezerra;Jacomelli “Currículo Escolar de São Paulo: Uma proposta para Discussão" in Revista Educação e Cidadania, São Paulo, vol. 8, nº 1, p. 38, 2009
} 
Assim sendo, alunos e professores são colocados no mesmo patamar, desconsiderando os conhecimentos adquiridos por estes últimos no processo de formação e pela própria experiência adquirida nos anos de exercício profissional, sendo esta condição discutida e apropriada por alguns construtivistas, de forma equivocada.

Isso gera uma preocupação na organização de todo o processo pedagógico escolar, onde, Bezerra Neto;Bezerra;Jacomelli (2009) afirmam que o risco desse tipo de prerrogativa é o esvaziamento do papel do professor e o questionamento da sua capacidade de trabalho, refletindo outra concepção hegemônica na educação, sugerindo implicitamente que os professores podem se tornar desnecessários no processo de ensino/aprendizagem, pois não caberia mais a ele ensinar, já que o eixo da educação foi deslocado do ensino para a aprendizagem, ou seja, o professor não teria mais o que ensinar; agora, cabe ao aluno aprender a aprender.

A importância dada ao aprender a aprender é justificada pelo argumento de que a sociedade do século XXI "é cada vez mais caracterizada pelo uso intensivo do conhecimento, seja para trabalhar, conviver ou exercer a cidadania, seja para cuidar do ambiente em que se vive." (Proposta,2008:4)

Sendo assim, a SEE coloca o conhecimento tão importante na atualidade, assim como uma educação permanente, onde o ensino superior não será mais um diferencial suficiente no processo de formação, exposto na Proposta (2008:5):

O Brasil caminha rumo à democratização do acesso a níveis educacionais além do ensino obrigatório, e com mais gente estudando, a posse de um diploma de nível superior deixa de ser um diferencial suficiente e características cognitivas e afetivas são cada vez mais valorizadas, como as capacidades de resolver problemas, trabalhar em grupo, continuar aprendendo e agir de modo cooperativo, pertinente em situações complexas.

A justificativa da não necessidade de um diploma superior em detrimento da democracia do acesso a níveis educacionais é um equívoco, se não um absurdo, registrado num documento oficial de tal importância como este. Como isto é defendido se as políticas educacionais dizem outra coisa? 
A questão não é substituir uma formação acadêmica e teórica por uma educação focalizada no ensino e aprendizagem, voltada para o social, para o vivido, para o cotidiano. E sim conjugar as duas, num movimento estrutural-pedagógico que condiza com a realidade da escola e para a escola.

Assim, numa análise mais consistente, Bezerra Neto;Bezerra;Jacomelli (2009) afirmam que há um deslocamento do eixo curricular do ensinar para o aprender, do professor como sujeito do processo para o aluno, como responsável pela aprendizagem, retomando a teoria do capital humano, tão propalada durante a ditadura militar, procurando estimular, individualmente, a autoaprendizagem para se alcançar um suposto desenvolvimento para inserção no mundo de modo produtivo e solidário. Isso tem a ver com a centragem do processo de aprendizagem no indivíduo, na relação de maneira privada e não mais pública, em uma lógica neoliberal.

Outro aspecto da Proposta Curricular é a ênfase na formação para o trabalho, de um modo produtivo, como afirma a Proposta (2008:40): "A relevância e a pertinência das aprendizagens escolares nessas instituições são decisivas para que o acesso a elas proporcione uma oportunidade real de aprendizado para inserção no mundo de modo produtivo e solidário".

Como já dito anteriormente, esses alunos são preparados para um trabalho braçal, com a diminuição do papel e participação do professor na elaboração curricular e em seu trabalho em sala de aula.

Com isso, há um aumento das responsabilidades do aluno em aprender a aprender, visando um enquadramento no capitalismo vigente através da precariedade dos empregos, indispensável a esse sistema, com uma certa naturalização das desigualdades, alimentando a sociedade produtiva capitalista, assim como afirma Sanfelice;Minto;Lombardi (2009:50):

A reforma curricular aparece articulada ao mundo do trabalho, mas trata-se de uma concepção característica da atual etapa do desenvolvimento capitalista: o trabalho flexível e que deve ser adequado a uma produção crescentemente automatizada e fundada na micro-eletrônica e nas tecnologias da informação. Por essa razão, a Proposta defende uma educação flexível que prepare trabalhadores igualmente flexíveis. ${ }^{25}$

\footnotetext{
${ }^{25}$ Isso tem a ver com o toyotismo, o polifuncionalismo e a perspectiva neodarwinista de se adaptar para viver.
} 
Mas a questão, além disso, seria a distorção do conceito de solidariedade, que, segundo Bezerra Neto;Bezerra;Jacomelli (2009) é redesenhado de forma que naturaliza a desigualdade ao propor uma sociedade mais solidária e compreensiva com relação às diferenças em que as pessoas devem se solidarizar umas com as outras, entretanto, essa onda de solidariedade retira das mãos do Estado a responsabilidade pela distribuição da renda e da riqueza produzida, quando sugere que a sociedade deve gerenciar por si mesma os problemas e conflitos sociais.

Isso nos sugere uma lógica implantada na empresa capitalista em que os funcionários doam parte de seu tempo e trabalho em ações solidárias de vários tipos que responde pelo nome de voluntariado. $\mathrm{Na}$ escola aparece com o codinome "amigos da escola" e "educação solidária - adote uma escola".

É inerente que o jovem - os alunos - sejam responsabilizados cada vez mais por seus destinos, segundo essa Proposta (2008:10):

Autonomia para gerenciar a própria aprendizagem (aprender a aprender) e o resultado dela em intervenções solidárias (aprender a fazer e conviver) deve ser à base da educação das crianças, dos jovens e dos adultos, que têm em suas mãos a continuidade da produção cultural e das práticas sociais.

Numa concepção em que o docente não tem o que ensinar, "dado que todo conhecimento deve partir do que o aluno já sabe" Bezerra Neto;Bezerra;Jacomelli. $(2009 ; 41)$, defende-se que o professor não deve se limitar:

A suprir os alunos de saberes, mas é o parceiro de fazeres culturais, aquele que promove de muitas formas o desejo de aprender, sobretudo com o exemplo de seu próprio entusiasmo pela cultura humanista, científica, artística e literária. (PROPOSTA, 2008:8)

Assim, o professor deve ser apenas mediador de ações pedagógicas e culturais, ou seja, ensinar o aluno para um certo gosto pela autoaprendizagem. 
Isso gera uma individualização do processo de aprendizagem na escola, não garantindo a todos os alunos a igualdade no fim da trajetória escolar, pois, nesse sistema, cada um tem uma forma diferente de lidar com seus desejos pessoais.

Como consequência disso, a responsabilidade pelos avanços e fracassos é transferida para os professores. E o sucesso, consequentemente, aparece como sendo da gestão.

Por um lado, tal responsabilidade é consequência de os professores não saberem instigar o gosto pelo aprender; e por outro lado, ao aluno, que não demonstra interesse e nem capacidade de aprender, isentando o sistema educacional de qualquer encargo pela situação caótica do ensino expresso no baixo rendimento dos alunos.

Depois de analisados as características mais estruturais da proposta Curricular do estado de São Paulo, agora é de extrema necessidade uma análise das concepções ligadas as formas e os conteúdos dentro da lógica da aprendizagem proposta.

Com isso, nesse currículo, as competências são tornadas referências para que, segundo Proposta (2009:9):

\begin{abstract}
Tenha o compromisso de articular as disciplinas e as atividades escolares com aquilo que se espera que os alunos aprendam ao longo do ano...Um currículo referido as competências supõe que se aceite o desafio de promover os conhecimentos próprios de cada disciplina articuladamente às competências e habilidades do aluno. É com essas competências e habilidades que ele contará para fazer sua leitura do mundo, para compreendê-lo e propor explicações, para defender suas ideias e compartilhar novas e melhores formas de ser, na complexidade em que hoje isso é requerido. É com elas que, em síntese, ele poderá enfrentar problemas e agir de modo coerente em favor das múltiplas possibilidades de solução e gestão.
\end{abstract}

Nota-se claramente um discurso ligado ao empreendedorismo capitalista, bastante generalizado, falando-se em solução e gestão, termos muito utilizados no mercado.

Machado (2002) levanta que um elemento fundamental para a caracterização da ideia de competência é justamente o âmbito no qual ele exerce. Não existe uma competência sem a referência a um contexto no qual ela se materializa: a competência 
sempre tem um âmbito, o que nos faz considerar bastante natural uma expressão como "Isto não é da minha competência".

Ele vai além - afirma que, quanto mais bem delimitado é o âmbito de referência, mais é caracterizado uma pessoa competente. É mais simples prefigurar um espectro de competências pessoais a serem desenvolvidas em um curso superior, de natureza profissionalizante, do que fazê-lo com relação a alunos da educação básica.

Para caracterizar melhor a solidariedade entre a idéia de competências e de âmbito, uma análise da Matriz de Competências do Exame Nacional do Ensino Médio (MEC/INEP/1998) pode ser elucidativa.

Tendo em vista a composição da referida matriz, professores de todas as disciplinas ou temas do ensino médio reuniram-se e tentaram explicitar o que buscavam desenvolver por meio de suas disciplinas e programas, considerando a formação pessoal de um aluno, ao final da educação básica. De modo sintético, o resultado foi esse:

- capacidade de expressão em diferentes linguagens;

- capacidade de compreensão de fenômenos físicos, naturais e sociais;

- capacidade de referir os conceitos disciplinares a contextos específicos, enfrentando situações-problema;

- capacidade de argumentar, de negociar significados, buscando acordos por meio do discurso;

- capacidade de projetar ações, de pensar propostas de intervenção solidária na realidade.

Segundo Machado (2002), as formas de realização das competências foram chamadas de habilidades. Para desenvolver as habilidades, recorre-se às disciplinas, que são apenas meios para isso. As habilidades funcionam como âncora para referir as competências aos âmbitos nos quais se realizarão as competências, evitando-se o desvio de ancorá-las diretamente nos programas das disciplinas, o que conduz ao risco inerente de transformá-los em fins em si mesmo.

Outra justificativa para a utilização das competências, como afirma Proposta (2007) seria que elas podem ser consideradas em uma perspectiva geral, isto é, no que 
têm em comum com as disciplinas e tarefas escolares, ou então no que têm de específico.

O documento afirma ainda que nessa etapa curricular a tríade sobre a qual competências e habilidades são desenvolvidas pode ser assim caracterizada: a) o adolescente e as características de suas ações e pensamentos; b) o professor, suas características pessoais e profissionais e a qualidade de suas mediações; e c) os conteúdos das disciplinas e as metodologias para seu ensino e aprendizagem.

Assim, temos a crítica de Neto;Bezerra;Jacomelli (2009:42):

\begin{abstract}
Competências e habilidades remetem a um individualismo gritante, pois nem todos são competentes e hábeis para aprender tudo ou qualquer coisa, assim, acaba sendo naturalizada também a não aprendizagem, pois cada um tem um ritmo diferente e a escola não tem como atender a todas as expectativas de todos os alunos, de forma que alguns podem ser excluídos do processo de aprendizagem em razão de suas baixas capacidades. Essa exclusão, entretanto, não se dá na forma de abandono da escola, mas por meio da permanência obrigatória, porém, desprovida de objetividade na transmissão de conteúdos socialmente acumulados fazendo com que os alunos não tenham expectativas com relação à escola, deixando de vislumbrar o seu devido valor na sua formação pessoal e social.
\end{abstract}

Ainda sobre competências e habilidades, Sanfelice;Minto;Lombardi (2009) afirmam que não há nenhuma novidade em relação ao que já vem sendo feito pela Secretaria Estadual de Educação (SEE-SP), onde há um reducionismo do raciocínio. A justificativa para isso é dada por a pedagogia ser tomada como uma única das suas manifestações: a das competências e habilidades. Uma pedagogia pobre, vazia de conhecimentos significativos e que vem sendo estimulada pelas Agências Financiadoras e organismos multilaterais para resolver os problemas de escolaridade no chamado Terceiro Mundo.

Continuam afirmando que a mão de obra barata que os países do Terceiro Mundo têm em abundância, precisa ser preparada, segundo a lógica do mercado, com habilidades e competências para se constituir em classe trabalhadora flexível e disponível à exploração do capital. Contraditoriamente ao discurso, a sociedade do conhecimento não é para todos e nem para muitos. E levantam algumas questões: 
Quem definiu as habilidades e competências desejáveis? Quem definiu os conteúdos da proposta curricular do Estado? Quem definiu as metas a serem alcançadas? Quem, lá nos idos de FHC, usurpou um projeto de LDB construído pela sociedade civil e impôs outro goela abaixo? (Sanfelice;Minto;Lombardi, 2009:54)

Há certamente um equívoco da SEE em promover um currículo voltado para as competências, com uma suposta democratização da escola, alegada pela necessidade de acessibilidade a todos e diversa no tratamento de cada um.

Com a justificativa que é impossível estabelecer o que deve ser ensinado a todos e sem exceção, a Proposta (2009) optou por construir a unidade com ênfase no que é indispensável que todos tenham aprendido ao final do processo, considerando a diversidade. E vai além afirmando que todo tem o direito de construir, ao longo de sua escolaridade, um conjunto básico de competências, definido pela lei. ${ }^{26}$

Segundo a Lei de Diretrizes e Bases - LDB (Lei 9394/96), o foco do ensino foi deslocado para o da aprendizagem, eliminando dessa forma a liberdade de ensino, e incorporando o direito de aprender, como um direito do cidadão, como afirmam Neto;Bezerra;Jacomelli (2009). Cidadão este compreendido como consumidor.

Esses mesmos autores concluem que com isto, o Estado se exime do dever de ensinar e passa para o cidadão o direito de buscar conhecimentos, mesmo que estes não sejam disponibilizados para o trabalhador, caracterizando uma negligência do Estado principalmente aos mais desprovidos de condições materiais e intelectuais.

Como objetivo geral desse esboço metodológico de letramento, é apontado um domínio da língua materna e de outras formas de linguagem, com um repertório cultural de cada indivíduo e de seu grupo social, que a elas dá sentido.

$\mathrm{Na}$ proposta curricular, essa chamada competência de leitura e escrita é supostamente superada para além de suas finalidades, não garantidas na prática por uma falta de formação dos professores para isso, principalmente nas áreas das exatas, assim como outras áreas, incluindo nisso a língua portuguesa.

\footnotetext{
${ }^{26}$ Proposta (2008:41):" Na década de 1990, o Ministério da Educação publicou os Parâmetros Curriculares Nacionais, reforçando a tendência da crítica ao ensino conteudista propondo o ensino por competências."
} 
Essas competências, que seguem orientações do ENEM, são expressas da seguinte forma pela Proposta (2008:14-15) e já corroboradas por Machado (2002):

\begin{abstract}
Construir e aplicar conceitos das várias áreas do conhecimento para a compreensão de fenômenos naturais, de processos histórico-geográficos, da produção tecnológica e das manifestações artísticas;

Dominar a norma culta da Língua Portuguesa e fazer uso das linguagens matemática, artística e científica;

Selecionar, organizar, relacionar, interpretar dados e informações representados de diferentes formas, para tomar decisões e enfrentar situaçõesproblema;

Relacionar informações, representadas em diferentes formas, e conhecimentos disponíveis em situações concretas, para construir argumentação consistente;

Recorrer aos conhecimentos desenvolvidos na escola para elaborar propostas de intervenção solidária na realidade, respeitando os valores humanos e considerando a diversidade sociocultural.
\end{abstract}

Aqui é apresentada uma série de fatores, de uma alta complexidade de análise e implementação prática, principalmente para um tema tão delicado e historicamente alocado num problema nacional e regional, como a leitura e a escrita, com uma formação profissional deteriorada, onde muitas vezes ela não existe ou é feita de uma forma não presencial.

Como já dito, o currículo em estudo foi construído de uma forma não participativa, elevando os gestores a fiscalizadores de sua implementação, colocando o professor como um simples mediador de situações em sala de aula e o repasse da responsabilidade de aprender ao aluno. Assim como afirma Neto;Bezerra;Jacomelli (2009:44):

A Secretaria estadual de Educação, em sua proposta de currículo, desconfigura
o trabalho docente e o conecta a várias 'ferramentas' (manual do professor,
apostila dos alunos e caderno do gestor), que, motivado por uma fala
encantadora de realização de projetos (pedagogia dos projetos), visa
transformar o professor em uma marionete do sistema, e as capacitações que
são oferecidas mais parecem treinamentos que se apresentam substituindo,
formatando e restringindo o significado da palavra didática por modelo.

Com tudo isso, somos obrigados em acreditar na quebra de paradigmas na educação de nosso estado, rompendo com o princípio de que a educação é uma boa 
mercadoria, mesmo quando o conteúdo é de má qualidade. É preciso superar a ótica paupérrima de uma pedagogia das habilidades e competências. É preciso desfocar a avaliação da produtividade para que ela possa ser da aprendizagem de conteúdos, de conhecimentos e de valores significativos e relevantes para toda a vida.

Há de se ter uma reflexão e crítica acerca da instrumentalização do aluno, assim como de todos os atores escolares, no plano teórico e no vivido, para um ensino e aprendizagem voltados para o mínimo necessário para se tornar coadjuvante no sistema capitalista até então vigente.

Como consequência disto, há uma criação de mão-de-obra barata, pseudoespecializada e não garantindo, mesmo no direito de aprender, um caminho que supere a negação do trabalho a partir da cidadania do capital, com ciência de seus direitos e uma formação crítica que contribua realmente com a transformação de nossa sociedade e na construção de um mundo justo para as próximas gerações.

Como proposta de um currículo mais eficaz e justo, Sanfelice;Minto;Lombardi (2009:57) dá a seguinte diretiva:

Ao contrário de uma concepção educacional calcada numa perspectiva neoliberal, privatista e mercadológica, deve-se lutar para que a escola continue a ser o espaço por excelência de socialização de crianças, jovens e adultos, cumprindo um fundamental papel civilizatório e formativo. Não está em questão o uso ou não da informática e dos novos meios de comunicação, pois se trata de uma conquista da humanidade e que deve ser acessível a todos. Deve-se usar de todos os meios e conquistas tecnológicas na educação, pois o que está em jogo é construirmos uma rede educacional que possibilite a todos uma educação de qualidade, com infraestrutura física adequada e na qual haja respeito, preparação e valorização dos trabalhadores e educadores.

Analisado o documento básico da Proposta (2009), há uma necessidade de entender outros documentos inerentes a essa política curricular, relacionando-os para um maior entendimento dessa política pública para a educação, equivocada e colocada como uma mera mercadoria, que atende a interesses da elite posta nesse momento histórico, assim como a lógica do ensino da geografia como recorte proposto nesse trabalho. 


\title{
3.2.1. Reorientação curricular dos ensinos Fundamental e Médio - Grade Curricular
}

Seguindo a política de implementação do novo currículo, a SEE-SP, através de seu departamento jurídico, divulga a Resolução SE-92, de 19/12/2007, que estabelece diretrizes para organização curricular do ensino fundamental e médio das escolas estaduais.

Essa resolução, já no final do ano de 2007, dá-se um início para a consolidação de um novo currículo, até então desconhecido no cotidiano da rede, priorizando no cerne de todo ensino estadual, a organização e o funcionamento do ensino básico.

Como justificativa dessa resolução, a SEE considera:

\begin{abstract}
A reorganização curricular da educação básica como uma das ações viabilizadoras das metas de melhoria do processo educacional paulista;

A implementação, em 2008, das propostas curriculares de ensino fundamental e médio organizadas por esta Pasta;

A necessidade de se estabelecer diretrizes que orientem as unidades escolares na montagem das matrizes curriculares desses níveis de ensino.(SEE$\mathrm{SP}, 2007)^{27}$
\end{abstract}

Para se ter uma reorganização curricular, com ações viabilizadoras de metas de melhoria educacional, a SEE privilegia o aumento da carga horária, ou seja, os dias letivos anuais. É como expressa o Art. $1^{\circ}$ da atual resolução:

A organização curricular das escolas estaduais que oferecem ensino fundamental e médio se desenvolverá em 200(duzentos dias) letivos, com a carga horária anual estabelecida pela presente resolução. ${ }^{28}$

Antes fadada aos 180 dias letivos, há um certo consenso quanto ao aumento da carga horária letiva escolar. Mas é importante saber que, mesmo com o aumento dos dias de atividades escolares, é muito cedo afirmar que isso refletirá na qualidade do

\footnotetext{
${ }^{27}$ São Paulo. Resolução SE-92, de 19/12/2007. Secretaria da Educação (SEE). São Paulo, 2007.

${ }^{28}$ Ibidem.
} 
ensino e da educação em geral. A justificativa principal é simplesmente uma adequação a LDB vigente.

Sem ações que privilegiem a qualidade de ensino nas escolas, existe uma ineficiência no aumento da carga horária, precarizando ainda mais as escolas. Então, o chamado ensino fundamental, foi definido da seguinte maneira, como consta nos artigos seqüentes da resolução:

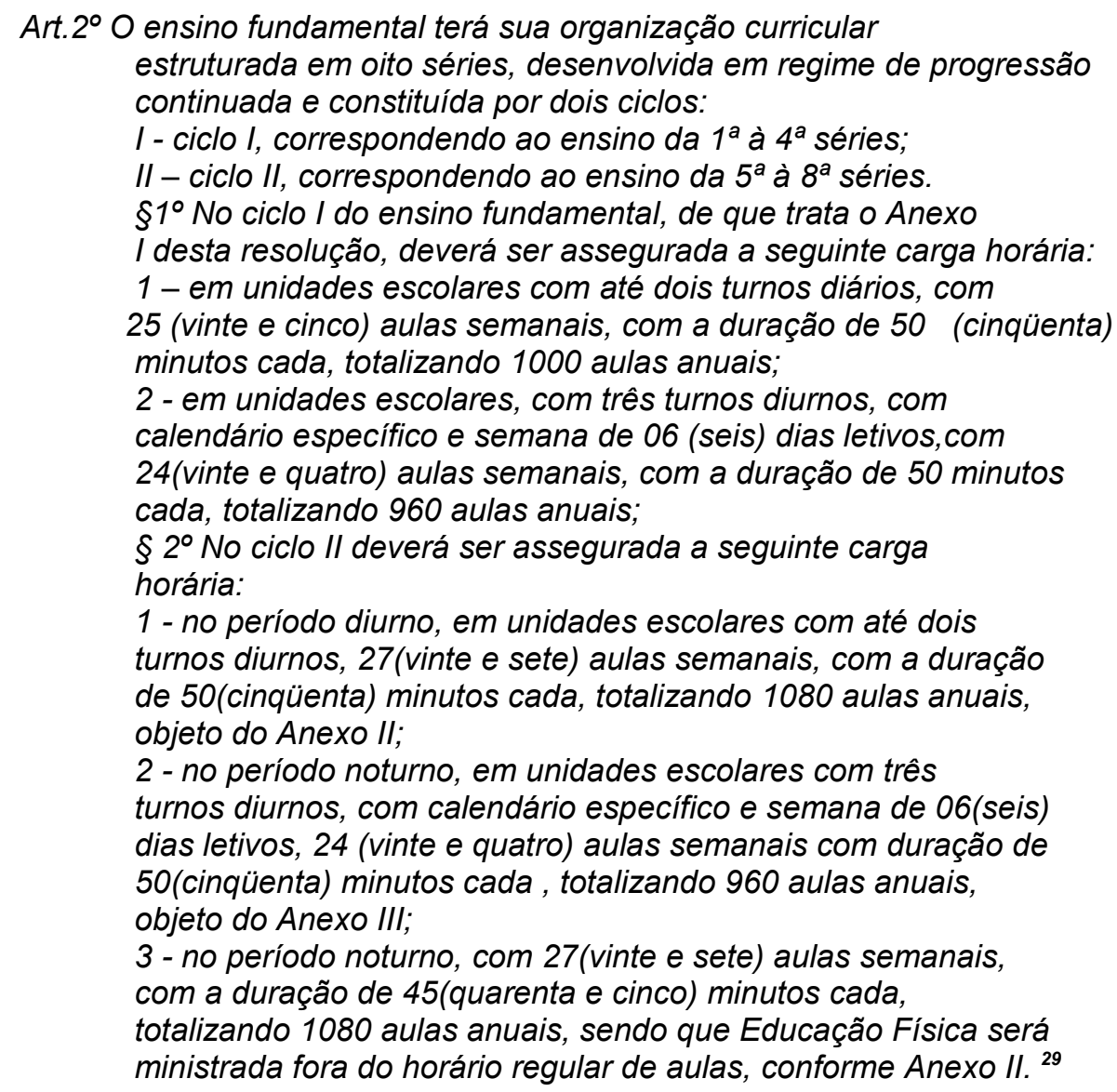

Há uma clara valorização da carga horária diurna, inclusive com a institucionalização definitiva do chamado "turno da fome" ${ }^{30}$ dentro da carga tripla do diurno. As aulas no período noturno são com uma carga mais reduzida, não

\footnotetext{
${ }^{29}$ Ibidem, pg 17.

${ }^{30}$ Turno da fome entendido como o período das $10 \mathrm{~h} 00$ as $14 \mathrm{~h} 00$.
} 
prevalecendo aqui o fator qualidade na quantidade de aulas, levantando uma situação mais peculiar por se tratar de alunos trabalhadores em sua maioria.

A progressão continuada é aplicada em todas as séries, com a Deliberação CEE 9/97, que instituiu o regime de progressão continuada no ensino fundamental, com a possibilidade de ser organizado, no Sistema de Ensino do Estado de São Paulo, em um ou mais ciclos.

O regime de progressão continuada pede avaliação continuada também do processo de aprendizagem dos alunos, devendo ser objeto de recuperação continuada e paralela, a partir de resultados periódicos parciais e, se necessário, no final de cada período letivo.

A escola organizada em mais de um ciclo deve garantir também a progressão continuada na transição de um para outro ciclo.

Enfatiza essa Deliberação, à exaustão, a necessidade de avaliações da aprendizagem, do desenvolvimento do aluno, do próprio ensino e avaliações institucionais; a necessidade das atividades de reforço e de recuperação (paralelas e contínuas), de meios alternativos de adaptação, reclassificação, avanço, reconhecimento, aproveitamento e aceleração de estudos, de indicadores de desempenho, controle de freqüência dos alunos e dos dispositivos regimentais adequados.

Em outras palavras, todo esforço possível e todos os recursos disponíveis devem ser providos pela escola e pelo sistema para levar o aluno ao aproveitamento das atividades escolares para seu desenvolvimento cognitivo e social e, por conseqüência, ao progresso, o que afasta a concepção de progressão continuada da idéia de promoção automática, sugestiva de menor investimento no ensino, reforço, avaliação, reavaliação.

E isso é estratégia intencionalizada para quê, a progressão continuada, como teoria e prática pedagógica, se torne promoção automática, como teoria e prática do capital, a serviço dos dados estatísticos educacionais, legitimando assim os ideários neoliberais. 
Mas infelizmente, ante a ineficiência do sistema de ensino em administrar as realidades pedagógicas e funcionais das unidades escolares, ela foi transformada em promoção automática, negligenciando as ambições dos alunos frente aos seus aprendizados e realidades específicas de vida dentro de sua escola.

Considerando que a proposta curricular do estado de São Paulo é nova, o estudo encontra algumas dificuldades de relacionar o que foi implementado e o que realmente será, mas evidenciando que há necessidades de mudanças.

São muitas escolas, com uma heterogeneidade enorme, num currículo único e demandas extensas, com falta de recursos humanos e estrutura física para uma melhor qualidade do ensino e aprendizagem dos alunos.

A Proposta Curricular foi apresentada a comunidade escolar de uma maneira não democrática, expondo a fragilidade da escola em criticar e lutar para ter um espaço de opinião e implementação. Mas o aparelho do Estado projeta na proposta e conta com a burocracia humana para implementá-la, dentro de uma lógica centralizadadescentralizada de implementação de políticas públicas para a educação. É isso que veremos a seguir.

\subsubsection{Concepções organizacionais de implementação curricular}

Depois de consolidadas as bases legais de implementação de um novo currículo, a SEE organiza um encontro de Dirigentes de Ensino, Supervisores de Ensino e Diretores de Escola, entre os dias 23 e 24 de janeiro de 2008.

Esses profissionais são vinculados a Coordenadoria da Grande São Paulo (COGSP), através de várias Diretorias de Ensino distribuídas nas diversas cidades que compõem a região metropolitana de São Paulo.

Essa reunião, de fundamental importância para uma implementação e consolidação de um novo currículo, no entendimento da própria SEE, foi pautada 
essencialmente num documento organizacional que foi chamado de "Planejamento 2008 - Apresentação dos Principais Projetos e Ações".

Esse documento foi posteriormente disponibilizado aos diretores e professores da unidades escolares, através do sítio http://www.sãopaulofazescola.sp.gov.br .

Inclusive, este endereço eletrônico foi criado para orientar, administrar e deixar público todos os documentos, textos e a própria fundamentação teórica e prática, inerentes ao acompanhamento de implantação do novo currículo nas unidades escolares. É nesse sítio que tivemos acesso a essas informações para um esclarecimento mais extenso do problema.

Segundo o documento, a pauta dos dois dias estava dividida entre as discussões relativas a proposta curricular, tais como recuperação paralela e intensiva, diversificação do currículo do ensino médio, avaliação e o EJA (Educação de Jovens e Adultos), e a apresentação oficial do plano de dez metas da educação paulista na gestão do ex-governador José Serra.

Uma pauta bastante "enxuta" mas, tendo uma reflexão mais aprofundada, os principais pontos de interesse até então estavam contemplados nessa reunião, ou seja, na nova proposta curricular.

Umas das primeiras premissas de viabilidade do novo currículo seria uma pesquisa direcionada nas condições atuais das unidades escolares.

Foi contratada uma empresa de pesquisa, a Fundação Instituto de Pesquisas Econômicas (FIPE) para verificação das condições existentes nas unidades escolares do estado, assim como subsidiária para um maior aprimoramento da qualidade do banco de dados de informações escolares.

O cronograma de pesquisa foi de dezembro de 2007 até abril de 2008, onde, tais dados até então confidenciais, pois nada sobre os resultados foram publicados. A metodologia de pesquisa estaria direcionada em entrevistas via e-mail, aos diretores de escola, assim como as visitas de pesquisadores da FIPE para verificação física de instalações, recursos existentes e funcionamento das escolas, além de entrevistas presenciais. 
A segunda premissa de viabilidade estava direcionada a implementação do novo currículo em si, onde a estrutura da proposta estaria ligada aos princípios da organização curricular, que foi descrita no documento da reunião da seguinte forma:

\author{
Currículo é cultura; ${ }^{31}$ \\ Currículo referido a competências; \\ Currículo que tem como prioridade à competência \\ leitora e escritora; \\ Currículo que articula as competências para \\ aprender; \\ Currículo contextualizado no mundo do trabalho. ${ }^{32}$
}

As características do processo de construção da proposta estão pautadas no respeito aos saberes já construídos, e nas orientações para a gestão do currículo na escola e da aprendizagem em sala de aula.

Como documentos de subsídio à proposta, foram lançados cadernos teóricos e procedimentais divididos pelas áreas do conhecimento, explicitando as bases fundamentais, inclusive de geografia, para um melhor entendimento dos princípios e conceitos do novo currículo junto aos professores e gestores. Esses cadernos, além de serem uma orientação voltada aos professores, centralizam conceitos e procedimentos das áreas, "engessando" ainda mais as decisões em cada unidade escolar. Eles foram chamados de documentos 1,2 e 3 , sendo eles:

- Documento 1: chamados de base, são os cadernos com as propostas curriculares divididos pelas áreas do conhecimento;

- Documento 2: são os cadernos de orientações aos gestores;

- Documento 3: são os cadernos de orientações aos professores. ${ }^{33}$

Os cadernos dos gestores foram publicados para que, gradativamente, por bimestre, apresentem "sugestões de organização do trabalho dos especialistas

\footnotetext{
${ }^{31}$ Segundo Silva (2007) os estudos culturais para a análise do currículo e para o currículo permitem-nos conceber o currículo como campo de luta em torno da significação e da identidade. A partir dos estudos culturais podemos ver o conhecimento e o currículo como campos culturais, como campos sujeitos à disputa e à interpretação e à interpretação, nos quais os diferentes grupos tentam estabelecer sua hegemonia. Nessa perspectiva, o currículo é um artefato cultural empelo menos dosi sentidos: 1) a "instituição" do currículo é uma invenção social como qualquer outra; 2) o conteúdo do currículo é uma construção social.

${ }^{32}$ São Paulo. Encontro de Dirigentes Regionais, Supervisores de Ensino e Diretores de Escolas - COGSP: Planejamento 2008 - Apresentação dos Principais Projetos e Ações. Secretaria da Educação (SEE). São Paulo, 2007.

${ }^{33}$ Posteriormente são publicados os cadernos de alunos, que serão explicitados posteriormente.
} 
responsáveis pela gestão do currículo na escola, além de propostas de agenda, cronograma, atividades e organização de recursos para apoiar o trabalho do diretor, do professor coordenador, dos ATPs e do supervisor." ${ }^{34}$

Aparecem como manuais de como se deve trabalhar com a nova proposta curricular, pois, sem a participação efetiva dos professores na construção da proposta, os gestores ficaram encarregados de encaminhar e executar, num primeiro momento, e fiscalizar, posteriormente, o novo currículo, como já dito. E isso é central, visto a condição de coadjuvante que os professores são colocados nessa proposta.

Os cadernos dos professores aparecem também como manuais de trabalho, divididos em todas as áreas do conhecimento, tanto dos ensinos fundamentais I e II, além do ensino médio. Esses cadernos propõem atividades docentes para todas as aulas, organizadas por bimestre, com:

Indicação clara das competências e habilidades a serem desenvolvidas pelos alunos, em cada tema ou tópico dos conteúdos;

Sugestões de aulas;

Sugestões de materiais complementares;

Propostas de avaliações;

Projetos de Recuperação Paralela. ${ }^{35}$

Os cadernos (que chamaremos no decorrer da pesquisa de cartilhas), esvaziam a autonomia docente e buscam uniformizar o processo; negando, em último caso, a proposta de aprender a partir de experiências dos estudantes.

Além desses cadernos, vários outros tipos de materiais foram selecionados para o apoio docente, como produtos multimídia, um sítio interativo e informativo (São Paulo Faz Escola), um aplicativo para registro de experiências de gestão do currículo (de sala de aula e de escola), além de ferramentas de trabalho entre as equipes e de pesquisa junto à rede.

\footnotetext{
${ }^{34}$ Ibidem, pg 25.

${ }^{35}$ Ibidem, pg 25.
} 
O importante salientar que só a disponibilidade dos materiais não implementam um currículo e sim o trabalho humano, colaborativo, freqüente e equalizador de todas as partes envolvidas no processo educacional.

Na seqüência do documento em questão, a SEE propõe diversas ações para um bom andamento da implementação do novo currículo. As ações foram divididas em quatro, lançando ideias básicas e direcionadoras para o trabalho tanto dos gestores como dos professores.

A primeira ação estava baseada numa consulta virtual sobre as boas práticas de ensino e gestão nas escolas. Esta seria feita através do sítio São Paulo faz escola, com previsão de resultados entre 16 de outubro e 3 de dezembro de 2007. Havia uma previsão de divulgação dos resultados, mas até agora não divulgados.

Numa segunda ação, estava a própria divulgação da proposta curricular, com a disponibilização da sugestão de conteúdos programáticos por série e disciplina, com apresentação de videoconferências voltadas aos gestores, supervisores, ATPs, dirigentes de ensino e professores, feitas em dias diferentes, isolando os vários atores sociais das escolas e da rede como um todo. Importante destacar aqui o uso de novas tecnologias, inclusive com o uso recorrente de formação à distância dos professores.

Após essas apresentações, a proposta foi levada pra apreciação do Conselho Estadual de Educação (CEE-SP).

A terceira etapa de ações estava direcionada ao apoio em si à implantação do currículo. Com isso, dois projetos de pasta da SEE foram alocados para essas ações, como a Teia do saber ${ }^{36}$ e a Rede do Saber $^{37}$, com o apoio da Fundação Vanzolini e da CENP, com o objetivo de:

\footnotetext{
${ }^{36}$ Projeto de formação continuada vinculado a CENP-SP (Coordenadoria de Estudos e Normas Pedagógicas), ligado a SEE-SP.

37، A Rede do Saber originou-se da necessidade de oferecer formação em nível superior para cerca de 7.000 professores efetivos da $1^{\mathrm{a}}$ à $4^{\mathrm{a}}$ série da rede pública estadual de ensino, atendendo ao disposto pela Lei de Diretrizes e Bases (LDB). Para atender a esse contingente de profissionais espalhados por todo o Estado, oferecendo uma formação de qualidade e garantindo homogeneidade nas ações desenvolvidas, a SEE-SP investiu em recursos de videoconferência, teleconferência, ferramentas de gestão e ambientes colaborativos na internet, dando aos participantes a oportunidade de aproximar-se dos especialistas de universidades que estão entre as melhores de São Paulo e do país (USP, PUC-SP e Unesp). O Programa PEC - Formação Universitária, desenvolvido entre os anos de 2001 e 2002, foi acompanhado por agência externa e obteve excelente avaliação, tanto do ponto de vista da qualidade da formação quanto da utilização dos recursos investidos. Isso justificou a ampliação da infraestrutura criada para atendê-lo, estendendo-a a todos os profissionais que compõem os quadros da SEE-SP. Dessa forma, em maio de 2003 foi inaugurada a Rede do Saber “ (http://www.rededosaber.sp.gov.br)
} 
Definir programas de formação continuada para supervisores, diretores, professores coordenadores e professores de todas as disciplinas, inclusive professores de EJA;

Nível: especialização lato-sensu (360 horas);

Modalidade: ensino a distância;

Operacionalização: contratação descentralizada de instituições de instituições de ensino superior, já credenciadas para EAD."38

Atualmente, ações como essa, de formação de recursos humanos, da forma que está sendo explanada, não acontecem de uma forma geral.

Mas, nos dias de hoje, foi formada a Escola de Formação, vinculada a SEE e com parcerias da USP, UNESP (Universidade Estadual Paulista) e UNICAMP, sendo chamada de REDEFOR. Sendo um sistema de capacitação e especialização escolar em ambientes virtuais, o estado onera seus custos com formação e divide isolando os professores nos diálogos e reflexões acerca da realidade tanto curricular como cotidiana da escola.

Sem o intuito de ser presencial, o curso é voltado para professores, supervisores, diretores e coordenadores pedagógicos. Esse curso, além de estar voltado para funcionários em exercício, contempla também aqueles que estão ingressando na rede estadual, sendo obrigatório fazê-lo.

A ideia é que este seja uma ação da Rede do Saber, onde esta, como proposta, já foi interessante, mas como ação efetiva, apresenta-se como um factóide.

Finalmente a quarta ação estaria vinculada a um acompanhamento mais presencial da implementação da proposta, monitorando e implementando o enriquecimento desta, através de pesquisa de recursos bibliográficos e tecnológicos, assim como promover a elaboração de cadernos de atividades para os alunos. É importante salientar que essas ações são de implementação inicial da proposta e deveriam acontecer, não somente uma vez, mas de forma contínua na implementação e no próprio currículo.

Ainda pensando em estratégias de orientação de implantação curricular, o documento segue explanando, logo em seguida, na chamada diversificação do ensino médio.

\footnotetext{
${ }^{38}$ Ibidem, pg 25.
} 
O intuito é relacionar esse ciclo com o ensino profissionalizante, estabelecendo uma relação público-privada, lançando uma formação profissionalizante e um apoio na continuidade dos estudos, em parceria com o Centro Estadual de Educação Tecnológica Paula Souza, Fundação Indaiatubana de Educação e Cultura e Fundação Roberto Marinho, tendo apoio da FDE (Fundação para o desenvolvimento da educação) e da CENP, com os seguintes procedimentos:

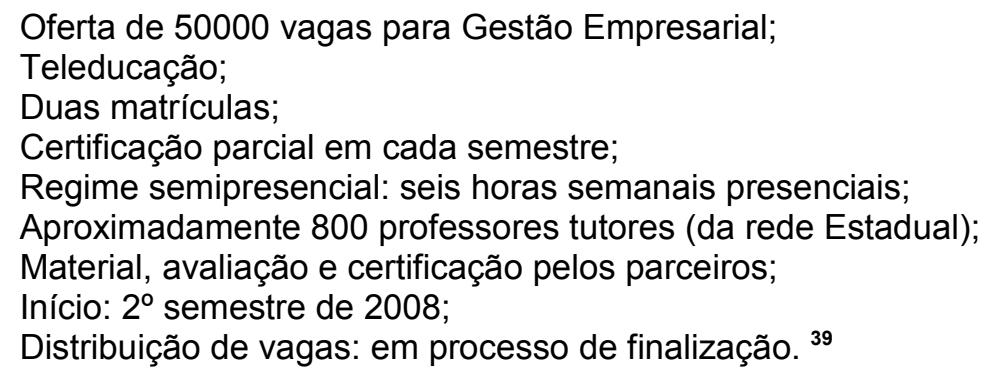

Como destaque, observemos a oferta de 5000 vagas para gestão empresarial, trazendo a tona, e com clareza, uma literal transferência da lógica da escola privada para a escola pública. Com isso, fica claro o processo de esvaziamento da profissão do professor, agora chamado de tutor, quando já foi tratado como mediador, capacitador, etc

Isso, efetivamente, arriscando em afirmar, não ocorre e não ocorreu em nenhum momento. A estrutura administrativa da rede estadual tem dificuldade em gerir suas próprias demandas no ensino normal, e, conseqüentemente, a proposta não saiu do papel.

Ao invés da integração, começaram a criar ETECs (Escola Técnica Estadual Centro Paula Souza) nas escolas estaduais de uma forma precária, seja na infraestrutura de ensino quanto na contratação de especialistas e professores, com um vestibulinho aberto a todos, contrariando a proposta de integração Ensino Médio-Ensino Profissionalizante, correndo o risco de excluir os alunos já matriculados nas próprias unidades escolares onde estão sendo implantadas as novas ETECs.

\footnotetext{
${ }^{39}$ Ibidem, pg 25.
} 
Como apoio à continuidade dos estudos, para aqueles que não tiveram oportunidades de seguir um ensino profissionalizante, o documento explicita ações de apoio como DVDs e materiais de alunos, com revisão de conteúdos e seis horas/aula semanais com conteúdos paralelos ao currículo da $3^{\circ}$ série do ensino médio, com ênfase nas atualidades das disciplinas e na vida contemporânea.

Isso efetivamente já ocorre de uma forma bastante localizada, pois os materiais de alunos nunca existiram ou foram insuficientes para todos.

Os professores são das escolas que ministram tais aulas, sendo, muitas vezes, um complemento de suas aulas já previstas no currículo.

Finalmente, a mais polêmica de todas as ações até aqui explanadas foi à recuperação paralela ${ }^{40}$.

Para criar e executar tal proposta, a equipe da proposta curricular (assim chamado os parceiros CENP, FDE e Fundação Vanzolini), juntamente com uma ONG que trabalha com escola pública, o CENPEC Centro de Estudos e Pesquisas em Educação, Cultura e Ação Comunitária), produziram materiais para serem ministrados nos primeiros 42 dias do ano letivo de 2008 , com o intuito de recuperar um atraso de aprendizagem cumulativo de mais de 10 anos. Uma estratégia de recuperação no mínimo discutível, pois ela se dá por fora da escola.

Isso não foi assumido, mas essa foi à realidade, pois o currículo até então vigente na rede estadual vem de 1994, com a secretária de até então Rose Neubauer ${ }^{41}$, se dissolveu com o tempo (ou mesmo nem foi implementado), muito por ser uma proposta que tende a se estagnar, não tendo participação efetiva dos professores durante os anos letivos, que, nesse caso, com essa proposta curricular atual, há uma chance bastante grande de se repetir.

Como afirma Saviani (2009:35):

Vale refletir, ainda, sobre questões de seleção dos conteúdos e de organização do trabalho pedagógico, constantes de documentos anteriores e reiteradas na proposta atual:

\footnotetext{
${ }^{40}$ Pensada para ser contínua durante todo o ano letivo, a recuperação paralela foi nada mais que um diagnóstico muito precário da situação de aprendizagem dos alunos, através de um jornal distribuído as pressas às escolas e, definitivamente, com resultados e análises muito mal elaborados. 41
} 
A relação entre trinômio identidade-diversidade-autonomia e o binômio interdisciplinaridade-contextualização como capaz de operar a superação dos problemas e contradições da educação básica;

A tradução dos conteúdos em competências e habilidades para dar conta da organização curricular por áreas 'e suas tecnologias' como elemento aglutinador de disciplinas afins e meio para romper com a linearidade e a fragmentação no tratamento dos conceitos, princípios, teorias;

A relação entre o modelo de competências e as práticas de avaliação externa; A associação do modelo de competências à organização por áreas - em que as ciências são acompanhadas pelas respectivas tecnologias: visão da tecnologia dos resultados da produção científica aos fatos (e artefatos) cotidianos da vida contemporânea e não como técnica fundada na ciência.

Essa recuperação paralela na proposta curricular aconteceu de uma forma intensiva, na mesma grade de horários e com os mesmo professores de cada série, com uma estrutura conceitual baseada em estruturas lingüísticas e lógico-matemática, em todas as áreas do conhecimento. Como material de apoio, foram apresentadas atividades conceituais em formato de jornal, divididas por áreas e para todas as séries do ensino fundamental II e ensino médio.

Juntamente com estas, novamente é oferecida a revista do professor, em formato de manual, explicitando passo a passo como deve ser uma aula, em virtude de algum conhecimento e estratégia para isso. Novamente são padronizadas as estratégias e aprendizagens para todo o estado, negligenciando suas especificidades e interesses culturais e regionais dos alunos e escolas em geral.

Para além das questões regionais, é essencial questionar o por que os estudantes não deveriam aprender coisas comuns a todo mundo. E, ao respeitar a experiência dos estudantes, não se está a trabalhar com o local?

Além dessas revistas, foi disponibilizado e explicitado em videoconferências um DVD de orientações para os professores em relação a essa recuperação, dividido por áreas do conhecimento. Uma capacitação de dois professores de matemática e português foi também previsto, mas sem ter um objetivo claro no documento aqui analisado.

Com isso, presume-se que há uma supervalorização do conhecimento matemático e linguístico, como teoria, sendo, de início, as áreas avaliadas pelo SARESP, o qual será tratado posteriormente. 
Com essa recuperação, feita as pressas, e com um intuito claro de demonstrar trabalho e interesse da SEE, os professores vão se manifestando a favor e contra essas ações, pois, de uma certa forma, isso fere a autonomia do professor em ministrar seus conteúdos de aula, assim como sua didática e avaliação no processo de aprendizagem e ensino nas escolas paulistas.

Por outro lado lança a mística de um formato semelhante às escolas particulares, com materiais, assistência pedagógica mais presente e uma ideia teórica de mudança na realidade das escolas.

É importante salientar que, essa proposta curricular, da forma que está sendo implementada, é exclusiva dos alunos do chamado ensino regular, não contemplando a educação de jovens e adultos (EJA), que, a cada ano, é de aparente vontade dos estados, a federalização dessa modalidade de ensino.

Para a avaliação de toda essa implementação curricular, foi lançado o SARESP (Sistema de Avaliação do rendimento Escolar do estado de São Paulo).

Baseado nas avaliações efetuadas pelo governo federal, como o SAEB (Sistema de Avaliação do Ensino Básico), o SARESP é instituído a partir de 1996, para de início, avaliar algumas séries nas disciplinas matemática e português. Como essa avaliação vai ser analisada num subitem específico, nos pautemos apenas a resumir as mudanças ocorridas em tal avaliação para o período de 2008 , até os dias atuais, explicitadas no documento.

Principais mudanças implementadas:

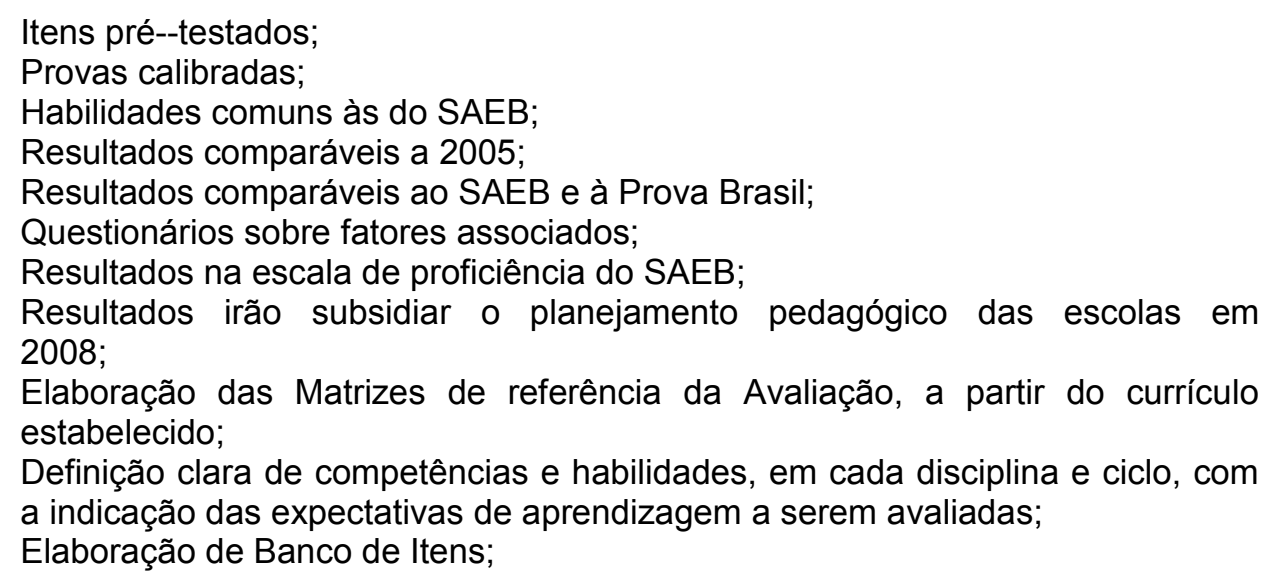


Anualmente, avaliação em Língua Portuguesa e Matemática para compor a gestão dos resultados;

Anualmente, alternância entre disciplinas das áreas de Ciências da Natureza e Ciências Humanas, concomitante à avaliação em Língua Portuguesa e Matemática;

Anualmente, avaliação nas $2^{\mathrm{a}}, 4^{\mathrm{a}}, 6^{\mathrm{a}}$ e $8^{\mathrm{a}}$ séries e na $3^{\mathrm{a}}$ série do $\mathrm{EM}$;

Aplicadores externos à escola (correção cega), exceto para as $1^{\mathrm{a}}$ e $2^{\mathrm{a}}$ série do Ensino Fundamental I, em que o aplicador é professor da escola, mas não da classe avaliada;

Matriz da $2^{\mathrm{a}}$ série do Ensino Médio referida a matriz do ENEM;

ENEM obrigatório aos alunos da $3^{a}$ série do EM..$^{42}$

Muito há de se fazer em relação às avaliações escolares como um todo.É importante considerar que a avaliação dos ciclos é de fundamental importância para uma maior compreensão dos aprendizados e do desenvolvimento dos alunos, mas não avalia, pelo menos de uma forma direta, o desempenho de uma escola, com suas diversas finalidades e os recursos humanos ali alocados.

O problema posto é como a avaliação tem sido utilizada para regular, de forma mercantil, a atividade da escola pública e se desdobrado a partir de políticas pedagógicas e políticas salariais.

Ao fim do documento, aparece toda organização teórica, com seus objetivos, da política educacional do mandato do ex-governador de estado Alberto Goldman, "tampão" de José Serra.

Proposta audaciosa para uma política que percorre mais de 12 anos em busca de uma maior qualidade e profissionalização das escolas estaduais, ela já foi melhor contextualizada num capítulo específico, relacionando, de certa forma, as reformas neoliberais instituídas na educação brasileira e paulista.

A partir do plano de dez metas, formuladas entre 2007-2008, o governo do estado de São Paulo realmente lança um desafio bastante ambicioso para a melhoria da qualidade da educação. De difícil estudo e comprovação dessa metas, devido à complexidade da rede como um todo, a análise desse trabalho é pautada numa crítica a essa proposta, que trás um modelo importado, voltado para as necessidades do capitalismo vigente, assim como afirma Neto;Bezerra;Jacomelli (2009:43):

\footnotetext{
${ }^{42}$ Ibidem, pg. 25
} 
Este tipo de proposta poderia até ser considerada como avanço em relação ao que dispomos, caso não fosse ela uma proposta liberal, própria de uma vertente capitalista, copiada de um modelo importado, que chegou aqui depois das reformas realizadas na Espanha, patrocinadas pela monarquia que governa aquele país e apoiada em um currículo recheado de ideologias conservadoras, montada sob a égide de um modelo empresarial de qualidade total, que tem em seu bojo a proposta de premiar o mérito daqueles que mais se aproximarem dos objetivos dos governantes, ou por que não, os que forem mais subservientes aos interesses do capital nacional e internacional.

Isso mostra como o projeto neoliberal e neoconservador é importado de países como o caso da Espanha.

Numa implementação antidemocrática, a gestão do currículo em sua prática cotidiana é exposto assim pela SEE, como expectativas:

monitoramento permanente das ações; integração da equipe e articulação interna; foco nos resultados e eficiência do processo de gestão; antecipação de problemas e racionalização das soluções; comunicação interna e externa. ${ }^{43}$

Através dessas expectativas, a SEE espera que o desenvolvimento curricular se torne participativo, com uma gestão informacional eficiente, e uma conseqüente integração das equipes. A avaliação de todo processo seria o SARESP, que avalia diretamente os alunos, de algumas séries e algumas disciplinas.

Queremos com essa pesquisa indicar que existe uma limitação avaliativa do processo curricular apenas com esse instrumento, não mostrando as reais facetas da organização dessa nova proposta curricular nas escolas, onde tal avaliação é parte fundamental do currículo.

\subsubsection{Matrizes de Referência de Avaliação Educacional - Documento Básico - SARESP}

\footnotetext{
${ }^{43}$ Ibidem pg. 25 .
} 
A partir de 2007, com a institucionalização e regulamentação da nova proposta curricular, juntamente com uma imposição administrativa, principalmente junto aos gestores da rede de uma forma geral, intermediando os professores e outros atores escolares, a SEE começa, a partir de 2009, uma adequação da avaliação externa a escola vigente até então - o chamado SARESP - ao novo currículo em implantação na rede estadual.

Segundo esse documento ${ }^{44}$, a justificativa para tal ação é a ampla participação dos professores na atual construção curricular ${ }^{45}$, simplificando o currículo e as ações já propostas, e possivelmente não executadas.

O SARESP (Sistema de Avaliação do Rendimento Escolar do Estado de São Paulo) foi criado em 1996 com a intenção de realizar uma avaliação da qualidade de ensino, por meio do rendimento dos alunos, associada ao rendimento da escola. Vale destacar que tal qualidade é estabelecida a partir de uma objetividade quantitativa, gerando uma incoerência nos resultados apresentados.

É válida uma avaliação de toda estrutura de ensino a partir do aprendizado dos alunos, mas muitas questões transversais a isso deixam de ser analisadas, como: as condições sociais, econômicas e espaciais dos alunos refletem nos seus conhecimentos pré-adquiridos? Se em caso positivo, isso reflete no aprendizado do aluno? Uma escola estruturada fisicamente reflete na qualidade de ensino? Como? Numa classe de alunos com dificuldades de aprendizado, a responsabilidade é de quem? Com desempenho insatisfatório em tal avaliação, os professores e gestores foram incompetentes, mesmo como uma estrutura física satisfatória?

Enfim, muitas questões ficam em aberto, se for considerado apenas, na busca de uma maior qualidade de ensino, um conteúdo aprendido apenas no saber científico, ou mesmo somente o vivido, relacionando fracassos escolares a uma prova feita uma vez por ano, externa a escola e sem considerações regionais e culturais da realidade educativa.

\footnotetext{
${ }^{44}$ São Paulo. "Matrizes de Referência para a Avaliação, Documento Básico, SARESP, Ensino Fundamental e Médio", Secretaria de Educação, São Paulo, 2009.

${ }^{45}$ Para a SEE, o que é considerada "ampla participação dos professores" se resume e se simplifica a utilização dos cadernos de alunos nas aulas cotidianas. Ibidem.
} 
O questionamento vai nessa direção onde, uma avaliação como esta é supervalorizada, decidindo os rumos tanto dos alunos como todo funcionalismo e funcionalidade da escola. Assim como afirma Sarno;Cancelliero (2009:14):

O sistema de avaliação externa funciona na lógica da exclusão: o resultado do desempenho dos alunos no Sistema de Avaliação do rendimento Escolar do estado de São Paulo (SARESP) é um dos critérios para o estabelecimento do Índice de Desenvolvimento da Educação do Estado de São Paulo (IDESP), que estipula ano a ano as metas a serem alcançadas pelas escolas estaduais. Quando a instituição não alcança a meta determinada, os profissionais da educação que lá atuam não recebem bônus.

O processo de meritocracia, que leva a política de bônus transparece como aspecto claro da transformação da escola pública em escola empresa. Tal bonificação dos professores é uma espécie de participação nos lucros - a qualidade do que se aprende é reduzida a medidas numéricas e cálculos estatísticos. Sendo assim, o processo avaliativo leva a um processo de financeirização do trabalho docente e do processo de ensino e aprendizagem.

Essa avaliação estadual "utiliza procedimentos metodológicos formais e científicos para coletar e sistematizar dados e produzir informações sobre o desempenho dos alunos ao término das segundas, quartas, sextas e oitavas séries do ensino fundamental, bem como a terceira série do ensino médio." ${ }^{46}$

A questão é que essa avaliação, no caso de ocorrer erros, ou mesmo o planejamento de uma dada escola for direcionado para um aprendizado voltado para esta direção, os profissionais ligados a educação são penalizados, onde a escola, não atingindo o índice pretendido (cada meta é definida a cada ano), é estigmatizada como "ruim", e os responsabilizados por isso são, na maioria das vezes, os professores ${ }^{47}$. Essa é a qualidade do mercado - é como que a escola ganhasse uma etiqueta e um selo de controle da produção.

\footnotetext{
${ }^{46}$ Ibidem.

${ }^{47}$ Sarno;Cancelliero (2009:14): "Essa política de 'crime e castigo' é danosa porque não atenta para algumas premissas básicas: ao se avaliar a escola é preciso considerar seu projeto político-pedagógico e também as desigualdades socioeconômicas. É preciso que se considere efetivamente a estrutura e o funcionamento das unidades escolares e, por consequência, as condições que elas colocam à disposição dos profissionais que lá atuam ou aos estudantes."
} 
A partir de 2007, muitas mudanças foram introduzidas em tal avaliação, adequando-a tecnicamente para um sistema em larga escala, permitindo fazer um acompanhamento dos resultados da rede estadual ao longo dos anos.

Uma dessas mudanças foi uma maior adequação das habilidades propostas no SARESP com as avaliações federais como o SAEB e a Prova Brasil. Na prática são várias avaliações, mas com uma mesma finalidade.

Como justificativa a isso temos uma maior integração com essas avaliações federais, que, de certa forma, são os padrões de avaliação "qualitativa" do ensino brasileiro desde 1995.

Como ressalva, a SEE alega que "mesmo usando a 'régua' do SAEB, isso não significaria que ela não possa interpretar cada ponto da escala a partir dos resultados da aplicação de seus próprios instrumentos, agrupando os diferentes pontos de escala em níveis qualificados de desempenho"48 Como afirma Freitas (2009:60):

\begin{abstract}
Naquela época (a de FHC), fez-se o mesmo movimento quando se articulou o SAEB com os Parâmetros Curriculares Nacionais. O SAEB já existia, mas não havia parâmetros para informar a avaliação articulados ao currículo. O principal esforço da atual proposta repete esse processo. O SARESP já existia, mas não estava articulado ao currículo da escola. Reformulou-se então o currículo para orientar as escolas sobre o que cairá na prova. Como o Estado, ao contrário da federação, é responsável pelo currículo, pode-se, então, formular um currículo obrigatório e não parâmetros. Mas o grupo é o mesmo e o espírito também é o mesmo.
\end{abstract}

Porém, é só a partir de 2008 que as mudanças são implementadas na avaliação. As áreas do conhecimento avaliadas são alternadas ano a ano, sendo todo ano a língua portuguesa e a matemática, e outros anos, alternadamente, ciências humanas (história e geografia) ${ }^{49}$ e ciência da natureza (ciência, física, química e biologia). Anteriormente a 2008, eram somente matemática e língua portuguesa.

Quanto à adequação do SARESP ao currículo em implementação, o documento expressa que a rede pública do estado de São Paulo, em 2007, não tinha um currículo claramente definido para a educação básica. Se as reformas educacionais havidas no Brasil na década de 1990 propuseram, para esse nível de educação, parâmetros e

\footnotetext{
${ }^{48}$ Ibidem, pg. 39.

${ }^{49}$ Como uma espécie de retorno aos estudos sociais.
} 
diretrizes gerais consolidados pela LDB/1996, também delegaram que esses parâmetros e diretrizes fossem desenvolvidos na forma de currículos pelos sistemas de ensino e em projetos pedagógicos nas escolas de todo Brasil.

Entretanto, nem todos os sistemas de ensino fizeram a necessária mediação, em razão do que, em diversos sistemas, cada escola passou a desenvolver sua proposta pedagógica a partir de um currículo presumido, muitas vezes inspirados nos livros didáticos.

Dito isso, o documento afirma o seguinte:

Em São Paulo não foi diferente e, em que pesem boas experiências desenvolvidas em algumas escolas, não havia parâmetros de equidade sistêmica entre elas, desde que, cada qual praticava seu currículo. Houve então a necessidade de se diagnosticar criticamente a existência dos muitos currículos, implícitos ou não, praticados nas escolas da rede estadual, e de se tomar uma firme decisão em favor do estabelecimento de um currículo mínimo e comum a todas as escolas, de forma explícita, para todo o sistema em cujo contorno e definição deveriam estar configuradas e indicadas as bases dos conhecimentos e das competências e habilidades a serem desenvolvidas pelos alunos na escola e, com elas, a indicação das expectativas de aprendizagem para cada série e/ano e ciclo, possíveis de serem avaliadas ao fim de cada um deles, com transparência e eficácia." ${ }^{" 50}$

Com isso, a SEE justifica um currículo e uma avaliação comuns na base da legislação, padronizando as estratégias e procedimentos inerentes ao processo educativo, como na federação.

Com as habilidades e competências da cada área do conhecimento, juntamente com os conteúdos, há uma padronização do processo de aprendizagem, minimizando o currículo aos cadernos e documentos produzidos e publicados para cada área e desprezando, o que é mais grave, as especificidades e a relação prática-teoria de cada escola, de cada região, de cada realidade. Eis aqui um exemplo da relação tema de ensino e competências que são esperadas e avaliadas do aluno:

\section{Quadro 4}

\footnotetext{
${ }^{50}$ Ibidem, pg. 39.
} 


\section{Matriz de referência para avaliação de rendimento do SARESP - 6 a série do Ensino Fundamental II (2009)}

\begin{tabular}{|c|c|}
\hline & Competências \\
\hline 1 & $\begin{array}{l}\text { Compreender as distintas manifestações espaçotemporais na dinâmica da natureza e na } \\
\text { produção dos objetos sociais, de modo a entender o papel das sociedades na produção do } \\
\text { território,da paisagem e do lugar. }\end{array}$ \\
\hline $\begin{array}{c}\text { Tema } \\
1\end{array}$ & A Paisagem e suas manifestações. \\
\hline 2 & $\begin{array}{l}\text { Compreender a diversidade do espaço geográfico brasileiro em diferentes escalas, nas suas } \\
\text { dimensões sociopolítica, material, cultural e natural, como um meio para construir o sentimento } \\
\text { de pertencimento e de identidade nacional. }\end{array}$ \\
\hline $\begin{array}{c}\text { Tema } \\
2\end{array}$ & Espaço geográfico brasileiro em suas diferentes escalas. \\
\hline 3 & $\begin{array}{l}\text { Caracterizar os principais biomas e entender como diferentes grupos sociais se apropriam e } \\
\text { modificam a natureza e as intencionalidades presentes nas alterações ambientais para poder } \\
\text { se posicionar como cidadão atuante e agente responsável pela preservação da natureza. }\end{array}$ \\
\hline $\begin{array}{c}\text { Tema } \\
3\end{array}$ & Patrimônio ambiental e sociedade. \\
\hline 4 & $\begin{array}{l}\text { Utilizar os produtos e as técnicas cartográficas como linguagem para compreender e decodificar } \\
\text { informações de modo a localizar-se no espaço e representar a espacialidade dos fenômenos } \\
\text { geográficos. }\end{array}$ \\
\hline $\begin{array}{c}\text { Tema } \\
4\end{array}$ & A linguagem cartográfica. \\
\hline 5 & $\begin{array}{l}\text { Reconhecer princípios e mecanismos que regem os tempos da natureza e o tempo social } \\
\text { considerando permanências, mudanças e intencionalidades, para compreender a importância } \\
\text { das diferentes escalas espaço-temporais na multiplicidade de vivências nos lugares. }\end{array}$ \\
\hline $\begin{array}{c}\text { Tema } \\
5\end{array}$ & O tempo da natureza e o tempo social. \\
\hline 6 & $\begin{array}{l}\text { Compreender as diferentes formas de organização e regionalização do espaço geográfico, em } \\
\text { suas dimensões sociopolíticas, materiais e culturais, considerando diferentes escalas para agir } \\
\text { de forma crítica, ética e solidária, promovendo a consciência social e o respeito à igualdade e } \\
\text { diversidade entre povos e culturas. }\end{array}$ \\
\hline $\begin{array}{c}\text { Tema } \\
6\end{array}$ & O território brasileiro. \\
\hline 7 & $\begin{array}{l}\text { Compreender os processos histórico-geográficos responsáveis pelo crescimento, distribuição e } \\
\text { composição étnica da população brasileira, com vistas a estabelecer relações entre demografia } \\
\text { humana, urbanização e as diferentes formas de apropriação do espaço geográfico brasileiro. }\end{array}$ \\
\hline $\begin{array}{c}\text { Tema } \\
7\end{array}$ & A população brasileira. \\
\hline
\end{tabular}


Fonte: São Paulo. Matrizes de Referência de Avaliação Educacional. Documento Básico, SARESP. Secretaria Estadual de Educação. CENP. São Paulo, 2009.

Nesse quadro observamos que são esperadas sete competências em cada série avaliada. Dentro dessas competências, estão diluídas as habilidades no processo ensino-aprendizagem.

Essa avaliação estadual foi dividida em matrizes de referência, organizados pela SEE, que construiu o novo currículo, tendo em seguida uma leitura crítica e intervenções por parte de especialistas da CENP, discutidas com os professores coordenadores em todas diretorias de ensino, através de reuniões técnicas e oficinas, das áreas envolvidas na avaliação.

Segundo o documento:

No campo da Educação, é fundamental definir uma matriz de referência em situações de aprendizagem e ensino. Por esse intermédio pode-se avaliar, mesmo que de modo indireto e inferencial, a ocorrência de efetiva aprendizagem. Pode-se, ainda, estabelecer correspondências entre uma situação (o ensino e a aprendizagem em sala de aula) e outra (o que é legítimo de ser avaliado em uma prova, por exemplo). Quanto ao instrumento de avaliação em si mesmo, pode-se comparar a matriz de referência proposta (em sua perspectiva geral) com as habilidades aferidas nesse instrumento específico". (Ibidem, pg. 39)

A ideia então é especificar o que é generalizado através das habilidades e competências do aluno, sendo este foco objetivado de conclusões sobre a realidade de uma escola toda, de uma rede toda, através do SARESP. E isso beira ao irreal, como afirma Freitas (2009:61):

As consequências do modelo de avaliação não tardam e é a própria Secretaria, em seus vídeos, quem admite ter detectado na rede paulista tentativas de se preparar os alunos para o SARESP via simulado. Esta é a questão: quando se estabelece uma avaliação, ela gera uma tradição de exame que orienta professores e alunos. E se houver bônus por desempenho, então, este efeito é potencializado. As escolas tenderão a preparar seus alunos com simulados.

$\mathrm{Na}$ prática, todos na comunidade escolar vivem para ser bem avaliados, bonificados; o aprender se torna uma questão menor. A escola se torna uma fábrica, 
onde a produção não tem muito significado para o operário e sim sua remuneração a partir de sua eficiência produtiva.

Tal documento trás também uma correlação entre as avaliações propostas pelo professor em sala de aula e a proposta pela SEE. Em sala de aula, esse professor estabelece mecanismos avaliativos para um acompanhamento e desenvolvimento de seus alunos, de uma dada turma, através de habilidades especificadas na matriz, tendo em vista o cumprimento da proposta curricular no ano letivo.

Por outro lado, numa avaliação de larga escala, com indicação de habilidades e competências básicas a serem desenvolvidas pelos alunos, em cada etapa da escolarização, reafirma-se $\mathrm{o}$ suposto compromisso da SEE em monitorar o desenvolvimento do plano de metas vinculado à melhoria da qualidade da educação, de forma a promover ajustes necessários para que os alunos tenham acesso a construção dos conhecimentos a que têm direito.

Resumindo, o aluno tem direito aquilo que é previsto, como conhecimento, definido por não mais que uma dezena de especialistas e burocratas ligados à rede, de acordo a interesses ligados ao sistema capitalista vigente. $E$ ao professor não é dado o direito de discutir métodos de avaliação próprias com os técnicos que avaliam os desempenhos encontrados no SARESP. Contanto não há uma avaliação da avaliação.

Sendo assim, as avaliações que acontecem em sala de aula, muitas vezes, não trazem nenhuma referência e articulação com os resultados do SARESP, e nem como foi possivel chegar a tal resultado.

Com isso, os resultados devem ser lidos por si mesmo. Dizem tudo, negando a compreensão do processo educacional como um todo.

No SARESP, com suas mudanças implementadas a partir de 2007 , sua matriz foi elaborada a partir da nova proposta curricular em andamento.

Os conteúdos, competências e habilidades apontados na proposta, para cada série e disciplina do currículo, indicam as bases conceituais da matriz proposta para avaliação. 
Os indicadores relativos a esta posição são obtidos por uma escala de proficiência, por intermédio da qual se define o quanto e o quê cada aluno ou escola realizaram no contexto desse exame.

E essa proficiência é baseada na mesma métrica utilizada pelo SAEB, que é o exame de referência nacional para a Educação Básica no Brasil, criando a possibilidade de um efeito comparativo entre os alunos paulistas e brasileiros como um todo.

Então se estabelece a seguinte relação no processo de ensino e avaliação: conteúdos, escala de proficiência ${ }^{51}$, níveis de desempenho, habilidades ${ }^{52}$, competências ${ }^{53}$, as áreas do conhecimento avaliadas e a avaliação centralizando todos esses anteriores.

Como afirmado no documento, a aprendizagem efetiva se consolida a partir de competências específicas, relacionadas com as habilidades também específicas de cada área, através de uma avaliação externa.

Mas essa metodologia proposta apenas oculta a realidade vivida, cotidiana, autônoma da construção histórica de uma dada escola, sendo colocado como alternativa sim uma avaliação, mas que seja feita de uma maneira mais participativa aos atores que vivenciam tal realidade, como afirma Freitas (2009:61):

Tem a ver com construir um coletivo que pensa a escola - não apenas na hora de avaliar dados de verificações externas. Tem a ver com a avaliação institucional participativa da escola, pela escola e para a escola.

\footnotetext{
51 "Sintetiza o domínio dos conteúdos e habilidades alcançados, o que permiti inferir o nível de domínio das competências avaliadas." (Ibidem, pg. 39) O que realmente é estranho seria o como se mede o grau de proficiência na rede estadual, já que seu parâmetro é o SAEB, de escala nacional, com suas peculiaridades e especificidades, dentro de um país ou mesmo estado tão grande quanto os nossos?

52 "As habilidades possibilitam inferir, pela Escala de Proficiência adotada, o nível em que os alunos dominam as competências cognitivas, avaliadas relativamente aos conteúdos das disciplinas e em cada série ou ano escolares. Os conteúdos e as competências (formas de raciocinar e tomar decisões) correspondem, assim, às diferentes habilidades a serem consideradas nas respostas às diferentes questões ou tarefas das provas. Elas funcionam como indicadores ou descritores das aprendizagens que se espera os alunos terem realizado no período avaliado. Possibilitam, igualmente, pelo nível alcançado, ordenar posições e localizar cada escola, por intermédio do desempenho de seus alunos, no conjunto das escolas ou sistema educacional do estado de São Paulo.”(Ibidem, pg. 39)

53 "A matriz representa um recorte dos conteúdos do currículo e também privilegia algumas competências e habilidades a eles associadas. Ela não faz uma varredura de todas as aprendizagens que o currículo possibilita. Retrata as estruturas conceituais mais gerais das disciplinas e também as competências mais gerais dos alunos (como sujeitos do conhecimento), que se traduzem em habilidades específicas, estas sim responsáveis pelas aprendizagens....as competências, relacionadas a suas habilidades correspondentes, avaliadas no SARESP, podem ser divididas da seguinte forma: competências para observar, competências para realizar e competências para compreender." (Ibidem, pg. 39)
} 
$\mathrm{Na}$ prática, há um interesse maior nos índices educacionais gerados com a execução do SARESP, do que a real melhoria do ensino e aprendizado dos alunos das unidades escolares.

Com isso, lançamos ideias para se pensar numa avaliação como necessária para o bom desenvolvimento educacional de uma escola ou rede, mas refletindo sobre quais métodos utilizar e quão relacionada ela estará com o currículo e seu projeto político-pedagógico das diferentes escolas.

\subsection{4}

\section{Materiais Suplementares a Implementação da Proposta Curricular}

Muitos materiais foram construídos, publicados e encaminhados para as escolas como apoio a essa nova proposta curricular. A orientação de como operacionalizar esses materiais foi construída também pela SEE, através de um documento intitulado "Materiais Suplementares a Implementação da Proposta".

Nele, os professores e gestores encontram, de uma forma simplificada, os principais instrumentos e materiais inerentes a essa proposta.

Sem formação e participação dos professores na construção da Proposta, o documento serve como uma orientação para as escolas, tendo, de início, uma estratégia de convencimento e ocultação das prerrogativas democráticas não expostas desde a apresentação do novo currículo.

Como destaque central, segundo os próprios especialistas construtores desse novo currículo, os cadernos, estilo manual de trabalho, são centrais, mas não únicos.

Como estrutura básica da proposta para os ensinos fundamental II e médio, o documento em questão ${ }^{54}$ aponta os cadernos do aluno, do professor e do gestor como

\footnotetext{
${ }^{54}$ São Paulo. "Proposta Pedagógica: Materiais de suporte a implementação", Secretária de Educação, São Paulo, sem data. Como referencial teórico, para efeito de comparação, são usados as competências do ENEM.
} 
essenciais, dentro de um objetivo central, chamado de Projeto Político Central, que se supõe ser o processo de aprendizagem.

Para completar essa estrutura, temos o SARESP como instrumento avaliativo. Complementando essa relação, de uma forma mais externa ao processo de aprendizagem em si, existem os cadernos que expõem as diretrizes curriculares da rede estadual, dividido por áreas do conhecimento.

A seguir, a proposta é fazer uma breve exploração desses cadernos, onde, há possibilidades de se analisar especificamente suas funções, dando sentido a abordagem até então trabalhada.

\subsection{Uma análise da Geografia no currículo da rede estadual de ensino de São Paulo}

$\mathrm{Na}$ apresentação e introdução ao documento da proposta curricular do estado de São Paulo para o ensino de geografia, é visível uma preocupação de pensar as transformações vividas a partir de uma crítica ao ensino tradicional, fundamentado na memorização de fatos e conceitos, conduzidos para um conhecimento enciclopedista.

Como justificativa a isso, tais críticas nascem de uma necessidade, de alguns segmentos da sociedade, inclusive aqueles engajados na democratização do país, de se estabelecer à dimensão de tempo na investigação do espaço geográfico, de forma a desvendar as origens e os processos de evolução dos diferentes fenômenos geográficos.

Com isso, há uma tentativa de rompimento de um padrão supostamente neutro da Geografia para uma ciência social engajada e atuante no mundo globalizado dos mercados.

No que se refere ao documento da proposta, a geografia deveria estudar as mudanças nas relações de trabalho, as questões ambientais e etnoculturais, indo além 
da dicotomia sociedade-natureza que encara o conceito espacial como uma entidade cartesiana e absoluta, num processo linearizado.

Essa tendência já é pensada e discutida pela SEE desde a deliberação da LDB/96, reformulando o currículo já existente dentro de nosso estado.

Na década de 1990, com o reflexo da LDB, o MEC publicou os PCNs, reforçando a crítica ao ensino conteudista e propondo o ensino por competências.

Como cita a Proposta (2008:42):

Entretanto, em momento algum, o currículo por competências prescinde de conteúdos estruturadores. As competências só podem ser desenvolvidas se houver um ensino que privilegie a aprendizagem de conteúdos mediados por contextos significativos, ou por situações-problema, representativos do cotidiano do aluno.

No contraponto disso, Oliveira (1999) diz que a concepção pedagógica implícita, presente no PCN de Geografia, revela a adoção de uma visão conteudista e individualista. Trata-se, pois, de uma visão centrada no ensinamento de conteúdos pretensamente atuais e modernos, desprovidos de uma concepção formadora que permita a construção da autonomia do aluno.

Oliveira (1999) vai além dizendo que a ausência de uma concepção explícita revela também o desdém com que a educação foi tratada. Os autores ignoraram a necessidade premente de mostrar uma concepção pedagógica. Assim o texto se desenvolve sem que o desenvolvimento psicossocial e histórico da criança/adolescente fossem levados em consideração, tratando-se de um desrespeito ao aluno e ao professor, e um desconhecimento da história da educação.

Com uma divergência aparente, principalmente ao que nos remete o ensino de conteúdos, otimizados pelas freqüentes discussões sobre a renovação da geografia, nos PCNs e na proposta, Kaercher (2006) explora que para haver tal renovação (ou mesmo uma geografia crítica), não basta mudar os temas ou atualizar as aulas de geografia. É preciso também haver uma mudança metodológica que altere a relação professor-aluno, relação esta que, via de regra, continua fria, distante e burocrática. 
E isso não é previsto na atual proposta curricular do estado de São Paulo. Há uma preocupação incessante em realocar conteúdos geográficos em torno da sociedade informacional ligada as novas tecnologias. Mas em nenhum momento é prevista a mudança estrutural nas escolas, nas condições do trabalho ou mesmo na discussão de métodos que qualifiquem a relação professor-aluno-escola.

Silva (2002) afirma, ainda referente ao conteúdo, que é um recorte que parte de um conjunto de procedimentos mais parecidos com a prática jornalística, grávida de informações, cuja finalidade das aulas de geografia passa a ser o acesso à informação, distanciando-se da abordagem geográfica sob o ponto de vista pedagógico dessas mesmas informações.

Oliva (1999) vai nesse caminho também, afirmando que corremos um risco, produzido pelo grande desvio jornalístico que a comunicação em larga escala no país vem sofrendo, que diz respeito à autonomia e especificidade exagerada, atribuídas à chamada dimensão pedagógica do processo de ensino.

Com isso, a geografia é banalizada e superficializada, se tornando um foco de busca de informações atuais e voltadas para o senso comum. Os métodos são desprezados e os conteúdos tornam-se meros segmentos deslocados da realidade, fragmentados e voltados para um fim, e não mais como um meio, na busca de um entendimento e de um significado dos não geógrafos. Portanto, não se forma e nem informa.

Portanto, essa proposta curricular não trás muita coisa nova, em relação aos debates curriculares anteriores no estado. Ela não rompe com a geografia tradicional e nem mesmo consolida uma geografia mais crítica. Não supera a questão conteudista e despreza o papel do professor e os métodos utilizados em sala de aula.

Além de estar num paradoxo de concepção geográfica, a proposta não prevê e nem justifica o "como" tal prática de ensino e aprendizagem chega até as salas de aulas de uma forma eficiente, ou seja, aulas de geografia que tenham significado tanto para o aluno como para o professor.

Como está registrado nos Anais do $4^{\circ}$ Encontro nacional de Geógrafos (1980:357): 
[...] uma tentativa coletiva de rompimento com a Geografia Tradicional. Um rompimento que já se manifestava ao nível da produção teórica nos escritos da 'Geografia Nova'. Um rompimento, porém, que não chegou às salas de aula. $E$ é essa a nova tentativa: trazer para as salas de aula todos os questionamentos e as novas visões da Geografia.

Kaercher (2006) diz que é preciso haver também uma postura renovada de maior diálogo, não só entre professor e aluno, mas com o próprio conhecimento. Devemos ensinar mais nossos alunos (e a nós mesmos) a duvidarem do que se ouve e lê, inclusive nos livros e na televisão, para que o aluno perceba que não estamos, quando se dá aula, ensinando doutrinas, verdades, mas sim que estamos construindo um conhecimento novo a partir do que já temos (a fala do professor, do aluno, o livro texto, os meios de comunicação, etc). Assim se terá uma clareza maior sobre as reais intenções de se ensinar à geografia de uma maneira crítica, contestatória.

A proposta em si faz um discurso teórico de rompimento da geografia tradicional, mas não rompe. Faz uma crítica ao ensino e aprendizagem baseada nos conteúdos, mas não consegue se desvencilhar deles, mesmo com as competências. Despreza a questão da formação dos professores, na concepção de seus conhecimentos e na metodologia.

Sobre tal proposta, Regalo \& Nunes afirma que os professores atuais, conscientes da necessidade de um estudo contínuo, munidos de novos conhecimentos e melhor capacitados, poderão ensinar aos seus alunos a geografia pela concepção da dialética materialista, mostrando claramente em suas análises que a história é o grande motor das transformações e que o espaço geográfico está impregnado de ações históricas realizadas pelos grupos sociais.

Enfim, que a Geografia sirva para formar alunos com uma visão de mundo universalista, crítica, engajada, de inclusão social e não esta que tem sido ensinada na maioria das escolas, que apenas avalia a quantificação dos números expostos, que não questiona os modelos, que não discute o porquê de tamanhas desigualdades sociais, que se conforma com a situação existente no país, que ensina apenas reproduzindo e não transformando os seres humanos. 
A seguir, vamos discorrer as relações entre os PCNs, a Proposta Curricular do estado de São Paulo e a geografia.

\subsubsection{Os Parâmetros Curriculares Nacionais, a Geografia e a Proposta Curricular do Estado de São Paulo}

Os Parâmetros Curriculares Nacionais (PCN), elaborado pela Secretaria de Educação Fundamental do Ministério da Educação e do Desporto, em 1998, destinados a todos os interessados no sistema educacional, constituem-se como uma proposta de orientação curricular voltada para o "resgate e construção da cidadania no ensino básico brasileiro". Este documento regulamenta o instrumento legal da Lei de Diretrizes e Bases da Educação Nacional, Lei n 9394, de 20 de dezembro de 1996.

Segundo os PCN, além de garantir a formação de cidadão através da ampliação de ofertas de vagas nas escolas de ensino fundamental, faz-se necessário uma revisão curricular que oriente os professores para um ensino que incorpore em seu trabalho os avanços das pesquisas nas diferentes áreas de conhecimento.

E isso, de certa forma, justifica e norteia as ações da nova Proposta Curricular do Estado de São Paulo. Assim como afirma Kobayashi (2001:105):

É interessante destacar que os PCN deverão ser, segundo o que nos foi possível entender, o referencial para discussão de conhecimentos de relevância social em que se desenvolvam projetos educativos nas diversas instâncias municipais, estaduais, ou locais.

Os PCN propõem o conteúdo curricular como uma proposta flexível, aberta e que deverá ser concretizada nas instâncias locais, caracterizando já, de início, um risco, devido aos meios de como isso seria possível.

Mas, como o que nos interessa, nesse momento, é o ensino de geografia, vamos nos ater a ele. 
Segundo Oliveira (1999), a história do pensamento geográfico no final do século XX está marcada por um intenso debate entre positivismo clássico, o empirismo lógico, o historicismo, a dialética e a fenomenologia. A influência marxista deixou marcas profundas e, ignorá-la, é ignorar a história do século XXI. Ou melhor, é instrumentalizar o Estado capitalista ideologicamente.

Logo a discussão sobre a história do pensamento geográfico é página aberta. E com os autores dos PCNs não foi diferente.

Segundo Kobayashi (2001), os PCNs fazem uma breve revisão histórica da proposta de currículo para o ensino fundamental, onde se destacam duas correntes: a geografia tradicional e a geografia crítica.

Com isso, os PCNs trazem uma suposta proposta de superação da geografia tradicional, enfatizando a geografia crítica, onde tais concepções, longe do consenso da utilização ou mesmo rotulação, certamente são expressões que foram difundidas nas análises do ensino da geografia escolar.

A geografia tradicional é caracterizada por uma tendência Lablachiana e das correntes que dela se desdobraram a partir da década de 1960. Valorizando o papel do homem como sujeito histórico, essa tendência se limitava a análise da organização do espaço como lugar e território e as relações entre o homem e a natureza mais como processos de adaptações. Estudavam-se as populações e os homens como coisas objetivas, nas quais a sociedade e o espaço emergiam das ações humanas desprovidas de quaisquer intencionalidades ou ideologias, como afirma $\mathrm{PCN} 3^{\circ}$ e $4^{\circ}$ ciclos (1997).

No ensino, essa corrente se traduziu pelo estudo descritivo das paisagens naturais e humanizadas, de forma dissociada dos sentimentos dos homens pelo espaço. Os procedimentos didáticos adotados promoviam principalmente a descrição e a memorização dos elementos que compõem as paisagens como dimensão observável do território e do lugar. Afinal, quem como professor de geografia já não foi questionado da seguinte forma: Qual capital de tal país? Se caso não soubesse a resposta, era taxado como um mal professor. 
Já a geografia crítica veio contestar essa corrente da geografia tradicional, justificando que esses métodos e teorias tornaram-se insuficientes para apreender a complexidade do espaço. Era então necessário realizar estudos voltados para a análise das ideologias políticas, econômicas e sociais.

A partir dos anos de 1960, sob a influência das teorias marxistas, as preocupações se voltaram para as relações entre sociedade, o trabalho e a natureza na produção e apropriação dos lugares e territórios. Criticou-se assim uma geografia que naturalizava a ação do estado e das classes sociais dominantes, propondo uma geografia das denúncias e das lutas sociais como afirma PCN $3^{\circ}$ e $4^{\circ}$ ciclos (1997)

$E$ isso, de certa forma, é interpretado pelos $\mathrm{PCNs}$ como duas concepções que apresentam insuficiências metodológicas que fazem crer que o próprio documento quer legitimar e defender uma concepção própria de geografia. E essa concepção, segundo Kobayashi (2001) se aproxima muito do que chamamos de Geografia Humanista, que carrega uma contribuição teórica e metodológica dada pela fenomenologia.

Já Oliveira (1999) afirma que os autores dos PCNs de geografia optaram por não deixar claramente explicitada a concepção de geografia que têm. Agindo dessa forma, deixaram abertas múltiplas possibilidades de interpretações. Ele afirma que houve um veio humanista atravessado pelo historicismo clássico, referências à natureza baseadas no positivismo clássico e em seguida, o marxismo.

E completa dizendo que estas diferentes concepções da ciência geográfica presente no texto permitem que se afirme que os autores adotaram a concepção de geografia baseada no ecletismo. Tal ecletismo revela mais a ausência do que a presença de uma concepção filosófica da geografia.

Dito isso, identificamos semelhanças entre as concepções geográficas dos PCNs e da Proposta Curricular do Estado de São Paulo. Além de utilizar o mesmo discurso de superação da geografia tradicional em detrimento da geografia crítica, a proposta propõe uma geografia enquanto "ciência social engajada e atuante num mundo cada vez mais dominado pela globalização dos mercados, pelas mudanças no trabalho e pela urgência das questões ambientais e etnoculturais". Proposta (2008:41). 
Além de propor essas concepções, a Proposta se apresenta mais eclética ainda trazendo a necessidade de priorizar discussões em torno da sociedade informacional dos tempos de hoje - onde, a meu ver, não é específico da geografia - e sim de todas as áreas do conhecimento.

A Proposta (2008) afirma que uma nova concepção de geografia deve, com urgência, priorizar a discussão dos desafios impostos pelas transformações do meio técnico-científico-informacional, inserido em sala de aula e fora dela - em especial, a partir do advento da comunicação on-line, responsável por influir e modificar o local, o regional e o global simultaneamente.

Em relação aos conteúdos, as propostas são semelhantes, sendo chamados de categorias tanto pelos PCNs quanto pela Proposta.

Assim foi descrita pelo $\mathrm{PCN} 1^{\circ}$ e $2^{\circ}$ ciclo (1997:110):

No que se refere ao ensino fundamental, é importante considerar quais são as categorias de Geografia mais adequadas para os alunos em relação à sua faixa etária...Embora o espaço geográfico deva ser o objeto central de estudo, as categorias paisagem, território e lugar devem também ser abordadas, principalmente nos ciclos iniciais, quando se mostram mais acessíveis aos alunos, tendo em vista suas características cognitivas e afetivas.

E na Proposta $(2008: 44,45)$ foi descrito assim:

O objeto central do ensino da Geografia reside, portanto, no estudo do espaço geográfico, abrangendo o conjunto de relações que se estabelece entre os objetos naturais e os construídos pela atividade humana, ou seja, os artefatos sociais...O ensino de Geografia na educação básica deve priorizar o estudo do território, da paisagem e do lugar em suas diferentes escalas...

Oliveira (1999) trás para o debate essas questões teóricas inerentes ao documento dos PCNs, referentes ao conjunto de noções, conceitos e categorias. Segundo ele, os aspectos teóricos não tiveram, por parte dos autores, um cuidado especial, sendo comum encontrar-se a mesma palavra sendo tratada ora de uma forma, ora de outra. Foi o que aconteceu com as chamadas categorias espaço, território, paisagem e lugar. 
Neste PCN, é comum encontrarmos situações em que se destaca a importância de o professor trabalhar determinado tema, ou mesmo, situações em que são sugeridos procedimentos gerais ou específicos da ciência geográfica. Mas muitas vezes não são especificados o "como" fazê-los.

E isso é presente também na Proposta Curricular do estado de São Paulo. A seguir, vamos expor as condições estruturadoras de um ensino e aprendizagem em geografia, nessa proposta, juntamente com os conteúdos e métodos expostos através de cadernos didáticos que chamaremos de cartilha.

\subsubsection{Ensino e aprendizagem em geografia: conteúdos}

O processo de ensino e aprendizagem nas escolas é inseparável. Qualquer política pública para a educação tem que estar contemplada com as várias facetas de tal processo. O componente curricular está imbricado em ensino e aprendizagem. E na geografia não é diferente.

Oliveira (2006) afirma que o binômio ensino/aprendizagem apresenta duas faces de uma mesma moeda. Uma é causa e a outra consequência. E vive-versa. Isso porque o ensino/aprendizagem é um processo que implica movimento, atividade e dinamismo; é um ir e um vir continuadamente. Ensina-se aprendendo e aprende-se ensinando.

A aprendizagem é tudo que, no processo do desenvolvimento mental, não é determinado hereditariamente, ou seja, pela maturação, considerando toda a aquisição obtida ao longo do tempo, isto é, mediata e não imediata, como a percepção ou a compreensão instantânea. Como afirma Oliveira (2006:217): "A aprendizagem não será 
produzida pela simples acumulação passiva, mas mediante a atividade exercida sobre os conteúdos, articulando-se uns com os outros".

Por outro lado, ensinar é provocar situações, desencadear processos e utilizar mecanismos intelectuais requeridos pela aprendizagem, que permitirá aos professores empregarem métodos ativos, para engendrar a ação didática em bases sólidas, evitando tentativas ou ensaios e práticas infrutíferas, demasiadamente perigosos, sobretudo quando as ações são exercidas sobre crianças e adolescentes.

Considerando isso, é de essencial análise os conteúdos e métodos que direcionam tal proposta, assim como as cartilhas didáticas presentes no currículo.

Segundo Paganelli (2006), a seleção e organização dos conteúdos e dos conceitos constituem um item de todo e qualquer planejamento curricular de ensino, seja um plano anual, seja uma unidade ou aula.

Em princípio, são conteúdos que se estabeleceu e se estabelece, como o contido em um campo de uma ciência que é a ciência geográfica e o seu ensino, num determinado contexto.

Para alguns pesquisadores, segundo Paganelli (2006), esses conteúdos geográficos compreendem as práticas dos geógrafos, dos professores de geografia, das instituições de uma sociedade, em um determinado momento histórico; para outros, compreende o saber pensar o espaço na geografia, ou seja, as práticas sociais dominantes tanto dos Estados Maiores como da prática dos professores.

Lacoste (1976) distingue uma prática dos Estados Maiores e dos professores. Escolar (1996) apud Paganelli (2006) distingue, no discurso dos geógrafos, uma geografia acadêmica, dos professores, das instituições e do cotidiano, que fundamenta a seleção e a organização de conteúdos no ensino, em geral.

Neste momento, contradizemos Kaercher (2006), pelo menos em parte. Há de se ter uma preocupação específica com a aprendizagem de conteúdos, mas este não vem desvinculado da prática, do método. Esse mesmo autor tem razão quando afirma que é preciso haver uma mudança metodológica que altere a relação professor-aluno, mas 
isso não pode ser desvinculado dos conteúdos geográficos e da formação dos professores.

Pontuschka, Paganelli \& Cacete (2007) completam essa ideia afirmando que a disciplina escolar geografia mantém vínculos com a respectiva ciência por meio dos conceitos, métodos e teorias geográficas, onde os conteúdos disciplinares são organizados a fim de atender a concepções hegemônicas da própria ciência e correspondem a um tempo e espaço específicos, articulados às concepções pedagógicas de organização do currículo e do ensino.

Com isso, lançamos a seguinte hipótese em relação à proposta: há uma valorização demasiada acerca dos conteúdos, onde estes estão desarticulados entre si e em relação aos métodos utilizados, desconfigurando e desqualificando o currículo.

Com isso, de início, é essencial analisar as bases conceituais da proposta, assim como os autores que the embasam.

Dando sustentação teórica a proposta, foram utilizadas e elencadas algumas obras acadêmicas como referências, destacando-se as do professor Milton Santos, as do filósofo Edgar Morin, as do sociólogo Anthony Giddens, bem como as obras de David Harvey e do escritor moçambicano Mia Couto. ${ }^{55}$

A proposta afirma que o objetivo central do ensino da geografia reside no estudo do espaço geográfico, abrangendo o conjunto de relações que se estabelece entre os objetos naturais e os construídos pela atividade humana, ou seja, os artefatos sociais.

Nesse sentido, afirmam que, enquanto o "tempo da natureza" é regulado por processos bioquímicos e físicos, responsáveis pela produção e interação dos objetos naturais, o "tempo histórico" responsabiliza-se por perpetuar as marcas acumuladas pela atividade humana como produtora de artefatos sociais.

A proposta destaca ainda que o ensino de geografia na educação básica deve priorizar o estudo do território, da paisagem e do lugar em suas diferentes escalas, buscando romper com uma visão estática na qual a natureza segue o seu curso

\footnotetext{
${ }^{55}$ SANTOS, Milton. "A natureza do espaço”. São Paulo: Hucitec, 1996; MORIN, E. "Os sete saberes necessários à educação do futuro". São Paulo: Cortez, 2001; GIDDENS, A. "Mundo em descontrole". Rio de Janeiro: Record, 2000; HARVEY, D. “Condição pós-moderna"; COUTO, Mia. "Pensatempos”. Lisboa: Editorial Caminho, 2004.
} 
imutável e irreal, enquanto a humanidade é vista como uma entidade a ser estudada à parte, como se não interagisse com o meio.

Segundo Regalo \& Nunes (2009), trata-se de um delineamento idealista e sincrético, notadamente pautado nas concepções mais conservadoras desse campo.

Mas ainda podemos seguir uma reflexão dos conteúdos acerca do distanciamento da disciplina geografia, generalizando o aprendizado, e se aproximando com as demais disciplinas que representam as ciências humanas.

Como diz ainda Regalo \& Nunes (2009:114):

Frente aos fundamentos arrolados, se tomamos a geografia como ciência da sociedade, seu objeto deverá ser um juízo e análise de um segmento específico da realidade social, assim, ela discutirá processos sociais e os fenômenos da natureza interessar-Ihe-ão apenas enquanto recurso para a vida humana. Ela não discutirá os processos naturais em si, mas tão somente a natureza para o homem. Sua ótica estará bem centrada no movimento da sociedade, a partir de seus condicionantes econômicos e políticos e, dessa forma, seus instrumentos de pesquisa serão parecidos com os das demais ciências humanas.

A escolha dos autores como referência, no caso da proposta paulista, reforça a dualidade da escolha epistemológica acima citada. Os autores arrolados possuem uma vasta obra já publicada, mas assumem linhas epistemológicas também diferentes.

Com isso, Regalo \& Nunes afirmam que nessa proposta são utilizados autores da escola tradicional, como David Harvey e, da escola crítica, Milton Santos e o sociólogo Edgar Morin.

Assim como justifica Andrade (1989:31-2) em relação a David Harvey e seus posicionamentos:

Surgem então posições as mais diversas como aqueles que se mantém fiéis ao neopositivismo e à tecnocracia e procuram manter os modelos como metas a serem analisadas, como se o Brasil estivesse em uma camisa de força; os que abandonaram o neopositivismo e passaram a ler os filósofos dialéticos dentro de uma ótica positivista, como ocorre nos Estados Unidos com David Harvey; e os que sempre tiveram uma posição crítica, que resistiram às vantagens de uma adesão ao neopositivismo e analisaram, baseados na práxis, a realidade vivida, o processo de apropriação e de modelação do espaço pela sociedade. Pode-se assim passar de uma Geografia no Brasil, mas com raízes estrangeiras, para uma Geografia do Brasil que, embora não ignorando os 
princípios científicos internacionais, faça uma análise autêntica das relações entre a sociedade e o espaço brasileiro.

Nos trabalhos do professor Milton Santos, principalmente a obra Por uma Geografia Nova, lançada em 1978, acabou influenciando vários geógrafos brasileiros e, consequentemente, toda área em questão. Há nesses trabalhos uma avaliação crítica da geografia tradicional, destacando a crise do pensamento geográfico, apresentando as principais propostas de renovação, inclusive no ensino.

Para esse autor, o que é enfatizado é toda atividade produtiva dos homens, implicando numa ação sobre a superfície terrestre, numa criação de novas formas, de tal modo que produzir é produzir espaço, numa organização do espaço determinada pela tecnologia, pela cultura pela organização social da sociedade, mediada pelo capital, através da acumulação capitalista.

Já para Edgar Morin há uma necessidade de integrar os conhecimentos para permitir uma mudança de pensamento; para que se transforme a concepção fragmentada e dividida do mundo, que impede a visão total da realidade. Para esse autor, trata-se de superar o saber tradicional, impositivo, descritivo e racionalista por um novo saber, de natureza complexa, somente plausível numa nova sociedade, aventada a partir de uma nova consciência planetária e subjetiva.

Com isso, a proposta vem com uma miscelânea de concepções e conteúdos a serem trabalhados nas escolas. Há vários equívocos interpretativos, demonstrando que o texto curricular é fragmentado, desconexo e muitas vezes beira ao superficialismo em sua coerência construtiva.

Assim como indica Regalo \& Nunes (2009:115): "Articular Morin e Santos num único referencial, sem titubeios, beira à artificialidade ou banalização analítica e à miséria interpretativa".

Percebemos assim o quanto há incertezas no trabalho com conteúdos no ensino de geografia, segundo a proposta. Ou mesmo uma intencionalidade incoerente e distante da realidade das aulas de geografia. 
Após análise dos conteúdos, assim como a contextualização das concepções geográficas e seus autores, veremos a seguir considerações acerca dos métodos e práticas inerentes as aulas de geografia.

Com isso nos propomos a fazer considerações sobre as cartilhas didáticas disponibilizadas e utilizadas na rede de ensino pública do estado de São Paulo.

\subsubsection{Metodologia e práticas: as cartilhas didáticas}

No ano de 2007, data do início da implementação curricular, a SEE propõe um currículo flexibilizado que utiliza cartilhas didáticas em todas as disciplinas; do ensino fundamental ao ensino médio.

Com uma perspectiva de um déficit de ensino e aprendizado dos alunos, propõe, num intervalo de 2 meses, a utilização de um material inicial em formato de jornal. Tal material fundamenta algumas estratégias de ensino voltadas para temas voltados a matemática, como interpretação de gráficos e tabelas, utilização de medidas e análise de dados estatísticos.

Com tal estratégia, a SEE interpreta que isso amenizaria os anos de fracasso escolar, criando um diagnóstico de aprendizagem dos alunos.

Com isso, havia uma intenção clara de adaptação dos alunos e professores a essa nova realidade curricular: um sistema de ensino apostilado.

Spósito (2006) afirma que os currículos e os livros didáticos aumentam de importância e desempenham um papel maior do que o desejado. Avaliá-los, assim como avaliar o trabalho docente, é tarefa que se apresenta como fundamental. Essa avaliação só pode ser positiva se for compreendida como processo no qual ela própria deve ser objeto de crítica, como caminho para sua redefinição.

As cartilhas levam os professores a assumir o que lhes propõem, em vez de avaliar e formular uma proposta didática mais apropriada ao desenvolvimento de um projeto pedagógico de sua escola e/ou a um enfoque teórico-metodológico que eles 
próprios possam escolher. Isso fere a autonomia docente. Isso fere a escola e prejudica o ensino-aprendizagem dos alunos.

Mas o que são tais cartilhas?

O projeto de ensino de geografia apresentado nas cartilhas da proposta propõe um currículo para o ensino fundamental ( $5^{\mathrm{a}}$ a $8^{\mathrm{a}}$ série) e para o ensino médio ( $1^{\mathrm{a}}$ a $3^{\mathrm{a}}$ série). Para efeito de pesquisa, abordaremos apenas o ensino fundamental.

Na $5^{a}$ série, o conteúdo é dividido em quatro bimestres e apresenta os seguintes temas: no primeiro bimestre - A paisagem, escalas da geografia; no segundo bimestre - O mundo e suas representações, A linguagem dos mapas; no terceiro bimestre - Os ciclos da natureza e a sociedade; e no quarto bimestre - As atividades econômicas e o espaço geográfico.

$\mathrm{Na} 6^{\mathrm{a}}$ série, o conteúdo é divido em quatro bimestres e apresenta os seguintes temas: no primeiro bimestre - $O$ território brasileiro; no segundo bimestre - $A$ regionalização do território brasileiro; no terceiro bimestre - Domínios morfoclimáticos do Brasil e o Patrimônio ambiental e sua conservação; e no quarto bimestre - Brasil: população e economia.

$\mathrm{Na} 7^{\mathrm{a}}$ série, o conteúdo é dividido em quatro bimestres e apresenta os seguintes temas: no primeiro bimestre - Globalização em três tempos; no segundo bimestre Produção e consumo de energia; no terceiro bimestre - A crise ambiental; e no quarto bimestre - Geografia comparada da América.

$\mathrm{Na} 8^{\mathrm{a}}$ série, o conteúdo é dividido também em quatro bimestres e apresenta os seguintes temas: no primeiro bimestre - A produção do espaço geográfico; no segundo bimestre - A nova desordem mundial; no terceiro bimestre - Geografia das populações; e no quarto bimestre - As redes sociais.

Segundo Regalo \& Nunes (2009), são temas e conceitos que revelam, em sua quase totalidade, a adesão a uma abordagem idealista, generalista e histórica da produção da realidade e seus condicionantes sociais, econômicos, políticos e culturais.

Esse discurso, atraente e inovador do ponto de vista conceitual, tende a se esfacelar quando fazemos uma crítica das cartilhas, que, para Regalo \& Nunes (2009), aponta na direção de um descompasso entre o desenho teórico da cartilha e a parte 
prática da mesma. Há aqui um engodo estrutural entre teoria e prática, para aquém do debate sobre essa nucleação fundamental da epistemologia.

As escolas estaduais têm recebido impressos provenientes da SEE nos quais são destacados os temas teóricos a serem tratados e determinados os conteúdos e concepções a serem seguidos na proposta de uma lista de exercícios. Trata-se de uma imposição.

Os professores são obrigados a trabalharem em sala de aula a linha metodológica enviada pelos gestores e ideólogos da secretaria de estado de São Paulo, onde parece ser destaque importante a atitude de assimilar unilateralmente os conteúdos apresentados e a seguir adquirir condições de resolver os exercícios ao final de cada capítulo.

Regalo \& Nunes (2009) afirmam que é evidente nessa produção que o esquema paradigmático é tradicional e anacrônico, e que o importante é quase que decorar as informações e, em seguida, resolver os exercícios apresentados; seguem afirmando que tal prática é tecnicista, servindo apenas para acumular informações, além de ser um sistema fechado de aprendizagem, sem conexão com outras áreas do conhecimento.

Analisando os conteúdos das séries do ensino fundamental, percebe-se claramente que as cartilhas idealizam o professor típico da educação bancária, já tão questionada pela lúcida proposição de Paulo Freire (2006), que nos lembra a velha e sempre atual lição de que ensinar não é transferir informações ou conhecimentos.

Para exemplificar isso, tomemos como exemplo uma cartilha, de primeiro bimestre, proposta para a $6^{a}$ série do Ensino fundamental.

No início, na cartilha do professor, há orientações sobre os conteúdos a serem trabalhados, assim como as competências e habilidades, metodologia e avaliação.

Há uma indicação clara sobre a continuidade dos trabalhos realizados na série anterior, mas sem definições de como isso poderia acontecer. Na $5^{\mathrm{a}}$ série, o foco de estudo estaria centrado no espaço geográfico, tomando-se por base os conceitos estruturadores de paisagem e lugar. 
Já na $6^{a}$ série, espera-se que o estudante, ao estabelecer relações entre as características socioeconômicas e o quadro natural das diferentes regiões do país ao longo do tempo, desenvolva as primeiras noções de outro conceito: o de território. Mas o caderno trás a seguinte afirmação: que em geografia, território é um termo com muitos outros sentidos, que o aluno da $6^{a}$ série pode ser desafiado a pensar sobre eles, demonstrando competência para recuperar informações e desenvolver suas próprias interpretações.

Mas onde está a intencionalidade do trabalho docente se o aluno passa a ser incentivado a desenvolver suas próprias interpretações? E se realmente isso ocorre, como trabalhar isso? Não há um risco eminente de generalização do conceito ou mesmo um destino para o senso comum? Que informações são esses que os alunos devem recuperar? O conteúdo aqui está sendo utilizado como fim?

O método se torna obscuro, sem sentido, tendo uma tendência a se chegar ao nada; ou mesmo uma mera transferência de informações e conhecimentos.

Outra questão é a utilização dos mapas. Em vários trechos desse caderno, é sugerido o trabalho cartográfico, mas sem nenhuma contextualização de como isso poderia ser feito. Inclusive sugerem a comparação de mapas sem ao menos citar a necessidade de uma alfabetização cartográfica constante, com um ensino e aprendizado voltado para a leitura e produção de mapas.

Como os alunos podem comparar mapas se, ao menos em tese, não conseguem entender, ou mesmo, ter um significado para tal linguagem? Trabalhar com mapa, na visão dos cadernos, é consultá-los e disponibilizá-los; e não ensiná-los.

Como metodologia e estratégias, tais cadernos beiram a superficialidade eminente. Sugerem que os professores proponham uma grande variedade de assuntos tais como exposição, discussão, leitura e recursos individuais. Afinal, o que há de novo nisso? Para quê tais métodos? Isso não é explicitado em momento nenhum.

Com isso, propõem uma tabela orientadora, divididas por tipos e níveis de compreensão, demonstrando o quanto o fator humano no ensino e aprendizado se tornou um mero número, um índice estatístico. Eis a tabela: 


\section{Quadro 6}

Proposta de níveis de compreensão dos alunos esperados pelos professores

\begin{tabular}{|c|c|}
\hline Tipo & Níveis de Compreensão \\
\hline 1 & Identificação de informações isoladas \\
\hline 2 & Comparação de informações fornecidas pelo professor com as \\
incluídas nos textos
\end{tabular}

Fonte: São Paulo. "Caderno do Professor: geografia, ensino fundamental - $6^{\mathrm{a}}$ série,vol 1 , SEE, 2009".

Quanto à avaliação, a cartilha em questão trás como proposta uma sucessão de atividades que, em tese, auxiliaria no processo contínuo e sistemático de avaliação diagnóstica . Em tese porque tais avaliações são padronizadas, sendo oferecido aos professores de geografia fichas de observação individuais e em grupo, como resultados esperados dentro dos objetivos propostos.

Segundo CENPEC (2004), avaliar significa dizer o que está acontecendo na relação ensino-aprendizagem, o quanto foi possível avançar, o que vai bem e o que precisa melhorar na direção do que foi considerado central para aprendizagem dos alunos. Para isso, o professor deverá ter uma visão de conjunto de sua disciplina e ter clareza de onde quer chegar com seu trabalho.

Novamente vemos com isso o desaparecimento da autonomia e criatividade do professor também para avaliar, cerceando sua reflexão, profissionalismo e planejamento de aulas coerentes com os objetivos, em detrimento de padrões préestabelecidos, impostos por tal currículo.

O modelo está exposto abaixo: 


\section{Quadro 7}

Proposta de avaliação e dos objetivos atingidos com a execução das atividades pelos alunos

\begin{tabular}{|l|l|}
\hline \multicolumn{1}{|c|}{ Avaliação das Atividades } & \multicolumn{1}{c|}{ Objetivos Atingidos } \\
\hline 1.Muito Bom & Atingiu plenamente os objetivos propostos \\
\hline 2. Bom & Atingiu grande parte dos objetivos propostos \\
\hline 3. Regular & Atingiu os objetivos mínimos essenciais \\
\hline 4. Insuficiente & Não atingiu os objetivos mínimos essenciais \\
\hline
\end{tabular}

Fonte: São Paulo. "Caderno do Professor: geografia, ensino fundamental - $6^{a}$ série, volume 1, SEE,2009".

É importante salientar que diversos tipos de materiais, tais como livros, mapas, fotos, etc são solicitados para a execução das aulas de geografia, de acordo com as estratégias elencadas. Mas a única referência de como encontrá-los, ou mesmo disponibilizá-los é a indicação de sítios e links na internet. Dado isso, é tirada a autonomia docente, mas, ao mesmo tempo, atribui funções que deveriam estar centralizadas no universo organizacional da escola; assim como a disponibilização de tais materiais.

Dito isso, Pereira (2009) levanta a hipótese que, com o estabelecimento dessa proposta leva ao entendimento inicial de que o principal problema da educação é a falta de preparo do professor.

Com isso, esse problema pode ser resolvido com uma cartilha que determina o conteúdo que o professor vai trabalhar e as formas de desenvolvê-lo, e também com sistemas de avaliações que são utilizados para classificar a qualidade do professor. E diga-se de passagem, qualidade norteada pela capacidade do professor em repassar as informações de tais cartilhas.

A partir disso, me arrisco me afirmar que o professor de geografia perde sua potência como educador, que intencionaliza o ensino e aprendizagem de conteúdos, numa metodologia clara e consistente, atenta aos objetivos pretendidos e propostos em dada circunstância. Ele deixa de ser professor e se torna um mediador, capacitador e facilitador da transferência de informações e conhecimentos geográficos.

É o que veremos a seguir. 


\subsubsection{O projeto político no currículo de Geografia: neoliberalismo e docência}

Certamente, intencionalidades educacionais e políticas são colocadas a prova na implementação desse novo currículo. Se considerarmos como uma política pública, que é formulada para a melhoria do ensino e aprendizagem na rede estadual pública do estado de São Paulo, algumas considerações hão de ser feitas.

Para Sacristán (1998) o sistema curricular é objeto de regulações que são econômicas, políticas e administrativas. Cabe ao currículo o interesse político básico de controlar a educação como sistema não só de ordem técnica e administrativa, mas, também, de forma ideológica.

Coll (1996) afirma que a elaboração de um currículo ocupa um lugar central nos planos de reforma educacional e que frequentemente ele seja considerado como ponto de referência para guiar outras atuações como a formação inicial e permanente do corpo docente, organização dos centros de ensino e a confecção de materiais didáticos.

Com essas ideias, o currículo se apresenta como um centro das políticas educativas e das reformas neoliberais.

Com a incoerência metodológica e de concepção da geografia, a proposta em questão tem como finalidade central apenas criar orientações para as escolas. Essa compreensão parte do princípio que as escolas não podem formar seus próprios programas e currículos se os mesmos já vieram prontos.

Assim não é possível formar um programa para o ensino de geografia de uma determinada unidade escolar, respeitando a diversidade no seu entorno e a realidade vivida pelos educandos, quando o mesmo já vem completamente acabado e direcionado através de uma lista de conteúdos e temas definidos por séries e segmentos educacionais.

Como afirma Ferreira (2009), o objetivo curricular neoliberal tem que servir de ponto de referência para guiar determinadas atuações dentro deste programa, como a 
avaliação e a busca pelas metas de ensino. Seu papel foi de criar padrões para servir de parâmetro para avaliação das escolas.

Com essas premissas, a proposta se apresenta como um retrocesso. No lugar de uma educação libertária, emancipatória, crítica e histórica, optou-se por um recorte teórico conservador, apolítico, repetitório.

Regalo \& Nunes (2009) apontam que a Proposta Curricular do estado de São Paulo sedimenta a educação neoliberal. O material enviado para as escolas tem sido rotulado, pelos próprios professores da rede pública, de apostilas. Estes afirmam que a finalidade de seu uso é unicamente treinar os alunos da rede para a realização das provas do SARESP e do ENEM, em uma clara demonstração de que o que importa é mostrar números de aprovados nas instâncias estatísticas e produtivistas formais.

Assim, a proposta está desvestida de criticidade, de apelos a emancipação. Ela não tem como preocupação central à formação do aluno, crítico, capaz de conhecer sua realidade e posicionar-se pela sua transformação.

A proposta do ex-governador José Serra vem sedimentar a política neoliberal iniciada no governo de Fernando Henrique Cardoso (1995-2002) e de seu ministro da educação, Paulo Renato Souza. Sua inspiração política permaneceu a mesma, como uma política nascida do subserviente alinhamento ao Consenso de Washington, onde ficou definido que na América Latina a educação deixaria de ser uma responsabilidade do Estado e seria transferida paulatinamente para os critérios e disposição da iniciativa privada, com seus métodos pautados na gestão empresarial.

Paulo Freire (2006) afirma que ensinar exige compreender que a educação é uma forma de intervenção no mundo. Ensinar exige reflexão crítica sobre a prática. Aprender não é apenas acumular conhecimentos e repeti-los, mas utilizar o aprendido para interferir no mundo que vivemos. É uma busca constante de um saber que se potencialize em disposições de transformá-lo.

E nisso a figura do professor é central. Nessa proposta, os conhecimentos adquiridos por parte dos alunos são engrenagem fundamental no programa de avaliação das escolas, como já explicitado. Com isso, o objetivo central a proposta foi atrelar o salário dos professores a uma lógica de produtividade. Sendo assim, recebia 
um salário maior os professores pertencentes a uma escola cujos alunos obtiveram maior nota no sistema de avaliação externa.

Tais escolas são avaliadas anualmente de acordo com as metas e padrões estabelecidos pela SEE. Com isso não é possível falar em autonomia de uma escola passando pela construção do seu projeto pedagógico em conjunto com a comunidade, se a mesma tem que seguir um receituário administrativo, pedagógico e político.

Ou seja, os propositores do Estado não enxergam o professor como emancipado para acrescentar elementos às cartilhas, modificar ordem, questionar a pertinência de um tema, reformular nada. O material, assim como a proposta como um todo, deve ser seguida à risca sem questionamentos, ou seja, na prática todos os postulados da geografia crítica são derrubados.

Consciente de toda trama global, temos a necessidade de um novo professor de geografia, que busque gerar uma nova compreensão da realidade social, política e econômica. Que questione o que está posto como supostamente natural ou necessário e que faça a crítica a partir das condições históricas. Esse novo professor tem que deixar de ser um agente de reprodução e se transformar em um agente de transformação social, debatendo com os alunos a forma como os modelos econômicos em curso impactam o espaço geográfico..

Dentro de uma óptica consumista, imediatista, no mundo globalizado de hoje, tudo passa a ser representado como coisa, e, portanto, tudo tem um valor, tudo pode e deve ser consumido. O que importa é produzir e vender.

Se essa óptica é uma preocupação do governo do estado de São Paulo, de teor neoliberal, então verifica-se a necessidade de formar alunos que possuam uma visão de mundo mais abrangente, universalista, que aprendam que todos vivemos em um mesmo mundo, que deve ser preservado para outras gerações em condições melhores do que as atuais.

Enfim, que a geografia sirva para formar alunos com uma visão de mundo crítica, engajada, de inclusão social e não esta que tem sido ensinada na maioria das escolas, que apenas avalia a quantificação dos números expostos, que não questiona os modelos, que não discute o porquê de tamanhas desigualdades sociais, que se 
conforma com a situação existente no estado de São Paulo, que ensina apenas reproduzindo e não transformando os seres.

Regalo \& Nunes (2009) finaliza afirmando que perscrutar as finalidades e imperativos derivados da razão para a vida em sociedade, configurando uma nova política, a construção de fundamentos para a existência subjetiva indissociável de nossa identidade histórica e a potencialidade de uma nova estética, que venha a contemplar formas culturais plenamente humanizadas de convivência e solidariedade ética; esse é o pressuposto onde se vislumbra o sustento de uma geografia que sirva à causa da justiça, da igualdade e da liberdade.

\section{III - CONSIDERAÇÕES FINAIS}

Muitas coisas podem ser consideradas ao final dessa pesquisa. Partindo do pressuposto de uma nova proposta curricular para o ensino público do estado de São Paulo, com as reformas ocorridas desde a implementação do ideário neoliberal no mundo, a partir da década de 1980, e no Brasil, a partir da década de 1990, mudanças estruturais na educação brasileira são percebidas e contextualizadas em tal trabalho.

A educação como um todo, deveria ter práticas, conteúdos e objetivos para a construção de significados pertinentes, dentro de uma ideia de sociedade que realmente fosse articulada e estruturada para o bem comum; para a construção de uma cidadania que não encarasse a pessoa como mera mercadoria de consumo, e sim para desenvolver valores que realmente levassem, os seres humanos, para uma condição básica do "ser", e não a da condição vigente do sistema capitalista monopolizado numa condição do "ter".

Com isso, perante a abertura democrática ocorrida em nosso país, que, por uma ironia do destino, ou mesmo por uma condição histórico-social-político favorável, levou governantes com tendências conservadoras e individualistas ao poder. 
Dentro de uma lógica metodológica crítica, o trabalho mostrou as várias facetas da implementação neoliberal no país e em nosso estado, imbricado em políticas públicas para a educação importadas de países que até então eram considerados centrais no sistema capitalista mundial.

Tais políticas foram organizadas e planejadas por organismos multilaterais como o Banco Mundial, o FMI, o BIRD e o BID, juntamente com os governos ditos sociais democratas, representados pelo PSDB, principalmente no governo de Fernando Henrique Cardoso.

A cartilha neoliberal, implementada na América Latina como um todo, atribuiu todos os males sociais e econômicos a falta de gerência do Estado, em todos os âmbitos. Com isso, foi construído um discurso onde a livre iniciativa teria todas as virtudes que poderiam conduzir à regeneração e recuperação da democracia, da economia e da sociedade. Sendo assim, mostramos o quanto à educação se torna um acessório de transmissão de ideias que proclamam as excelências do livre mercado e da livre iniciativa.

Com o apelo da questão da melhoria da qualidade de ensino, de gênese neoliberal e empresarial, José Serra, governador na época, lança um plano de dez metas para a educação e a elaboração de um novo currículo para São Paulo.

Tais metas, dentro de uma política pública para a educação, foram referenciadas pela Conferência Mundial sobre Educação para Todos, ocorrida na cidade de Jomtien, na Tailândia. As discussões nesse fórum foram patrocinadas pelo Banco Mundial e UNICEF, mostrando as reais intenções para a educação paulista.

Com isso, investimentos externos foram direcionados para nosso estado, como mostramos na pesquisa.

Como subsídios de análise de tais processos, focalizando a política educacional como um todo, o estudo das teorias curriculares, assim como as práticas curriculares foram essenciais para elucidar tal processo mercantil na realidade educacional brasileira.

Afinal, são os currículos que ditam as transformações e/ou o processo de construção das pessoas, tanto perante o indivíduo como o coletivo, ressignificando a 
escola, que seguirá tal currículo. A forma como se produz esse currículo estará relacionado a pessoas que está se formando; o "como" está se formando; o porquê está se formando.

Dito isso, foi constatado que os currículos em implementação hoje em nosso país, quiçá em nosso estado, se tornaram meros instrumentos de orientação de conteúdos e práticas, voltados para uma gestão empresarial e capitalista.

Instrumentos estes que privilegiam o desenvolvimento fugaz do capital, travestido de propostas humanitárias e com apelos falsos e delirantes em relação ao desenvolvimento de um ensino e aprendizagem, que visam instrumentalizar aquilo que temos de mais precioso em nossa nação: a capacidade de apropriação e vivência de conhecimentos, que, diferentemente da ideologia capitalista, visem ações solidárias e humanísticas que possam realmente mudar os rumos de uma sociedade tão desigual quanto a nossa.

Para tanto, a análise focalizou o desenvolvimento curricular do ensino da geografia no estado de São Paulo, a luz das mudanças políticas e estruturais curriculares da nação.

Com o estabelecimento de uma nova Lei de Diretrizes e Bases da Educação, assim como os Parâmetros Curriculares Nacionais, numa época de expansão do neoliberalismo na América Latina, percebemos o quanto à geografia, através de sua renovação, impulsionada pelo processo desenfreado e desastroso da globalização, tem ganhado importância nos currículos.

E isso é perceptível na proposta curricular do estado de São Paulo. Antes subjugada como um instrumento de orientação e percepção do espaço e do território, dentro de uma lógica tradicional de ensino, descritiva e com confusões ontológicas e de afirmação como ciência; agora com uma tendência para uma transformação para uma ciência que realmente conteste e esclareça as várias facetas do desenvolvimento capitalista em expansão.

Mas as estratégias para a consolidação de uma disciplina com essa concepção não é tranquila, e sim fruto de uma luta constante. Temos muito que avançar nesse 
sentido, identificando as contradições e propondo novas ações para a consolidação de uma disciplina crítica e construtiva.

Com isso, foram levantadas questões que apontaram para um desenvolvimento da disciplina baseada e inserida no currículo do estado de São Paulo.

Pontos como as contradições metodológicas, de conteúdos e relativas aos objetivos do ensino da geografia foram levantadas, com o intuito de instigar debates e reflexões sobre os objetivos reais e coerentes para o desenvolvimento didático de uma dada realidade, dentro de um espaço-tempo determinado.

Algumas tendências da geografia universitária e escolar trabalhadas na pesquisa, trazidas pelos documentos da Proposta e dos PCNs, se destacam, como a geografia tradicional e a geografia crítica. $\mathrm{Na}$ corrente tradicional, temos uma concepção descritiva da Terra que, mesmo considerando o homem como sujeito, propunha-se, na análise da organização do espaço como lugar e território, as relações entre o homem e a natureza como processos de adaptação.

Com o intuito de superação, os debates se intensificaram no estudo epistemológico da área, trazendo uma ideia de geografia crítica que não separe o homem da natureza, e que ensine uma ciência das denúncias e lutas sociais, onde o conhecimento sirva como interesse dos alunos e não os interesses daqueles que detém o poder.

E é percebido ao longo do estudo que esse debate não foi trazido para a Proposta Curricular do estado de São Paulo. Na verdade há uma tentativa de superação da geografia tradicional, contextualizada no documento em questão, apresentada de uma forma teórica, remendada e sucinta.

Mas há deficiências. Principalmente ao que nos remete ao caráter teóricometodológico, científico e de escola. E encontramos uma concepção de geografia eclética, havendo uma confusão epistemológica sobre quais os rumos da geografia no currículo estadual.

Em nenhum momento, na análise documental, encontramos perspectivas metodológicas e de conteúdo inovadoras e plausíveis para o trabalho do professor em 
sala de aula, consolidando sua autonomia e criatividade metodológica de interagir e reagir nas diferentes situações, nas diferentes turmas, nos diferentes objetivos.

$\mathrm{Na}$ verdade, os manuais didáticos, produzidos exclusivamente para essa Proposta, seguem um rumo baseado em orientações e imposições a comunidade escolar, onde, nas circunstâncias atuais, servem como cartilhas procedimentais. É com tais materiais que se exerce um controle estatal, viabilizando as políticas educacionais e o currículo através de tais cadernos. O que realmente interessa para os propositores do currículo, é a implementação didática desses materiais no cotidiano escolar, consolidando assim o projeto educacional imposto.

$E$ isso foi entendido como um processo regulador do trabalho docente em sala de aula. E atualmente isso é observado também no plano federal.

Sendo assim, o ensino é apresentado como novo mas, na verdade, reproduz as características tradicionais de se fazer escola. Os objetivos dos conteúdos são retraduzidos para o das competências e habilidades; pois assim os PCNs quiseram.

Fechando esse ciclo curricular, temos a avaliação externa (nesse caso o SARESP) como componente fundamental para a análise de implementação de tais políticas. O controle estatal se torna mais vigoroso com tal avaliação. Mas o reflexo avaliativo geralmente não se volta para a própria escola; e sim para os detentores do poder. Há um total clima de "nada se constrói, tudo se copia"; ou mesmo "sem atividade e muita passividade".

O Currículo de Geografia na Proposta Curricular do estado de São Paulo espera a compreensão de um indivíduo competitivo, que tenha a capacidade de aprender a aprender, não sendo um indivíduo crítico dos arranjos sociais existentes, ou mesmo com ideais humanistas.

Sem dúvida, essas possíveis mudanças estão relacionadas às transformações na sociedade, principalmente a que nos remete ao mundo do trabalho flexibilizado.

O presente trabalho trouxe críticas a diversos mecanismos que são instrumentalizados pelo capital, através da política neoliberal, tais como avaliações externas às escolas, vinculada ao desempenho dos professores e alunos, tais como uma lógica empresarial. A otimização de conteúdos em detrimento da prática e dos 
objetivos mais nobres de nossa área; ou seja, a crítica a frieza e aos métodos de consolidação, maximização e acumulação do capital, sob o pretexto educacional.

Portanto existe similaridade entre a Proposta Curricular do estado de São Paulo e a concepção curricular dos organismos multilaterais.

Elucidando algumas considerações, nós esperamos que nossa pequena contribuição para tais análises sirva de subsídio para novos estudos dessas temáticas, levando a pesquisadores, geógrafos e não geógrafos, professores, assim como os leigos, a pensar e refletir que um outro mundo é possível sim; e que esse mundo não depende apenas dos outros, e sim de uma participação plena nas decisões, sejam elas curriculares ou não.

\section{III - REFERÊNCIAS BIBLIOGRÁFICAS}

ANDERSON, Perry. Balanço do Neoliberalismo. In: SADER, Emir (org.) PósNeoliberalismo: as políticas sociais e o estado democrático. São Paulo: Paz e Terra, 1995.

APEOESP. Sindicato dos professores de ensino oficial do estado de São Paulo. Proposta Curricular do estado de São Paulo: Uma análise crítica. São Paulo, 2008.

APPLE, Michael. Ideologia e currículo. São Paulo: Brasiliense, 1982.

BEZERRA NETO, Luiz, BEZERRA, Maria Cristina dos Santos e JACOMELI, Mara Regina Martins. Currículo Escolar em São Paulo - Uma proposta para discussão. In: Revista Educação e Cidadania. Vol. 8, n¹, Campinas-SP, Ed. Átomo, 2009.

BOLIGIAN, Levon. Livros didáticos e programas oficiais: contribuições para a história da cartografia no contexto da geografia escolar no Brasil. Dissertação de mestrado. Instituto de Geociências e Ciências Exatas - UNESP, 2009. 
BRANDÃO, Carlos da Fonseca. LDB passo a passo: Lei de Diretrizes e Bases da Educação Nacional (Lei $\mathrm{n}^{\circ}$ 9.394/96), comentada e interpretada, artigo por artigo. $3^{\circ}$ ed., São Paulo, Ed. Avercamp, 2007.

BRASIL. Secretaria de Educação Básica. Lei 9.394/96: Diretrizes e Bases da Educação Nacional. Brasília, MEC, 1996.

Secretaria de Educação Fundamental. Parâmetros Curriculares Nacionais: Geografia. Brasília:MEC/SEC, 1997.

Orientações Curriculares para o Ensino Fundamental: Ciências Humanas e suas Tecnologias. Vol. 3, Brasília, MEC, 2008.

. Secretaria de Educação Média e Tecnologia. Orientações Curriculares para o Ensino Médio: Ciências Humanas e suas Tecnologias. Vol. 3 Brasília, MEC, 2008.

. Parâmetros Curriculares Nacionais: ensino médio. Geografia. Brasília: MEC/SEMTEC, 2002.

PCN + Ensino Médio: orientações curriculares complementares aos Parâmetros Curriculares Nacionais - Ciências Humanas e suas Tecnologias. Brasília: MEC/SEMTEC, 2002.

CACETE, Núria Hanglei. A AGB, os PCNs e os professores. In: CARLOS, Ana Fani Alessandri \& OLIVEIRA, Ariovaldo Umbelino de. (orgs). Reformas no mundo da educação: parâmetros curriculares e geografia. São Paulo: Contexto, 1999.

, Núria Hanglei, PAGANELLI, Tomoko lyda e PONTUSCHKA, Nídia Nacib. Para ensinar e aprender geografia. São Paulo: Cortez, 2007.

CANDAU, Vera Maria, MOREIRA, Antônio Flávio Barbosa. Curículo, Conhecimento e Cultura. In: Indagações sobre Currículo. Ministério da Educação SEB. Novembro de 2006. 
CARDOSO FILHO, João P. Sociedade, educação e currículo escolar - um retrospecto. In: PUCCI, Luís F. S. e GUALTIERI, Regina C. E. O currículo na escola média: desafios e perspectivas, São Paulo, SE/CENP, 2004.

CARLOS, Ana Fani Alessandri \& OLIVEIRA, Ariovaldo Umbelino de. (orgs). Reformas no mundo da educação: parâmetros curriculares e geografia. São Paulo: Contexto, 1999.

CARLOS, Ana Fani (org.). A Geografia na sala de aula. São Paulo: Contexto, 2001

CASTELLAR, Sônia M. Vanzella. Educação geográfica: teoria e práticas docentes. São Paulo: Contexto, 2005.

CAVALCANTI, Lana de Souza. Geografia, escola e Construção de Conhecimentos. Campinas: Papirus, 2010.

CENPEC. Centro de Estudos e Pesquisas em Educação, Cultura e Ação Comunitária. Ensinar e Aprender: Reflexão e Criação - Vol. 3. São Paulo, 2004.

CICLO DE DEBATES E PALESTRAS SOBRE REFORMULAÇÃO CURRICULAR E ENSINO DA GEOGRAFIA. Anais do ciclo de debates e palestras sobre reformulação curricular e ensino da geografia. UERJ, 2002.

COLL, César. Psicologia e currículo: Uma aproximação psicopedagógica à elaboração de currículo escolar. São Paulo: Ed. Ática, 1996.

DAMIANI, Amélia L. e CARLOS, Ana F. A. Um caminho para pensar o currículo de geografia. In: CARLOS, Ana F. A. e OLIVEIRA, Ariovaldo U. In: Reformas no mundo da educação: parâmetros curriculares e geografia. São Paulo, Contexto, 1999.

ENCONTRO NACIONAL DE GEÓGRAFOS. Anais do IV Encontro Nacional de Geógrafos. Rio de Janeiro, AGB, 1980. 
ENGUITA, Mariano Fernández. O discurso da qualidade e a qualidade do discurso. In: GENTILI, Pablo A.A. \& SILVA, Tomaz Tadeu da (orgs.) neoliberalismo: qualidade total e educação. Petrópolis: Vozes, 1994.

FAZENDA, Ivani. (org.) Metodologia da Pesquisa Educacional. $3^{a}$ ed., São Paulo, Cortez, 1994.

FERREIRA, Washington Aldy. 0 currículo de geografia: uma análise do documento de reorientação curricular da SEE-RJ. Dissertação de mestrado, DG/FFLCH/USP, 2009.

FOUCHER, Michel e VESENTINI, J. W. (orgs). Geografia e ensino: textos críticos. $5^{\text {a }}$ ed., Campinas, Papirus, 2001.

FREITAS, Luiz Carlos. Políticas de Avaliação no estado de São Paulo - 0 controle do professor como ocultação do descaso. In: Revista Educação e Cidadania. Vol. 8, n¹, Campinas-SP, Ed. Átomo, 2009.

GENTILI, Pablo A.A. \& SILVA, Tomaz Tadeu da (orgs.). Neoliberalismo: qualidade total e educação. Petrópolis, RJ: Vozes, 1994.

GIMENO, J. Currículo: uma reflexão sobre a prática. Porto alegre: Artes Médicas, 1998.

GONÇALVES, Carlos Walter Porto. Reformas no mundo da educação. In: CARLOS, Ana Fani Alessandri \& OLIVEIRA, Ariovaldo Umbelino de. (orgs.). Reformas no mundo da educação: parâmetros curriculares e geografia. São Paulo: Contexto, 1999.

GOODSON, I. F. Currículo: teoria e história. Petrópolis, RJ: Vozes, 2005.

HARVEY, David. Neoliberalismo: histórias e implicações. São Paulo: Edições Loyola, 2008.

Neoliberalismo e educação: manual do usuário. In: SILVA, Tomaz Tadeu e GENTILI, P. (orgs.) Escola S.A. Brasília: CNTE, 1996. 
KOBAYASHI, Mércia Mitsuko Suzuki. Uma contribuição par o Ensino de Geografia: Estudo dos últimos Programas Curriculares de $1^{\circ}$ grau para 0 Estado de São Paulo. Dissertação de Mestrado, FFLCH/USP, 2001.

LACOSTE, Yves. A geografia: isso serve, em primeiro lugar, para fazer a guerra. $3^{\text {a }}$ ed. Campinas: Papirus, 1993.

LAKATOS, Eva Maria e MARCONI, Marina de Andrade. Metodologia Científica. São Paulo, ed. Atlas, 1983.

LEHER, Roberto. Da ideologia do desenvolvimento à ideologia da globalização: a educação como estratégia do Banco Mundial para "alívio" da pobreza. Tese de Doutorado, FE/USP, 1998.

LOPES, Alice Ribeiro Casemiro. Conhecimento escolar: ciência e cotidiano. Rio de Janeiro: Ed. UERJ, 1999.

MACEDO, Elizabeth. Disciplinas e integração curricular: histórias e políticas. In: LOPES, A. C. e MACEDO, E.(orgs) Currículo: debates contemporâneos. São Paulo, Cortez, 2002.

MACHADO, Nilson José. Sobre a ideia de competência. In: PERRENOUD, P. \& THURLER. As competências para ensinar no século XXI: A formação dos professores e o desafio da avaliação. Porto Alegre, Ed. Artmed, 2002.

MENEGOLLA, Maximiliano. Por que planejar? Como planejar? Currículo-áreaaula. $4^{\text {a }}$ ed. Petrópolis/RJ, Vozes, 1996.

MENEZES, Luís Carlos. A ciência como linguagem - prioridades no currículo do ensino médio. In: PUCCI, Luís F. S. e GUALTIERI, Regina C. E. In: O currículo na escola média: desafios e perspectivas, São Paulo, SE/CENP, 2004.

MÉSZÁROS, István. A educação para além do capital. $2^{\text {a }}$ ed., São Paulo, Boitempo, 2008. 
MORAES, Antonio Carlos R. A contribuição social do ensino de geografia. In: Anais do ciclo de debates e palestras sobre reformulação curricular e ensino da geografia. UERJ, 2002.

1. São Paulo: AGB-SP, 1982.

A Geografia Tradicional e sua renovação. Borrador $n^{\circ}$

MOREIRA, Antônio Flávio Barbosa. Currículos e Programas no Brasil. Campinas, São Paulo: Papirus, 1990.

e Sociedade. São Paulo: Cortez, 1994.

\& SILVA, Tomaz Tadeu da. Currículo, Cultura

MOREIRA, Ruy. Pensar e ser em geografia. São Paulo: Contexto, 2007.

OLIVEIRA, Ariovaldo Umbelino de (org.) Para onde vai o ensino de geografia? $9^{a}$ ed. São Paulo: Contexto, 2005.

PEREIRA, Diamantino. Geografia escolar: conteúdos e/ou objetivos? Caderno Prudentino de Geografia (17). Presidente Prudente: AGB, julho, 1995.

PEREIRA, Sandra de Castro. A Proposta Curricular do estado de São Paulo e o cotidiano escolar. In: GEOUSP - Espaço e Tempo, Edição Especial, São Paulo, pp. $71-78,2009$.

PINHEIRO, Antonio Carlos. Trajetória da pesquisa acadêmica sobre o ensino de geografia no Brasil: 1972-2000. Tese de Doutorado, IG/UNICAMP, 2003.

PLACONÁ, João. Metas e Objetivos. In: http://www.webartigos.com, 2008. Acessado em: 17/05/2011.

POLONI, Delacir Ap. R. A política educacional no Brasil e o ensino de geografia: caminhos e descaminhos. Tese de Doutorado, FFLCH/USP, 1998. 
PONTUSCHKA, Nídia N. Parâmetros curriculares nacionais: tensão entre Estado e escola. In: CARLOS, Ana F. A. e OLIVEIRA, Ariovaldo U. In: Reformas no mundo da educação: parâmetros curriculares e geografia. São Paulo, Contexto, 1999.

, PAGANELLI, Tomoko lyda e CACETE Núria Hanglei, Para ensinar e aprender geografia. São Paulo: Cortez, 2007.

PORTO, Rita de Cássia C. Avanços e recuos no currículo: o cotidiano da escola normal. Dissertação de Mestrado, PUC/SP, 1992.

REGALO, Carlos Alberto \& NUNES, Cesar. Educação Pública e Emancipação: a crise aguda do ensino de Geografia no estado de São Paulo. In: Revista Educação e Cidadania. Vol. 8, nº1, Campinas-SP, Ed. Átomo, 2009.

ROCHA, Genylton Odilon R. A política do conhecimento oficial e a nova geografia dos(as) professores(as) para as escolas brasileiras ( 0 ensino de geografia segundo os Parâmetros Curriculares Nacionais). Tese de Doutorado, FFLCH/USP, 2001

SACRAMENTO, Ana Cláudia R. O currículo na construção do conhecimento geográfico: um estudo da ação docente de duas escolas estaduais de São Paulo. Dissertação de Mestrado, FEUSP, 2007.

SAMPAIO, Maria das M. F. Um gosto amargo de escola: relações entre currículo, ensino e fracasso escolar. Dissertação de Mestrado, FEUSP, 2004.

SOARES, Maria Claro Couto. Banco Mundial: políticas e reformas. In: DE TOMMASI, Lívia, HADDAD, Sérgio \& WARDE, Miriam Jorge (orgs.) O Banco Mundial e as políticas educacionais. $2^{\mathrm{a}}$ ed. São Paulo: Cortez, 1998.

SACRISTÁN, J. Gimeno. 0 currículo: uma reflexão sobre a prática. $3^{a}$ ed. Porto Alegre: Artmed, 1998. 
SANFELICE, José Luis, MINTO, Lalo Watanabe e LOMBARDI, José Claudinei. Política e Financiamento da Educação em São Paulo. In: Revista Educação e Cidadania. Vol. 8, n¹, Campinas-SP, Ed. Átomo, 2009.

SANTOS, Milton. Por uma geografia nova: da crítica da geografia a uma geografia crítica. $3^{\mathrm{a}}$ ed. São Paulo: Hucitec, 1990.

SÃO PAULO. Caderno de Diretrizes Curriculares. Secretaria Estadual de Educação. CENP, São Paulo, 2009.

Caderno do Aluno : Geografia. $5^{\circ}$ ano, $1^{\circ}$ bimestre. Secretaria Estadual de Educação. CENP, São Paulo, 2009.

. Caderno do Aluno : Geografia. $5^{\circ}$ ano, $2^{\circ}$ bimestre. Secretaria Estadual de Educação. CENP, São Paulo, 2009.

. Caderno do Aluno : Geografia. $5^{\circ}$ ano, $3^{\circ}$ bimestre. Secretaria Estadual de Educação. CENP, São Paulo, 2009.

. Caderno do Aluno : Geografia. $5^{\circ}$ ano, $4^{\circ}$ bimestre. Secretaria Estadual de Educação. CENP, São Paulo, 2009.

. Caderno do Aluno : Geografia. $6^{\circ}$ ano, $1^{\circ}$ bimestre. Secretaria Estadual de Educação. CENP, São Paulo, 2009.

Caderno do Aluno : Geografia. $6^{\circ}$ ano, $2^{\circ}$ bimestre. Secretaria Estadual de Educação. CENP, São Paulo, 2009.

. Caderno do Aluno : Geografia. $6^{\circ}$ ano, $3^{\circ}$ bimestre. Secretaria Estadual de Educação. CENP, São Paulo, 2009.

. Caderno do Aluno : Geografia. $6^{\circ}$ ano, $4^{\circ}$ bimestre. Secretaria Estadual de Educação. CENP, São Paulo, 2009. 
CENP, São Paulo, 2009.

Caderno do Gestor : $1^{\circ}$ bimestre. Secretaria Estadual de Educação. . Caderno do Gestor : $2^{\circ}$ bimestre. Secretaria Estadual de Educação. CENP, São Paulo, 2009.

. Caderno do Gestor : $3^{\circ}$ bimestre. Secretaria Estadual de Educação. CENP, São Paulo, 2009.

. Caderno do Gestor : $4^{\circ}$ bimestre. Secretaria Estadual de Educação. CENP, São Paulo, 2009.

Caderno do Professor: Geografia. $5^{\circ}$ ano, $1^{\circ}$ bimestre. Secretaria Estadual de Educação. CENP, São Paulo, 2009.

Caderno do Professor: Geografia. $5^{\circ}$ ano, $2^{\circ}$ bimestre. Secretaria Estadual de Educação. CENP, São Paulo, 2009.

Caderno do Professor: Geografia. $5^{\circ}$ ano, $3^{\circ}$ bimestre. Secretaria Estadual de Educação. CENP, São Paulo, 2009.

. Caderno do Professor: Geografia. $5^{\circ}$ ano, $4^{\circ}$ bimestre. Secretaria Estadual de Educação. CENP, São Paulo, 2009.

. Caderno do Professor: Geografia. $6^{\circ}$ ano, $1^{\circ}$ bimestre. Secretaria Estadual de Educação. CENP, São Paulo, 2009.

Caderno do Professor: Geografia. $6^{\circ}$ ano, $2^{\circ}$ bimestre. Secretaria Estadual de Educação. CENP, São Paulo, 2009.

Caderno do Professor: Geografia. $6^{\circ}$ ano, $3^{\circ}$ bimestre. Secretaria Estadual de Educação. CENP, São Paulo, 2009. 
. Caderno do Professor: Geografia. $6^{\circ}$ ano, $4^{\circ}$ bimestre. Secretaria Estadual de Educação. CENP, São Paulo, 2009.

. Encontro de Dirigentes Regionais, Supervisores de Ensino e Diretores de Escola, COGSP, Planejamento 2008, Apresentação dos principais projetos e ações. Documento em ppt. Secretaria Estadual de Educação. São Paulo, 2008. Disponível em: http://www.saopaulofazescola.sp.gov.br.

. Matrizes de Referência de Avaliação Educacional. Documento Básico, SARESP. Secretaria Estadual de Educação. CENP. São Paulo, 2009. Disponível em: http://www.saopaulofazescola.sp.gov.br.

. Proposta curricular de história e geografia para $02^{\circ}$ grau. Secretaria Estadual de Educação. CENP. São Paulo, 1980.

Proposta curricular para o ensino de geografia. Ensino fundamental e médio. Secretaria Estadual de Educação. CENP. São Paulo, 1997.

Proposta curricular para o ensino de geografia. Ensino fundamental Il e médio. Secretaria Estadual de Educação.CENP. São Paulo, 2007.

. Proposta Pedagógica: Materiais de Suporte à Implementação. Documento em ppt. Secretaria Estadual da Educação. CENP. São Paulo, 2009. Disponível em: http://www.saopaulofazescola.sp.gov.br

. Resolução SE $n^{\circ} 76$ de 07/11/08: Implementação da proposta curricular do estado de São Paulo para o ensino fundamental e para o ensino médio das escolas estaduais. Secretaria Estadual de Educação. São Paulo, 2008.

. Resolução SE $n^{\circ} 83$ de 25/11/08: Diretrizes para organização curricular do ensino fundamental e do ensino médio das escolas estaduais. Secretaria Estadual de Educação. São Paulo, 2008.

. Resolução SE no 92 de 19/12/07: Diretrizes para organização curricular do ensino fundamental e do ensino médio das escolas estaduais. Secretaria Estadual de Educação. São Paulo, 2007. 
. Resolução SE $n^{\circ} 98$ de 23/12/08: Diretrizes para organização curricular do ensino fundamental e do ensino médio das escolas estaduais. Secretaria Estadual de Educação. São Paulo, 2008.

SARNO, Maria Cecília Mello, CANCELLIERO, José Maria. As políticas para a educação pública no Estado de São Paulo. In: Revista Educação e Cidadania. Vol. 8, nº 1, Campinas - SP, Ed. Átomo, 2009.

Saviani, Dermeval. A nova lei da educação: trajetória, limites e perspectivas. $10^{\mathrm{a}}$ ed., Campinas,SP, Autores Associados, 2006.

educacional. Campinas,SP, Autores Associados, 2007.

. Da nova LDB ao FUNDEB: por uma outra política . Formação e Condições de Trabalho Docente. In: Revista Educação e Cidadania. Vol.8, nº1, Campinas-SP, Ed. Átomo, 2009.

SAVIANI, Nereide. Políticas Curriculares - Elementos para a discussão da estrutura e organização do currículo para a rede estadual de educação de São Paulo. In: revista Educação e Sociedade. Vol. 8, nº1, Campinas-SP, Ed. Átomo, 2009.

SILVA, Jorge Luiz Barcelos da. Notas introdutórias de um itinerário interpretativo sobre a formação do pensamento brasileiro. Dissertação de Mestrado, FFLCH-USP São Paulo: 1996.

SILVA, Tomaz Tadeu da. Documentos de Identidade. $2^{\mathrm{a}}$ ed. Belo Horizonte: Autêntica, 2002.

SOUZA NETO, Manoel Fernandes de. Ágora e o agora. In: Revista Terra Livre, $\mathrm{n}^{\circ}$ 14, São Paulo, AGB, 1999. 
SOUZA, Rosa Fátima de. Política Curricular do estado de São Paulo nos anos 1980 e 1990. In: Cadernos de Pesquisa, vol. 36 no 127, São Paulo, jan. 2006. http://www.scielo.br, acessado em: 27/05/2011.

TORRES, Rosa Maria. Melhorar a qualidade da educação básica? As estratégias do Banco Mundial. In: DE TOMMASI, Lívia, HADDAD, Sérgio \& WARDE, Miriam Jorge (orgs.) O Banco Mundial e as políticas educacionais. $2^{\mathrm{a}}$ ed. São Paulo: Cortez, 1998.

VESENTINI, José William. Por uma geografia crítica na escola. São Paulo: Ática, 1992.

O novo papel da escola e do ensino da geografia na época da terceira revolução industrial. In: Revista Terra Livre, $\mathrm{n}^{\circ} 11-12$, São Paulo, AGB, 1996.

VIEIRA, Adriano. Qualidade da educação: fundamentos para promoção de políticas públicas. Dissertação de mestrado. FE-UNICAMP, 2008. 

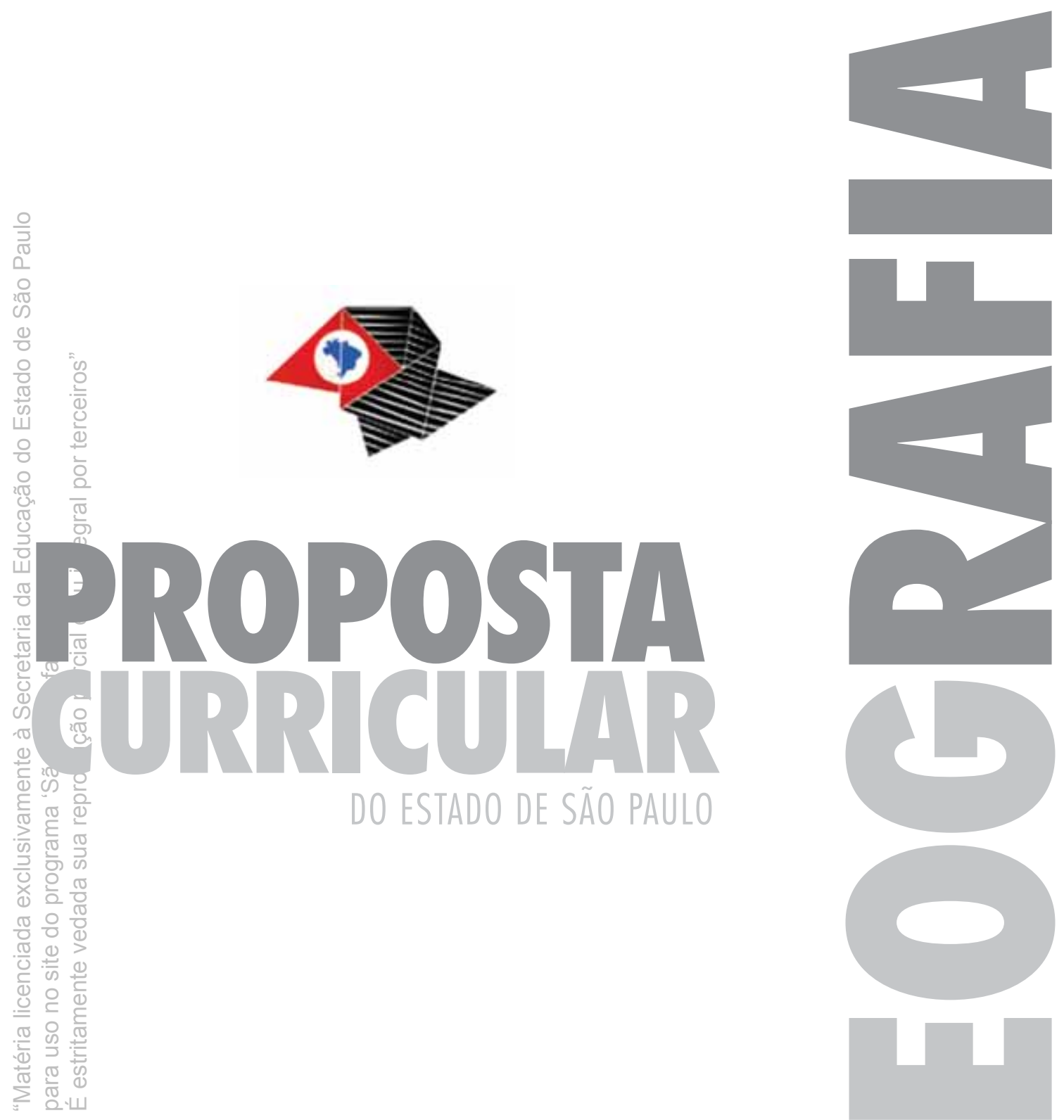

을

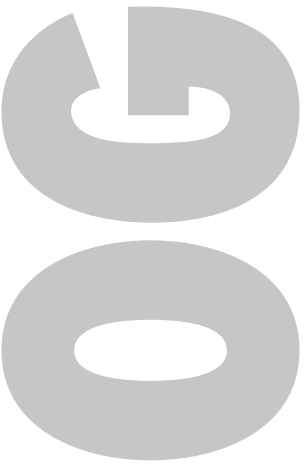

产

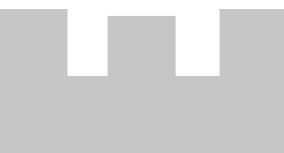

응

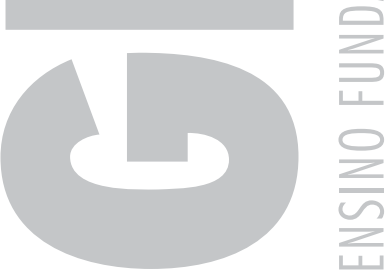




\section{a \\ GOVERNO DO ESTADO DE SÃO PAULO}

\section{Governador \\ José Serra}

Vice-Governador

Alberto Goldman

Secretária da Educação

Maria Helena Guimarães de Castro

Secretária-Adjunta

Iara Gloria Areias Prado

Chefe de Gabinete

Fernando Padula

Coordenador de Estudos e Normas Pedagógicas

José Carlos Neves Lopes

Coordenador de Ensino da Região Metropolitana da Grande São Paulo Luiz Candido Rodrigues Maria

Coordenadora de Ensino do Interior Aparecida Edna de Matos

Presidente da Fundação para o Desenvolvimento da Educação - FDE Fábio Bonini Simões de Lima

\section{EXECUÇÃO}

Coordenação Geral

Maria thês Fini

Concepção

CGuiomar Namo de Mello

Lino de Macedo

Guis Cartos de Menezes

Maria Inês Fini

Ruy-Berger

\section{$\pi$ (O)}

\section{GESTÃO}

Fundação Carlos Alberto Vanzolini

Presidente do Conselho Curador: Antonio Rafael Namur Muscat

Presidente da Diretoria Executiva: Mauro

Zilbovicius

Diretor de Gestão de Tecnologias aplicadas à

Educação: Guilherme Ary Plonsk

Coordenadoras Executivas de Projetos: Beatriz Scavazza e Angela Sprenger

\section{APOIO}

CENP - Coordenadoria de Estudos e Normas Pedagógicas

FDE - Fundação para o Desenvolvimento da Educação
Coordenação do Desenvolvimento dos Conteúdos Programáticos e dos Cadernos dos Professores

Ghisleine Trigo Silveira

\section{COORDENAÇÃO DE ÁREA PARA O} DESENVOLVIMENTO DOS CONTEÚDOS PROGRAMÁTICOS E DOS CADERNOS DOS

\section{PROFESSORES}

Ciências Humanas e suas Tecnologias: Angela Corrêa da Silva e Paulo Miceli

Ciências da Natureza e suas Tecnologias: Luis Carlos de Menezes

Linguagens, Códigos e suas Tecnologias: Alice Vieira

Matemática: Nilson José Machado

\section{AUTORES}

\section{Ciências Humanas e suas Tecnologias}

Filosofia: Adilton Luís Martins e Paulo Miceli Geografia: Angela Corrêa da Silva, Jaime Tadeu Oliva, Raul Borges Guimarães, Regina Célia Bega dos Santos, Regina Célia Corrêa de Araújo e Sérgio Adas

História: Diego López Silva, Glaydson José da Silva, Mônica Lungov Bugelli, Paulo Miceli e Raquel dos Santos Funari

\section{Ciências da Natureza e suas Tecnologias}

Biologia: Fabíola Bovo Mendonça, Ghisleine Trigo Silveira, Maria Augusta Querubim Rodrigues Pereira, Olga Aguilar Santana, Rodrigo Venturoso Mendes da Silveira e Solange Soares de Camargo Ciências: Cristina Leite, João Carlos Thomaz Micheletti Neto, Julio Cézar Foschini Lisboa, Lucilene Aparecida Esperante Limp, Maíra Batistoni e Silva, Maria Augusta Querubim Rodrigues Pereira, Maria Eunice Ribeiro Marcondes, Renata Alves Ribeiro, Rosana dos Santos Jordão, Simone Jaconetti Ydi e Yassuko Hosoume

Física: José Guilherme Brockington, Marcelo de Carvalho Bonetti, Maurício Pietrocola Pinto de Oliveira, Maxwell Roger da Purificação Siqueira e Yassuko Hosoume

Química: Fabio Luis de Souza, Hebe Ribeiro da Cruz Peixoto, Luciane Hiromi Akahoshi, Maria Eunice Ribeiro Marcondes, Maria Fernanda Penteado Lamas e Yvone Mussa Esperidião

Linguagens, Códigos e suas Tecnologias

Arte: Geraldo de Oliveira Suzigan, Gisa Picosque, Mirian Celeste Ferreira Dias Martins e Sayonara Pereira
Educação Física: Adalberto dos Santos Souza, Jocimar Daolio, Luciana Venâncio, Luiz Sanches Neto, Mauro Betti, Sérgio Roberto Silveira LEM - Inglês: Adriana Ranelli Weigel Borges, Alzira da Silva Shimoura, Lívia de Araújo Donnini Rodrigues, Priscila Mayumi Hayama e Sueli Salles Fidalgo

Língua Portuguesa: Débora Mallet Pezarin de Angelo, Eliane Aparecida de Aguiar, José Luís Marques López Landeira e João Henrique Nogueira Mateos

\section{Matemática}

Matemática: Carlos Eduardo de Souza Campos Granja, José Luiz Pastore Mello, Nilson José Machado, Rogério Ferreira da Fonseca, Ruy César Pietropaolo e Walter Spinelli

Coordenação do Desenvolvimento do Caderno do Gestor

Guiomar Namo de Mello e Marta Wolak Grosbaum

Autores: Elianeth Dias Kanthack Hernandes, Guiomar Namo de Mello, Maria Silvia Bonini Tararam, Marta Wolak Grosbaum, Miriam Martins Inácio e Terezinha Antonia Berti Tranchitella Colaboradores: Dalva de Oliveira S. da Costa, Ermelinda Maura Chezzi Dallan, José Alves da Silva, Liara Ferraz Conte APS, Maria Alice Pereira e Maura Silva Guedes

Preparação de originais: Tina Amado

Consulta à rede sobre experiências exitosas: Lourdes Athiê e Raquel B. Namo Cury

\section{EQUIPE DE PRODUÇÃO}

Coordenação Executiva: Beatriz Scavazza Assessores: Alex Barros, Beatriz Blay, Denise Blanes, Eliane Yambanis, Heloisa Amaral Dias de Oliveira, Luis Márcio Barbosa, Luiza Christov e Vanessa Dias Moretti

\section{EQUIPE EDITORIAL}

Coordenação Executiva: Angela Sprenger Projeto Editorial: Zuleika de Felice Murrie Edição e Produção Editorial: Edições Jogo de Amarelinha, Conexão Editorial e Occy Design (projeto gráfico)

\section{CTP, Impressão e Acabamento}

Imprensa Oficial do Estado de São Paulo
A Secretaria da Educação do Estado de São Paulo autoriza a reprodução deste material pelas demais secretarias de educação, desde que mantida a integridade da obra e dos créditos.

Proposta Curricular do Estado de São Paulo: Geografia /

Coord. Maria Inês Fini. - São Paulo: SEE, 2008.

ISBN 978-85-61400-07-1

1. Geografia (Ensino Fundamental e Médio) - Estudo e ensino. I. Fini, Maria Inês. II. São Paulo (Estado)

Secretaria da Educação. 

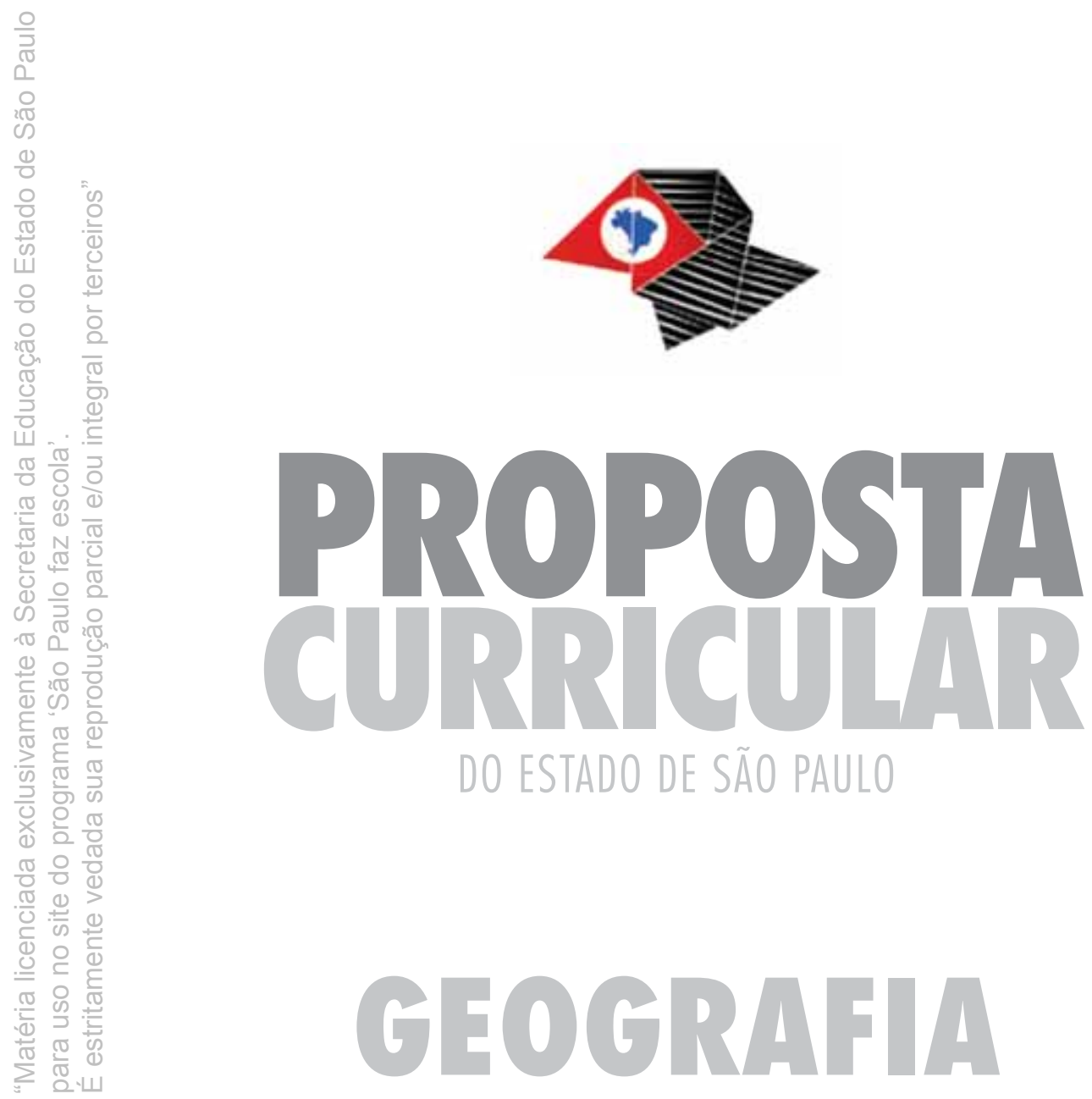

ENSINO FUNDAMENTAL - CICLO II

E ENSINO MÉDIO 


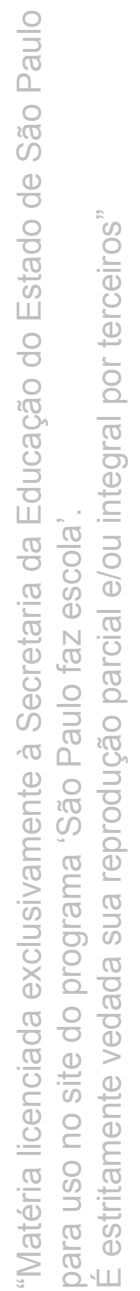




\title{
Carta da Secretária
}

\author{
Prezados gestores e professores,
}

Neste ano, colocamos em prática uma nova Proposta Curricular, para atender à necessidade de organização do ensino em todo o Estado.

A criação da Lei de Diretrizes e Bases (LDB), que deu autonomia às escolas para que definissem seus próprios projetos pedagógicos, foi um passo importante. Ao longo do tempo, porém, essa tática descentralizada mostrou-se ineficiente.

Por esse motivo, propomos agora uma ação integrada e articulada, cujo objetivo é organizar melhor o sistema educacional de São Paulo.

Com esta nova Proposta Curricular, daremos também subsídios aos profissionais que integram nossa rede para que se aprimorem cada vez mais.

Lembramos, ainda, que apesar de o currículo ter sido apresentado e discutido em toda a rede, ele está em constante evolução e aperfeiçoamento.

Mais do que simples orientação, o que propomos, com a elaboração da Proposta Curricular e de todo o material que a integra, é que nossa ação tenha um foco definido.

Apostamos na qualidade da educação. Para isso, contamos com o entusiasmo e a participação de todos.

Um grande abraço e bom trabalho.

\section{Maria Helena Guimarães de Castro}

Secretária da Educação do Estado de São Paulo 


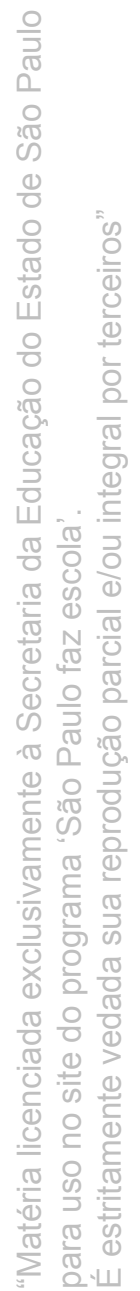




\section{Sumário}

\section{Apresentação 8}

1. Uma educação à altura dos desafios contemporâneos 9

2. Princípios para um currículo comprometido com o seu tempo

I. Uma escola que também aprende 12

II. 0 currículo como espaço de cultura 12

III. As competências como referência 13

IV. Prioridade para a competência da leitura e da escrita 16

V. Articulação das competências para aprender 18

VI. Articulação com o mundo do trabalho 20

A área de Ciências da Natureza e suas Tecnologias 26

1. A presença das Ciências da Natureza na sociedade contemporânea 26

2. A aprendizagem na área das Ciências da Natureza na educação de base 27

A Matemática e as áreas do conhecimento 32

Por que uma área específica para a Matemática? 33

A área de Linguagens, Códigos e suas Tecnologias 35

A área de Ciências Humanas e suas Tecnologias 38

Proposta Curricular do Estado de São Paulo para a disciplina de Geografia $\quad 41$ 


\section{Apresentação da Proposta Curricular do Estado de São Paulo}

A Secretaria de Educação do Estado de ¿São Paulo está realizando um projeto que visa ijpropor um currículo para os níveis de ensino Fundamental - Ciclo II e Médio. Com isso, gopretende apoiar o trabalho realizado nas es¿colas estaduais e contribuir para a melhoria da qualidade das aprendizagens de seus aluप्रnos. Esse processo partirá dos conhecimentos e das experiências práticas já acumulados, ou seja đa distematização, revisão e recuperação dé documentos, publicações e diagnósticos já existentes e do levantamento e análise dos reisutitados de projetos ou iniciativas realizados. (ब)

No intuito de fomentar o desenvolvimento curricular, a Secretaria toma assim duas Giniciativas complementares. A primeira delas é Yealizar um amplo levantamento do acervo documental e técnico pedagógico existente. A segunda é iniciar um processo de consulta a escolas e professores, para identificar, sisteImatizar e divulgar boas práticas existentes nas escolas de São Paulo. Articulando conhecimento e herança pedagógicos com experiências escolares de sucesso, a Secretaria pretende que esta iniciativa seja, mais do que uma nova declaração de intenções, o início de uma contínua produção e divulgação de subsídios que incidam diretamente na organização da escola como um todo e nas aulas. Ao iniciar este pro- cesso, a Secretaria procura também cumprir seu dever de garantir a todos uma base comum de conhecimentos e competências, para que nossas escolas funcionem de fato como uma rede. Com esse objetivo, prevê a elaboração dos subsídios indicados a seguir.

- Este documento básico apresenta os princípios orientadores para uma escola capaz de promover as competências indispensáveis ao enfrentamento dos desafios sociais, culturais e profissionais do mundo contemporâneo. O documento aborda algumas das principais características da sociedade do conhecimento e das pressões que a contemporaneidade exerce sobre os jovens cidadãos, propondo princípios orientadores para a prática educativa, a fim de que as escolas possam se tornar aptas a preparar seus alunos para esse novo tempo. Priorizando a competência de leitura e escrita, esta proposta define a escola como espaço de cultura e de articulação de competências e conteúdos disciplinares.

- Integra esta Proposta Curricular um segundo documento, de Orientações para a Gestão do Currículo na Escola, dirigido especialmente às unidades escolares e aos dirigentes e gestores que as lideram e apóiam: 
diretores, assistentes técnico-pedagógicos, professores coordenadores e supervisores. Esse segundo documento não trata da gestão curricular em geral, mas tem a finalidade específica de apoiar o gestor para que seja um líder e animador da implementação desta Proposta Curricular nas escolas públicas estaduais de São Paulo.

- Existe uma variedade de outros programas e materiais disponíveis sobre o tema da gestão, alguns dos quais descritos em ane$x \bar{Q}$, aos quais as equipes gestoras também poderão recorrer para apoiar seu trabalho. Oj ponto mais importante desse segundo documento é garantir que o Projeto Pedagógico, que organiza o trabalho nas condiçõos singulares de cada escola, seja um reccurso efetivo e dinâmico para assegurar aos alunos a aprendizagem dos conteúdos e constituição das competências previstas nesta Proposta Curricular. O segundo documento, Orientações para a Gestão do Currículo, propõe que a aprendizagem resulte tâmbém da coordenação de ações entre as disciplinas, do estímulo à vida cultural da escola e do fortalecimento de suas relações com a comunidade. Para isso, reforça e propõe orientações e estratégias para a educação continuada dos professores.

- A Proposta Curricular se completará com um conjunto de documentos dirigidos especialmente aos professores.
São os Cadernos do Professor, organizados por bimestre e por disciplina. Neles, são apresentadas situações de aprendizagem para orientar o trabalho do professor no ensino dos conteúdos disciplinares específicos. Esses conteúdos, habilidades e competências são organizados por série e acompanhados de orientações para a gestão da sala de aula, para a avaliação e a recuperação, bem como de sugestões de métodos e estratégias de trabalho nas aulas, experimentações, projetos coletivos, atividades extraclasse e estudos interdisciplinares.

\section{Uma educação à altura dos desafios contemporâneos}

A sociedade do século XXI é cada vez mais caracterizada pelo uso intensivo do conhecimento, seja para trabalhar, conviver ou exercer a cidadania, seja para cuidar do ambiente em que se vive. Essa sociedade, produto da revolução tecnológica que se acelerou na segunda metade do século passado e dos processos políticos que redesenharam as relações mundiais, já está gerando um novo tipo de desigualdade, ou exclusão, ligada ao uso das tecnologias de comunicação que hoje mediam o acesso ao conhecimento e aos bens culturais. Na sociedade de hoje, são indesejáveis tanto a exclusão pela falta de acesso a bens materiais quanto a exclusão pela falta de acesso ao conhecimento e aos bens culturais. 
No Brasil essa tendência caminha paralelamente à democratização do acesso a níveis educacionais além do ensino obrigatório. Com mais gente estudando, a posse de um diploma de nível superior deixa de ser um diferencial suficiente, e características cognitivas e afetivas são cada vez mais ivalorizadas, como as capacidades de resolGer problemas, trabalhar em grupo, contiG्रuap aprendendo e agir de modo cooperativo, pertinente em situações complexas. Em um mundo no qual o conhecimento ¿é usado de forma intensiva, o diferencial serámarcado pela qualidade da educação recebida. A qualidade do convívio, assim como dos conhecimentos e das competêncías constituídas na vida escolar, será o fator determinante para a participação do iñdivíduo em seu próprio grupo social e gara que tome parte de processos de críticà eurenovação.

Nesse quadro ganha importância redobrada a qualidade da educação oferecida nas escolas públicas, pois é para elas que estão acorrendo, em número cada vez Tmais expressivo, as camadas mais pobres da sociedade brasileira, que antes não tinham acesso à escola. A relevância e a pertinência das aprendizagens escolares nessas instituições são decisivas para que o acesso a elas proporcione uma oportunidade real de aprendizagem para inserção no mundo de modo produtivo e solidário.
Outro fenômeno relevante diz respeito à precocidade da adolescência, ao mesmo tempo em que o ingresso no trabalho se torna cada vez mais tardio. Tais fenômenos ampliam o tempo e a importância da permanência na escola, tornando-a um lugar privilegiado para o desenvolvimento do pensamento autônomo, que é condição para uma cidadania responsável. Ser estudante, nesse mundo que expõe o jovem desde muito cedo às práticas da vida adulta - e, ao mesmo tempo, posterga a sua inserção profissional -, é fazer da experiência escolar uma oportunidade para aprender a ser livre e ao mesmo tempo respeitar as diferenças e as regras de convivência. Hoje, mais do que nunca, aprender na escola é o "ofício de aluno", a partir do qual ele vai fazer o trânsito para a autonomia da vida adulta e profissional.

Para que a democratização do acesso à educação tenha uma função realmente inclusiva não é suficiente universalizar a escola. É indispensável a universalização da relevância da aprendizagem. Criamos uma civilização que reduz distâncias, que tem instrumentos capazes de aproximar as pessoas ou de distanciá-las, que aumenta o acesso à informação e ao conhecimento, mas que também acentua diferenças culturais, sociais e econômicas. Só uma educação de qualidade para todos pode evitar que essas diferenças constituam mais um fator de exclusão. 
O desenvolvimento pessoal é um processo de aprimoramento das capacidades de agir, pensar, atuar sobre o mundo e lidar com a influência do mundo sobre cada um, bem como atribuir significados e ser percedbido e significado pelos outros, apreender a diversidade e ser compreendido por ela, isituar-se e pertencer. A educação precisa estar a serviço desse desenvolvimento, que coincieide com a construção da identidade, da autonomia e da liberdade. Não há liberdade sem possibilidade de escolhas. Elas gopressupõem um quadro de referências, um Jepertório que só pode ser garantido se chöuver acesso a um amplo conhecimento, dảdô por uma educação geral, articuladora, que transite entre o local e o mundial. Esseotipo de educação constrói, de forma cooperativa e solidária, uma síntese dos sáberes produzidos pela humanidade, ao Jongo de sua história e de sua geografia, e dos saberes locais. Tal síntese é uma das condições para o individúo acessar o coInfhecimento necessário ao exercício da cidadẩnia em dimensão mundial.

A autonomia para gerenciar a própria aprendizagem (aprender a aprender) e o resultado dela em intervenções solidárias (aprender a fazer e a conviver) deve ser a base da educação das crianças, dos jovens e dos adultos, que têm em suas mãos a continuidade da produção cultural e das práticas sociais.
Construir identidade, agir com autonomia e em relação com o outro, e incorporar a diversidade são as bases para a construção de valores de pertencimento e responsabilidade, essenciais para a inserção cidadã nas dimensões sociais e produtivas. Preparar indivíduos para manter o equilíbrio da produção cultural, num tempo em que a duração se caracteriza não pela permanência, mas pela constante mudança - quando o inusitado, o incerto e o urgente constituem a regra e não a exceção -, é mais um desafio contemporâneo para a educação escolar.

Outro elemento relevante hoje para pensarmos o conteúdo e o sentido da escola é a complexidade da ambiência cultural, das dimensões sociais, econômicas e políticas, a presença maciça de produtos científicos e tecnológicos e a multiplicidade de linguagens e códigos no cotidiano. Apropriar-se ou não desses conhecimentos pode ser um instrumento da ampliação das liberdades ou mais um fator de exclusão.

O currículo que dá conteúdo e sentido à escola precisa levar em conta esses elementos. Por isso, esta Proposta Curricular tem como princípios centrais: a escola que aprende, o currículo como espaço de cultura, as competências como eixo de aprendizagem, a prioridade da competência de leitura e de escrita, a articulação das competências para aprender e a contextualização no mundo do trabalho. 


\section{Princípios para um currículo comprometido com o seu tempo}

\section{Uma escola que também aprende}

A tecnologia imprime um ritmo sem ¡precedentes no acúmulo de conhecimentos e gera uma transformação profunda na sua estrutura e nas suas formas de organização e Codistrị̂buição. Nesse contexto, a capacidade de laprender terá de ser trabalhada não apenas nos alunos, mas na própria escola, enquanto instituição educativa: tanto as instituições como os docentes terão de aprender.

Isso muda radicalmente nossa concepç̧ão da escola como instituição que ensina ipara posicioná-la como instituição que também aprende a ensinar. As interações entre os responsáveis pela aprendizagem dos alünos têm caráter de ações formadoras, mesmo que os envolvidos não se dêem conta disso. Neste sentido, cabe lembrar a responsábilidade da equipe gestora como formadoya de professores e a responsabilidade dos dôcentes, entre si e com o grupo gestor, na Toproblematização e na significação dos conhecimentos sobre sua prática.

De acordo com essa concepção, a escola que aprende parte do princípio de que ninguém conhece tudo e de que o conhecimento coletivo é maior que a soma dos conhecimentos individuais, além de ser qualitativamente diferente. Esse é o ponto de partida para o trabalho colaborativo, para a formação de uma "comunidade aprendente", nova terminologia para um dos mais antigos ideais educativos. A vantagem é que hoje a tecnologia facilita a viabilização prática desse ideal.

Ações como a construção coletiva da Proposta Pedagógica, por meio da reflexão e da prática compartilhadas, e o uso intencional da convivência como situação de aprendizagem fazem parte da constituição de uma escola à altura dos tempos atuais. Observar que as regras da boa pedagogia também se aplicam àqueles que estão aprendendo a ensinar é uma das chaves para o sucesso das lideranças escolares. Os gestores, como agentes formadores, devem aplicar com os professores tudo aquilo que recomendam a eles que apliquem com seus alunos.

\section{O currículo como espaço de cultura}

No cotidiano escolar, a cultura é muitas vezes associada ao que é local, pitoresco, folclórico, bem como ao divertimento ou lazer, enquanto o conhecimento é freqüentemente associado a um inalcançável saber. Essa dicotomia não cabe em nossos tempos: a informação está disponível a qualquer instante, em tempo real, ao toque de um dedo, e o conhecimento constitui-se como uma ferramenta para articular teoria e prática, o mundial e o local, o abstrato e seu contexto físico. 
Currículo é a expressão de tudo o que existe na cultura científica, artística e humanista, transposto para uma situação de aprendizagem e ensino. Precisamos entender que as atividades extraclasse não são "extracurriculares" quando se deseja articular a cultura e o conhecimento. Neste sentido todas as atividades da escola são curriculares, ou não Serão justificáveis no contexto escolar. Se não Gompermos essa dissociação entre cultura e conkecimento não conseguiremos conectar o currículo à vida - e seguiremos alojando ¿na escola uma miríade de atividades "culturais" que mais dispersam e confundem do qüe promovem aprendizagens curriculares Trelevantes para os alunos.

O conhecimento tomado como instrumento, mobilizado em competências, greforça o sentido cultural da aprendizagem. Tomádo como valor de conteúdo lúdico, de caráter ético ou de fruição estética, numa escolacom vida cultural ativa, o conhecimento torna-se um prazer que pode ser aprendido, ao se aprender a aprender. Nessa escola, o ఫprofessor não se limita a suprir o aluno de saberes, mas é o parceiro de fazeres culturais, aquele que promove de muitas formas o desejo de aprender, sobretudo com o exemplo de seu próprio entusiasmo pela cultura humanista, científica, artística e literária.

Quando o projeto pedagógico da escola tem entre suas prioridades essa cidadania cul- tural, o currículo é a referência para ampliar, localizar e contextualizar os conhecimentos que a humanidade acumulou ao longo do tempo. Então, o fato de uma informação ou um conhecimento ser de outro lugar, ou de todos os lugares na grande rede de informação, não será obstáculo à prática cultural resultante da mobilização desse conhecimento nas ciências, nas artes e nas humanidades.

\section{As competências como referência}

Um currículo que promove competências tem o compromisso de articular as disciplinas e as atividades escolares com aquilo que se espera que os alunos aprendam ao longo dos anos. Logo, a atuação do professor, os conteúdos, as metodologias disciplinares e a aprendizagem requerida dos alunos são aspectos indissociáveis: compõem um sistema ou rede cujas partes têm características e funções específicas que se complementam para formar um todo, sempre maior do que elas. Maior porque se compromete em formar crianças e jovens para que se tornem adultos preparados para exercer suas responsabilidades (trabalho, família, autonomia etc.) e para atuar em uma sociedade que muito precisa deles.

Um currículo referido a competências supõe que se aceite o desafio de promover os conhecimentos próprios de cada disciplina articuladamente às competências e habilidades do aluno. É com essas competências e habi- 
lidades que ele contará para fazer sua leitura crítica do mundo, para compreendê-lo e propor explicações, para defender suas idéias e compartilhar novas e melhores formas de ser, na complexidade em que hoje isso é requerido. É com elas que, em síntese, ele poderá Eenfrentar problemas e agir de modo coerente em favor das múltiplas possibilidades de soluçãa ou gestão.

Tais competências e habilidades podem ser consideradas em uma perspectiva geral, jsto é, no que têm de comum com as disciplinas e tarefas escolares, ou então no que têm dè específico. Competências, neste sentido, caracterizam modos de ser, raciocinar e interagir que podem ser depreendidos das ações das tomadas de decisão em contextos de problemas, tarefas ou atividades. Graças a elas podemos inferir se a escola como instituifção está cumprindo bem o papel que se espera dela no mundo de hoje.

Os alunos considerados nesta proyostà têm, de modo geral, de 11 a 18 anos dé idade. Valorizar o desenvolvimento de competências nesta fase da vida implica em ponderar, além de aspectos curriculares e docentes, os recursos cognitivos, afetivos e sociais de que os alunos dispõem. Implica, pois, em analisar como o professor mobiliza conteúdos, metodologias e saberes próprios de sua disciplina ou área de conhecimento, visando desenvolver com- petências em adolescentes, bem como instigar desdobramentos para a vida adulta.

Paralelamente a essa conduta, é preciso considerar quem são esses alunos. Ter entre 11 e 18 anos significa estar em uma fase peculiar da vida, localizada entre a infância e a idade adulta. Neste sentido, o jovem é aquele que deixou de ser criança e se prepara para tornarse adulto. Trata-se de um momento complexo e contraditório, que deve orientar nossa proposta sobre o papel da escola nessa fase de vida.

Nessa etapa curricular, a tríade sobre a qual competências e habilidades são desenvolvidas pode ser assim caracterizada: a) o adolescente e as características de suas ações e pensamentos; b) o professor, suas características pessoais e profissionais e a qualidade de suas mediações; e c) os conteúdos das disciplinas e as metodologias para seu ensino e aprendizagem.

Houve um tempo em que a educação escolar era referenciada no ensino - o plano de trabalho da escola indicava o que seria ensinado ao aluno. Essa foi uma das razões pelas quais o currículo escolar foi confundido com um rol de conteúdos disciplinares. A Lei de Diretrizes e Bases - LDB (lei 9394/1996) deslocou o foco do ensino para o da aprendizagem, e não é por acaso que sua filosofia não é mais a da liberdade de ensino, mas a do direito de aprender. 
O conceito de competências também é fundamental na LDB e nas Diretrizes e Parâmetros Curriculares Nacionais, elaboradas pelo Conselho Nacional de Educação e pelo Ministério da Educação. O currículo referenciado em competências é uma concepção que requer que a escola e o plano do profes¿sor indiquem o que aluno vai aprender.

Uma das razões para se optar por uma educação centrada em competências diz respeito à democratização da escola. No ymomento em que se conclui o processo de Juniversalização do Ensino Fundamental e se gincorpora toda a heterogeneidade que caTracteriza o povo brasileiro, a escola, para ser democrática, tem de ser igualmente acessível a todos, diversa no tratamento de cada um e cunitária nos resultados.

Dificilmente essa unidade seria obtida comênfase no ensino, porque é quase impossivel, em um país como o Brasil, estabelecer o que deve ser ensinado a todos, sem exceção. Por isso optou-se por construir a uninidade com ênfase no que é indispensável que todos tenham aprendido ao final do processo, considerando a diversidade. Todos têm direito de construir, ao longo de sua escolaridade, um conjunto básico de competências, definido pela lei. Este é o direito básico, mas a escola deverá ser tão diversa quanto são os pontos de partida das crianças que recebe. Assim, será possível garantir igualdade de oportunidades, diversidade de tratamento e unidade de resultados. Quando os pontos de partida são diferentes, é preciso tratar diferentemente os desiguais para garantir a todos uma base comum.

Pensar o currículo no tempo atual é viver uma transição, na qual, como em toda transição, traços do velho e do novo se mesclam nas práticas cotidianas. É comum que o professor, quando formula o seu plano de trabalho, indique o que vai ensinar e não o que o aluno vai aprender. E é compreensível nesse caso que, ao final do ano, tendo cumprido seu plano, ele afirme, diante do fracasso do aluno, que fez sua parte, ensinando, e que foi o aluno que não aprendeu.

A transição da cultura do ensino para a da aprendizagem não é individual. A escola deve fazê-la coletivamente, tendo à frente seus gestores para capacitar os professores em seu dia-a-dia, a fim de que todos se apropriem dessa mudança de foco. Cabe às instâncias condutoras da política educacional nos estados e nos municípios elaborar, a partir das Diretrizes e dos Parâmetros Nacionais, Propostas Curriculares próprias e específicas, prover os recursos humanos, técnicos e didáticos para que as escolas, em seu projeto pedagógico, estabeleçam os planos de trabalho que, por sua vez, farão das propostas currículos em ação - como no presente esforço desta Secretaria. 


\section{Prioridade para a competência da leitura e da escrita}

A humanidade criou a palavra, que é constitutiva do humano, seu traço distintivo. O ser humano constitui-se assim um ser de linguagem e disso decorre todo o restante, tudo o que transformou a humainidade naquilo que é. Ao associar palavras e sinais, criando a escrita, o homem construiu um instrumental que ampliou expoinencialmente sua capacidade de comunicar-se, incluindo pessoas que estão longe no tempo e no espaço.

Representar, comunicar e expressar são atividades de construção de significado relaciōnădas a vivências que se incorporam ao repertório de saberes de cada indivíduo. Os sentidos são construídos na relação entre a glinguagem e o universo natural e cultural em que nos situamos. E é na adolescência, como vimos, que a linguagem adquire essa qualidade de instrumento para compreender e agir sobre o mundo real.

A ampliação das capacidades de reTpresentação, comunicação e expressão está articulada ao domínio não apenas da língua mas de todas as outras linguagens e, principalmente, ao repertório cultural de cada indivíduo e de seu grupo social, que a elas dá sentido. A escola é o espaço em que ocorre a transmissão, entre as gerações, do ativo cultural da humanidade, seja artístico e li- terário, histórico e social, seja científico e tecnológico. Em cada uma dessas áreas, as linguagens são essenciais.

As linguagens são sistemas simbólicos, com os quais recortamos e representamos o que está em nosso exterior, em nosso interior e na relação entre esses âmbitos; é com eles também que nos comunicamos com os nossos iguais e expressamos nossa articulação com o mundo.

Em nossa sociedade, as linguagens e os códigos se multiplicam: os meios de comunicação estão repletos de gráficos, esquemas, diagramas, infográficos, fotografias e desenhos. O design diferencia produtos equivalentes quanto ao desempenho ou à qualidade. A publicidade circunda nossas vidas, exigindo permanentes tomadas de decisão e fazendo uso de linguagens sedutoras e até enigmáticas. Códigos sonoros e visuais estabelecem a comunicação nos diferentes espaços. As ciências construíram suas próprias linguagens, plenas de símbolos e códigos. A produção de bens e serviços foi em grande parte automatizada e cabe a nós programar as máquinas, utilizando linguagens específicas. As manifestações artísticas e de entretenimento utilizam, cada vez mais, diversas linguagens que se articulam.

Para acompanhar tal contexto, a competência de leitura e de escrita contemplada 
nesta proposta vai além da linguagem verbal, vernácula - ainda que esta tenha papel fundamental - e refere-se a sistemas simbólicos como os citados, pois essas múltiplas linguagens estão presentes no mundo contemporâneo, na vida cultural e política, bem como nas designações e nos conceitos cienitíficos e tecnológicos usados atualmente. A constituição dessa competência tem como Goase o desenvolvimento do pensamento antecipatório, combinatório e probabilístico que permite estabelecer hipóteses, algo que caracteriza o período da adolescência.

A prioridade das linguagens no currículo da educação básica tem como fundamento a centralidade da linguagem no desenvolvimento da criança e do adolescente. Nas crianças a linguagem, em suas diversas expressões, é apenas um recurso simbólico, Ou seja, permite representar ou comunicar conteúdos cujas formas, elas mesmas, não podem ser estruturadas como linguagem. Nessa fase, tais formas são as próprias ações e os pensamentos, organizados como esquemas de procedimentos, representações e compreensões. Ou seja, as crianças realizam e compreendem ao falar, pensar ou sentir, mas não sabem ainda tratar o próprio agir, pensar ou sentir como uma forma de linguagem. É só na adolescência que isso se tornará possível e transformará o ser humano em um ser de linguagem, em sua expressão mais radical.
A linguagem não é apenas uma forma de representação, como expressam, por seus limites, as crianças. Mais do que isso, ela é uma forma de compreensão e ação sobre o mundo. É isso o que os adolescentes, com todos os seus exageros, manifestam. Graças à linguagem, o pensamento pode se tornar antecipatório em sua manifestação mais completa: é possível calcular as conseqüências de uma ação sem precisar realizá-la. Pode-se ainda fazer combinações e analisar hipóteses sem precisar conferi-las de antemão, na prática, pois algumas de suas conseqüências podem ser deduzidas apenas pelo âmbito da linguagem. Pode-se estabelecer relações de relações, isto é, imaginar um objeto e agir sobre ele, decidindo se vale a pena ou não interagir com ele em outro plano. Em outras palavras, graças à linguagem, agora constituída como forma de pensar e agir, o adolescente pode raciocinar em um contexto de proposições ou possibilidades, pode ter um pensamento combinatório, pode aprender as disciplinas escolares em sua versão mais exigente, pode refletir sobre os valores e fundamentos das coisas.

Do ponto de vista social e afetivo, a centralidade da linguagem nos processos de desenvolvimento possibilita ao adolescente aprender, pouco a pouco, a considerar suas escolhas em uma escala de valores. ViabilizaIhe aprender a enfrentar as conseqüências das próprias ações, a propor e alterar contratos, a respeitar e criticar normas, a formular 
seu próprio projeto de vida e a tecer seus sonhos de transformação do mundo.

É, portanto, em virtude da centralidade da linguagem no desenvolvimento da criança ce do adolescente que esta Proposta Curricular prioriza a competência leitora e escritora. SSó por meio dela será possível concretizar a constituição das demais competências, tanto âs gerais como aquelas associadas a discipliinas ou temas específicos. Para desenvolvê-la é indispensável que seja objetivo de aprendizagem de todas as disciplinas do currículo, ao Jongo de toda a escolaridade básica.

Por esse caráter essencial da competência de leitura e escrita para a aprendizagem dós conteúdos curriculares de todas as áreas e disciplinas, a responsabilidade por sua aprendizagem e avaliação cabe a todos os professores, que devem transformar seu trabalho em oportunidades nas quais os alunos possam aprender e consolidar o uso da Língua Portuguesa e das outras linguagens e códigos que fazem parte da cultura, bem como das formas de comunicação em cada uma delas. Tal radicalismo na centralidade da competência leitora e escritora leva a colocá-la como objetivo de todas as séries e todas as disciplinas. Desta forma, coloca aos gestores (a quem cabe a educação continuada dos professores na escola) a necessidade de criar oportunidades para que os docentes também desenvolvam essa competência - por cuja constituição, nos alunos, são responsáveis.
Por fim, é importante destacar que o domínio das linguagens representa um primordial elemento para a conquista da autonomia, sendo a chave para o acesso a informações e permitindo a comunicação de idéias, a expressão de sentimentos e o diálogo, necessários à negociação dos significados e à aprendizagem continuada.

\section{Articulação das competências para aprender}

A aprendizagem é o centro da atividade escolar. Por extensão, o professor caracteriza-se como um profissional da aprendizagem e não tanto do ensino. Isto é, ele apresenta e explica conteúdos, organiza situações para a aprendizagem de conceitos, métodos, formas de agir e pensar, em suma, promove conhecimentos que possam ser mobilizados em competências e habilidades, as quais, por sua vez, instrumentalizam os alunos para enfrentar os problemas do mundo real. Dessa forma, a expressão "educar para a vida" pode ganhar seu sentido mais nobre e verdadeiro na prática do ensino. Se a educação básica é para a vida, a quantidade e a qualidade do conhecimento têm de ser determinadas por sua relevância para a vida de hoje e do futuro, além dos limites da escola. Portanto, mais que os conteúdos isolados, as competências são guias eficazes para educar para a vida. As competências são mais gerais e constantes, e os conteúdos, mais específicos e variáveis. É exatamente a possibilidade 
de variar os conteúdos no tempo e no espaço que legitima a iniciativa dos diferentes sistemas públicos de ensino para selecionar, organizar e ordenar os saberes disciplinares que servirão como base para a constituição de competências, cuja referência são as diretrizes e orientações nacionais, de um lado, e as demandas do imundo contemporâneo, de outro.

As novas tecnologias da informação produziram uma mudança na produção, na organização, no acesso e na disseminação do ¿conhecimento. A escola hoje já não é mais a zúnicâ detentora da informação e do conhecimento, mas cabe a ela preparar seu aluno Tara viver em uma sociedade em que a informaçẵo é disseminada em grande velocidade. (1) 응

Vale insistir que essa preparação não exige maior quantidade de ensino e sim meThor qualidade de aprendizagem. É preciso deixar claro que isso não significa que os conteúdos do ensino não sejam importantes; ao contrário, são tão importantes que a eles está dedicado este trabalho de elaboração da Proposta Curricular do ensino oficial do Estado de São Paulo. São tão decisivos que é indispensável aprender a continuar aprendendo os conteúdos escolares, mesmo fora da escola ou depois dela. Continuar aprendendo é a mais vital das competências que a educação deste século precisa desenvolver. Não só os conhecimentos com os quais a escola trabaIha podem mudar, como a vida de cada um trará novas ênfases e necessidades, que precisarão ser continuamente supridas. Preparar-se para acompanhar esse movimento torna-se o grande desafio das novas gerações.

Esta Proposta Curricular adota, como competências para aprender, aquelas que foram formuladas no referencial teórico do Enem - Exame Nacional do Ensino Médio. Entendidas como desdobramentos da competência leitora e escritora, para cada uma das cinco competências do Enem transcritas a seguir, apresenta-se a articulação com a competência de ler e escrever.

I. "Dominar a norma culta da Língua Portuguesa e fazer uso das linguagens matemática, artística e científica." A constituição da competência de leitura e escrita é também o domínio das normas e dos códigos que tornam as linguagens instrumentos eficientes de registro e expressão, que podem ser compartilhados. Ler e escrever, hoje, são competências fundamentais a qualquer disciplina ou profissão. Ler, entre outras coisas, é interpretar (atribuir sentido ou significado), e escrever, igualmente, é assumir uma autoria individual ou coletiva (tornar-se responsável por uma ação e suas conseqüências).

II. "Construir e aplicar conceitos das várias áreas do conhecimento para a compreensão de fenômenos naturais, de processos históricogeográficos, da produção tecnológica e das 
manifestações artísticas." É o desenvolvimento da linguagem que possibilita o raciocínio hipotético-dedutivo, indispensável à compreensão de fenômenos. Ler, nesse sentido, é um modo de compreender, isto é, de assimilar experiências ou conteúdos disciplinares (e modos de sua produção); escrever é expressar sua construção ou reconstrução com sentido, aluno por aluno.

III. "Selecionar, organizar, relacionar, interpretar dados e informações representados de differentes formas, para tomar decisões e enfrentar situações-problema". Ler implica também - além de empregar o raciocínio hipotético-dedutivo, que possibilita a compreensão de fenômenos - antecipar, de forma comprometida, a ação para intervir no fenômeno e resolver os problemas decorrentes dele. Escrever, por sua vez, significa dominar os muitos formatos que a solução do problema comporta.

IV "Relacionar informações, representadas em diferentes formas, e conhecimentos disponíveis em situações concretas, para construir argumentação consistente." A leitura, aqui, sintetiza a capacidade de escutar, supor, informar-se, relacionar, comparar etc. A escrita permite dominar os códigos que expressam a defesa ou a reconstrução de argumentos - com liberdade, mas observando regras e assumindo responsabilidades.
V. "Recorrer aos conhecimentos desenvolvidos na escola para elaborar propostas de intervenção solidária na realidade, respeitando os valores humanos e considerando a diversidade sociocultural." Ler, aqui, além de implicar em descrever e compreender, bem como em argumentar a respeito de um fenômeno, requer a antecipação de uma intervenção sobre ele, com tomada de decisões a partir de uma escala de valores. Escrever é formular um plano para essa intervenção, levantar hipóteses sobre os meios mais eficientes para garantir resultados, a partir da escala de valores adotada. É no contexto da realização de projetos escolares que os alunos aprendem a criticar, respeitar e propor projetos valiosos para toda a sociedade; por intermédio deles, aprendem a ler e escrever as coisas do mundo atual, relacionando ações locais com visão global, por meio de atuação solidária.

\section{Articulação com o mundo do trabalho}

A contextualização tem como norte os dispositivos da Lei de Diretrizes e Bases, as normas das Diretrizes Curriculares Nacionais, que são obrigatórias, e as recomendações dos Parâmetros Curriculares Nacionais, que foram elaborados para o Ensino Médio mas são pertinentes para a educação básica como um todo, sobretudo para o segmento da $5^{a}$ série em diante. Para isso é preciso recuperar alguns tópicos desse conjunto legal e normativo. 


\section{Compreensão do significado das ciências, das letras e das artes}

Compreender o sentido é reconhecer, apreender e partilhar a cultura que envolve as áreas de conhecimento, um conjunto de conceitos, posturas, condutas, valores, enfoques, estilos de trabalho e modos de fazer que caGracterizam as várias ciências - exatas, sociais e humanas -, as artes - visuais, musicais, do OMmovimento e outras -, a Matemática, as línguas e outras áreas de expressão não-verbal.

Quando a LDB dispõe sobre esse objetivo de compreensão do sentido está indicando qựe ñão se trata de formar especialistas nem profissionais. Especialistas e profissionais devem além de compreender o sentido, domicnar a estrutura conceitual e o estatuto epistemolốgico de suas especialidades - não é esse - caso dos alunos da educação básica. Como estão na escola, preparando-se para assumir plenamente sua cidadania, todos devem passar pela alfabetização científica, humanista, dingưistica, artística e técnica, para que sua cidad̄ania, além de ser um direito, tenha quaGidade. O aluno precisa constituir as competêncías para reconhecer, identificar e ter visão crítica daquilo que é próprio de uma área de conhecimento, e, a partir desse conhecimento, avaliar a importância dessa área ou disciplina em sua vida e em seu trabalho.

A lei dá um prazo generoso para que os alunos aprendam o "significado das ciências, das artes e das letras": começa na educação infantil, prossegue nos anos do Ensino Fundamental e tem mais três anos no Ensino Médio. Durante mais de doze anos deverá haver tempo suficiente para alfabetizar-se nas ciências, nas humanidades e nas técnicas, entendendo seus enfoques e métodos mais importantes, seus pontos fortes e fracos, suas polêmicas, seus conceitos e, sobretudo, o modo como suas descobertas influenciam a vida das pessoas e o desenvolvimento social e econômico. Para isso, é importante abordar, em cada ano ou nível da escola básica, a maneira como as diferentes áreas do currículo articulam a realidade e seus objetos de conhecimento específicos, a partir de questões como as exemplificadas a seguir.

- Que limitações e potenciais têm os enfoques próprios das áreas?

- Que práticas humanas, das mais simples às mais complexas, têm fundamento ou inspiração nessa ciência, arte ou área de conhecimento?

- Quais as grandes polêmicas nas várias disciplinas ou áreas de conhecimento?

\section{A relação entre teoria e prática em cada disciplina do currículo}

A relação entre teoria e prática não envolve necessariamente algo observável ou manipulável, como um experimento de 
laboratório ou a construção de um objeto. Tal relação pode acontecer ao se compreender como a teoria se aplica em contextos reais ou simulados. Uma possibilidade de transposição didática é reproduzir a indagação de origem, a questão ou necessidade que levou à Construção de um conhecimento - que já está dado e precisa ser apropriado e aplicado, não obrigatoriamente ser "descoberto" de novo.

A lei determina corretamente que a relação teoria e prática se dê em cada disciplina do currículo, uma vez que boa parte dos aproblemas de qualidade do ensino decorre da dificuldade em destacar a dimensão prática do conhecimento, tornando-o verbalista e abstrato. Por exemplo, a disciplina História é por vezes considerada teórica, mas nada é tão prático quanto entender a origem de uma cidade ¿as razões da configuração urbana. A Química é érroneamente considerada mais prática por envolver atividades de laboratório, manipulação de substâncias e outras idiossincrasias, no entanto não existe nada mais teórico do que o estudo da tabela de elementos químicos.

A mesma Química que emprega o nome dos elementos precisa ser um instrumento cognitivo para nos ajudar a entender e, se preciso, decidir pelo uso de alimentos com agrotóxicos ou conservantes. Tais questões não se restringem a especialistas ou cientistas. Não é preciso ser químico para ter de escolher o que se vai comer. A fim de sermos cidadãos plenos, devemos adquirir discernimento e conhecimentos pertinentes para tomar decisões em diversos momentos, em relação à escolha de alimentos, uso da eletricidade, consumo de água, seleção dos programas de TV ou a escolha do candidato a um cargo político.

\section{As relações entre educação e tecnologia}

A educação tecnológica básica é uma das diretrizes que a LDB estabelece para orientar o currículo do Ensino Médio. A lei ainda associa a "compreensão dos fundamentos científicos dos processos produtivos" com o relacionamento entre teoria e prática em cada disciplina do currículo. E insiste quando detaIha, entre as competências que o aluno deve demonstrar ao final da educação básica, o "domínio dos princípios científicos e tecnológicos que presidem a produção moderna".

A tecnologia comparece, portanto, no currículo da educação básica com duas acepções complementares: a) como educação tecnológica básica; b) como compreensão dos fundamentos científicos e tecnológicos da produção.

A primeira acepção refere-se à alfabetização tecnológica, que inclui aprender a lidar com computadores, mas vai além. Alfabetizarse tecnologicamente é entender as tecnologias da história humana como elementos da cultura, como parte das práticas sociais, culturais e 
produtivas, que por sua vez são inseparáveis dos conhecimentos científicos, artísticos e lingüísticos que as fundamentam. A educação tecnológica básica tem o sentido de nos preparar para viver e conviver em um mundo no qual a tecnologia está cada vez mais presente: no qual a tarja magnética, o celular, o código de barras e muitos recursos digitais se incorporam velozmente à vida das pessoas, qualquer que seja a sua condição socioeconômica.

A segunda acepção, ou seja, a compreensão dos fundamentos científicos e tecnológicos da produção, faz da tecnologia a chave para relacionar o currículo ao mundo đá produção de bens e serviços, ou seja, aos processos pelos quais a humanidade - e cada um de nós - produz os bens e serviços de que necessita para viver. Foi para manter-se fiel ao espírito da lei que as DCN introduziram a tecnologia em todas as áreas, tanto das DCN como dos PCN para o Ensino Médio, evitando ra existência de disciplinas "tecnológicas" isoladas e separadas dos conhecimentos que lhe servem de fundamento.

\section{A prioridade para o contexto do trabalho}

Se examinarmos o conjunto das recomendações já analisadas, o trabalho enquanto produção de bens e serviços revela-se como a prática humana mais importante para conectar os conteúdos do currículo com a realidade.
Desde sua abertura, a LDB faz referência ao trabalho, juntamente com as práticas sociais, como elemento que vincula a educação básica à realidade, da Educação Infantil até o final do Ensino Médio. O vínculo com o trabalho carrega vários sentidos, que é preciso explicitar.

Do ponto de vista filosófico, expressa o valor e a importância do trabalho. À parte de qualquer implicação pedagógica relativa a currículos e definição de conteúdos, o valor do trabalho incide em toda a vida escolar: desde a valorização dos trabalhadores da escola e da família, até o respeito aos trabalhadores da comunidade, o conhecimento do trabalho como produtor da riqueza e o reconhecimento de que um dos fundamentos da desigualdade social é a remuneração injusta do trabalho. A valorização do trabalho é também uma crítica ao bacharelismo ilustrado, que por muito tempo predominou nas escolas voltadas para as classes sociais privilegiadas.

A implicação pedagógica desse princípio atribui um lugar de destaque para o trabalho humano, contextualizando os conteúdos curriculares sempre que for pertinente, com os tratamentos adequados a cada caso. Nesse sentido, a relação entre teoria e prática em cada disciplina do currículo, como exige a lei, não pode deixar de incluir os tipos de trabalho e as carreiras profissionais aos quais se aplicam os conhecimentos das áreas ou disciplinas curriculares. 
Em síntese, a prioridade do trabalho na educação básica assume dois sentidos complementares: como valor, que imprime importância ao trabalho e cultiva o respeito que lhe é devido na sociedade, e como tema que perpassa os conteúdos curriculares, atribuindo sentido aos conhecimentos específicos das disciplinas.

\section{O contexto do trabalho no Ensino Médio}

A tradição de ensino academicista, desvinculado de qualquer preocupação com a prática, separou a formação geral e a formaçã̃o profissional no Brasil. Durante décadas elas foram modalidades excludentes de ensinô. A tentativa da Lei 5692/1971 de unir as düas modalidades, profissionalizando todo o Ensiño Médio, apenas descaracterizou a forImação geral, sem ganhos significativos para a profissional.

Nos dias de hoje, essa separação já não se dá nos mesmos moldes, porque o mundo do trabalho passa por transformaÇổes profundas. À medida que a tecnologia vai substituindo os trabalhadores por autômatos na linha de montagem e nas tarefas de rotina, as competências para trabalhar em ilhas de produção, associar concepção e execução, resolver problemas e tomar decisões tornam-se mais importantes do que conhecimentos e habilidades voltados para postos específicos de trabalho.
A LDB adota uma perspectiva sintonizada com essas mudanças na organização do trabalho ao recomendar a articulação entre educação básica e profissional, quando afirma, entre as finalidades do Ensino Médio: "a preparação básica para o trabaIho e a cidadania do educando, para continuar aprendendo, de modo a ser capaz de se adaptar com flexibilidade a novas condições de ocupação ou aperfeiçoamento posteriores" (grifo nosso). A lei não recupera a formação profissional para postos ou áreas específicas dentro da carga horária geral do Ensino Médio, como tentou fazer a legislação anterior. Mas também não chancela o caráter inteiramente propedêutico que esse ensino tem assumido na educação básica brasileira. Trata-se, portanto, de entender o que vem a ser a preparação básica para o trabalho.

As Diretrizes Curriculares Nacionais para o Ensino Médio interpretaram essa perspectiva como uma preparação básica para o trabalho, abrindo a possibilidade de que os sistemas de ensino ou as escolas tenham ênfases curriculares diferentes, com autonomia para eleger as disciplinas específicas e suas respectivas cargas horárias dentro das três grandes áreas instituídas pelas DCN, desde que garantida a presença das três áreas. Essa abertura permite que escolas de Ensino Médio, a partir de um projeto pedagógico integrado com cursos de edu- 
cação profissional de nível técnico, atribuam mais tempo e atenção a disciplinas ou áreas disciplinares cujo estudo possa ser aproveitado na educação profissional.

Para as DCN, o que a lei denomina de preparação básica para o trabalho pode ser ra aprendizagem de conteúdos disciplinares constituintes de competências básicas que ড్çejam também pré-requisitos de formação profissional. Em muitos casos essa opção pouparia tempo de estudo para o jovem que uprecisa ingressar precocemente no mercado de trabalho. Para facilitar essa abertura, as Diretrizes Curriculares da Educação Profissional de Nivel Técnico flexibilizaram a duração dos cursôs profissionais desse nível, possibilitanudo óaproveitamento de estudos já realizados ou mesmo exercício profissional prévio. Essas duas peças normativas criaram os mecanismos pedagógicos que podem viabilizar o que foi estabelecido na LDB (lei 9394/1996) e decretos posteriores.

A preparação básica para o trabalho em determinada área profissional, portanto, pode ser realizada em disciplinas de formação básica do Ensino Médio. As escolas, nesse caso, atribuiriam carga horária suficiente e tratamento pedagógico adequado às áreas ou disciplinas que melhor preparassem seus alunos para o curso de educação profissional de nível técnico escolhido. Essa possibilidade fundamenta-se no pressuposto de que ênfases curriculares diferenciadas são equivalentes para a constituição das competências previstas na LDB, nas DCN para o Ensino Médio e na matriz de competências do Enem.

Isso supõe um outro tipo de articulação entre currículos de formação geral e currículos de formação profissional, em que o primeiro encarrega-se das competências básicas, fundamentando a constituição das mesmas em conteúdos, áreas ou disciplinas afinadas com a formação profissional nesse ou em outro nível de escolarização. E supõe também que o tratamento oferecido às disciplinas do currículo do Ensino Médio não seja apenas propedêutico nem tampouco voltado estreitamente para o vestibular. 


\section{A área de Ciências da Natureza e suas Tecnologias}

\section{A presença das Ciências da Natureza na sociedade contemporânea}

As Ciências da Natureza estão presentes sob muitas formas na cultura e na vida em 'socièdade, na investigação dos materiais, das substâncias, da vida e do cosmo. Do mesmo gumodo, elas se associam às técnicas, tomando aparte em todos os setores de produção e de sérviços: da agropecuária à medicina, da in"dû́stríia ao sistema financeiro, dos transportes à comunicação e informação, dos armamentòs bélicos aos aparelhos domésticos. Essa associação entre as ciências e as técnicas, que constitui a tecnologia, resultou nas váJiăs revoluções industriais e integra todas as dimensões práticas da vida humana, como ra extração e processamento de minérios, a ¿produção de energia, a construção civil, a pro¿dưção de alimentos, o envio de mensagens e o diấgnóstico de enfermidades.

O desenvolvimento científico-tecnológico tem sido tão rápido que certos processos e equipamentos podem tornar-se obsoletos em poucos anos. Essa corrida pela inovação transforma até mesmo algumas práticas sociais, como está acontecendo com a rápida expansão da telefonia móvel e da rede mundial de computadores. Por sua vez, as ciências também se beneficiam do desenvolvimento tecnológico nas suas investigações, como no lançamento em órbita terrestre de um grande telescópio, ou na tomada e no processamento de dados científicos feitos em laboratórios, por equipamentos informáticos.

As Ciências da Natureza também têm dimensão filosófica, pois, ao interpretar eventos da biosfera e compreender a evolução da vida, ou ao observar estrelas e galáxias e perceber a evolução do universo, elas permitem conjecturar sobre a origem e o sentido cósmicos - atividades que no passado eram prerrogativa do pensamento filosófico. Em contrapartida, para monitorar ou controlar o desenvolvimento científicotecnológico, ao investigar a intervenção humana na biosfera e eventualmente estabelecer seus limites, os instrumentos para essa investigação de sentido igualmente ético são também científico-tecnológicos. As ciências são, portanto, base conceitual para intervenções práticas que podem ser destrutivas - como na tecnologia bélica -, mas também promovem valores humanos ao fornecerem critérios para a percepção crítica e para a interpretação da realidade. 
Finalmente, as ciências têm grande beleza, por ampliar a visão do mundo natural, ao mergulhar nos detalhes moleculares da base genética da vida ou ao revelar a periodicidade de caráter quântico das propriedades dos elementos químicos. O mesmo se dá em sua estética da simplicidade, em que umas poucas Ieis gerais valem para qualquer processo, como o princípio da conservação da energia que se aaplica ao vôo de um colibri ou à emissão de luz por úm átomo. Essa beleza das ciências, ainda que menos reconhecida, pode ser comparada đà das artes, no sentido mesmo de fruição, preCisamente pela associação da ciência ao sentide pragmático das tecnologias.

Essa múltipla presença, a intensa produçã̃o e a divulgação de conhecimentos científicos e techológicos demanda de todos nós uma alfábetização científico-tecnológica. Por exemplo: para saber que uma água mineral de pH 4,5 é acida; para ler medidas de energia em quilowatt-hora, caloria, joule, e converter uma unidadde na outra; ou para entender argumentos a favor̂ e contra a produção de grãos transgênicos demănda-se um domínio conceitual científico básicico, mesmo em se tratando de informações usuais presentes em jornais diários, equipamentos domésticos e embalagens de alimentos.

Por isso tudo, jovens que concluem a educação de base, preparados para seu desenvolvimento e sua realização pessoal, devem saber se expressar e se comunicar com as lin- guagens da ciência e fazer uso de seus conhecimentos. Dessa forma, poderão compreender e se posicionar diante de questões gerais de sentido científico e tecnológico, e empreender ações diante de problemas pessoais ou sociais para os quais o domínio das ciências seja essencial, como será detalhado a seguir.

\section{A aprendizagem na área das Ciências da Natureza na educação de base}

Mais do que simples divisões do saber, as disciplinas em geral são campos de investigação e de sistematização dos conhecimentos. Algumas delas são milenares, como a Filosofia, a História e a Física. Outras, como a Matemática, reúnem campos igualmente antigos, como a Geometria e a Álgebra. Outras ainda, como a Biologia, são reuniões recentes de campos tradicionais, como a Botânica, a Zoologia e a História Natural, aos quais se somaram outros, mais contemporâneos, como a Genética.

Nem sempre se estabelecem fronteiras nítidas entre as disciplinas. A Química, que surgiu há alguns séculos, apresenta interesses comuns com a Física, como a constituição atômica da matéria, e outros em comum com a Biologia, como processos bioquímicos e o estudo das substâncias orgânicas. Todas as Ciências da Natureza fazem uso de instrumentais matemáticos em seus procedimentos de quantificação, análise e modelagem. 
A reunião de certos conjuntos de disciplinas em áreas do conhecimento é decorrência natural das referidas fronteiras comuns. No nosso caso, é também um recurso de sentido pedagógico, para explicitar que a aprendizagem disciplinar não tem sentido autônomo, mas deve se dar em função dos interesses dos alunos, de Sua formação geral. Nesse sentido, a área Constitui uma pré-articulação de um sisteima mais amplo, o projeto pedagógico de escola, em que a proposta curricular orgaưniza e dá razões para a aprendizagem em geral, disciplinar ou não.

O conjunto das Ciências da Natureza póde ser tomado como uma das áreas do conhecimento que organizam a aprendizagemna educação básica, pois, ainda que diferentes ciências, como a Biologia, a Física e a Química tenham certos objetos de estudo e métodos próprios, também têm em comum conceitos, métodos e procedimentos, critérios de análise, de experimentação e de verificação. Além disso, elas compõem uma visão de mundo coerente, um acervo cultural articulado e reúnem linguagens essenciais, recursos e valores que se complementam para uma atuação prática e crítica na vida contemporânea. Com essa compreensão, vê-se que a articulação numa área permite compreender melhor o papel educacional da Biologia, da Física ou da Química, do que tomar cada disciplina isoladamente.
Não se deve, assim, estranhar que da $5^{a}$ à $8^{a}$ série do Ensino Fundamental as ciências estejam integradas na mesma disciplina escolar, englobando também as linguagens adequadas para cada faixa etária. $\mathrm{Na} 5^{\mathrm{a}} \mathrm{e}$ na $6^{a}$ série, a ênfase está colocada na realidade mais imediata do aluno, com suas vivências e percepções pessoais, e também como tema para exercício do letramento propriamente dito e para o início da alfabetização científico-tecnológica.

$\mathrm{Na} 7^{\mathrm{a}}$ e na $8^{\mathrm{a}}$ série, a ênfase já se desloca para temáticas mais abrangentes e suas interpretações. Por isso, o corpo humano e seus sistemas, o ser humano como partícipe da biosfera, as tecnologias de uso cotidiano ou as primeiras percepções cósmicas da Terra no Universo devem ter tratamentos compatíveis com a maturidade em cada fase.

Ao fim do Ensino Fundamental, já é possível identificar e qualificar as muitas tecnologias presentes na produção industrial e energética, agropecuária e extrativa, nas comunicações, no processamento de informações, nos serviços de saúde, nos bens de consumo, no monitoramento ambiental etc. Praticamente em todos os setores da vida em sociedade, dando-se o mesmo foco às questões globais, como a dos combustíveis fósseis e dos renováveis, a defesa da biodiversidade ou o comprometimento dos mananciais de água. 
Já no Ensino Médio, é possível ousar um maior aprofundamento conceitual da área de conhecimento nas três disciplinas científicas básicas - Biologia, Física e Química - , nas quais a especificidade temática e metodológica se explicita, permitindo, inclusive, uma ־organização curricular mais detalhada. Por exemplo, na constituição celular ou na interdependência das espécies, em Biologia; nas condâs eletromagnéticas ou na relação trabaITho-calor, na Física; e na dinâmica das reações ou hos compostos orgânicos, na Química, guntamente com as tecnologias às quais estão diretamente relacionados todos esses aspectos disciplinares. Esse maior aprofundamento dả disciplina não deve significar qualquer exagero propedêutico, o que pode ser evitado qüando se explicitam competências relacionadas ào conhecimento científico e aos contextos reais, geralmente interdisciplinares.

Voltando a pensar o projeto pedagógico escolar, a área do conhecimento de "Ciências da Natureza tem importante interface com a área das Ciências Humanas; por exemplo, os períodos históricos são pautados pelos conhecimentos técnicos e científicos presentes nas atividades econômicas, assim como as trocas comerciais, as disputas internacionais e os domínios territoriais dependem do desenvolvimento das forças produtivas, estreitamente associadas aos conhecimentos científicos. Também alguns campos de investigação científica, como os da cosmologia e da evolução, como vimos, têm forte apelo e interesse filosófico.

Da mesma forma, há uma ampla interface com a área das linguagens e códigos, pois as Ciências da Natureza, de um lado, fazem uso de inúmeras linguagens e, de outro, constituem linguagens elas próprias. Hoje, não é sequer possível compreender muitas notícias sem que se entendam terminologias científicas como "materiais semicondutores", "substâncias alcalinas" e "grãos transgênicos". Essa dimensão das ciências como linguagem precisa, assim, ser explicitada e trabalhada na sua aprendizagem escolar, pois constituirá a qualificação mais continuamente exercida pelos educandos ao longo de sua vida, qualquer que seja sua opção profissional e cultural.

Enfim, a sociedade atual, diante de questões como a busca de modernização produtiva, cuidados com o ambiente natural, procura de novas fontes energéticas, escolha de padrões para as telecomunicações, precisa lançar mão das ciências como provedoras de linguagens, instrumentos e critérios. Por isso, a educação de base que se conclui no Ensino Médio deve promover conhecimento científico e tecnológico para ser apreendido e dominado pelos cidadãos como recurso seu, não "dos outros" sejam cientistas ou engenheiros, e utilizado como recurso de expressão, instrumento de julgamento, tomada de posição ou resolução de problemas em contextos reais. 
Essas expectativas de aprendizagem estão expressas na nossa Lei de Diretrizes e Bases da Educação (LDB), de 1996, em termos de grandes campos de competência, como o domínio "das formas contemsporâneas de linguagem" ou "dos princí¡pios científico-tecnológicos que presidem a produção moderna". Para atender a tal orientação, o ensino das Ciências da Natureza deve buscar compor o desenvolvimento da cultura científica com a promoção de competências mais gerais ou de habilidades mais específicas como as expressas no quadro seguinte:

\section{Competências} gerais

\section{Habilidades gerais e específicas}

- Representar.

- Comunicar-se.

- Conviver.

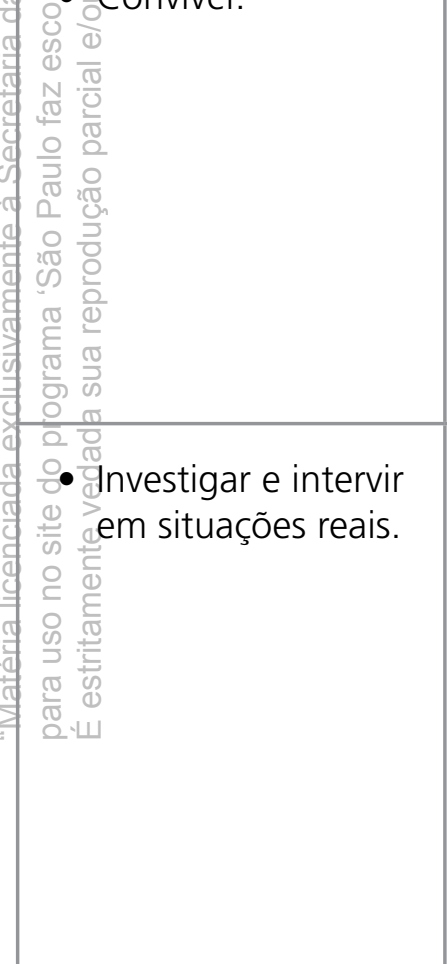

- Ler e expressar-se com textos, cifras, ícones, gráficos, tabelas e fórmulas.

- Converter uma linguagem em outra.
- Registrar medidas e observações.

- Descrever situações.

- Planejar e fazer entrevistas.
- Sistematizar dados.

- Elaborar relatórios.

- Participar de reuniões.

- Argumentar.

- Trabalhar em grupo.

- Formular questões.

- Realizar observações.

- Selecionar variáveis.

- Estabelecer relações.
- Interpretar, propor e fazer experimentos.

- Fazer e verificar hipóteses.
- Diagnosticar e enfrentar problemas, individualmente ou em equipe. 


\begin{tabular}{|c|c|c|c|}
\hline $\begin{array}{c}\text { Competências } \\
\text { gerais }\end{array}$ & \multicolumn{3}{|c|}{ Habilidades gerais e específicas } \\
\hline $\begin{array}{l}\text { - Estabelecer } \\
\text { conexões e dar } \\
\text { contexto. }\end{array}$ & $\begin{array}{l}\text { - Relacionar } \\
\text { informações e } \\
\text { processos com } \\
\text { seus contextos } \\
\text { e com diversas } \\
\text { áreas de } \\
\text { conhecimento. }\end{array}$ & $\begin{array}{l}\text { - Identificar } \\
\text { dimensões } \\
\text { sociais, éticas } \\
\text { e estéticas } \\
\text { em questões } \\
\text { técnicas e } \\
\text { científicas. }\end{array}$ & $\begin{array}{l}\text { - Analisar o papel } \\
\text { da ciência e } \\
\text { da tecnologia } \\
\text { no presente e } \\
\text { ao longo da } \\
\text { História }\end{array}$ \\
\hline $\begin{array}{l}\text { Enfim, deve assegu } \\
\text { das Ciências da Natu } \\
\text { ttìr, na preparação do }\end{array}$ & $\begin{array}{l}\text { m tipo de ensi- } \\
\text { de forma a ga- } \\
\text { /ens no Ensino }\end{array}$ & \multicolumn{2}{|c|}{$\begin{array}{l}\text { Médio, uma efetiva apropriação das ciências } \\
\text { como qualificação pessoal, não simplesmen- } \\
\text { te como ilustração cultural. }\end{array}$} \\
\hline
\end{tabular}




\section{A Matemática e as áreas do conhecimento}

Em todas as épocas e em todas as culturas, a Matemática e a língua materna constituem dois componentes básicos dos currículos escolares. Tal fato era traduzido, em tempos antigos, pela caracterização da função tríplice da escola, como o lugar em qquese aprenderia a "ler, escrever e contar" I- o que significava, sinteticamente, uma duTpla "alfabetização": no universo das letras ¿e no dos números. Naturalmente, há muito a "alfabetização" que se espera da escola teve sua ação ampliada para incorporar o Ginteresse pelas múltiplas linguagens presentes na sociedade contemporânea, que use estendem para os universos das ciências e das tecnologias, particularmente no que se refere às tecnologias informáticas.

Em decorrência de tais fatos, em organizações curriculares mais recentes, como nos Parâmetros Curriculares Naciounais (PCN), um mapeamento do conhecimento a ser apresentado - de maneira tanto disciplinada quanto disciplinar - na escola, surgiram propostas de organização dos conteúdos em três grandes áreas:

- Linguagens, incluindo-se as línguas estrangeiras, a Educação Física e as Artes, como diferentes formas de expressão;
- Ciências Humanas, incluindo-se História, Geografia e, no caso do Ensino Médio, Filosofia;

- Ciências Naturais e Matemática, uma grande área que no Ensino Médio inclui as disciplinas de Física, Química, Biologia e Matemática.

Sempre houve discussões acaloradas sobre a possibilidade de a Matemática ser incluída na área de Linguagens, o que faria sentido, sem dúvida. Afinal, juntamente com a Língua Materna, a Matemática compõe o par de sistemas simbólicos fundamentais para a representação da realidade, para a expressão de si e compreensão do outro, para a leitura, em sentido amplo, de textos e do mundo dos fenômenos.

Entretanto, na organização final dos documentos que integram os $\mathrm{PCN}$, prevaleceu a proximidade com as Ciências $\mathrm{Na-}$ turais. Isso também faz sentido, pois estas encontram na Matemática uma linguagem especialmente apropriada, desde as origens da Ciência moderna, com Galileu, até Descartes, com seu sonho de expressão de todo conhecimento confiável na linguagem matemática. 
No Estado de São Paulo, nas propostas curriculares elaboradas a partir de 1986 e em vigor até o presente momento, a Matemática era apresentada como uma área específica. Tais propostas constituíram um esforço expressivo, e em alguns sentidos pioneiro, na busca de uma aproximação entre os conteúdos escolares e o universo da cultura, especialmente ho que tange às contextualizações e à busca Co de ưna instrumentação crítica para o mundo do trabalho. Essa rica herança pedagógica sobreviveu a uma avalanche de novidades passageiras e serve agora de ponto de partida para que, incorporadas as necessárias atualizações, novos passos sejam dados para sua efetivação Thas práticas escolares. Particularmente no que tange às áreas em que se organiza, a nova uproposta inspirou-se na anterior, mantendo a área de Matemática como um terreno específico, distinto tanto das Linguagens quanto das Eiências Naturais.

\section{Porque uma área específica} para a Matemática?

Três são as razões principais desta opção. Em primeiro lugar, destaca-se o fato de que uma parte da especificidade da Matemática resulta esmaecida quando ela é agregada seja ao grupo das linguagens em sentido amplo, ou seja, ao grupo das ciências. A Matemática compõe com a Língua Materna um par fundamental, mas de caráter complementar: é impossível reduzir um dos sistemas simbólicos ao outro. Se uma língua se aproximar demasiadamente do modo de operar da Matemática, resultará empobrecida, e o mesmo poderia ocorrer com um texto matemático que assumisse a ambivalência, apropriada apenas à expressão lingüística. A multiplicidade de sentidos em um mesmo elemento simbólico ou combinação de elementos é própria da língua natural e é intencionalmente controlada na expressão matemática. A busca da expressão precisa é inerente na Matemática, mas pode empobrecer o uso natural da língua. Não que esta não possa ser precisa: ela o é exemplarmente, como bem revela um texto poético, em que uma palavra não pode ser substituída por um sinônimo sem desmontar o poema. Mas existe uma diferença fundamental, irredutível, entre a precisão na Língua e a precisão na Matemática.

Em segundo lugar, a incorporação da Matemática à área de Ciências pode distorcer o fato de que a Matemática, mesmo oferecendo uma linguagem especialmente importante e adequada para a expressão científica, constitui um conhecimento específico da educação básica. Tal conhecimento inclui um universo próprio muito rico de objetos, instrumentos e interesses, fundamentais tanto para as chamadas Ciências Naturais quanto para as Ciências Humanas, e ainda para as Linguagens em sentido amplo. A inclusão da Matemática na área de 
Ciências teve o efeito salutar, no caso dos PCN, de minimizar o risco de que o conteúdo matemático fosse concebido como um fim em si mesmo, enfatizando sua condição instrumental. Entretanto, a partir da consodidação da idéia de competências, apresentada pelo Exame Nacional do Ensino Médio (Enem), tal risco deixou de existir e explicitase com nitidez o que já era apresentado tacitamente em propostas anteriores: todos os cônteúdos disciplinares, nas diversas áreas, são meios para a formação dos alunos como cidadãos e como pessoas. As discioplinàs são imprescindíveis e fundamentais, más $=$ foco permanente da ação educacioThal deve situar-se no desenvolvimento das competências pessoais dos alunos.

\section{i $\frac{\circ}{5} \div$}

Em terceiro lugar, o tratamento da Matemática como área específica pode facilitar a İnçorporação crítica dos inúmeros recursos tecnológicos de que dispomos para a representaç̧ão de dados e o tratamento das informações, na busca da transformação de informação em conhecimento. De fato, caso se pretendesse caracterizar um novo Trivium (grupo de disciplinas constituído por Lógica, Gramática e Retórica), mais consentâneo com as características da sociedade contemporânea, certamente pareceria mais justo incluir a Língua, a Matemática e a Informática. E, ainda que os computadores sejam hoje instrumentos absolutamente imprescindíveis para jornalistas e escritores em geral, é no terreno da Matemática que se abrem as mais naturais e promissoras possibilidades de assimilação dos inúmeros recursos que as tecnologias informáticas podem oferecer no terreno da Educação.

Insistimos, no entanto, no fato de que a apresentação da Matemática como uma área específica não pretende amplificar suas supostas peculiaridades nem caracterizá-la como um tema excessivamente especializado ou relevante. Visa apenas a uma exploração mais adequada de suas possibilidades de servir às outras áreas, na ingente tarefa de transformar a informação em conhecimento em sentido amplo, em todas as suas formas de manifestação. 


\section{A área de Linguagens, Códigos e suas Tecnologias}

A área de Linguagens, Códigos e suas Tecnologias compreende um conjunto de dis¿ciplinas: Língua Portuguesa, Língua Estrangeiira Moderna (LEM), Arte e Educação Física, no Ensino Fundamental e no Médio. Para a área, ¿ șegưndo os Parâmetros Curriculares NacioInais (PCN 2006), a linguagem é a capacidade humana de articular significados coletivos em ¿्sistemas arbitrários de representação, que são compartilhados e que variam de acordo com ras necessidades e experiências da vida em socièdầde. A principal razão de qualquer ato de gingựagem é a produção de sentido.

\section{is $\frac{O}{\bar{D}}$}

Mais do que objetos de conhecimento, aś linguagens são meios para o conhecimento. O homem conhece o mundo através de suas linguagens, de seus símbolos. À medida que ele se torna mais competente nas diferentes linguagens, torna-se mais capaz de coinhecer a si mesmo, assim como a sua cultura e 0 mundo em que vive.

Nesta perspectiva, trabalha-se, em primeiro lugar, com a construção do conhecimento: conhecimento lingüístico, musical, corporal; conhecimento gestual; conhecimento das imagens, do espaço e das formas. Assim, propõe-se uma mudança profunda na maneira como as disciplinas da área devem ser examinadas e ensinadas. O conhecimento de natureza enciclopédica, sem significação prática, é substituído por conteúdos e atividades que possibilitam não só a interação do aluno com sua sociedade e o meio ambiente, mas também o aumento do seu poder como cidadão, propiciando maior acesso às informações e melhores possibilidades de interpretação das informações nos contextos sociais em que são apresentadas.

Com tal mudança, a experiência escolar transforma-se em uma vivência que permite ao aluno compreender as diferentes linguagens e usá-las como meios de organização da realidade, nelas constituindo significados, em um processo centrado nas dimensões comunicativas da expressão, da informação e da argumentação. Esse processo exige que o aluno analise, interprete e utilize os recursos expressivos da linguagem, relacionando textos com seus contextos, confrontando opiniões e pontos de vista e respeitando as diferentes manifestações da linguagem utilizada por diversos grupos sociais, em suas esfera de socialização.

Utilizar-se da linguagem é saber colocarse como protagonista do processo de produção/ recepção. É também entender os princípios das tecnologias da comunicação e da informação, associando-os aos conhecimentos científicos e às outras linguagens, que lhes dão suporte. 
O ser humano é um ser de linguagens, as quais são tanto meios de produção da cultura quanto parte fundamental da cultura humana. Por cultura entendemos a urdidura de muitos fios que se interligam constantemente e que respondem às diferentes formas com que nos relacionamos com as coisas de inosso mundo, com os outros seres humanos e com os objetos e as práticas materiais de nossa vida. Cultura é, assim, uma trama tecida por um longo processo acumulativo que reflete conhecimentos originados da प्रrelação dos indivíduos com as diferentes coisas do mundo.

Somos herdeiros de um longo processo acumulativo que constantemente se amplia e renova sem anular a sua história, refletindo, dessa forma, o conhecimento e a experiên¿́a adquiridos pelas gerações anteriores. É a mannipulação adequada e criativa desse patriưôninio cultural que possibilita as inovações e as invenções humanas e o contínuo caminhar da sociedade.

Como manifestações culturais, a Literatưra e a Arte não devem ser reduzidas a meras listagens de escolas, autores e suas características. O ensino de Arte não pode equivaler nem ao conhecimento histórico nem à mera aquisição de repertório, e muito menos a um fazer por fazer, espontaneísta, desvinculado da reflexão e do tratamento da informação. No ensino das diversas linguagens artísticas, não se pode mais abandonar quer o eixo da produção (eixo poético), quer o da recepção (eixo estético), quer o da crítica.

Da mesma maneira, a Educação Física compreende o sujeito mergulhado em diferentes realidades culturais, nas quais estão indissociados corpo, movimento e intencionalidade. Ela não se reduz mais ao condicionamento físico e ao esporte, quando praticados de maneira inconsciente ou mecânica. O aluno do Ensino Fundamental e do Médio deve não só vivenciar, experimentar, valorizar, apreciar e aproveitar os benefícios advindos da cultura do movimento, mas também perceber e compreender os sentidos e significados das suas diversas manifestações na sociedade contemporânea.

Em relação à disciplina de Língua Estrangeira Moderna (LEM), importa construir um conhecimento sistêmico sobre a organização textual e sobre como e quando utilizar a linguagem em situações de comunicação. A consciência lingüística e a consciência crítica dos usos da língua estrangeira devem possibilitar o acesso a bens culturais da humanidade.

Assim, não só o estudo da língua materna mas também o das LEM são excelentes meios para sensibilizar os alunos para os mecanismos de poder associados a uma língua. 
No ensino das disciplinas da área, deve-se levar em conta, em primeiro lugar, que os alunos se apropriam mais facilmente do conhecimento quando ele é contextualizado, ou seja, quando faz sentido dentro de um encadeamento de informações, conceitos e atividades. Dados, informa¿çõos, idéias e teorias não podem ser apreSentados de maneira estanque, separados Co de sulas condições de produção, do tipo de sociedade em que são gerados e recebidos, de sua relação com outros conhecimentos. Do nosso ponto de vista, a contextualização apode se dar em três níveis:

A contextualização sincrônica, que ocorre num mesmo tempo, analisa o objeto em relação à época e à sociedade que o gerou. Quais foram as condições e as razỗes da sua produção? De que maneira ele foi recebido em sua época? Como se deu o acesso a ele? Quais as condições sociais, econômicas e culturais da sua produção e recepção? Como um mesmo objeto foi apropriado por grupos sociais diferentes?

A contextualização diacrônica, que ocorre através do tempo, considera o objeto cultural no eixo do tempo. De que maneira aquela obra, aquela idéia, aquela teoria, se inscreve na História da Cultura, da Arte e das Idéias? Como ela foi apropriada por outros autores em períodos posteriores? De que ma- neira ela se apropriou de objetos culturais de épocas anteriores a ela própria?

A contextualização interativa permite relacionar o texto com o universo específico do leitor: como esse texto é visto hoje? Que tipo de interesse ele ainda desperta? Que características desse objeto fazem com que ele ainda seja estudado, apreciado ou valorizado?

A questão da contextualização remetenos à reflexão sobre a intertextualidade e a interdisciplinaridade. De que maneira cada objeto cultural se relaciona com outros objetos culturais? Como uma mesma idéia, um mesmo sentimento, uma mesma informação são tratados pelas diferentes linguagens? Aqui nos interessam, por exemplo, as novas tecnologias de informação, o hipertexto, os CD-ROMs e as páginas da internet, mas também outras expressões artísticas, como a pintura, a escultura, a fotografia etc.

A construção do conhecimento humano e o desenvolvimento das artes, da ciência, da filosofia e da religião foram possíveis graças à linguagem, que permeia a construção de todas as atividades do homem. Não apenas a representação do mundo, da realidade física e social, mas também a formação da consciência individual e a regulação dos pensamentos e da ação - próprios ou alheios - ocorrem na e pela linguagem. 


\section{A área de Ciências Humanas e suas Tecnologias}

"Cabe às futuras gerações construir uma nova coerência que incorpore tanto os valores humanos quanto a ciência, algo que ponha fim às profecias quanto ao 'fim da ciência', 'fim da história' ou até quanto ao advento da pós-humanidade". (llya Prygogine, "Carta para as futuras gerações", Caderno Mais, Folha de S.Paulo, 30/01/2000).

A expressão "Ciências Humanas e suas Tecnologias" leva-nos a uma reflexão inicial usobre sua inserção no campo dos conhecimentos a serem oferecidos, atualmente, no conjunto da educação básica.

Embora toda ciência seja indiscutivelmentechưmana, por resultar da acumulação cultural gerada por diferentes sociedades, em diferentes tempos e espaços, o estudo das denominadas "humanidades" remonta às artes liberais antigas, notadamente ao estudo das artes, línguas e literaturas clássicas. Na Idade Média, a tradição cristã acentuou a distinção entre a literatura sacra e a profana, evidenciando o caráter laico das humanidades, e em seguida o Renascimento perpetuou esta condição, enfatizando a necessidade de um arcabouço de conhecimentos acerca dos estudos sobre o humano e sua condição moral. Para Chervel \& Compère (1999), esta tradição formou um indivíduo que, do homem honesto das idades clássicas ao homem cultivado da época contemporânea, adquiriu gosto, senso crítico, capacidade de julgamento pessoal e desenvolveu a arte de se exprimir oralmente ou por escrito. Portanto, o estudo das Humanidades, até o século XIX, foi responsável pela formação do "cristão dos colégios jesuítas, do cidadão das Luzes e do republicano dos liceus modernos".

Na primeira metade do século $X X$, as Ciências Humanas consolidaram-se como conhecimento científico, a partir das contribuições da fenomenologia, do estruturalismo e do marxismo; porém, o ensino das Humanidades, como corpo curricular tradicional e enciclopedista, dirigido à formação das elites, somente apresentou mudanças significativas nas três últimas décadas do século passado, como resultado das grandes transformações socioeconômicas, políticas e tecnológicas.

Para Mello (1998), na área de Ciências Humanas, destacam-se as competências relacionadas à apropriação dos conhecimentos dessas ciências com suas particularidades metodológicas, nas quais o exercício da indução é de importância crucial. A autora propõe, também, que o ensino de Ciências Humanas deve desenvolver a compreensão do signifi- 
cado de identidade, da sociedade e da cultura, que configuram os campos de conhecimentos das Ciências Humanas, incluindo, de modo significativo, os estudos necessários ao exercício da cidadania.

$\mathrm{Na}$ atualidade, a área de Ciências Humanas compreende conhecimentos produzidos por vários campos de pesquisa: História, ¿GGeografia, Filosofia, Sociologia e Psicologia, além de outros como Política, Antropologia e Economia, que têm por objetivo o estudo dos seres humanos em suas múltiplas relações fundamentado por meio da articulação entre estes diversos saberes. Neste sentido, a Tprodução científica, acelerada pela sociedade tecnólógica, tem colocado em debate uma gaâma variada de novas questões de natureza ética, cultural e política, que necessitam emergir como objeto de análise das disciplinas que compõem as Ciências Humanas. Portanto, o caráter interdisciplinar desta área corrobora ra necessidade de se utilizar o seu acervo de conhecimentos para auxiliar os jovens estu- dantes a compreender as questões que os afetam, bem como a tomar as decisões neste início de século. Desta forma, ao integrar os campos disciplinares, o conjunto dessas ciências contribui para uma formação que permita ao jovem estudante compreender as relações entre sociedades diferentes; analisar os inúmeros problemas da sociedade em que vive e as diversas formas de relação entre homem e natureza, refletindo sobre as inúmeras ações e contradições da sociedade em relação a si própria e ao ambiente.

\section{Referências}

CHERVEL,André; COMPÈRE, Marie-Madeleine. As humanidades no ensino. Educação e Pesquisa. FE/USP, São Paulo, v. 25, n. 2, jul.-dez., 1999.

MELLO, Guiomar N. de. Diretrizes curriculares nacionais para o ensino médio: parecer. Brasília: MEC/CNE, 1998. 


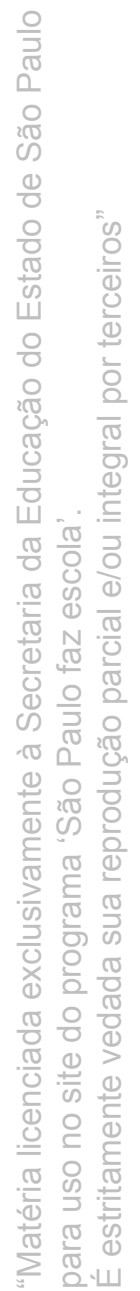




\section{Proposta Curricular do Estado de São Paulo para a disciplina de Geografia}

\section{Ensino Fundamental - Ciclo II e Ensino Médio}

"As palavras e os conceitos são vivos, escapam escorregadios como peixes entre as mãos do pensamento e como peixes movem-se ao longo do rio da História. Há quem pense que pode congelar conceitos. Essa pessoa será quando muito um colecionador de idéias mortas" (COUTO, Mia. Pensatempos).

Nos últimos vinte anos, o ensino de Geografia sofreu muitas transformações. Em uparte, este processo de renovação partiu de críticas ao ensino tradicional fundamentado ¿na memorização de fatos e conceitos e na condução de um conhecimento enciclopedista, meramente descritivo e em grande parte sem relação com a realidade. No Brasil, estas criticas, provenientes de segmentos da sociedade engajados na democratização do país, fundamentaram-se na necessidade de se estaדై do espaço geográfico, de forma a desvendar as origens e os processos de evolução dos diferentes fenômenos geográficos.

Neste período de intenso debate, a crítica ao ensino de Geografia encontrou ressonância nos órgãos técnico-pedagógicos de alguns dos Estados brasileiros, como ocorreu com a Proposta Curricular de 1996, desenvolvida pela Secretaria da Educação do Estado de São Paulo, que por meio de seus órgãos pedagógicos coordenou um processo de discussão e reformulação curricular no âmbito do Estado de São Paulo, sinalizando novos rumos.

Rompeu-se, dessa forma, o padrão de um saber supostamente neutro para uma visão da Geografia enquanto ciência social engajada e atuante num mundo cada vez mais dominado pela globalização dos mercados, pelas mudanças nas relações de trabalho e pela urgência das questões ambientais e etnoculturais. Da mesma forma, esta nova proposta de ensino procurou ir além da dicotomia sociedade-natureza, responsável por perpetuar o espaço como uma entidade cartesiana e absoluta, na qual tudo acontece de forma linear ou casuística. Além disto, relacionou os fenômenos sociais com a natureza apropriada pelos seres humanos, compreendendo as relações que se estabelecem entre os eventos sociais, culturais, econômicos e políticos em suas diferentes escalas.

Na década de 1990, o Ministério da Educação publicou os Parâmetros Curriculares Nacionais, reforçando a tendência da crítica ao ensino conteudista propondo o ensino por competências. Entretanto, em momento 
algum, o currículo por competências prescinde de conteúdos estruturadores. As competências só podem ser desenvolvidas se houver um ensino que privilegie a aprendizagem de conteúdos mediados por contextos significativos, ou por situações-problema, Trepresentativos do cotidiano do aluno. CCComo salienta Maria do Céu ROLDÃO (2004, p. 20) é possível associar o conceito de comğpetência definido por Perrenoud como um saber em uso, ao seu oposto apresentado gor Le Boterf, ou seja, um saber inerte. Muitas vezes os conhecimentos adquiridos durante a vida escolar transformam-se em saberes inertes, pois se não os utilizarmos culturalmente - como os define LéviStraüss ao criar a expressão utensílios do pensamento - não os transformaremos êm competências.

Dentre as obras acadêmicas que se tornaram referência nesse debate, destacam-se as do professor Milton Santos, que reconduziram os debates teóricos para terreunos mais férteis, estabelecendo parâmetros Seguros com relação à definição de um corToo teórico-metodológico adequado aos novos tempos. Para este autor, a "revolução" provocada pelo advento das tecnologias de comunicação e informação transformou o espaço do Homem e, necessariamente, a nossa maneira de pensar o mundo em que vivemos. Essa nova dimensão de espaço influenciou os modos de agir e pensar da humanidade como um todo. Se, por um lado, provocou mudanças nas relações pessoais, socioculturais e nas formas de se produzir e de se trabalhar, por outro, foi responsável pela acentuação das desigualdades entre povos e nações. Neste contexto, os anseios por uma sociedade mais igualitária e justa, e principalmente mais aberta a incorporar mudanças e respeitar diferenças, tornou-se mais distante.

Essa nova concepção de Geografia deve, com urgência, priorizar a discussão dos desafios impostos pelas transformações do meio técnico-científico-informacional - inserido em sala de aula e fora dela - em especial, a partir do advento da comunicação on-line, responsável por influir e modificar o local, o regional e o global simultaneamente. O filósofo Edgar MORIN (2001), em sua obra Os sete saberes necessários à Educação do Futuro, argumenta de forma brilhante que o impacto da planetarização faz com que cada parte do mundo influencie o todo que o compõe, da mesma forma como o todo está cada vez mais presente em cada uma das partes. Na era planetária, tal situação não se manifesta somente entre países e nações, mas influencia de forma decisiva cada indivíduo, que recebe e consome informações e substâncias oriundas de todo o universo, sendo, portanto, influenciado por elas. 
O encurtamento das distâncias, associado à expansão das redes de comunicação e transporte, tanto de mercadorias quanto de pessoas e informações, assim como as alterações promovidas no mundo do trabalho e pelo advento cada vez mais acelerado de novas tecnologias, permitem ia todo momento vislumbrar-se um leque de interações capazes de romper com as Goarreiras culturais aproximando lugares e umundos diferentes. Como afirma o sociólogo Anthony GIDDENS (2000): "quando a gुmagem de Nelson Mandela pode ser mais familiar para nós que o rosto de nosso vizinho-de porta, alguma coisa mudou na natưreża da experiência cotidiana".

Enfim, esta nova dimensão de espaço 2- 0 yirtual - que, de acordo com HARVEY (1996, p. 219), imprime uma compressão dố tempo-espaço de forma tão radical, influenciando inclusive a maneira como representămos o mundo para nós mesmos, deve ser prioridade para o ensino da Geografia do século XXI.

A "revolução" provocada pelo advento das tecnologias de comunicação e informação, responsáveis pelo surgimento desta nova concepção de espaço, e que representa de forma contundente uma das grandes revoluções do nosso tempo, de forma contraditória não atinge a todos igualmente. Se, por um lado, provoca mudanças nas relações pessoais, socioculturais e nas formas de se produzir e de se trabalhar, tem sido responsável pela acentuação das desigualdades entre povos e nações. Como enfatiza Tabo M'Beki, presidente da África do Sul, "existem mais linhas telefônicas na ilha de Manhattan do que em toda a África, ao sul do Saara".

Neste sentido, os anseios por uma sociedade mais igualitária e justa, e principalmente mais aberta a incorporar mudanças e respeitar diferenças, torna-se mais distante. Portanto, é fundamental incluir-se o debate destes temas em sala de aula, de modo a contribuir para uma formação crítica, ética, humanística e solidária desses jovens cidadãos. Como afirma o escritor moçambicano Mia COUTO (2004), há alguns anos, a fronteira entre os ditos civilizados e os denominados "povos indígenas" era a sua integração à cultura européia, enquanto a nova fronteira que se configura poderá ser entre "digitalizados" e "indigitalizados". Neste contexto, uma nova proposta de cidadania deve ser colocada em curso para que se promova a igualdade de direitos e a justiça social.

Os Parâmetros Curriculares Nacionais levaram em consideração estas transformações, valorizando o modo como o jovem estudante 
apreende o mundo em que vive e introduzindo novos temas no currículo da disciplina. O encurtamento das distâncias, associadas à expansão das redes de comunicação e transporte, assim como as alterações promovidas nas relações de trabalho, foram transformados em conteúdos curriculares.

Esta alteração de enfoque implica propostas educacionais que considerem a interação entre os conteúdos específicos da Geografia e as outras ciências, possibilitando ao estudante, por intermédio da mediação realizada pelo professor, ampliar sua visão de mundo por meio dé um conhecimento autônomo, abrangente e responsável.

Torna-se fundamental desenvolverse uma atitude de respeito aos saberes que estudante traz à escola, adquiridos em seu meio cultural, pois é certo que chvolve uma variada gama de discussões com temas da atualidade, como a urgência ambiental, os diferentes níveis de bem²estar das populações, as questões de Saúde pública, as políticas assistenciais, greves, desemprego, relações internacionais, conflitos de diferentes ordens e crises econômicas, entre outros.

Essas questões, presentes diariamente nas inúmeras redes de comunicação, compõem o cenário no qual os jovens vivem e atuam e devem se transformar em contextos para a discussão e a compreensão do universo que os cerca. São estas as necessidades essenciais que mobilizam formas de pensar e agir de um cidadão do século XXI, que muitas vezes é ator principal de seu tempo e, em outras, coadjuvante e observador crítico das ocorrências do planeta.

Assim como os demais componentes curriculares da educação básica, cabe ao ensino de Geografia desenvolver linguagens e princípios que permitam ao aluno ler e compreender o espaço geográfico contemporâneo como uma totalidade articulada e não apenas estudar por meio da memorização de fatos e conceitos desarticulados. Também deve priorizar a compreensão do espaço geográfico como manifestação territorial da atividade social, em todas as suas dimensões e contradições, sejam elas econômicas, políticas ou culturais.

O objeto central do ensino da Geografia reside, portanto, no estudo do espaço geográfico, abrangendo o conjunto de relações que se estabelece entre os objetos naturais e os construídos pela atividade humana, ou seja, os artefatos sociais. Neste sentido, enquanto o "tempo da natureza" é regulado por processos bioquímicos e físicos, responsáveis pela produção e interação dos objetos naturais, o "tempo histórico" responsabilizase por perpetuar as marcas acumuladas 
pela atividade humana como produtora de artefatos sociais.

O ensino de Geografia na educação básica deve priorizar o estudo do território, da paisagem e do lugar em suas diferentes escalas, rompendo com uma visão estática na qual a natureza segue o seu curso imutável e Grreal enquanto a humanidade é vista como Cuma entidade a ser estudada à parte, como ise nẵo interagisse com o meio.

O conceito de escala geográfica expressa as differentes dimensões que podem ser escolhidass para o estudo do espaço geográfico, passível dé ser abordado a partir de recortes como o lugar, à região, o território nacional ou o mundo. Nö entanto, as diferentes escalas geográficas estãô sempre inter-relacionadas: é preciso, por exemplo, considerar o mundo, a região e o terJritório nacional na análise dos fenômenos que ocorrem no lugar. Os conceitos estruturadores devem considerar as seguintes dimensões:

Território - Este termo originalmenteefoi formulado pela Biologia no século XVIII, compreendendo a área delimitada por uma espécie, na qual são desempenhadas as suas funções vitais. Incorporado posteriormente pela Geografia, ganhou contornos geopolíticos ao configurar-se como o espaço físico no qual o Estado se concretiza. Porém, ao se compreender o Estado nacional como a nação politicamente organizada, estruturada sobre uma base física, não é possível considerar-se apenas sua função política, mas também o espaço construído pela sociedade, e, portanto, a sua extensão apropriada e usada. Ao se compreender o que é o território, deve-se levar em conta toda a diversidade e complexidade de relações sociais, de convivências e diferenças culturais que se estabelecem em um mesmo espaço. Desta forma, o conteúdo político do território é expresso em diferentes escalas além do Estado-nação, como no interior das cidades onde territorialidades diferentes manifestam distintas formas de poder.

Paisagem - Distinto do senso comum, este conceito tem um caráter específico para a Geografia. A paisagem geográfica é a unidade visível do real e que incorpora todos os fatores resultantes da construção natural e social. A paisagem acumula tempos e deve ser considerada como "tudo aquilo que nós vemos, o que nossa visão alcança" ( Santos, 2001), ou seja, corresponde à manifestação de uma realidade concreta, tornando-se elemento primordial no reconhecimento do espaço geográfico. Desta forma, uma paisagem nunca pode ser destruída, pois está sempre se modificando. As paisagens devem ser consideradas como forma de um processo em contínua construção, pois, representam a aparência dos elementos construídos socialmente, e, assim, representam a essência da própria sociedade que as constrói. 
Lugar - O conceito de paisagem vincula-se fortemente ao conceito de lugar e este também se distingue do senso comum. Para a Geografia, o lugar traduz os espaços nos quais as pessoas constroem os seus laços afetivos e subjetivos, pois pertencer a um território e faZer parte de sua paisagem significa estabelecer Gaços de identidade com cada um deles. É no Gugar que cada pessoa busca suas referências Tosssoais e constrói o seu sistema de valores ¿ são estes valores que fundamentam a vida em sociedade, permitindo a cada indivíduo G्रdentificar-se como pertencente a um lugar, e, a cada lugar, manifestar os elementos que the dão uma identidade única.

Educação cartográfica - A alfabetizaçãa cartográfica deve ser entendida como um dos instrumentos indispensáveis para a formação da cidadania. Como afirma Yves Lacoste, "cartas, para quem não aprendeu a lêGas eutilizá-las, sem dúvida, não têm qualquer sentído, como não teria uma página escrita "para quem não aprendeu a ler". Portanto, uma educação que objetive a formação do cidadão consciente e autônomo deve incorToorar no currículo os fundamentos da alfabetização cartográfica.

Desta forma, a aprendizagem da Geografia na educação básica, entendida como um processo de construção da espacialidade, deve considerar os seguintes objetivos:

- Desenvolver domínios de espacialidade e deslocar-se com autonomia.

- Reconhecer princípios e leis que regem os tempos da natureza e o tempo social do espaço geográfico.

- Diferenciar e estabelecer relações dos eventos geográficos em diferentes escalas.

- Elaborar, ler e interpretar mapas e cartas.

- Distinguir os diferentes aspectos que caracterizam a paisagem.

- Estabelecer múltiplas interações entre os conceitos de paisagem, lugar e território.

- Reconhecer-se, de forma crítica, como elemento pertencente ao e transformador do espaço geográfico.

- Utilizar os conhecimentos geográficos para agir de forma ética e solidária, promovendo a consciência ambiental e o respeito à igualdade e diversidade entre todos os povos, todas as culturas e todos os indivíduos. 


\section{Proposta Curricular de Geografia}

\section{$5^{\mathrm{a}}$ Série do Ensino Fundamental}

\section{$1^{\circ}$ Bimestre}

\section{A paisagem}

- Os ritmos e ciclos da natureza: os objetos naturais

- O tempo histórico: os objetos sociais

A leitura de paisagens

\section{Escalas da Geografia}

- O mundo: as paisagens captadas pelos satélites

- OO lugar: as paisagens da janela

- Entre o mundo e o lugar $2^{\circ}$ Bimestre

\section{O mundo e suas representações}

- Exemplos de representações: arte e fotografia

- Um pouco de história da cartografia

\section{A linguagem dos mapas}

- O que é um mapa

- Os atributos dos mapas

- Mapas de base e mapas temáticos

- A cartografia e as novas tecnologias

\section{$3^{\circ}$ Bimestre}

\section{$4^{\circ}$ Bimestre}

\section{As atividades econômicas e o espaço geográfico}

- A manufatura e os circuitos da indústria

- A agropecuária e os circuitos do agronegócio

- O consumo e a sociedade de serviços

- O clima, o tempo e a vida humana 


\section{Proposta Curricular de Geografia}

\section{$\sigma^{\text {a }}$ Série do Ensino Fundamental}

$1^{\circ}$ Bimestre

Oterritório brasileiro

- A cartografia da formação territorial do Brasil

- A federação brasileira: organização política e administrativa

- O Brasil no mundo $2^{\circ}$ Bimestre

A regionalização do território brasileiro

- Critérios de divisão regional

- As regiões do IBGE, os complexos regionais e a região concentrada

\section{$3^{\circ}$ Bimestre}

\section{$4^{\circ}$ Bimestre}

Brasil: população e economia

- A população brasileira e os fluxos migratórios

- A revolução da informação e a rede de cidades

- O espaço industrial: concentração e descentralização

- O espaço agrário e a questão da terra no Brasil 


\section{Proposta Curricular de Geografia}

\section{$7^{\text {a }}$ Série do Ensino Fundamental}

$1^{\circ}$ Bimestre

Globalização em três tempos

- A geografia dos "descobrimentos"

- O espaço industrial e o encurtamento das distâncias

- A revolução tecnocientífica

\section{$2^{\circ}$ Bimestre}

\section{Produção e consumo de energia}

- As fontes e as formas de energia

- Matrizes energéticas: da lenha ao átomo

- Perspectivas energéticas

\section{$3^{\circ}$ Bimestre}

\section{$4^{\circ}$ Bimestre}

\section{A crise ambiental}

- Do Clube de Roma ao desenvolvimento sustentável

- A apropriação desigual dos recursos naturais

- Água potável: um recurso finito

- A biodiversidade ameaçada

- A poluição atmosférica e os gases do efeito estufa

\section{Geografia comparada da América}

- Peru e México: a herança précolombiana

- Brasil e Argentina: as correntes de povoamento

- Colômbia e Venezuela: entre os Andes e o Caribe

- Haiti e Cuba: as revoluções 


\section{Proposta Curricular de Geografia}

\section{$8^{\text {a }}$ Série do Ensino Fundamental}

$1^{\circ}$ Bimestre

A produção do espaço geográfico global

- Globalização e regionalização

- Os blocos econômicos supranacionais

- As doutrinas do poderio dos Estados Unidos

$3^{\circ}$ Bimestre

Geografia das populações

- Demografia e fragmentação

As migrações internacionais

- Mundo árabe e mundo islâmico $2^{\circ}$ Bimestre

\section{A nova desordem mundial}

- A Organização das Nações Unidas

- A Organização Mundial do Comércio

- O Fórum Social Mundial: um outro mundo é possível? $4^{\circ}$ Bimestre

As redes sociais

- Consumo e cidades globais

- Turismo e consumo do lugar

- As redes da ilegalidade 


\section{Proposta Curricular de Geografia}

\section{$1^{\text {a }}$ Série do Ensino Médio}

$1^{\circ}$ Bimestre

Cartografia e poder

- As projeções cartográficas

- As técnicas de sensoriamento remoto

\section{Geopolítica do mundo contemporâneo}

- A nova desordem mundial

- Conflitos regionais

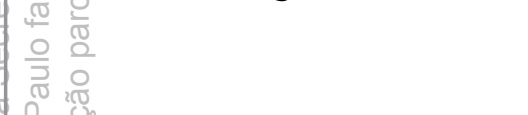

\section{$3^{\circ}$ Bimestre}

Natureza e riscos ambientais

- Estruturas e formas do planeta Terra

-Agentes internos e externos

- Riscos em um mundo desigual $2^{\circ}$ Bimestre

Os sentidos da globalização

- A aceleração dos fluxos

- Um mundo em rede

A economia global

- Organismos econômicos internacionais

- As corporações transnacionais

- Comércio internacional

\section{$4^{\circ}$ Bimestre}

\section{Globalização e urgência ambiental}

- Os biomas terrestres: clima e cobertura vegetal

- A nova escala dos impactos ambientais

- Os tratados internacionais sobre meio ambiente 


\section{Proposta Curricular de Geografia}

\section{$2^{\mathrm{a}}$ Série do Ensino Médio}

$1^{\circ}$ Bimestre

Território brasileiro

- A cartografia da gênese do território

- Do "arquipélago" ao "continente"

O Brasil no sistema internacional

- Mercados internacionais e agenda externa brasileira

$3^{\circ}$ Bimestre

Dinâmicas demográficas

- Matrizes culturais do Brasil

- A transição demográfica

\section{Dînâmicas Sociais}

- O trabalho e o mercado de trabalho

- A segregação socioespacial e exclusão social $2^{\circ}$ Bimestre

Os circuitos da produção

- O espaço industrial

- O espaço agropecuário

\section{Redes e hierarquias urbanas}

- A formação e a evolução da rede urbana brasileira

- A revolução da informação e as cidades

\section{$4^{\circ}$ Bimestre}

Recursos naturais e gestão do território

- A placa tectônica sul-americana e o modelado do relevo brasileiro

- Os domínios morfoclimáticos e bacias hidrográficas

- Gestão pública dos recursos naturais 


\section{Proposta Curricular de Geografia}

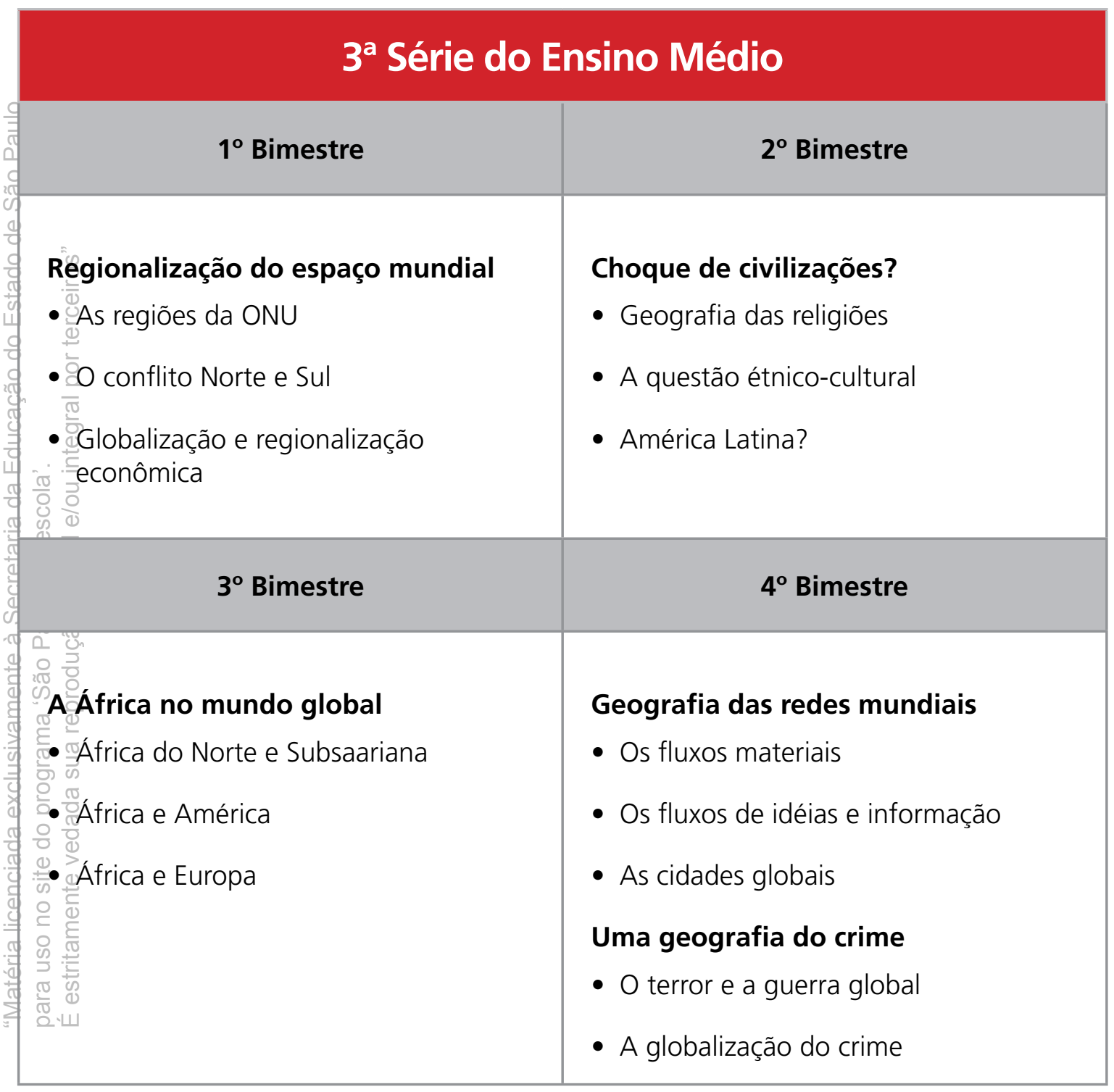




\section{Bibliografia}

COUTO, Mia. Pensatempos. Lisboa: Editorial Caminho, 2004.

GIDDENS, Anthony. Mundo em descontrole. Rio de Janeiro: Record, 2000.

HARVEY, David. Condição pós-moderna. São Paulo: Edições Loyola, 1996.

Espaços de esperança. São Păulo: Edições Loyola, 2005.

LAVOSTE, Yves. A geografia - Isso serve em primeiro lugar para fazer a guerra. Campinas, SP: Papirus, 1993.

MORAES, Antonio Carlos Robert. Geografia Pequena história crítica, $19^{a}$ ed. São Paulo: Annablume, 2003.

MORIN, Edgar. Os sete saberes necessários à educação do futuro. São Paulo: Cortez, 2001 .

PEREIRA, Diamantino. "Paisagens, lugares e Oespaços: a geografia no ensino básico". Boletim Paulista de Geografia, São Paulo, ni 79, 2003.

ROLLÃ̃o, M. do Céu. Gestão do currículo e avaliação de competências. Lisboa: Presença, 2003.

SANTOS, Milton. A natureza do espaço. São Paulo: Hucitec, 1996.

SODRÉ, Nelson W. Introdução à geografia. Rio de Janeiro: Vozes, 1985.

\section{Publicações oficiais}

BRASIL. Matriz de Referência do SAEB. Documento básico. Brasília, DF: Ministério da Educação, 1996.

BRASIL. Exame Nacional do Ensino Médio. Documento básico. Brasília, DF: Ministério da Educação, 2002.

BRASIL. Exame Nacional do Ensino Médio. Eixos cognitivos do Enem. Brasília, DF: Ministério da Educação, 2002.

BRASIL. Exame Nacional do Ensino Médio. Eixos teóricos que estruturam o Enem: conceitos principais interdisciplinaridade e contextuação. Brasília, DF: 1999.

BRASIL. Parâmetros Curriculares Nacionais. Geografia. Ministério da Educação, Brasília, DF: 2002.

SÃO PAULO. Proposta Curricular para o ensino de Geografia. Ensino fundamental Secretaria da Educação. Coordenadoria de Estudos e Normas Pedagógicas. São Paulo, 1997.

SÃO PAULO. Proposta Curricular para o ensino de Geografia. Ensino médio. Secretaria da Educação. Coordenadoria de Estudos e Normas Pedagógicas. São Paulo, 1997. 
Anotaçães

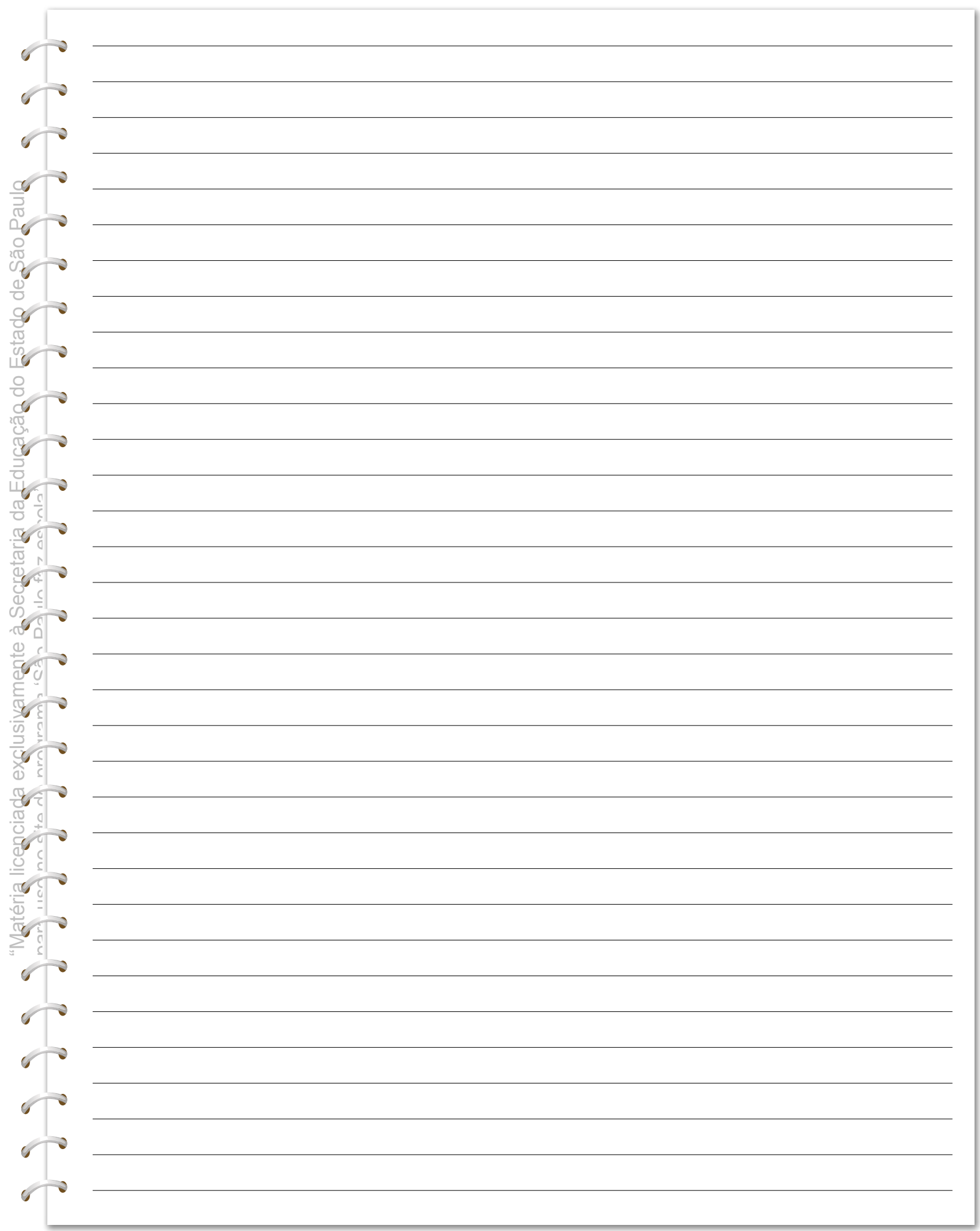


Anotaçães

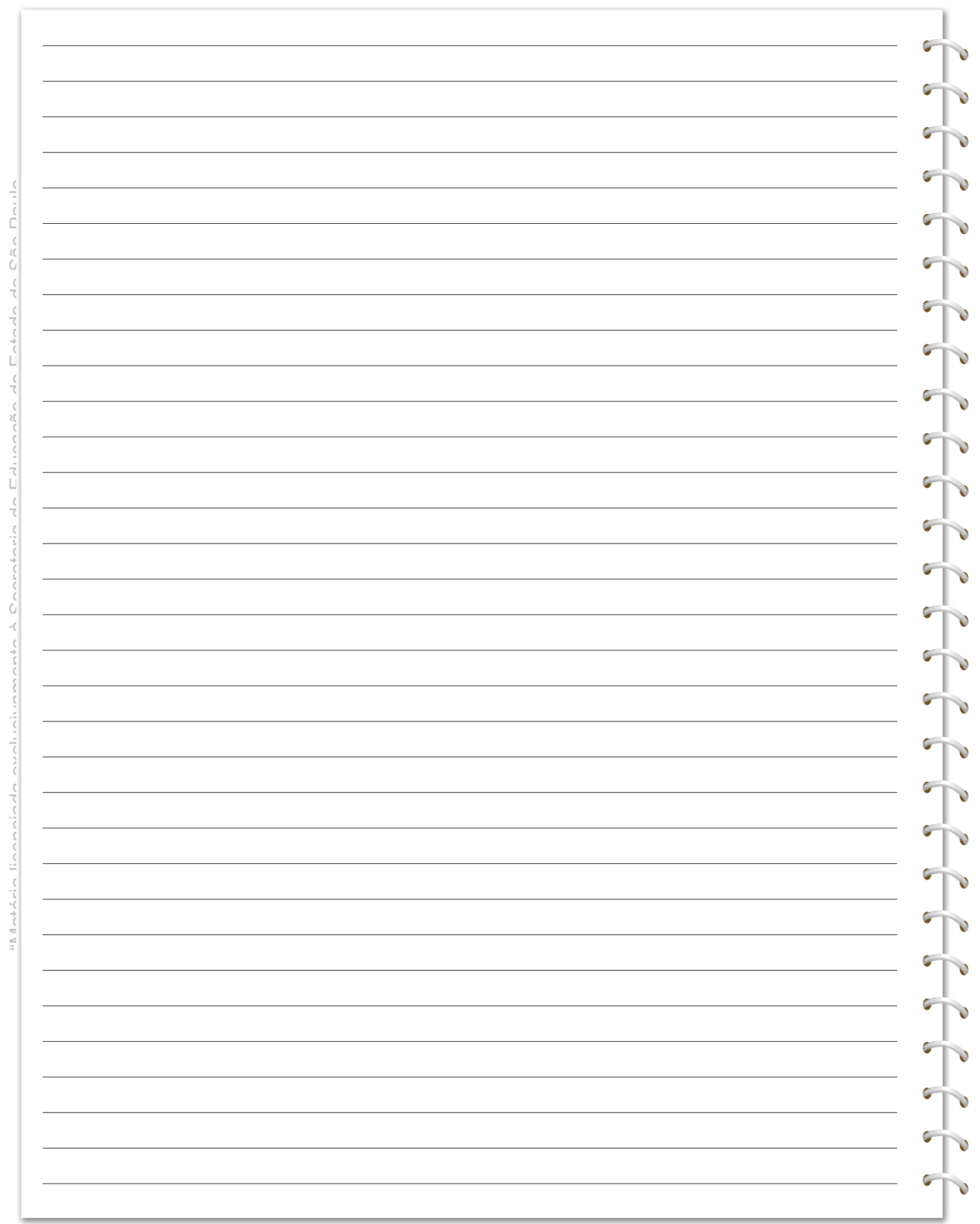

